Somosi Ágnes:

A SZOLGÁLTATÁSKIVEZETÉS HATÁSA AZ ÜGYFELEKRE A TELEKOMMUNIKÁCIÓS SZEKTORBAN 
Marketing Tanszék

Témavezető:

Dr. Kolos Krisztina

(C) Somosi Ágnes, 2017 


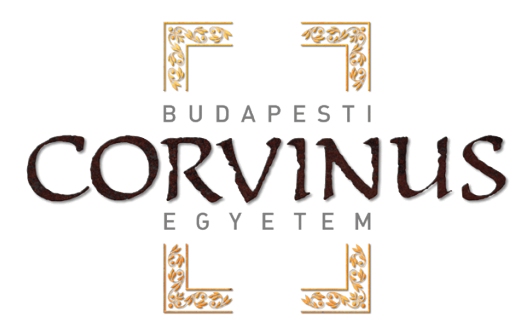

Budapesti Corvinus Egyetem

Gazdálkodástani Doktori Iskola

\section{A SZOLGÁLTATÁSKIVEZETÉS HATÁSA AZ ÜGYFELEKRE A TELEKOMMUNIKÁCIÓS SZEKTORBAN}

Doktori értekezés

Somosi Ágnes 



\section{TARTALOMJEGYZÉK}

1 BEVEZETÉS

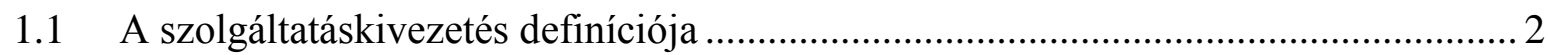

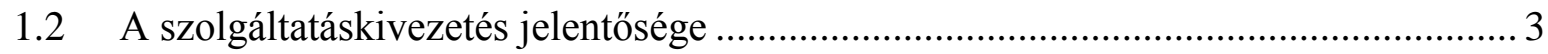

1.3 A tanulmány kontextusa: a telekommunikációs szektor......................................... 6

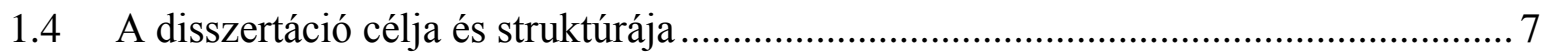

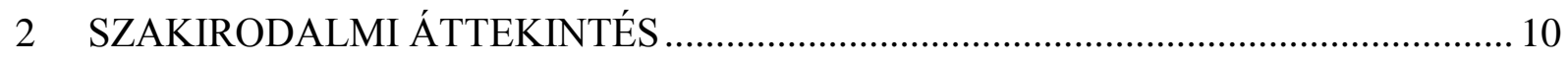

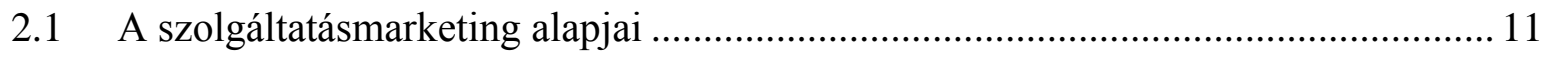

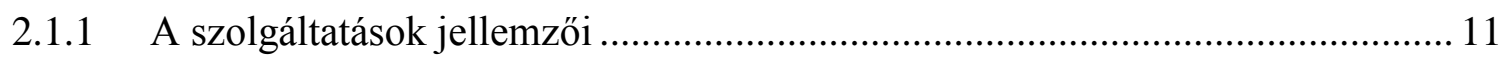

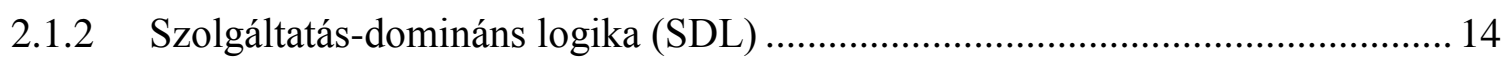

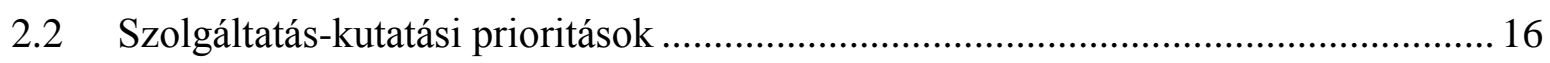

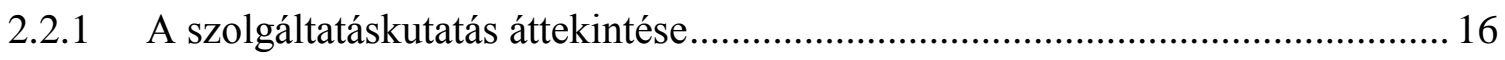

2.2.2 A szolgáltatáskivezetés kapcsolata a főbb kutatási prioritásokkal..................... 19

2.2.3 A magyar szolgáltatáskutatás trendjei 1992-2016 között ..................................2 24

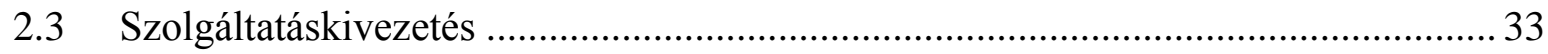

2.3.1 A termékkivezetés és szolgáltatáskivezetés közti különbségek........................ 34

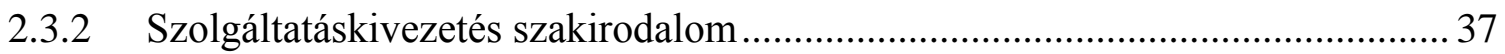

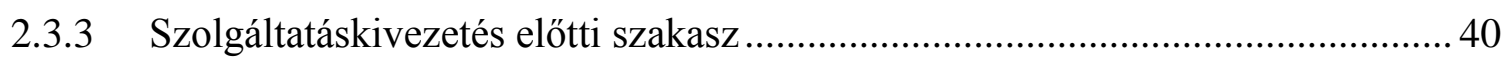

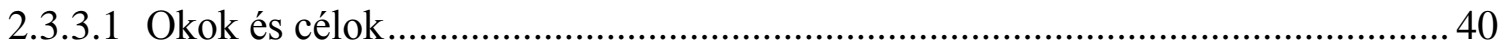

2.3.3.2 A szolgáltatáskivezetés döntési folyamata................................................. 41

2.3.3.3 A szolgáltatáskivezetés mozgatórugói ......................................................... 41

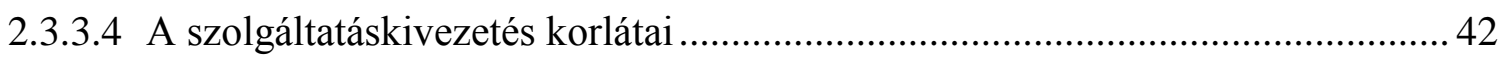

2.3.4 A szolgáltatáskivezetés implementációja .................................................... 42

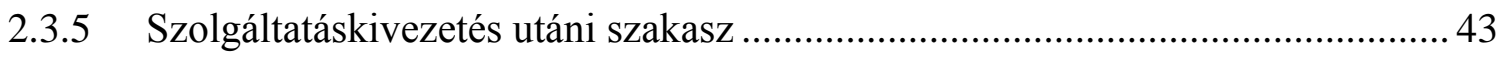

2.3.5.1 A szolgáltatáskivezetés ügyfelekre gyakorolt hatása......................................... 44

2.3.5.2 A szolgáltatáskivezetés vállalatra gyakorolt hatása ....................................... 52 
2.3.6 A szolgáltatáskivezetés ügyfelekre gyakorolt hatását magyarázó elméletek...... 52

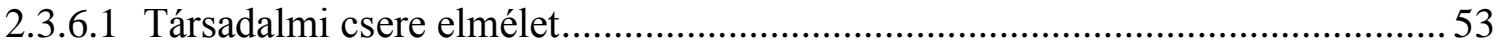

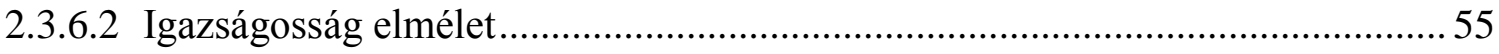

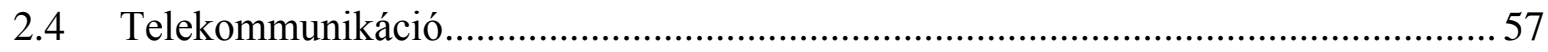

2.4.1 A telekommunikációs piac szerkezete a közép-európai régióban ......................59

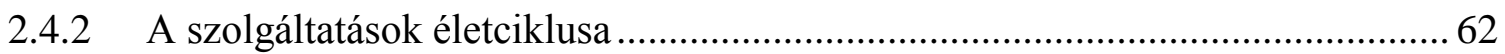

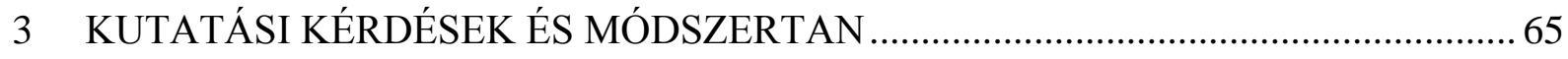

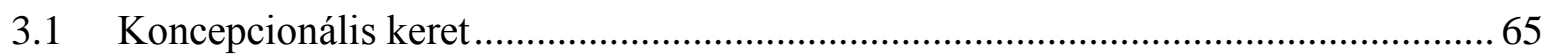

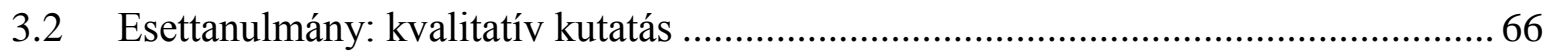

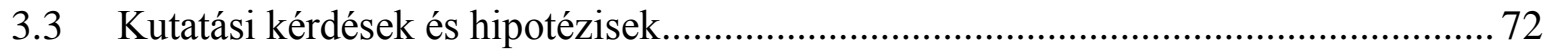

3.3.1 1. tanulmány: Kísérleti módszertan: A szolgáltatáskivezetés kimenetelét meghatározó szolgáltatáskivezetési ügyfélreakciók a társadalmi csere elmélet alapján.. 73

3.3.2 2. tanulmány: Kísérleti módszertan: A szolgáltatáskivezetés kimenetelét meghatározó szolgáltatáskivezetési ügyfélreakciók az igazságosság elmélet alapján..... 74

3.3.3 3. tanulmány: Adatbázis elemzés: Az ügyfél és szolgáltatáskivezetés tulajdonságainak szolgáltatáskivezetés kimenetére és szolgáltatáskivezetést követő

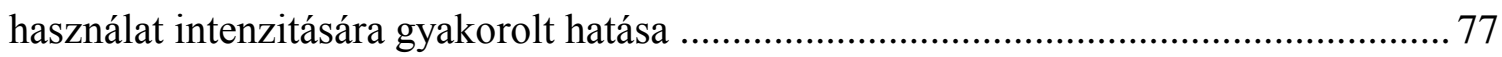

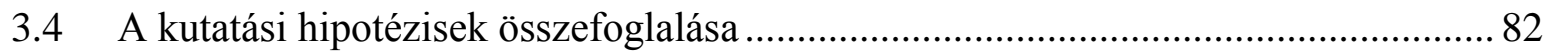

4 KUTATÁSI EREDMÉNYEK: MÉRÉS ÉS ELEMZÉS …........................................... 84

4.1 1. tanulmány: Kísérleti módszertan: A szolgáltatáskivezetés kimenetelét meghatározó szolgáltatáskivezetési ügyfélreakciók a társadalmi csere elmélet alapján...... 85

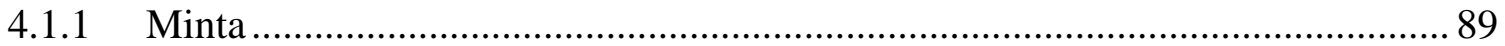

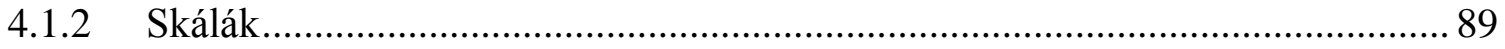

4.1.3 Belső és külső érvényesség tesztelése ........................................................... 90

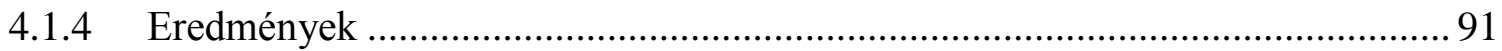

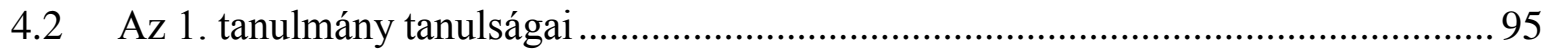

4.3 2. tanulmány: Kísérleti módszertan: A szolgáltatáskivezetés kimenetelét meghatározó szolgáltatáskivezetési ügyfélreakciók az igazságosság elmélet alapján.........96 


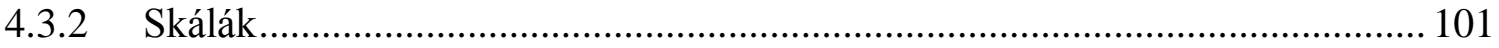

4.3.3 Belső és külső érvényesség tesztelése............................................................. 102

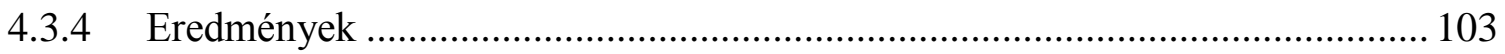

4.4 3. tanulmány: Adatbázis elemzés: Az ügyfél és szolgáltatáskivezetés tulajdonságainak A szolgáltatáskivezetés kimenetelére és a szolgáltatáskivezetést követő

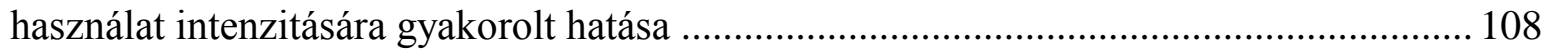

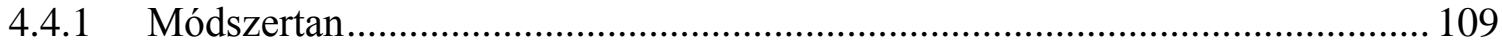

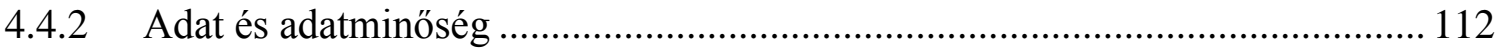

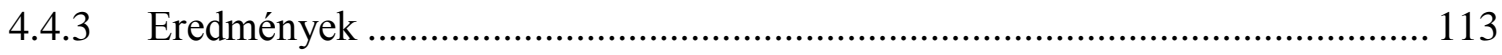

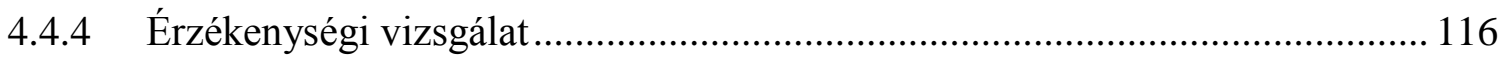

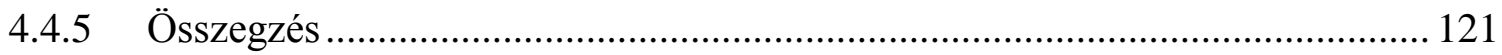

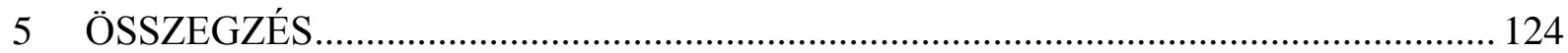

5.1 A kutatási hipotézisek értékelése ….................................................................. 128

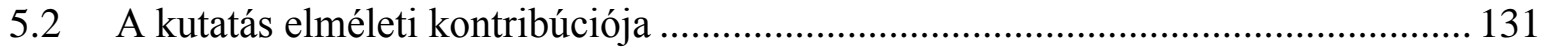

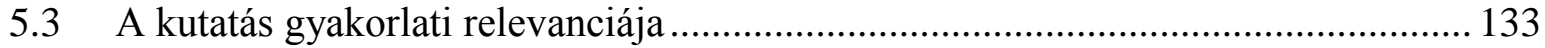

5.3.1 A szolgáltatáskivezetés esetén jelentkező lemorzsolódás a jelenleginél kedvezőbb ajánlattal és megfelelő minőségü interakcióval csökkenthető

5.3.2 A szolgáltatótól kapott kedvezőtlenebb ajánlat részben kompenzálható a folyamat során észlelt interakció minőségével.

5.3.3 Az áremelkedés növeli az ügyfél használatának intenzitását szolgáltatáskivezetést követően.

5.4 Az eredmények gyakorlati alkalmazhatósága .................................................. 136

5.5 A kutatás korlátai és jövőbeni lehetséges kutatási irányok ................................... 137

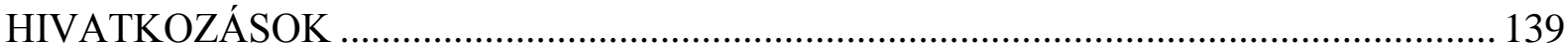

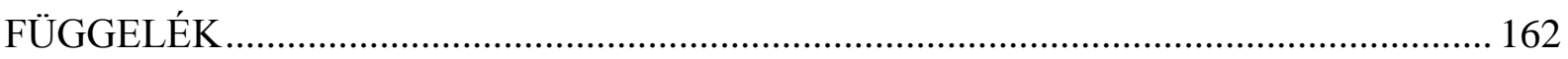

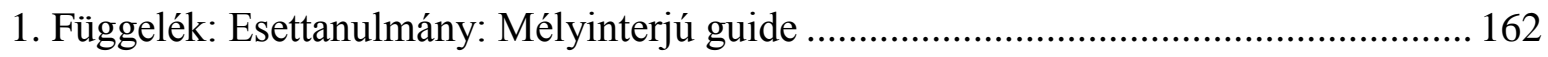

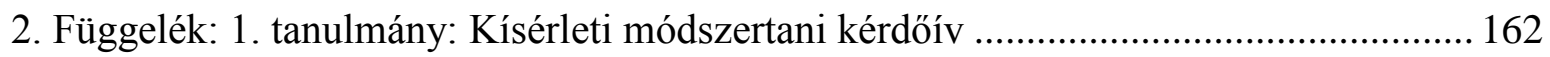


3. Függelék: 1. tanulmány: Belső és külső érvényesség kérdőíve ................................... 164

4. Függelék: 2. tanulmány: Kísérleti módszertani kérdőív ............................................ 166

5. Függelék: 2. tanulmány: Belső és külső érvényesség kérdőíve ……............................ 171

6. Függelék: 3. tanulmány: A Heckman- féle korrekciós eljárás ..................................... 176

7. Függelék: 3. tanulmány: Multikollinearitás vizsgálata- lineáris regressziós modell ..... 177

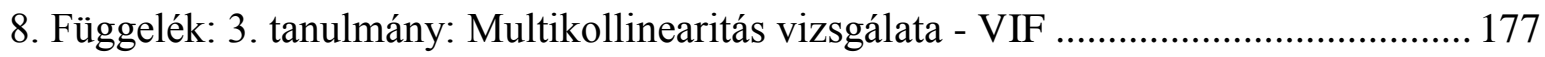

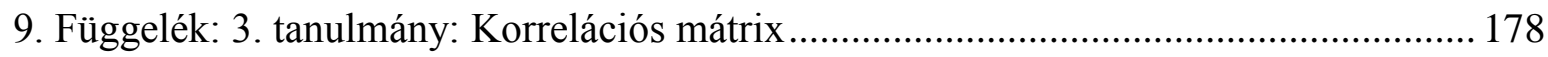

10. Függelék: 3. tanulmány: $\mathrm{R}^{2}$ becsléséhez készített csak konstanst tartalmazó modell . 178 11. Függelék: 3. tanulmány: Backward eljárással manuálisan készített modell utolsó

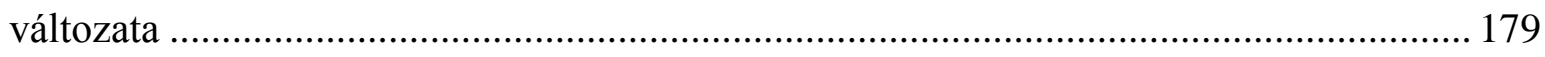

A SZERZŐ TÉMÁBAN MEGJELENT PUBLIKÁCIÓI ................................................... 181 


\section{Ábrák jegyzéke}

1. ábra: Szolgáltatáskínálat menedzsment és befolyásoló tényezői ........................................ 3

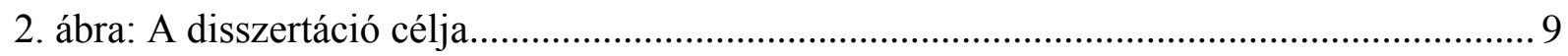

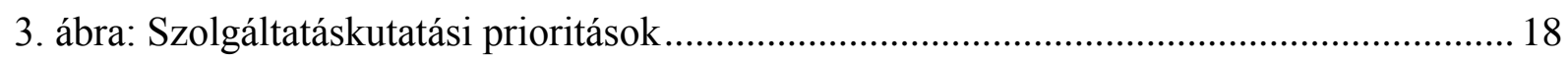

4. ábra: A Marketing \& Menedzsment és Vezetéstudomány szolgáltatás témájú cikkeinek

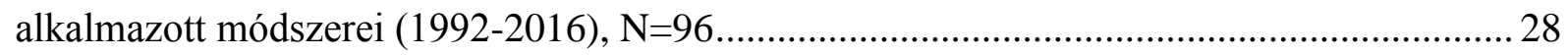

5. ábra: A Marketing \& Menedzsment és Vezetéstudomány szolgáltatás témájú cikkeinek alkalmazott módszerei, fö témák szerinti csoportosításban (1992-2016), N=96 .................... 29

6. ábra: A Marketing \& Menedzsment és Vezetéstudomány szolgáltatás témájú cikkeinek áttekintése a 3 fő korszakban, fó témák szerint (1992-2016), N=96…….............................. 31

7. ábra: A panaszt követő viselkedés meta-analitikus kerete .................................................. 57

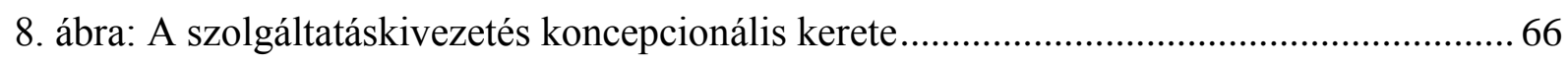

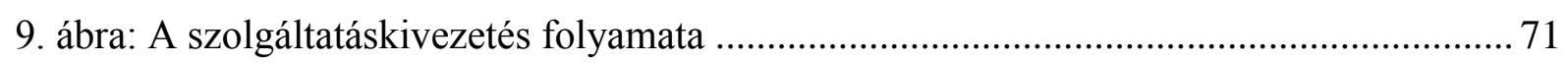

10. ábra: A szolgáltatáskivezetés koncepcionális kerete hipotézisekkel kiegészítve............... 82

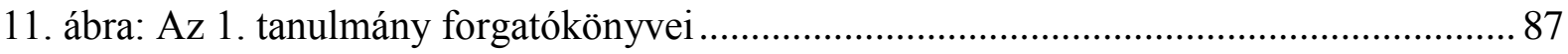

12. ábra: A gazdasági és pszichológiai költségek interakciói ............................................... 93

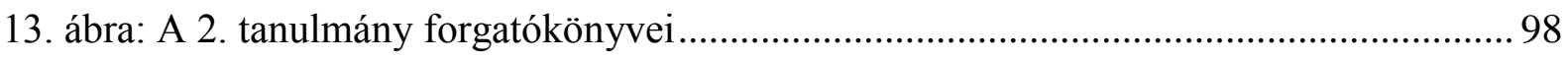

14. ábra: A disztributív, procedurális és interakciós igazságosság interakciói ...................... 106

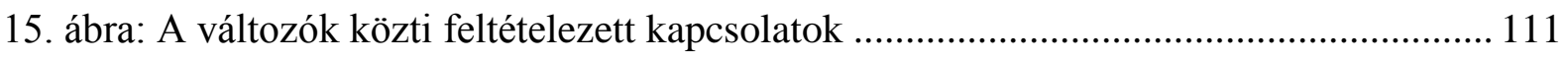

\section{Táblázatok jegyzéke}

1. táblázat: A szolgáltatáskivezetés kapcsolata a szolgáltatáskutatási prioritásokkal ..............20

2. táblázat: A Marketing \& Menedzsment és Vezetéstudomány szolgáltatás témájú cikkeinek

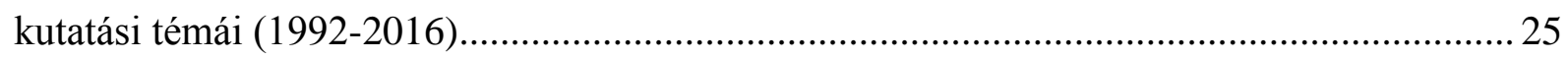

3. táblázat: A szolgáltatáskivezetés és termékkivezetés közti............................................... 36

4. táblázat: A szolgáltatáskivezetés szakirodalom összegzése............................................. 38

5. táblázat: A közép-kelet-európai vállalatok mobil telekommunikációs .............................. 61

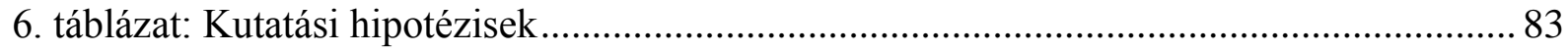

7. táblázat: A függő változók átlagértékei a független változók szerint képzett csoportokban (a szignifikáns átlagértékek vastag kiemeléssel szerepelnek)

8. táblázat: A függő változók átlagértékei a független változók szerint képzett csoportokban (a szignifikáns átlagértékek vastag kiemeléssel szerepelnek) 104 
9. táblázat: A Heckman- féle korrekciós modell eredményei: 1. modell $(\mathrm{N}=7766$, a szignifikáns értékek vastag kiemeléssel szerepelnek)

10. táblázat: A Heckman- féle korrekciós modell eredményei: 2. modell $(\mathrm{N}=8647$, a szignifikáns értékek vastag kiemeléssel szerepelnek)

11. táblázat: A Heckman- féle korrekciós modell eredményei robusztus standard hibával: 1 . modell ( $\mathrm{N}=7766$, a szignifikáns értékek vastag kiemeléssel szerepelnek)

12. táblázat: A Heckman- féle korrekciós modell eredményei robusztus standard hibával: 2. modell ( $\mathrm{N}=8647$, a szignifikáns értékek vastag kiemeléssel szerepelnek) 120

13. táblázat: A kutatási módszertan összegzése 126

14. táblázat: A kutatási hipotézisek összegzése 129 


\section{Köszönetnyilvánítás}

Disszertációm megírásában sokan voltak segítségemre. Először is témavezetőmnek, Kolos Krisztinának szeretném megköszönni a végtelenül kitartó támogatását és a kutatásom minden pontján nyújtott segítségét. Nélküle nem lettem volna képes ilyen ütemben haladni a kutatással, és nem juthattam volna el idáig, ezúton is hálásan köszönöm neki.

Berács Józsefnek köszönöm vezetői támogatását, a doktori folyamat különböző szakaszaiban nyújtott segítségét, bármikor fordulhattam hozzá, köszönöm neki.

Édesanyám és édesapám mindig támogattak abban, hogy bármi is érdekelt, abban elmélyedhessek. A doktori folyamat során is mindvégig mellettem álltak, és ösztönöztek arra, hogy minden akadályt le tudjak küzdeni. Hálás vagyok Nektek, köszönöm, hogy hisztek bennem. Köszönöm a családom támogatását, nélkülük képtelen lettem volna idáig eljutni.

Szeretném megköszönni a Bécsi Közgazdaságtudományi Egyetem (WU) munkatársainak a támogatását, kiemelten Alfred Stiassny Heckman- féle korrekciós eljárással kapcsolatos segítségét.

Volt tanáraim és azóta már munkatársaim közül szeretném kiemelni Neulinger Ágnes segítségét, különösen még a doktori folyamat kezdetén, aki nélkül nem lehetett volna sikeres a felvételim. Megtisztelő a támogatása, ahogy végigkísérte pályafutásomat azóta is, köszönöm neki.

Szeretném megköszönni Döbrőssy Gábor és Balogh Tibold segítségét a Vodafone Magyarország részéről.

Szeretném megköszönni továbbá a Marketing és Média Intézet kollégáinak, munkatársainak a segítségét, munkatársaim közül Gáti Mirkót szeretném kiemelni, aki a doktori előrehaladásomat végigkísérve szakmailag támogatott, bármikor fordulhattam hozzá, ezúton is köszönöm neki. Köszönöm a Gazdálkodástudományi Doktori Iskola kollégáinak, munkatársainak a segítségét, kiemelten Zsóka Ágnes támogatását.

Kenesei Zsófia és Bauer András vezetői támogatásukkal rengeteg ponton segítettek továbbhaladni, nagyon jó érzés volt a folyamat során, hogy számíthatok rájuk bármilyen probléma esetén. Hálásan köszönöm nekik. 


\section{BEVEZETÉS}

„A jövö nem elöttünk van.

Már megtörtént."

(Philip Kotler)

A szolgáltatáskivezetés a portfólió megújításának lehetséges eszköze, hiszen lehetővé teszi a szolgáltatóvállalatok erőforrásainak felszabadítását, és ezáltal gyorsítja az új szolgáltatások bevezetését. A szolgáltatások rövid életciklusa miatt a szolgáltatások nagyon hamar feltorlódnak a vállalatok rendszereiben, amely egy viszonylag nagy szolgáltatásportfólió menedzselését teszi szükségessé. A mai gyorsan változó gazdasági körülmények között a szolgáltatáskivezetés a versenyképesség és innováció feltételének tekinthető, hiszen az üzleti portfolió egyszerüsítésével az ügyfél és vállalati érték egyaránt növelhetőek.

A téma gyakorlati relevanciája ellenére a szolgáltatáskivezetés meglehetősen elhanyagolt terület a szakirodalomban, hiszen a vállalatok az 1980-as évektől kezdődően a szolgáltatásfejlesztésre fókuszáltak, amely az ilyen témájú kutatásokat helyezte előtérbe. Ez a folyamat azonban összetett szolgáltatásportfóliók kialakulásához vezetett, amelyeket a meglévő szolgáltatások kivezetésével lehetne egyszerűsíteni, ezáltal a fenntartási költségek is csökkenthetőek és a portfólió teljesítményének menedzselése is megkönnyíthető. Mindezek alapján a szolgáltatáskivezetés területén új felfedezések tárhatóak fel.

Egy kiemelten fontos terület a szolgáltatáskivezetés hatása az ügyfelekre, mind akadémiai, mind pedig gyakorlati oldalról. Szisztematikus tervezés és végrehajtás nélkül a szolgáltatáskivezetés lemorzsolódáshoz vezethet. A szolgáltatók számára a szolgáltatáskivezetést követő lemorzsolódás minimalizálása kihívást jelent, amely egyrészt stratégiai megfontolásokra, másrészt a folyamatról limitáltan elérhető információkra vezethetőek vissza.

Kutatásunk középpontjában a szolgáltatáskivezetés ügyfélreakciói állnak, mivel a szolgáltatáskivezetés folyamata önmagában hordozza a meglévő ügyfelek elvesztésének és a bevétel csökkenésének kockázatát. Kutatásunk célja tehát a szolgáltatáskivezetést követő ügyfélreakciók minél pontosabb megértése, amely összességében meghatározza a szolgáltatáskivezetés sikerességét.

Mivel a szolgáltatáskivezetés szorosan kapcsolódik a lemorzsolódás csökkentéséhez és az ügyfélelégedettséghez, a szakirodalomban három fó irányt követünk: a 
szolgáltatáskivezetés és termékkivezetés közti különbségeket, a szolgáltatáskivezetést (a szolgáltatáskivezetés előtti szakaszt, a szolgáltatáskivezetés implementációját, és a szolgáltatáskivezetést követő szakaszt) és a szolgáltatáskivezetés ügyfelekre gyakorolt hatását magyarázó elméleteket (társadalmi csere elmélet, igazságosság elmélet) vizsgáljuk.

\subsection{A SZOLGÁLTATÁSKIVEZETÉS DEFINÍCIÓJA}

A fő fogalmak definiálása elengedhetetlen a szolgáltatáskivezetés szakirodalmához való hozzájárulás érdekében, ezért először áttekintjük a szakirodalomban jelenleg elérhető szolgáltatáskivezetés definíciókat, majd megalkotjuk saját definíciónkat, amelyet a disszertáció során alkalmazunk.

Gounaris és szerzőtársai (2006) úgy határozzák meg a szolgáltatáskivezetést, mint a szolgáltatóvállalatok azon tevékenységét, amely mind a meglévő szolgáltatások lezárását, mind pedig azok kivezetését egyaránt magába foglalja.

Argouslidis (2006) a szolgáltatáskivezetést összevonásként vagy racionalizálásként definiálja, amely azokra a stratégiai döntésekre vonatkozik, amelyek során kivezetnek egy szolgáltatást, vagy a meglévőt egy új, továbbfejlesztett szolgáltatással helyettesítik. Ez a fajta meghatározás közelebb áll a szolgáltatásportfólió menedzsmenthez, vagy vállalati portfólió menedzsmenthez (corporate portfolio management, CPM), amely másfelöl az innovációhoz is kapcsolódik, hiszen a szolgáltatáskivezetés felgyorsítja az innováció folyamatát.

Argouslidis (2001) a szolgáltatáskivezetést és a szolgáltatásfejlesztést a szolgáltatáskínálat menedzsment (service range management) részeként definiálja (1. ábra). A szolgáltatáskínálat menedzsment tevékenységeit a vevők, a versenytársak, a vállalat jellemzői, céljai és erőforrásai, valamint a politikai, gazdasági, társadalmi és technológiai környezet befolyásolják. Ez a megközelítés összekapcsolja a szolgáltatásfejlesztést-és kivezetést, hiszen a termékek/szolgáltatások kivezetése által a továbbfejlesztett termékek/szolgáltatások megújulnak (Crowley, 2017). A termék- vagy szolgáltatáskivezetés a folyamatinnovációkhoz áll közelebb, a termék- vagy szolgáltatás- innovációval összehasonlítva (Crowley, 2017). A megszüntetés azt jelenti, hogy „a vállalat egy fö termék vagy szolgáltatás vonalat megszüntetett az elmúlt 3 évben” (Crowley, 2017, 256. o.). 


\section{1. ábra: A szolgáltatáskínálat menedzsment és befolyásoló tényezői}

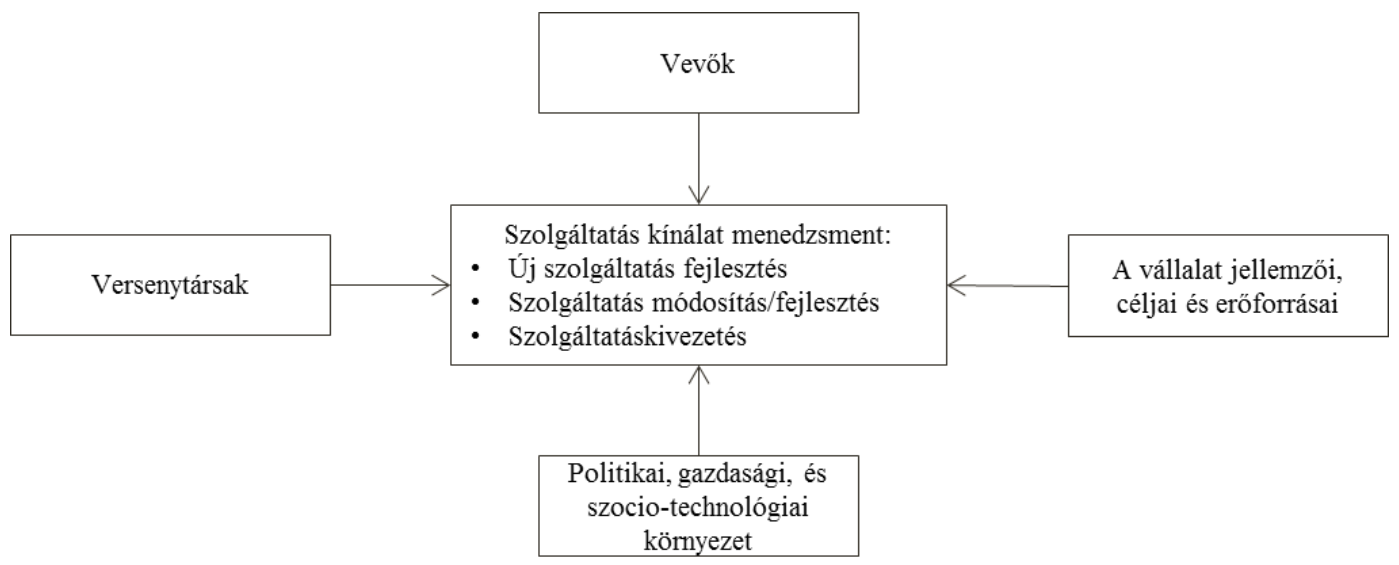

Forrás: Argouslidis (2001: 34. o.)

Argouslidis (2001) a kivezetés három típusát különbözteti meg: lezárás, a meglévő szolgáltatások kivezetése, és bizonyos ügyfélszegmensektől való lezárás, de „operacionalizálásként” hivatkozik ezekre a formákra. Emellett a részleges kivezetési stratégiákra is felhívja a figyelmet, mint például a szolgáltatás lezárás, egyszerüsítés vagy szolgáltatás összeolvasztás, stb. A szolgáltatás lezárása lehetővé teszi a jelenlegi ügyfelek számára a szolgáltatás további igénybevételét, hiszen csak új ügyfelek számára nem lesz elérhető a továbbiakban a szolgáltatás. Szolgáltatáskivezetés esetén mind a meglevő, mind az új ügyfelek számára megszünik a szolgáltatás. A szolgáltatáskivezetés típusát tekintve lehet önkéntes, illetve kényszerített, attól függően, hogy az ügyfél önként választ új előfizetést a megszünő helyett vagy a szolgáltató kényszeríti a váltást. Ez erősen befolyásolja az ügyfélmegtartást.

Annak ellenére, hogy a teljes kivezetés lehetséges, a legtöbb vállalat csak abban az esetben alkalmazza ezt a formát, ha a jogi feltételekben történt változás. Ehhez hasonlóan Harness és Mackay (1997) ezt a fajta kivezetést „fő termék” kivezetésnek hívják, amely egy összetett és kockázatos stratégia.

A szakirodalom alapján megalkotjuk saját szolgáltatáskivezetés definíciónkat, amelyet kutatásunk során használunk: a szolgáltatáskivezetés egy olyan folyamat, amelynek során a szolgáltatóvállalat kivezeti meglevő szolgáltatásait úgy, hogy szerződött ügyfeleit új szolgáltatáscsomagokra irányítja át.

\subsection{A SZOLGALTATÁSKIVEZETÉS JELENTŐSÉGE}

A szolgáltatáskivezetés relevanciája magyarázatra szorul, hiszen meglehetősen alulkutatott területről van szó. Úgy gondoljuk, hogy a szolgáltatáskivezetés az innováció egyik forrása lehet, és a vállalatok számára rengeteg feltáratlan területen nyújthat versenyelőnyt. 
A szolgáltatáskivezetés a vállalatok számára egy különleges terület, hiszen a szolgáltatásfejlesztéshez képest eltérö ügyfélreakciókat vált ki. Ez alapjaiban meghatározza a vállalatok stratégiájának kialakítását, habár jelentősége sok esetben még nem felismert. Ahogyan a teljes szolgáltatáskivezetési folyamat érinti az ügyfeleket, erősen befolyásolja a vállalatok bevételeit is.

A szolgáltatáskivezetés számos szolgáltató iparágban vált lényeges kérdéssé (Avlonitis \& Argouslidis, 2012), ennek ellenére a szolgáltatáskivezetés még mindig az egyik legkevésbé kutatott terület a szolgáltatásmenedzsment szakirodalomban. Noha a termékkivezetésnek jelentős irodalmi háttere van, a termékkivezetés elméleti alapjai nem alkalmazhatóak teljes egészében a szolgáltatások esetében. Ezért további kutatás szükséges a kérdés vizsgálatára.

A szolgáltatáskivezetés és az új szolgáltatások közötti kapcsolat világos, Ennew (1995) így fogalmaz: „A termékek túlzott elburjánzása túlságosan hosszú szolgáltatási láncok kialakulását eredményezheti, amely zavart kelt az ügyfelek számára. Ennek eredményeképpen, minden terméklánc kiterjesztő müvelet során (line stretching exercise) a vállalatnak nemcsak új vonalak hozzáadását, hanem a meglévö vonalak racionalizálását is meg kellene fontolnia." (Ennew, 1995, 107. o.). Vagyis kölcsönös függöség van a két fogalom között (Argouslidis, 2001).

Argouslidis (2001) amellett érvel, hogy a szolgáltatáskivezetés már nem a visszaesés vagy stagnálás forrása a pénzügyi szektorban, hanem a szolgáltatásportfólió kiterjesztése és racionalizálása szükséges, a kiterjesztés megnövelt hatékonyságával. Emellett a felsővezetés attitüdjének megváltoztatására is felhívja a figyelmet. A versenyhelyzetből adódó nyomás, a jogi környezetben történt változások, a technológiai fejlesztések, vagy ezek kombinációja felgyorsíthatják a szolgáltatáskivezetésre való igényt.

Emellett a szolgáltatáskivezetési döntési folyamat során alkalmazott formalizálás iránti igényre és a kivezetés utáni felülvizsgálatoknak szentelt nagyobb figyelemre is rávilágít. A legtöbb esetben az a fó probléma, hogy a kivezetés csupán részleges, ezáltal a folyamatot nem lehet lezárni az implementációt követően. A jobban szervezett kivezetés utáni felülvizsgálatok által a szolgáltatások újbóli bevezetése is proaktívabb lehet.

Annak ellenére, hogy eredményei a pénzügyi intézmények esetében érvényesek, úgy gondoljuk, hogy az eredmények relevanciáját a telekommunikációs szektorban is tesztelnünk kell. A szolgáltatáskivezetésnek nemcsak néhány szektorra kellene kiterjednie, hanem egy átfogó képet kellene nyújtania az üzleti életről. Az iparágak között eltérések tapasztalhatóak, ezért az általánosítás kizárólag megfontolt döntés eredménye lehet (Lovelock, 1983). 
Másfelől a szolgáltatáskivezetés menedzselése kihívást jelent a gyakorlatban számos területen, a telekommunikációt is beleértve (Somosi \& Kolos, 2014). A menedzserek hajlamosak megfeledkezni a meglévő szolgáltatásokról és kizárólag az újakra fókuszálnak, amely az alkalmazottak számára többletmunkával, emellett pedig a költségek növekedésével is jár, ennek eredményeképpen a folyamatokkal kapcsolatos időráfordítás is megnő (Palmer, 1998).

A szolgáltatáskivezetés folyamata kockázatos, az ügyfelek új szolgáltatáscsomagokra való átirányítása miatt, mivel ennek következtében az ügyfél gyakran vált szolgáltatót. A szolgáltatóváltás a meglévő szolgáltató másokkal való helyettesítését jelenti (Holland, 1984; Carpenter \& Lehmann, 1985; Kasper, 1988; Reichheld \& Sasser Jr, 1989; Yi, 1990; Bucklin \& Srinivasan, 1991; Keaveney, 1995). A váltás költségekkel jár, azaz „azt az egyszeri költséget foglalja magában, amelyet az ügyfelek a szolgáltató váltásával társítanak” (Burnham et al., 2003, 110. o.). Ez a költség magában foglalja az időt, pénzt és pszichológiai költségeket egyaránt (Dick \& Basu, 1994).

A szolgáltatási szektorban a váltási költségek nagyban befolyásolják a vevőlojalitást, mivel a vállalatok rendszerint az ügyfelek megtartása érdekében alkalmazzák őket. A szolgáltatóváltás, vevőlojalitás és az ügyfélmegtartás összekapcsolódó fogalmak, habár a váltás egy negatív, míg a vevőlojalitás egy pozitív eredményre utal (Bansal \& Taylor, 1999).

A magasabb váltási költségek és lojalitás között pozitív kapcsolat áll fenn (Ping, 1993; Ping, 1997; Caruana, 2004; Kim et al., 2004; Aydin \& Özer, 2005). Ezt részben az is magyarázza, hogy ez a stratégia olyan szektorokra jellemző, ahol az akvizíció során az ügyfél számos kedvezményben részesül. A szerződés hüségidő előtti felbontása az ügyfeleket ilyenkor kötbérfizetési kötelezettség terheli, amely a szolgáltatóváltást nagyban megnehezíti az ügyfelek számára, és ezáltal a vállalatok versenyképességi tényezőjének tekinthető (Jones \& Sasser, 1995).

A magas váltási költségeket tehát rendszerint árkedvezményekkel kombinálják a szolgáltatók az ügyfélszerzés reményében (Thomas et al., 2004; Chuang \& Tsaih, 2013), de a szakirodalom nem egységes atekintetben, hogy ez a stratégia hosszú távon eredményes-e (Lewis, 2006), illetve, hogy az ügyfélmegtartás szempontjából az árkedvezményeknek milyen hatása van. Összességében tehát az ügyfeleket a profitabilitásuk alapján kellene kiválasztani, az ügyfélszerzési költségek minimalizálása helyett (Thomas et al., 2004). Emellett az ügyfélmegtartásra gyakorolt hatását tekintve előnyösebb a kisebb mértékü, de hosszabb távú kedvezmény az egyszeri jelentős kedvezménynél (Lewis, 2005). 
A váltási költség a váltási korlátokhoz kötődik, amely vagy a meglévő szolgáltatóval való elégedetlenség miatti váltási nehézséget, vagy az ügyfél által érzett pénzügyi, szociális és pszichológiai terhet fejezi ki (Fornell, 1992). A váltási magatartást a szolgáltatás teljesítménye (például a fó szolgáltatásban vagy a szolgáltatás igénybevételében bekövetkezett hiba, a szolgáltató reakciója a hibára, etikai problémák) és a váltás költségei (például ár, kényelmetlenség, kényszerített váltás, verseny) határozzák meg (Keaveney, 1995).

A szolgáltatáskivezetés megvalósításának kedvezőtlen módját az ügyfél szolgáltatási hibaként (service failure) is értelmezheti. A telekommunikációs szektorban gyakori probléma, hogy a kényszerített migráció nagyban megnöveli a lemorzsolódást szolgáltatáskivezetés esetén (Somosi \& Kolos, 2014).

A szolgáltatáskivezetésnek sokkal inkább a figyelem középpontjába kellene kerülnie, figyelembe véve, hogy a folyamat megfelelő menedzselésén keresztül a szolgáltatásportfólió struktúrája javítható, a szolgáltatásinnováció felgyorsítható, az elzárt erőforrások felszabadíthatóak és legfőképpen, az ügyfelek elvesztése elkerülhetővé válik. Eredményeink a szolgáltatáskivezetés gyakorlati menedzselése által mind a vállalatok, mind pedig az akadémia számára hasznosak lehetnek.

\subsection{A TANULMÁNY KONTEXTUSA: A TELEKOMMUNIKÁCIÓS SZEKTOR}

Mivel a szolgáltatáskivezetéssel foglalkozó kutatások elsősorban a pénzügyi szektort vizsgálták Nyugat-Európában (Harness \& Mackay, 1997; Argouslidis, 2001, 2006; Harness \& Harness, 2007), célunk a szolgáltatáskivezetés empirikus eredményeinek bővítése a középkelet-európai telekommunikációs szektorban, mivel ez egy ideális stratégia lehet az innováció felgyorsítására. A téma relevanciája fokozatosan nő a telekommunikáció high-tech jellege miatt, amely túlzsúfolt szolgáltatásportfóliók kialakulásához vezet.

Tanulmányunk kontextusa a közép-kelet-európai telekommunikációs szektor, amely ideális a szolgáltatáskivezetést követő ügyfélreakciók tanulmányozására. Ennek két fő oka a szolgáltatások rövid életciklusa és a szolgáltatáskivezetés módját tekintve a meglévő szolgáltatások teljes kivezetésének gyakorlata (pl. a szolgáltatások részleges kivezetése helyett), amely utóbbi a kényszermigráció által jelentősen növeli az ügyfelek lemorzsolódásának veszélyét. Ez a kontextus azonban nem tartozik a szolgáltatáskivezetés népszerü területei közé, mint például a pénzügyi szektor, ezért a telekommunikációs szektor sajátosságait később mutatjuk be (2.4. fejezet).

A közép-kelet-európai régió Albániát, Bulgáriát, Horvátországot, a Cseh Köztársaságot, Magyarországot, Szlovákiát, Szlovéniát és a három balti államot foglalja magában: 
Észtországot, Lettországot és Litvániát (OECD, 2000). A lista egyes jelentésekben Ausztriával is kiegészül (Roland Berger, 2017).

De Jong and Vermeulen (2003) megkülönböztetik a termelés-intenzív szolgáltatásokat (pl. bank, biztosítás, telekommunikáció, szállítás és nagykereskedelem), amelyek az egyszerüsítésre és standardizálásra fókuszálnak; a beszállítók által dominált szolgáltatásokat (pl. személyes szolgáltatások, hotelek, éttermek, kiskereskedelem), amelyeket kevésbé tartanak innovatívnak; és a folyamatos vagy inkrementális innovációt a magas tudás intenzitás miatt (pl. IT, gépipar). A telekommunikációt high-tech tudás intenzív szolgáltatásként határozták meg (Eurostat, 2017).

\subsection{A DISSZERTÁCIÓ CÉLJA ÉS STRUKTÚRÁJA}

A disszertáció célja a szolgáltatáskivezetés tudományos eredményeinek bővítése, és a gyakorló szakemberek számára a folyamat jobb megtervezésének és kivitelezésének támogatása.

A disszertáció második fejezetében a szakirodalmi áttekintést mutatjuk be. Először a szolgáltatásmarketing alapjait tekintjük át, azokkal a főbb elméletekkel, amelyek hozzájérulnak a szolgáltatáskivezetés fogalmának megértéséhez (a szolgáltatások jellemzői és a szolgáltatás-domináns logika). Másodszor, a nemzetközi és magyar szolgáltatáskutatási prioritásokat jellemezzük, amely alapján a jelenlegi trendek viszonylatában pozícionáljuk kutatásunkat. A szolgáltatáskivezetés alapjait tehát a szolgáltatáskivezetés és jelenlegi kutatási prioritások kapcsolatán keresztül és a szolgáltatáskivezetéshez kapcsolódó elméletek segítségével mutatjuk be, mivel ezek szükségesek a szolgáltatáskivezetés tágabb aspektusainak mélyebb megértéséhez.

Harmadszor, kutatásunk fő témáját, a szolgáltatáskivezetés szakirodalmat mutatjuk be a szolgáltatáskivezetés három fö fázisa alapján: a szolgáltatáskivezetés előtti szakasz, a szolgáltatáskivezetés implementációja, és a szolgáltatáskivezetés utáni szakasz. Mivel kutatásunk középpontjában a szolgáltatáskivezetés ügyfelekre gyakorolt hatása áll, ezért a kivezetés utáni szakaszhoz kapcsolódó, a szolgáltatáskivezetés hatását magyarázó elméletek is bemutatásra kerülnek (társadalmi csere elmélet és igazságosság elmélet).

Negyedszer, a telekommunikációs szektor sajátosságait tekintjük át, amelyek meghatározzák a szolgáltatáskivezetés sikerességének értelmezését. Mivel a szolgáltatáskivezetést elsősorban a pénzügyi szektorban vizsgálták és a telekommunikáció kizárólag több szektort átfogó tanulmányokban jelent meg, ezért először a közép-keleteurópai régió telekommunikációs piaci szerkezetét szükséges megérteni a siker 
szolgáltatáskivezetés esetében való értelmezéséhez. Az ügyfélmegtartás a telekommunikációs szakirodalomban sikertényezőként került meghatározásra, amely azonban egyre nagyobb kihívást jelent a stagnáló piacokon, a vállalatok akvizíciós fókusza mellett. Ezáltal a szolgáltatások kivezetése a telekommunikációs szolgáltatók versenyképességét meghatározó tényezővé válik, annak magas lemorzsolódási kockázata miatt.

A szakirodalmi áttekintést a kutatási kérdések és módszertan követik (3. fejezet), ahol a koncepcionális modell alapján megfogalmazzuk kutatási kérdéseinket. A szolgáltatáskivezetésről általánosan a szakirodalomban korlátozott információ érhető el, különösképpen a kivezetés utáni sikerességről telekommunikációs környezetben, ezért egy kvalitatív módszertanra épülő esettanulmányt terveztünk (mélyinterjúk egy telekommunikációs szolgáltató döntéshozóival) a szolgáltatáskivezetés sikerességéhez kapcsolódó főbb kérdések megértésére. Ezek az eredmények a szakirodalmi áttekintéssel együtt képezik a hipotéziseink alapját, amelyeket a 3. fejezet végén mutatunk be a két fö módszertan szerint csoportosítva (kísérleti módszertan és adatbázis elemzés).

A 4. fejezet mutatja be a kutatást, amely három fő tanulmányból áll: két kísérleti módszertanra épülő tanulmány és egy adatbázis elemzés (Heckman- féle korrekciós eljárás). Mivel kutatásunk a szolgáltatáskivezetés ügyfélreakcióit vizsgálja, a módszertant ehhez igazítottuk: a válaszadók egy szcenárió alapú szolgáltatáskivezetés kísérletben vesznek részt, amely kiterjeszti a válaszadók lehetséges körét egy olyan kérdőívvel összehasonlítva, ahol csak olyanok vehetnének részt a megkérdezésben, akik már találkoztak hasonló helyzettel a múltban. Az 1. és 2. tanulmány tehát kísérleti módszertanra épül, a szolgáltatáskivezetés ügyfelekre gyakorolt hatását értelmező két fö elméleti csoport alapján (társadalmi csere elmélet és igazságosság elmélet), amelyeket a 2.3. fejezet végén mutatunk be. Másodsorban, mivel tisztában vagyunk a kísérleti módszertan korlátaival, a kutatási módszertant adatbázis elemzéssel is kiegészítettük (3. tanulmány), hogy egy telekommunikációs szolgáltató szolgáltatáskivezetési projektje során valós ügyfél magatartást modellezhessünk Heckmanféle korrekciós eljárással.

A disszertációt az eredmények összegzésével, szakirodalmi hozzájárulással és gyakorlati relevanciával zárjuk az 5 . fejezetben.

A disszertáció célját és szerkezetét a 2. ábra szemlélteti. A disszertáció három fő területe a szakirodalmi áttekintés, a kutatás fókusza és a gyakorlati relevancia. A szakirodalmi áttekintés úgy épül fel, hogy lehetővé tegye a szolgáltatáskivezetés megértését: a szolgáltatásmarketing alapjai és a jelenlegi kutatási trendek alakítják a szolgáltatáskivezetés 
fogalmát és relevanciáját. Mivel a tanulmány kontextusa a telekommunikáció, ez alapjaiban meghatározza a szolgáltatáskivezetés értelmezését. $\mathrm{Az}$ ábra többi része pedig a szolgáltatáskivezetés három fázisára épül: a szolgáltatáskivezetés előtti szakasz, amely befolyásolja a szolgáltatáskivezetés implementációját, amely végül a szolgáltatáskivezetés utáni szakaszt határozza meg, beleértve az ügyfelekre és a vállalatra gyakorolt hatást. Kutatásunk középpontjában a szolgáltatáskivezetés ügyfelekre gyakorolt hatása áll, amely akadémiai relevanciáján túl gyakorlati jelentőséggel is bír. A szolgáltatáskivezetés ügyfélreakciói meghatározzák a sikeres szolgáltatáskivezetési stratégiát. Habár a vállalatra gyakorolt közvetlen hatásokat nem tudjuk mérni, hiszen ez azt kívánná meg a vállalatoktól, hogy a szolgáltatáskivezetés utáni elemzéseket folytassanak a fenntartási és fejlesztési költségek csökkenésének és a bevétel megtakarítás nagyságának feltárására, a szolgáltatáskivezetés szakaszának mindkét aspektusának gyakorlati jelentősége nyilvánvaló. Hiszünk abban, hogy az ügyfél szempontú elemzésünk hozzájárulhat a szakirodalom ezen a területen lévő hiányosságainak betöltéséhez és emellett segíthet a vállalatoknak a megfelelő szolgáltatáskivezetési stratégia kialakításában.

\section{2. ábra: A disszertáció célja}

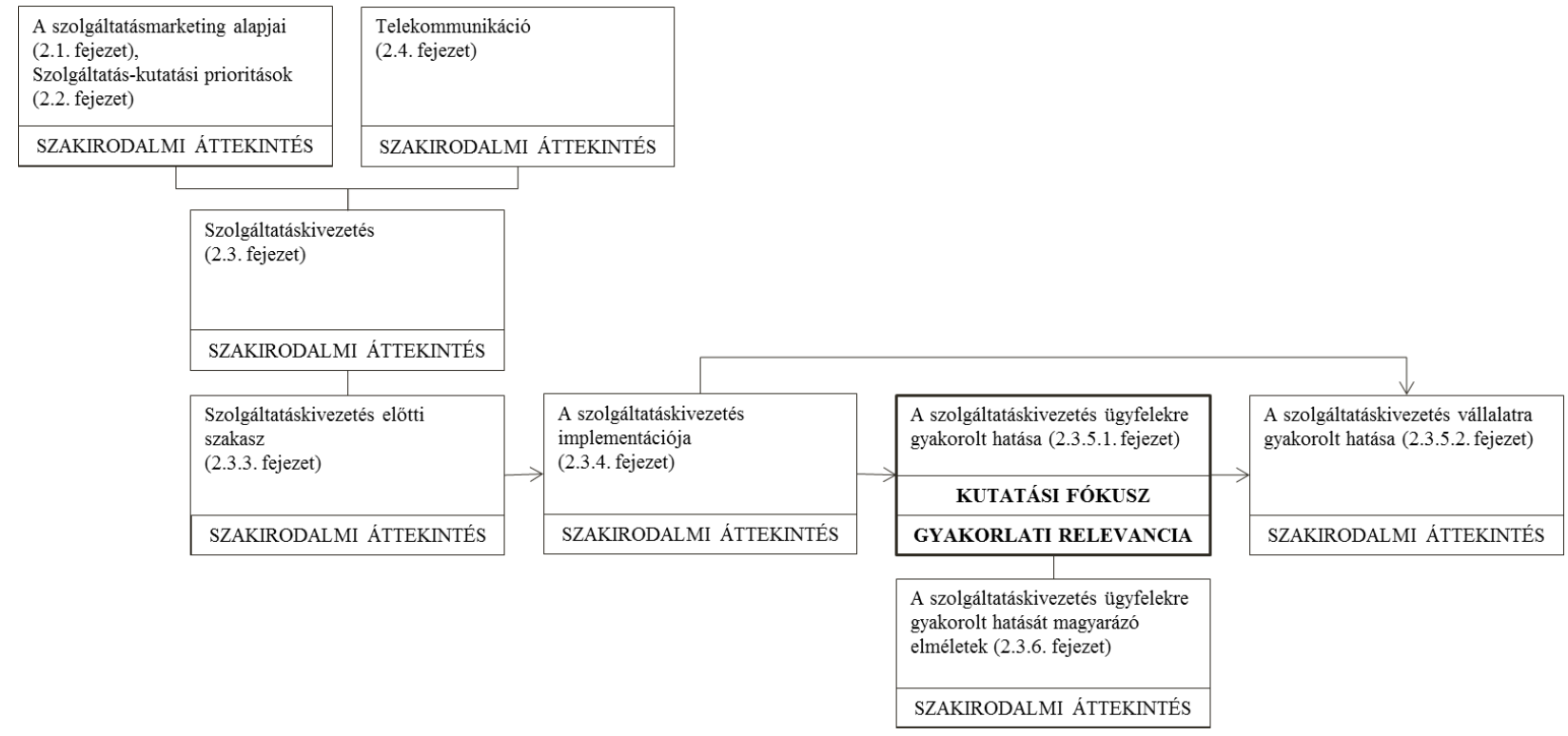

Forrás: saját szerkesztés 


\section{SZAKIRODALMI ÁTTEKINTÉS}

„Az Univerzumról megszerzett összes tudás nem volt több, mint kavicsokkal és kagylókkal való játék az igazság nagy óceánjának partján.”

(Isaac Newton)

A szolgáltatáskivezetés meglepően alulkutatott terület a szakirodalomban, habár gyakorlati relevanciája folyamatosan nő. A szolgáltatáskivezetés elhanyagoltságát részben az is magyarázhatja, hogy a téma meglehetősen összetett, számos, látszólag egymástól független területhez kötődik. A legnyilvánvalóbb kapcsolat a termékek és szolgáltatások különválasztásából adódik. A szakirodalomban a termékek és szolgáltatások eltérő sajátosságainak vizsgálata a szolgáltatásmarketing kezdeteire nyúlik vissza. A szolgáltatások definiálását követően a szakirodalom a szolgáltatások dominanciáját hangsúlyozta, hiszen a szolgáltatások a gazdaságban is túlsúlyba kerültek világszerte. A termékek és szolgáltatások közti vitához hasonlóan a szolgáltatáskivezetés és termékkivezetés között is találunk lényegi eltéréseket és hasonlóságokat. Emellett a jelenlegi kutatási prioritásokba illeszkedik a szolgáltatáskivezetés, amely a vállalat erőforrásainak felszabadítása által lehetővé teszi az innováció felgyorsítását.

A más elméletekkel való másik kapcsolat a szolgáltatáskivezetés különböző perspektívákból való vizsgálatából adódik. A vállalati perspektíva rendszerint a döntési folyamatra fókuszál, míg az ügyfél szempontú vizsgálat a szolgáltatáskivezetés számos területéről gyakran hiányzik annak ellenére, hogy a szolgáltatáskivezetési döntés ügyfelekre gyakorolt hatásának értelmezéséhez elengedhetetlen ennek ismerete. Ez a terület számos elmélethez kapcsolható: elsőként az ügyfélreakciókhoz (ügyfélmegtartás, elégedettség, elkötelezettség, lojalitás és szájreklám), másodsorban pedig olyan elméletekhez, amely az ügyfelekre gyakorolt hatást értelmezik (társadalmi csere elmélet és igazságosság elmélet).

Vagyis a szakirodalmi áttekintés során a szolgáltatásmarketing szakirodalmat tágabban értelmezve tekintjük át, amelyek meghatározzák a szolgáltatáskivezetés kialakulását és relevanciáját. Ez segít a szolgáltatáskivezetés fő kérdéseinek a meghatározásában, legfőképpen a szolgáltatáskivezetés eredményét tekintve.

Ahhoz, hogy az elméletek összefüggésrendszerét értelmezni tudjuk, a szakirodalmi áttekintésben a szolgáltatásmarketing evolúcióját követjük: kezdve a szolgáltatások alapfogalmaival, és a szolgáltatás-domináns logikával. Majd a szolgáltatáskivezetés 
összevetése a jelenlegi kutatási prioritásokkal segít a szolgáltatáskivezetés értelmezésében, a szakirodalomban alulkutatott területek feltárásában, és a folyamat előzményeinek, folyamatának és eredményeinek azonosításában. Mivel az ügyfelekre gyakorolt hatás képezi tanulmányunk központi részét, az ügyfél perspektívához kötődő elméleteket is bemutatjuk (társadalmi csere elmélet és igazságosság elmélet). Végül, mivel a telekommunikáció a szolgáltatáskivezetés ügyfél szempontú elemzésének nem gyakran alkalmazott kontextusa, ezért a közép-kelet-európai telekommunikációs piac kialakulását, majd a releváns telekommunikációs szakirodalmat is áttekintjük, hogy megérthessük annak kapcsolatát a szolgáltatáskivezetéssel.

\subsection{A SZOLGALTATÁSMARKETING ALAPJAI}

A következő fejezetben áttekintjük a szolgáltatás definíciójának kialakulását, valamint a szolgáltatásmarketing fejlődését, végül a jelenlegi kutatási prioritásokat. A szolgáltatásmarketing szakirodalmon belül azokat a területeket emeljük ki, amelyek szükségesek a szolgáltatáskivezetés különböző aspektusainak megértéséhez.

A GDP szolgáltatás által termelt aránya világszerte 63\% (2016-os becslés) (Central Intelligence Agency, 2017), de az Európai Unión belül ez az arány még ennél is magasabb (70,5\%). Magyarország esetében ez az érték a kettő között van, 64,7\%. Vagyis napjainkban a legtöbb országban a gazdaságot a szolgáltató szektor túlsúlya jellemzi, a mezőgazdaság és ipar (gyártás és bányászat) háttérbe szorításával, amely egyúttal azt is jelenti, hogy a marketing szakirodalomnak is követnie kellene ezt a változást, a hagyományos, termelés központú megközelítéstől való eltávolodással, a szolgáltatás kultúra jobb megértése érdekében.

\subsubsection{A SZOLGÁLTATÁSOK JELLEMZÖI}

A szolgáltatási szektor dominanciája megalapozta a szolgáltatások definícióját, amely elsősorban a termékekhez való viszonyát emeli ki. Számos szolgáltatás definíció született, amelyek először még nem a termékek és szolgáltatások közti különbségeket határozták meg, hanem csak azt emelték ki, hogy „, [a szolgáltatás] a termék definícióval együtt, a „,közgazdasági jószág” fogalmát merítik ki” (Judd, 1964, 58-59. o.). Minden további, szolgáltatás definiálására irányuló kísérlet azokat a szolgáltatás tulajdonságokat emelte ki, amelyek a termékekre nem jellemzőek, például „, a szolgáltatásmarketing a tevékenységek és folyamatok marketingjét jelenti, nem tárgyakét" (Solomon, 1985, 106. o.), vagy a szolgáltatást úgy definiálták, hogy „,folyamat vagy teljesitmény, nem tárgy” (Lovelock, 1991, 
13. o.). A szolgáltatások megfelelő definíciójának kialakításával kapcsolatban meg kell jegyeznünk, hogy egy külön dimenzió foglalkozik a szolgáltatások egy sajátos típusával, a professzionális szolgáltatásokkal (Gummesson, 1978).

Néhányan a termékek és szolgáltatások közötti kettősséget hangsúlyozzák, és ezáltal a kérdés már nem a termékek és szolgáltatások közti eltérésekről, hanem azok szolgáltatásokon belüli arányáról szól: „, A szolgáltatások olyan gazdasági tevékenységek, amelyeket az egyik fél nyújt a másik számára. Gyakran időhöz kötötten, ezek a teljesitmények elvárt eredményeket hoznak létre a fogadó fél, tárgyak vagy más eszközök számára” (Wirtz \& Lovelock, 2016, 21. o.). „A szolgáltatások ügyfelei a pénzért, idöért és a befektetett energiáért értéket várnak el, hogy hozzáférhessenek munkához, képességekhez, szakértelemhez, javakhoz, létesitményekhez, hálózatokhoz és rendszerekhez. Habár általában nem szerzik meg a folyamatban részt vevö fizikai elemek tulajdonjogát” (Edvardson et al., 2005, 112. o.).

Meglepő módon a termékek és szolgáltatások között fennálló vita még nem zárult le, de bizonyos tényezők a legtöbb definícióban fellelhetőek: „tevékenységek” vagy „folyamatok”, utalva a szolgáltatásnyújtás közvetlen vagy közvetett módjára (Vargo \& Lusch, 2004): „,a szakkompetenciák (képességek és tudás) alkalmazása cselekvéseken, folyamatokon és teljesitményeken keresztül egy másik entitás vagy a saját entitás (önkiszolgáló szolgáltatás, self-service) számára a megfogható javakon keresztül, mivel a javak a szolgáltatás nyújtásának ellátási mechanizmusát képezik” (Vargo \& Lusch, 2004, 326. o.).

Ez azt jelenti, hogy a szolgáltatások a termékeket is magukban foglalhatják vagy kapcsolódhatnak hozzájuk termékek, vagyis ez sokkal inkább egy befogadó típusú definíció. Mi ezt a megközelítést követjük, hiszen esetünkben a szolgáltatáskivezetés is rendszerint a fizikai termékek és szolgáltatások valamely kombinációjának tekinthető.

A termékek és szolgáltatások közti különbségek négy fontos szolgáltatás tulajdonságot emelnek ki, ezek a következőek: változékonyság, megfoghatatlanság, tárolhatatlanság és elválaszthatatlanság. A szolgáltatásmarketing szakirodalom ezt nevezi HIPI-elvnek, a szavak angol kezdőbetűinek kialakított rövidítéséből (heterogeneity, intangibility, perishability, inseparability), amely föként a '80-as években volt a kutatások központi témája (Zeithaml et al., 1985). Másfelől a téma a kockázat csökkentéshez is kapcsolódik, hiszen a fogyasztók HIPI tulajdonságokkal való megküzdése érdekében kialakított stratégiák összességében csökkentik a fogyasztó által észlelt kockázatot: egy hosszabb döntési folyamatban hajlandóak részt venni, ahol a személyes információ szerepe kulcsfontosságú, amely általánosságban 
sokkal hatékonyabb szolgáltatások, mint termékek esetén, különösképpen belső források esetén külső forrásokkal összevetve (Murray, 1991).

A termékek és szolgáltatások közti vitát követően, a szolgáltatásmarketingben különböző korszakok követték egymást, amelyek összességében hatással voltak a mai szolgáltatásmarketing szakirodalom kialakulására. Fisk és szerzőtársai (1993) a szolgáltatásmarketing három fő korszakát határozták meg:

1. Megjelenés, 1980 előttig (crawling out): ez a korszak egészen a szolgáltatásmarketing megszületéséig, 1953-ig nyúlik vissza, és legfőképpen az előbb bemutatott termékszolgáltatás vitával jellemezhető. A manapság híres szolgáltatásmarketing kutatók ekkoriban kezdték pályafutásukat (például John Bateson, Leonard Berry, Stephen Brown, John Czepiel, Pierre Eiglier, William George, Christian Grönroos, Eugene Johnson, Eric Langeard, Christopher Lovelock, és Lynn Shostack).

2. Felgyorsulás, 1980-1985 (scurrying about): ezekben az években egy nagyobb közösség csatlakozott a szolgáltatásmarketing területéhez, és így a szakirodalom jelentősen megnőtt. Fisk és szerzőtársai (1993) két jelentős fejlődésre hívják fel a figyelmet, amelyek ezt a folyamatot elindították: a szolgáltató ipar deregularizációja és az Amerikai Marketing Szövetség konferenciáin kialakult diskurzus. Emellett két jelentős szaklapot is alapítottak: a Service Industries Journal-t 1980-ban és a Journal of Professional Services Marketing-et 1985- ben. Ebben az időszakban alakultak ki a szolgáltatásmarketing alapjai: a szolgáltatások besorolási rendszerei (Lovelock, 1983), a szolgáltatások egyedi tulajdonságait összefoglaló koncepcionális keret (Zeithaml et al., 1985), a szolgáltatási folyamat kritikus elemei és a szolgáltató és ügyfél közötti interakció (Solomon et al., 1985).

3. Továbbhaladás, 1986-tól mostanáig (walking erect): a korszakban megjelenő kutatási témák többek között a szolgáltatásminőség (Lehtinen \& Lehtinen, 1982; Grönroos, 1983; Parasuraman et al., 1991), a szolgáltatási folyamat/élmény (Solomon et al., 1985; Surprenant \& Solomon, 1987), szolgáltatás design (Shostack, 1984; Shostack, 1987; Kingman-Brundage, 1989), ügyfélmegtartás és kapcsolati marketing (Crosby \& Stephens, 1987; Hart, 1988; Crosby et al., 1990; Hart et al., 1990; Berry \& Parasuraman, 1991), belső marketing (Grönroos, 1981; George, 1990), stb. A terület interdiszciplináris és nemzetközi jellege volt hangsúlyos (Bitner, 1992; Larsson \& Bowen, 1989). A cikkek is sokkal empirikusabbak lettek, a koncepcionális viták leírása 
helyett. Két szaklapot alapítottak: a Journal of Services Marketing-et 1987-ben, és az International Journal of Service Industry Management-et 1990- ben.

Habár ezek az eredmények nem jellemzik a jelenlegi kutatási trendeket, amelyeket a 2.2. fejezetben tekintünk át, az világos, hogy egy kifinomult szolgáltatáskivezetés szakirodalom egyszerüen nem volt még időszerü a 2000'-es évek előtt, hiszen a legtöbb szolgáltatásmarketing definíció még csak ezelött körvonalazódott. A szolgáltatáskivezetéshez egy meglehetősen érett szolgáltatásmarketing szakirodalomra van szükség, ahol a szolgáltatásfejlesztések kezelése portfólió szinten történik, és ezáltal a szolgáltatáskivezetés ezen döntések egy részének tekinthetö.

\subsubsection{SZOLGÁLTATÁS-DOMINÁNS LOGIKA (SDL)}

Ahogyan láthattuk, rengeteg változás történt a szolgáltatásmarketing szakirodalomban. Kezdetben a szolgáltatások termelés-központú szemlélettől való elválasztása volt a cél, amely bizonyos értelemben még ma sem zárult le. A következő jelentős paradigmaváltás, amely a mai szolgáltatásmarketinget meghatározza, a szolgáltatás-domináns logika (service dominant logic, SDL) megjelenése volt (Vargo \& Lusch, 2004).

Jóval Vargo és Lusch híres cikke előtt azonban számos kutató hangsúlyozta a termékek és szolgáltatások hagyományos nézetének elavultságát (Webster, 1992; Rust, 1998; Achrol \& Kotler, 1999; Day \& Montgomery, 1999). Például Gummesson (1995) azt emelte ki, hogy az ügyfelek ajánlatokat vásárolnak, és tulajdonképpen a termékek vagy szolgáltatások az értéket állítják elő. A szolgáltatás-központú szemlélet ilyen értelemben sokkal inkább a vevő szemszögéről szól, mint a termékek és szolgáltatások közti különbségekről.

A szolgáltatás-domináns logika szerint a termékeket és a szolgáltatásokat értékteremtés perspektívából kell vizsgálni, ahol az érték a vevő és az őt körülvevő piaci szereplők közti együttmüködés eredménye. Vagyis ez alapján nem a vállalati értékteremtés alakítja ki az üzleti stratégiát, hanem az együtt- teremtés (co-creation), és az értéket az ügyfél állítja elő a vállalat támogatásával. Ezáltal a co-creation-t ösztönző erőforrások képezik a versenyelöny forrását.

Tehát a szolgáltatás-domináns logika fő gondolata az, hogy az ügyfél a szolgáltatások előállításában részt vesz, tehát több egy befogadónál. Ez megkérdőjelezi a termékfejlesztés korábbi logikáját, hiszen már nincsen hagyományos értelemben vett végső fogyasztó a folyamatban, hanem az ügyfél a vállalat tevékenységének résztvevője.

A szolgáltatás-domináns logikához a következő fogalmak kötődnek (Vargo \& Lusch, 2004): immateriális javak, kompetenciák, dinamikák, cserefolyamatok és kapcsolatok, és 
müködtető (operant) erőforrások. A müködtetett (operand) és müködtető (operant) erőforrások közti különbséget Constantin és Lusch (1994) definiálta: a müködtetett (operand) erőforrások azok, amelyeken egy mủveletet vagy tevékenységet hajtanak végre egy hatás létrehozása érdekében; amíg a müködtető (operant) erőforrásokat használják a működtetett erőforrásokon való műveletekhez. A képességek és tudás legfontosabb erőforrásként való kiemelése világított rá a müködtető (operant) erőforrásokra, amelyet Zimmermann (1951) és Penrose (1959) ismert fel. Ahogyan Penrose fogalmaz: „soha nem az erőforrások önmagukban a termelési folyamat inputjai, hanem kizárólag a szolgáltatások, amelyeket az eröforrások hoznak létre” (Penrose, 1959, 24-25. o.).

Vargo és Lusch a szolgáltatás-középpontú nézetét a következőképpen definiálják (Vargo \& Lusch, 2004, 5. о.):

1. Az alapvető kompetenciák (core competences) azonosítása és kialakítása, elsősorban az alapvető tudás és képességek, amelyek a versenyelőny forrásai;

2. Más entitások azonosítása (pl. potenciális ügyfelek), akik profitálhatnak ezekből a kompetenciákból;

3. Az ügyfelek személyre szabott, versenytársakkal szemben is vonzó értékajánlatok előállítási folyamatba való bevonása, amelynek eredménye az egyedi igényeknek való megfelelés;

4. A pénzügyi teljesítmény elemzésével visszajelzés gyüjtése, amely hozzájárul a vállalat ügyfelek számára nyújtott ajánlatainak fejlesztéséhez, és ezáltal a vállalati teljesítmény növeléséhez.

A későbbiekben Vargo és Lusch (2008) a szolgáltatás-domináns logika koncepcióját a következőképpen finomította:

- A tudás és képességek képezik a közvetett csere alapját;

- A termékek a szolgáltatások elosztási mechanizmusának tekinthetőek;

- A tudás a verseny alapvető forrása;

- Minden gazdaság szolgáltatásgazdaság;

- A vevő részt vesz az előállítási folyamatban;

- A vállalat nem tud értéket teremteni, csak érték ajánlatokat;

- A szolgáltatás-központú nézet mindig vevőorientált és kapcsolati;

- A szervezetek elsődleges célja a kompetenciák szolgáltatásokká való integrálása és átalakítása. 
Vagyis a szolgáltatás-domináns logika kapcsolódik az értékteremtéshez, hiszen lehetőséget teremt olyan szolgáltatások előállítására, amelyek megfelelnek a fogyasztói standardoknak, ez azt jelenti, hogy ideális esetben nem létezhet többé céltalan szolgáltatásfejlesztés. Azonban a gyakorlatban nem mindig ez történik: a vállalat még mindig domináns az értékteremtésben (Strandvik et al., 2012). Vargo és szerzőtársai (2016) ma már szolgáltatás ökoszisztémáról beszélnek, amely a szolgáltatás-domináns logika kiterjesztésének tekinthető. A digitalizáció ehhez pedig személyre szabott, magas minőségü szolgáltatásokat biztosít szorosabb ügyfélkapcsolatokkal.

A szolgáltatás-domináns logikával összefüggésben két megközelítés jelent meg az utóbbi években: a szolgálatosodás (servitization), amely a termék-szolgáltatás rendszerek elemzésével és kialakulásával foglalkozik (Pawar et al., 2009; Demeter, 2010; Demeter \& Szász, 2012) és a szolgáltatás -infúzió (service infusion), amely a szolgáltatások növekedésének egyetlen lehetséges útját, az interszektoriális és nemzetközi stratégia kialakítását hangsúlyozza (Zeithaml et al., 2014). Mindkét fogalom a szolgáltatások bevezetéséhez kötődő versenyt emeli ki, vagyis a versenyelőny gyakran kiegészítő szolgáltatásokból ered.

\subsection{SZOLGALTATÁS-KUTATÁSI PRIORITÁSOK}

A szolgáltatásmarketing szakirodalom áttekintését követően megállapíthatjuk, hogy a szolgáltató szektor egyértelmüen meghatározza a mai gazdaságot, és a szakirodalom is követte ezt az irányt főként az új szolgáltatásfejlesztés, szolgáltatáskínálat menedzsment, és co-creation területén. A szolgáltatáskivezetés ügyfélreakcióinak pontosabb megértésén keresztül a téma befolyásolhatja az aktuális jövőbeli kutatási irányokat. Témánk pozícionálása érdekében áttekintjük a jelenlegi kutatási prioritásokat, először világviszonylatban, majd Magyarországon.

\subsubsection{A SZOLGÁLTATÁSKUTATÁS ÁTTEKINTÉSE}

Ostrom és szerzőtársai (2015) 12 szolgáltatáskutatási prioritást határoztak meg 5 fö területen (3. ábra). Ezek a következők: stratégiai prioritások, design, tervezési/teljesítési prioritások, értékteremtési prioritások, eredmény prioritások, és átfogó (cross-cutting) prioritások, amely utóbbiak bármely négy prioritáshoz kapcsolódhatnak. A fó csoportok kialakítása a szolgáltatások folyamat jellegét tükrözi, hiszen a szolgáltatásfejlesztés definíciói általában ezeket az aspektusokat emelik ki. Vagyis mindenekelőtt a stratégiai szint priorizálja a szolgáltatásfejlesztést, amely megjelenik a szolgáltatás design-ban is végighaladva a 
szervezeten, értéket teremtve úgy, hogy a jóléthez is hozzájárul a folyamat eredményeként. A technológia segíti a folyamatot, hiszen a legtöbb szolgáltatás innováció valamilyen módon technológia által vezérelt, ez alól kivételt képez például az új szolgáltatási koncepció, az ügyfél érintkezési felület vagy a teljesítési rendszer (De Jong \& Vermeulen, 2003).

A stratégiai prioritások a szolgáltatásinnováció ösztönzését, a szolgálatosodás megkönnyítését, szolgáltatás- infúziót és ahhoz kapcsolódó megoldásokat, a szervezet megértését és a szolgáltatás sikerességéhez kapcsolódó alkalmazotti kérdéseket foglalják magukban. Elöször is, a komplex szolgáltatási rendszereken és értékhálózatokon belüli szolgáltatás innováció meglehetősen nagy kihívásokkal jár a vállalatok számára, az innovációs folyamat során ügyfelekkel és partnerekkel kialakuló kölcsönös kapcsolatok és az innovációs formák különböző típusai miatt (szolgáltatás-termék, szolgáltatás-folyamat és üzleti modell innováció). Másodszor, a szolgálatosodás (Kastalli \& Van Looy, 2013) a szükséges transzformációs folyamatok és támogató technológiák által megvalósuló új üzleti modell fejlesztésre vonatkozik, míg a szolgáltatás- infúzió azt fejezi ki, hogy az ügyfélorientált szolgáltatások a termékközpontú üzleti modell részévé válnak (Zeithaml et al., 2014). Harmadszor, az alkalmazotti kérdések a „szolgáltatások elgépiesedésének” (dehumanization of services) drámai folyamatát emelik ki, amelyet a vállalatoknak kezelniük kell.

A design/teljesítési prioritások a következőek: a szolgáltatási hálózatok és rendszerek kialakítása, a szolgáltatás design fejlesztése és a big data használata a szolgáltatások továbbfejlesztésére. Az információs rendszerek által elérhető hálózatokban zajlik a szolgáltatások tervezése, előállítása és fogyasztása. Továbbá a szolgáltatástervezés/design az új szolgáltatások létrehozásának emberközpontú, kreatív és iteratív megközelítése (Blomkvist et al., 2010), amely a co-creation-nel való kombinációja által növelheti a szolgáltatás élményt. Harmadszor, a big data hasznosítani tudja az értékesítési adatok, ügyfél üzenetek, közösségi oldalak posztjai, vagy helyinformáció, stb. által generált hatalmas adatmennyiséget, azonban a vállalatoknak ügyelniük kell az ügyfél adatbiztonságra és személyre szabott szolgáltatásokra vonatkozó igényeire.

Az értékteremtési prioritások közé tartozik az értékteremtés megértése és a szolgáltatásélmény fokozása. Először is, az értékteremtés megértése arra vonatkozik, hogy az érték több szereplő együttmüködése által jön létre és végül így jut el az ügyfélhez. Ezáltal a szerepek és erőforrások integrációjával jár és az értékteremtés koordinálásával összefüggésben rengeteg kihívást hordoz magában. Másodszor, a szolgáltatási élmény számos 
módon fokozható, mint például a co-creation, azzal a kiegészítéssel, hogy az összetett, diverz ajánlatokat és csatornákat a folyamat során kezelni kell.

Az eredmény (outcome) prioritások része a jólét transzformatív szolgáltatás által történő fejlesztése, valamint a szolgáltatás teljesítményének és hatásának mérése, valamint optimalizálása. A szolgáltatások nemcsak a vállalati értékteremtésről szólnak, hanem a hangsúly sokkal inkább a társadalmon van. A transzformatív szolgáltatáskutatás magában foglalja a szolgáltatás jóléti vonatkozásainak vizsgálatát, mint a fenntarthatóság, vagy a technológia felhasználása a jólét emelésére, veszélyeztetett fogyasztók számára nyújtott szolgáltatások, stb. Másodszor, a szolgáltatás teljesítmény mérése is egy eredmény prioritás, amely kifejezi a jobb mérési eszközök iránti igényt, amelyek képesek az érték becslésére, valamint a szolgáltatás megtérülésének kiszámítására, szolgáltatási standardok és mérőeszközök kifejlesztésére, stb.

Az átfogó (cross-cutting) prioritások a szolgáltatás globális kontextusban való megértésére és a technológia szolgáltatásfejlesztésre való felhasználására vonatkozik. A két átfogó prioritás összefügg a fent bemutatott négy prioritással, ezáltal hangsúlyozva a globális kutatások jelentőségét és a technológia szerepét a fogyasztók és vállalatok számára egyaránt értéket biztosító szolgáltatok előállításában.

\section{3. ábra: Szolgáltatáskutatási prioritások}

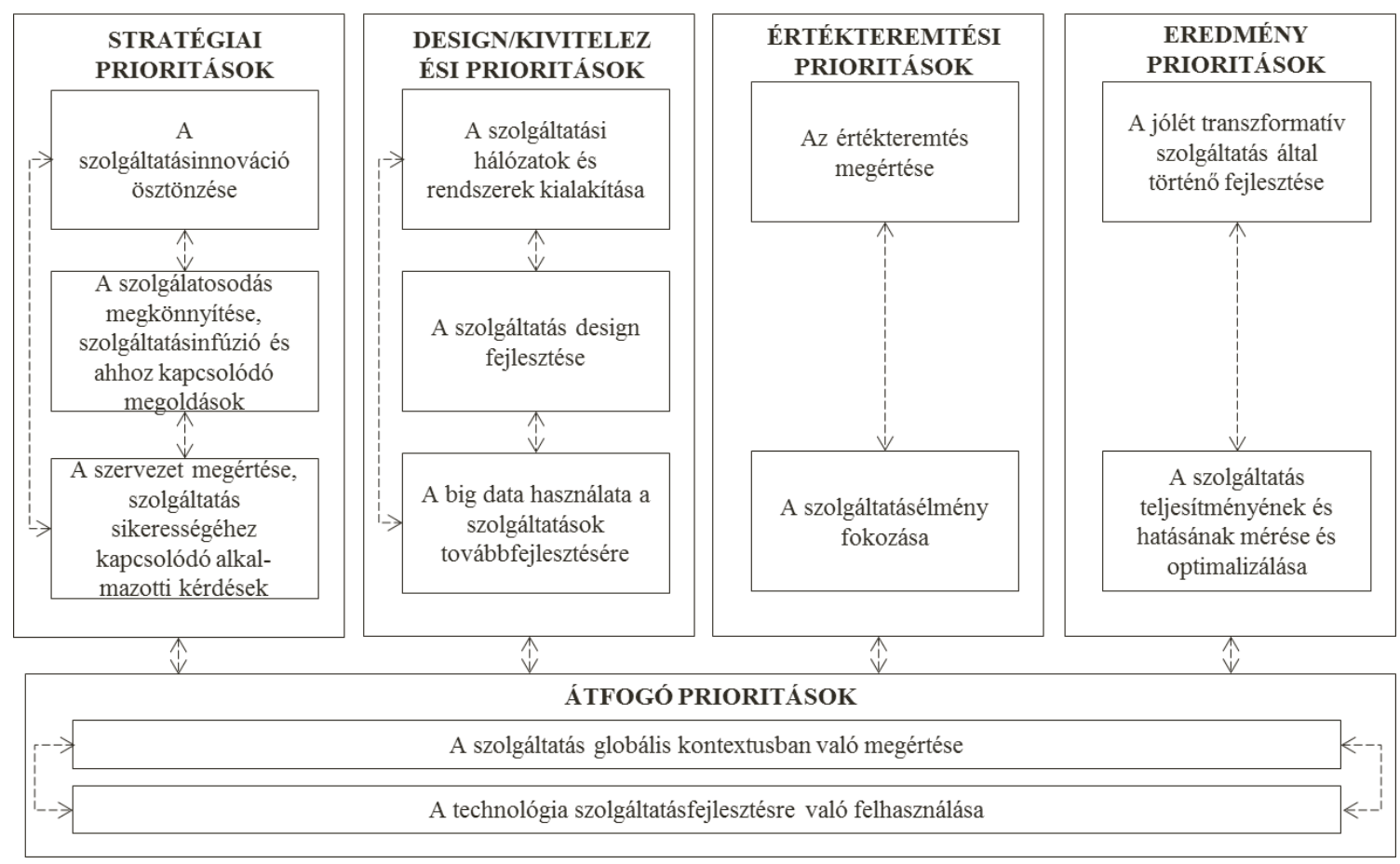

Forrás: Ostrom és szerzőtársai (2015: 129. o.) 


\subsubsection{A SZOLGÁLTATÁSKIVEZETÉS KAPCSOLATA A FÖBB KUTATÁSI PRIORITÁSOKKAL}

A szolgáltatáskivezetés a következő négy szolgáltatáskutatási prioritás esetében lehet releváns (1. táblázat): a szolgáltatásinnováció ösztönzése, szolgáltatás design fejlesztése, a szolgáltatásélmény fokozása, és a technológia szolgáltatásfejlesztésre való felhasználása. A szolgáltatáskivezetés egy nagyon összetett folyamat: a vállalatok folyamatos szolgáltatásinnovációs kényszerében a szolgáltatáskivezetés segítséget nyújthat a szolgáltatásportfólió szerkezetének optimalizálásában, de emellett a szolgáltatásélmény fokozására is szükség van, az ügyfelek megtartása érdekében. A folyamat végeredményeképpen pedig javíthatjuk az egyéni jólétet, és tágabb értelemben véve elérhetjük a közösségeket is, amely napjainkban a legtöbb esetben nem lenne lehetséges technológiai fejlesztések nélkül.

A szolgáltatáskivezetésnek valószínüleg a legközvetlenebb hatása a szolgáltatásinnovációra van, hiszen a szolgáltatások kivezetése által az új szolgáltatások fejlesztési folyamata felgyorsítható, a szolgáltatásfolyamat és az üzleti modell innováció esetében egyaránt. A szolgáltatáskivezetés megfelelő menedzsmentjével a vállalatok felfrissíthetik szolgáltatásportfólióikat, egy felgyorsított innovációs folyamat által.

Másodszor, a szolgáltatásportfólió racionalizálása felszabadítja a vállalati erőforrásokat, ezáltal hozzájárulva a fenntartási és fejlesztési költségek csökkentéséhez, és ezáltal a szolgáltatások tervezése is javul. Emellett a szolgáltatás design és a szolgáltatásélmény is nagyban fokozható, ha a szolgáltatási ajánlatokat a vállalatok az ügyfelekkel együtt dolgozzák ki (co-creation).

Harmadszor, a szolgáltatáskivezetés számos ponton kapcsolódik a szolgáltatásélményhez, amelyet a szolgáltatáskivezetés szerkezete és folyamata erősen befolyásol: a folyamattal és az új elérhető ajánlatokkal kapcsolatos hiányos információk alacsony ügyfélélményhez vezethetnek. Ez elkerülhető a projekt indulása előtti részletes ismertetéssel, és folyamatos kapcsolattartással, amennyiben az ügyfél igényli azt.

Végül a technológia a szolgáltatáskivezetési folyamat során egy előmozdító eszköznek tekinthető, amely a szolgáltatáskivezetési folyamat egyszerűsítésére használható (például az ügyfél számára küldött értesítések, az ügyfél igényeire szabott általános kommunikációs eszközök, egyedi ajánlatok kialakítása, stb.). A közösségi média kiemelt jelentőségü lehet a szolgáltatáskivezetés fejlesztésében, hiszen folyamatos visszajelzési lehetőséget biztosít az ügyfél számára. 
1. táblázat: A szolgáltatáskivezetés kapcsolata a szolgáltatáskutatási prioritásokkal

\begin{tabular}{|c|c|}
\hline STRATÉGIAI PRIORITÁS & A SZOLGÁLTATÁSKIVEZETÉSSEL VALÓ KAPCSOLATA \\
\hline A szolgáltatásinnováció ösztönzése & $\begin{array}{l}\text { - A szolgáltatáskivezetéssel az új szolgáltatások fejlesztése felgyorsítható, a } \\
\text { szolgáltatásfolyamat és üzleti modell innováció esetében egyaránt; } \\
\text { - A már elavult szolgáltatások kivonása lehetővé teszi személyre szabott } \\
\text { szolgáltatások fejlesztését. }\end{array}$ \\
\hline $\begin{array}{l}\text { DESIGN/KIVITELEZÉSI } \\
\text { PRIORITÁS }\end{array}$ & A SZOLGÁLTATÁSKIVEZETÉSSEL VALÓ KAPCSOLATA \\
\hline A szolgáltatás design fokozása & $\begin{array}{l}\text { - Az egyszerüsített szolgáltatásportfólió csökkenti a fejlesztési és fenntartási } \\
\text { költségeket; } \\
\text { - A szolgáltatásportfólió struktúrája optimalizálható; } \\
\text { - Az ügyfelekkel való közös értékteremtés -és tervezés (co-creation és co- } \\
\text { design) mind a szolgáltatástervezést, mind pedig a szolgáltatásélményt } \\
\text { fokozza a szolgáltatáskivezetés során. }\end{array}$ \\
\hline $\begin{array}{l}\text { ÉRTÉKTEREMTÉSI } \\
\text { PRIORITÁS }\end{array}$ & A SZOLGÁLTATÁSKIVEZETÉSSEL VALÓ KAPCSOLATA \\
\hline A szolgáltatásélmény növelése & $\begin{array}{l}\text { - A szolgáltatáskivezetési folyamat megfelelő tervezésével javítható a } \\
\text { szolgáltatáskivezetés során tapasztalt szolgáltatásélmény; } \\
\text { - Az ügyféllel való közvetlen kommunikáció során a kivezetésről és az } \\
\text { elérhető új ajánlatokról nyújtott részletes információ még a kivezetés } \\
\text { megkezdése előtt növelheti a szolgáltatásélményt szolgáltatáskivezetés } \\
\text { során. }\end{array}$ \\
\hline ÁTFOGÓ PRIORITÁS & A SZOLGÁLTATÁSKIVEZETÉSSEL VALÓ KAPCSOLATA \\
\hline $\begin{array}{l}\text { A technológia } \\
\text { szolgáltatásfejlesztésre való } \\
\text { felhasználása }\end{array}$ & $\begin{array}{l}\text { - A technológia szolgáltatás innovációt és új üzleti modelleket támogató } \\
\text { eszközként való használata, amely egyszerüsíti a szolgáltatáskivezetési } \\
\text { folyamatot; } \\
\text { - A közösségi média közvetlen kommunikációt tesz lehetővé az ügyfél és a } \\
\text { szolgáltató között, ezáltal csökkentve az ügyfelek elvesztésének kockázatát } \\
\text { szolgáltatáskivezetés során; } \\
\text { - A szolgáltatáskivezetés segít a szolgáltatás architektúra optimalizálásában, } \\
\text { amely megkönnyíti a szervezetek közötti és szervezeten belüli integrációt. }\end{array}$ \\
\hline
\end{tabular}

Forrás: Ostrom és szerzőtársai (2015) alapján saját szerkesztés

Ezen kutatási prioritásokat két átfogó koncepció határozza meg, amelyek a legerősebben befolyásolják a szolgáltatáskivezetést: a szolgáltatásinnováció és a co-creation. A szolgáltatásinnováció egy folyamatként értelmezhető, egészen a stratégiai döntéshozástól, amely a társadalom jólétét célozza meg, míg a co-creation az ügyfél folyamatban betöltött aktív szerepét hangsúlyozza, a befogadó szerep helyett. Ha az ügyfél részt vesz az előbb felsorolt szolgáltatáskutatási prioritások összes lépésében, akkor a vállalati stratégia és szolgáltatás design az ügyfél igényeire szabható, amely összességében magasabb előállított értékhez vezet, és ezáltal a jólét növelhető. Ebben az értelemben tehát a szolgáltatásinnováció és a co-creation sok szempontból összefüggnek.

Az első koncepció, amely szorosan kapcsolódik a szolgáltatáskutatási prioritásokhoz, az a szolgáltatásinnováció. A fenntartható szolgáltatásinnováció egyik mozgatórugója lehet, ha a szolgáltatáskivezetést a vállalat megfelelően tervezi és hajtja végre. Ezáltal ösztönzi a szolgáltatásinnovációt, hiszen a szolgáltatások aktualizálása az új szolgáltatások fejlesztésének része (Gustafsson \& Johnson, 2003). Tehát ezek alapján úgy gondoljuk, hogy a 
jelenlegi szolgáltatáskutatási prioritások és a szolgáltatáskivezetés közti kapcsolat egyértelműen az innovációban rejlik. Továbbá, mivel kevés gyakorlat vonatkozik a szolgáltatásinnováció menedzselésére már meglévő ügyfélkapcsolatok esetében, ezért a vállalatok alternatív innovációs utakat keresnek (Gremyra \& Witell, 2013). A szolgáltatáskivezetés lehet az alternatív megoldások egyike, ha a vállalat a folyamatot megfelelőképpen menedzseli.

Az innovációnak számos definíciója létezik, a legtöbb annak folyamat jellegét emeli ki. Az egyik legelső definíciót Thompson (1965) alkotta meg: “Az innováció az új ötletek, folyamatok, termékek vagy szolgáltatások elöállitása, elfogadása és megvalósitása" (Thompson, 1965, 2. o.). Kimberly (1981) az innováció különböző szakaszait emeli ki: “Az innovációnak három szakasza van: innováció mint folyamat, innováció mint egy diszkrét elem a termékeket, programokat és szolgáltatásokat is beleértve; és az innováció mint a szervezetek egy tulajdonsága” (Kimberly, 1981, 108. o.). Damanpour (1996) az innovációhoz kötődő változást hangsúlyozza, amely széles körben elfogadott: “Az innováció a szervezet megváltoztatásához kötődö eszköz, amely vagy a külső környezetben bekövetkezö változásokra adott reakció, vagy a környezet befolyásolását megelőzö tevékenység. Ezért az innováció definíciója széles körü, számos típust magába foglal, mint például az új termék vagy szolgáltatás, új folyamat technológia, új szervezeti struktúra, adminisztrációs rendszer, vagy új tervek vagy programok, amelyek a szervezet tagjait érintik”" (Damanpour, 1996, 694. o.).

Régi vita tárgya annak eldöntése, hogy a szolgáltatásinnováció különbözik-e a termékinnovációtól, hasonlóan a termékek és szolgáltatások közötti vitához. Nijssen és szerzőtársai (2006) szerint a fő különbség a két fogalom között az, hogy szolgáltatásfejlesztés esetén a belső szervezeti tényezők fontosabbak, mint termékfejlesztés esetén. Edvardsson és Olsson (1996) hozzáteszik, hogy “nem magát a szolgáltatást állítják elö, hanem a szolgáltatás elöfeltételeit” (Edvardsson \& Olsson, 1996, 1476. о.).

Schumpeter (1934) az innováció két eltérő folyamatát különbözteti meg. Az első egy kreatív megsemmisítés, amelyet azok a vállalatok alkalmaznak, akik korábban nem innováltak, ezért ezt az innováció „szélesíto”” (widening) típusának nevezik (1-es típus). A másik a kreatív felhalmozódás, amelyet a már korábban is innováló vállalatok alkalmaznak, ezért ez az innováció „mélyítő” (deepening) típusa (2-es típus).

Habár számos definíció létezik, amelyek az innováció különféle aspektusait hangsúlyozzák, nincs egy általánosan elfogadott (Gopalakrishnan \& Damanpour, 1997). Közös koncepciók azonban vannak, amelyek fellelhetőek a különböző megközelítésekben, 
mint például az új ötletek vagy folyamatok generálása. Gopalakrishnan és Damanpour (1997) az innovációs szakirodalom öt csoportját azonosítják: közgazdaságtani, kontextuális és szervezeti technológusok, variancia és folyamat szociológusok. Az innovációk típusát tekintve nem nevezik meg a szolgáltatásokat, kizárólag a termékeket, mivel a szolgáltatásokat minden csoport a termék részeként tekinti.

A termékek és a szolgáltatások közti fö különbségeket a HIPI-elvvel (Zeithaml et al., 1985; Johne \& Storey, 1998) írhatjuk le, amelyet a 2.1-es fejezetben mutattunk be részletesen. A vállalati teljesítmény tekintetében azonban felfedezhetőek bizonyos különbségek: az innováció radikalitása pozitívan hat a vállalati teljesítményre, és kissé erősebben szolgáltatások, mint termékek esetében (Nijssen et al., 2006). A változékonyság, megfoghatatlanság, tárolhatatlanság és elválaszthatatlanság miatt a szolgáltatásinnováció rendszerint a folyamatokat és eljárásokat tekintve jár főként apróbb változtatásokkal, de ezáltal könnyebben másolhatóvá is válnak a versenytársak számára (Atuahene-Gima, 1996).

A szolgáltatás ökoszisztémákban az innováció a közösségi gyakorlatok és folyamatok eredménye, ahol a technológia egyrészt egy eredmény, másrészt az értékteremtéssel összefüggő co-creation és innováció közti közvetítőnek is tekinthető (Vargo et al., 2015). A legtöbb esetben az innováció kapcsolódik a technológiához, mivel az új technológiai fejlesztések segítenek az emberek problémáira megfelelő megoldásokat találni.

A technológia alapú szolgáltatásinnovációhoz szükség van az innováció elfogadására, amellyel kapcsolatban a legelterjedtebb modellek a DOI, az innováció elterjedési modell (diffusion of innovations) (Rogers, 1985), és a TAM, a technológia elfogadási modell (technology acceptance model) (Davis, 1989). Az ügyfelek új technológiák használatától való elbizonytalanodását okozó tényezőket ITU (inhibitors of technology usage)-nak, vagyis a technológia használatát gátló tényezőknek hívjuk. Általánosságban elmondható, hogy a személyes kapcsolat, bizalom és biztonságérzet hiánya okozzák az ügyfelek önkiszolgáló rendszerek használatában való bizonytalanságát (Cenfetelli \& Schwarz, 2011).

Habár az innováció definícióját tekintve számos, szerteágazó vélemény létezik, abban egyetérthetünk, hogy mindegyik valamilyen formában valami újnak a létrehozásához kötődik, amely egyértelmủen kapcsolható a szolgáltatáskivezetéshez: a szolgáltatások kivezetése által a vállalati erőforrások átalakulnak, és ezáltal segítik az új szolgáltatások fejlesztését.

A szolgáltatáskivezetés és a jelenlegi szolgáltatáskutatási prioritások kapcsolatában a másik átfogó koncepció a co-creation. Ennek fő oka, hogy az ügyfelek szolgáltatáskivezetési folyamatba történő bevonása a kivezetést követő lemorzsolódás csökkentésének egyik módja 
lehet. Az ügyfeleknek aktívan részt kellene venniük a folyamatban, egészen a kivezetendő szolgáltatások azonosításától kezdve, mivel így elkerülhetővé válhatna az ügyfél számára váratlan döntés végrehajtása. Például, ha egy olyan szolgáltatás kerül kivezetésre, amely az ügyfél számára jelentős hozzáadott értéket képvisel, de nem egyedi a piacon, akkor az ügyfelek nagy valószínűséggel elhagyják a vállalatot, miután a szolgáltatás a meglévő szolgáltatónál már nem elérhető számukra. Az ügyfelekkel való folyamatos kapcsolattartás segíthet az ilyen helyzetek elkerülésében, a preferenciáik alapos megismerésén keresztül.

Ahogyan a szolgáltatás-domináns logika is kiemelte, az ügyfelek a szolgáltatások előállításának aktív részesei (Vargo \& Lusch, 2004; Vargo \& Lusch, 2008). Az ügyfelek részvétele meghatározza a co-creation értékteremtését, ezért elengedhetetlen az ügyfelek bátorítása az értékteremtési folyamatban való részvételre (McColl-Kennedy \& Sparks, 2003). A szolgáltatáskínálat-menedzsment a vállalat és ügyfelek közti integráció által növeli az ügyfélértéket.

Grönroos és Voima (2013) az ügyfél szerepét a co-creation folyamatában értékteremtési szemszögből emeli ki: „Az ügyfél állitja elö az értéket a közvetlen interakció során, de ahogyan a szolgáltatót invitálja a folyamatba (amely egy közös dialógus folyamata), az értéket már együtt hozzák létre a szolgáltatóval” és a szolgáltató szerepét úgy határozzák meg, hogy „a szolgáltató lehetöséget kap arra, hogy részt vegyen az ügyfél értékteremtési folyamatában (co-creator)" (Grönroos \& Voima, 2013, 9. o.). Ez azt jelenti, hogy az ügyfél co-designer és co-developer (társ-fejlesztő) lehet a szolgáltatás előállítási folyamatban. Ezáltal mind a vállalatnak, mind pedig az ügyfélnek több lehetősége nyílik, hogy egymás értékteremtési folyamatát befolyásolják. A vállalat az ügyféllel együtt kínál értékajánlatokat, az ügyfél értékteremtését befolyásolva.

Prahalad és Ramaswamy (2004) a co-creation-t úgy definiálják, hogy a „, vállalat és az ügyfél közös értékteremtése” (Prahalad \& Ramaswamy, 2004, 8. o.). Emellett az interakció főbb blokkjait is meghatározzák: dialógus, hozzáférés, kockázatok, hasznok és transzparencia. A hagyományos koncepcióval ellentétben a co-creation szerint a piac több, mint az értékcsere (termékek és szolgáltatások) színtere, hiszen az érték elválaszthatatlanná válik az értékteremtési folyamattól, mivel a vállalat és a fogyasztók együttmüködnek az érték előállításában. Vagyis a piac sokkal inkább egy fórum, ahol a vállalat és a fogyasztók találkoznak.

A szolgáltatások fokozatosan egyre interdiszciplinárisabbá váltak. A marketingkutatók is folyamatosan keresték a más területekkel való kapcsolatokat, először az emberierőforrás- 
menedzsmenttel, majd a termelésmenedzsmenttel. Egy tanulmány szerint 24 akadémiai terület foglalkozik szolgáltatáskutatással a szolgáltatás terület koncepcionális keretén belül (Spohrer et al., 2014). Ez a kutatás többek között azt is kiemeli, hogy szükség van egy interdiszciplináris szolgáltatás megközelítésre, amely a szolgáltatási rendszerek fejlesztésére összpontosít, különösképpen a co-creation-re.

A telekommunikációs piacok új szolgáltatásfejlesztési folyamata a végfelhasználók ötletgenerálásba való bekapcsolódását emeli ki a technológia alapú önkiszolgáló rendszerek esetében, vagyis a co-creation valóban elkerülhetetlen. Ezek alapján a szolgáltatóknak már az innovációs folyamat korai szakaszaiba érdemes lenne bevonniuk az ügyfeleket, hogy a látens ügyféligényeket is feltárhassák (Matthing et al., 2004). Johne és Storey (1998) az ajánlat (offer) fejlesztését hangsúlyozzák a szolgáltatásfejlesztésen belül, amely azt jelenti, hogy nem az egész terméket vagy szolgáltatást fejlesztik, hanem csak az ajánlat egy részét, vagy a fö szolgáltatáshoz kapcsolódó kiegészítő szolgáltatást.

Miután áttekintettük a nemzetközi szolgáltatáskutatási trendeket, és azok kapcsolatát a szolgáltatáskivezetéssel, úgy érezzük, hogy fontos a szolgáltatáskutatás magyarországi állapotának a feltárása is, hiszen tanulmányunk egy része ezt a kontextust vizsgálja. A következő fejezetben tehát a magyarországi trendeket mutatjuk be.

\subsubsection{A MAGYAR SZOLGÁLTATÁSKUTATÁS TRENDJEI 1992-2016 KÖZÖTT}

A szolgáltatások kutatása ma már több évtizedes múltra tekint vissza, mind a hazai, mind pedig a nemzetközi szakirodalomban. 1977-ben jelent meg Shostack írása a Journal of Marketingben, „Breaking free from Product Marketing” címmel (Shostack, 1977), melyben a szolgáltatások megkülönböztető marketingjellemzőire hívta fel a figyelmet. Az elmúlt évtizedekben a szolgáltatások kutatása önálló diszciplínává nőtte ki magát, amit a témával foglalkozó szaklapok, cikkek, szakkönyvek, konferenciák növekvő száma is jelez.

E változásokat elősegítette a szolgáltatószektor gazdasági súlyának növekedése; ma már a fejlett országok GDP-jének közel kétharmadát a szolgáltatószektor adja (The World Bank, 2017). Jelentősen megváltozott az üzleti környezet is, elsősorban a technológia szerepének előtérbe kerülésével (Internet of things, mobil technológia, big data, stb.), alapjában véve rendeződött át a fogyasztó és a vállalat kapcsolatrendszere (Kenesei \& Kolos, 2016).

A szolgáltatáskutatás fentiekben felvázolt erősödése meglátásunk szerint ugyanakkor Magyarországon csak kevéssé vagy csak egyes speciális területeken érezteti hatását. 
Elemzésünkkel fő célunk, hogy áttekintést adjunk a hazai szolgáltatáskutatás elmúlt közel 25 évének jellemzőiről, fejlődési irányairól és javaslatot tegyünk a hazai üzleti környezethez leginkább illeszkedő kutatási lehetőségekre.

Elemzésünkhöz a Vezetéstudomány és Marketing \& Menedzsment szolgáltatás témájú, 1992-2016 között megjelent, összesen 96 cikkét használtuk fel. Azért választottuk ezt a két folyóiratot, mert mind a marketing, mind más tudományos diszciplína kutatói számára meghatározó és elismert tudományos forrásnak számítanak.

A szakirodalom feldolgozása minden szolgáltatás témában publikált cikket tartalmaz, az említett folyóiratokban. A cikkeket megjelenési év, a publikáció fő témája, a vizsgált szektor és alkalmazott módszertan szerint osztályoztuk. A cikkeket ezután tartalomelemzéssel elemeztük a téma, kutatási kérdések, alkalmazott módszertan és főbb eredmények meghatározására.

A két folyóirat szolgáltatás témában 96 megjelent cikkét összesen 135 szerző publikálta. Szembetűnő, hogy a Marketing \& Menedzsmentben 1999-ben kiugróan magas számú szolgáltatásokhoz kapcsolódó cikk jelent meg, míg a Vezetéstudományban a 2009-es év kiemelkedő. A cikkek számát tekintve elmondhatjuk, hogy szolgáltatás témában a Vezetéstudományban több cikk jelent meg a vizsgált időszak alatt (37 a Marketing és Menedzsmentben és 59 cikk a Vezetéstudományban).

Cikkünkben az általános trendek vizsgálata után három fő korszakot azonosítunk, majd ez alapján határozzuk meg a jövőbeli kutatási irányokat.

A szolgáltatásirodalom elemzése során két fő szempontot vizsgáltunk:

1. Tudományos kérdésfeltevés: olyan iparágtól független témák, amelyek a szolgáltatások sajátosságaival kapcsolatosak, pl. szolgáltatásminőség mérése.

2. Alkalmazott módszerek: a szakirodalom az alkalmazott módszerek terén eléggé vegyes képet mutat, a kutatási terület határozza meg elsősorban a választott módszer típusát.

A trendeken belül a kutatási témák népszerüsége szerint elemezzük a cikkek általános témáit (2. táblázat).

2. táblázat: A Marketing \& Menedzsment és Vezetéstudomány szolgáltatás témájú cikkeinek kutatási témái (1992-2016)

Kutatási téma

Szolgáltatásmarketing

Piaci szereplők és mechanizmusok

Szolgáltatásminőség

Termelés és szolgáltatás

Ügyfél és szolgáltatóvállalat kapcsolata

Cikkek száma a vizsgált időszakban (1992-2016)

\section{1}

20

16

11

9 
Tudásmenedzsment 3

Szervezeti struktúra 3

Outsourcing 3

Vállalatok közti együttmüködés $\quad 2$

ICT szerepe a szolgáltatásoknál 2

Pénzügyi magatartás $\quad 2$

Projektmarketing 2

Teljesítménymérés 2

\section{Forrás: saját szerkesztés}

A legkutatottabb téma a szolgáltatásmarketing, amely leginkább a '90-es évek közepétől 2000-ig lett hangsúlyos téma és föként elméleti konstrukciókban jelent meg (Vályogos, 1994; Bányai, 1995; Bányai, 1995; Ványai, 1996; Gyöngyösy, 1998; Veres, 1998). Az egyik kutatási irányzat ezen belül a marketing alapfogalmainak értelmezése a szolgáltatások esetére. Ilyen kérdésfeltevés például a marketingmenedzsment és a marketingkoncepció adaptálása az üzleti szolgáltatásokra (Vályogos, 1994), a vevőorientáció érvényesítése (Kolos \& Berács, 1999) vagy a szekunder szolgáltatások kapcsolata a primer szolgáltatásokkal (Várady, 1994).

A fogyasztói magatartás egyes kérdései is hangsúlyosan jelentek meg, hiszen a szolgáltatásmarketing abból a felfogásból született, hogy a szolgáltatások vásárlásáról másként döntenek a fogyasztók, leginkább annak megfoghatatlan jellege miatt. Így az értékelés, a döntés magasabb észlelt kockázattal párosul. Ehhez a gondolatkörhöz kapcsolódó témák a fogyasztói szolgáltatások értékelési, választási szempontjai szolgáltatástípusonként (Kolos \& Demeter, 1995), az elégedettség- vizsgálatok fontossága (Koósa, 2001), lojalitásmérés (Hetesi \& Rekettye, 2001), a vásárlók megtartásának fontossága (Farkas, 2003), a kedvezőtlen szolgáltatásélmény elemzése (Ercsey, 2004), a szolgáltatások megtervezése (Gyöngyösy, 1999; Heidrich, 2006), a kapcsolati marketing és kommunikáció (Hetesi \& Révész, 2004; Fiáth et al., 2010).

Harmadsorban pedig egyes alkalmazási területek kerültek a kutatók érdeklődésének középpontjába, mint például a marketing a közszolgáltatásoknál (Dinya, 1999), illetve a turisztikában (Nemeskéri, 1999), az ipari szolgáltatások jelentősége (Vágási, 1999), hitelintézeti marketingtevékenység (Varga \& Fojtik, 2004). Végül pedig néhány módszertani írás is megjelent, mint például a próbavásárlás lehetőségeinek és módszereinek feltárása (Durugy et al., 2016).

A piaci szereplők és mechanizmusok közé soroltuk a közszolgáltatások sajátosságait (Jenei, 1997; Marián, 2001; Schwartz, 2006; Somogyi, 2006; Pásztor, 2008; Jobbágy, 2010; Jenei \& Kuti, 2011; Takács, 2015), az oktatáspolitikát és a továbbképzési rendszer átalakítását 
(Jenei \& Kemenes, 1992; Hetényi, 1992; Kemenes \& Váradi, 1992), valamint a 2000-es évektől megjelenő, a piaci versenyt (Ercsey, 2000), menedzsment kérdéseket (Jenei, 2000) és versenyképességet (Horváth, 2012) bemutató írásokat. Emellett a pénzügyi szektor is megjelenik, elsősorban a pénzügyi szektor sajátosságait bemutató elméleti írásokkal (Hámori, 1994; Németh, 1995; Ványai, 1997; Fazekas \& Tóth, 1998; Incze, 2013).

A szolgáltatásminőség iparágtól függetlenül, elméleti cikkekben (Papp, 1995; Kovács, 2000; Papp \& Rózsa, 2003; Veres, 2008), és empirikus vizsgálatoknál a pénzügyi szektorban (Párkányi, 1996; Kenesei \& Szántó, 1998; Fojtik \& Farkas, 2001), vendéglátásban (Kenesei \& Kolos, 2008), egészségügyben (Vajda, 2014) és kulturális szolgáltatásoknál (Somogyi, 2013; Ercsey, 2014) is helyet kap. A vizsgálatok fö célja a szolgáltatásminősítés módszereinek (pl. SERVQUAL) azonosítása (Kenesei \& Szántó, 1998; Becser \& Paprika, 2004; Vajda, 2014), a szolgáltatás és vevői elégedettség összefüggéseinek vizsgálata (Kovács, 2000; Somogyi, 2013) és az ehhez kapcsolódó panaszkezelés hatékonysága (Kenesei \& Kolos, 2008), valamint a gap elemzés (a szükséglet és kialakuló elégedettségi állapot között) (Veres, 2008). Ezek mellett a minőségmenedzsment, TQM is megjelenik (Salamon, 2011).

A másik ilyen viszonylag átfogó téma, hogy ebben a változó időszakban hogyan tolódik el az egyensúly a szolgáltatások irányába, és melyek a fö különbségek a termékek és szolgáltatások között. Ebben a témában mind elméleti (Gyöngyösy, 1999; Demeter \& Gelei, 2002; Heidrich \& Somogyi, 2003; Heidrich \& Somogyi, 2005; Koltai et al., 2009), mind a szolgáltató és termelővállalatok összehasonlításával végzett empirikus cikkeket is találunk (Chikán \& Demeter, 1994; Letenyei \& Papp, 2005; Demeter, 2009; Demeter, 2009; Gelei \& Gémesi, 2010; Demeter \& Szász, 2012; Bálint, 2014). Ezek szinte kivétel nélkül a termelési és szolgáltatási tevékenység közti különbségeket vizsgálják eltérő kontextusban, az ellátási láncok különbségeivel kiegészítve (Gelei \& Gémesi, 2010).

Az ügyfél és szolgáltatóvállalat kapcsolata témában a szerzők az ügyfél aktív részvételét hangsúlyozzák (Hans-Reinhard et al., 1996; Kenesei, 1996; Osman, 1997; Takács, 1998; Veres, 1998; Gyöngyösy, 1999; Németh, 1999, Pintér, 2004), amely növeli a bizalmat a szolgáltatásokkal kapcsolatban és ezáltal a piaci részesedésre is hatással van (Takács, 1998).

Az informatikai outsourcing megjelenésével a fogalmat bevezető elméleti cikk mellett (Drótos, 1995) könyvtárak (Mikulás, 1998) és SSC-k (shared service center) (Szabó \& Vida, 2009) szekunder elemzésével foglalkoztak a szerzők.

Újabb keletü témák az ICT szerepe a szolgáltatásoknál és a tudásmenedzsment (Berács, 2006; Dobrai \& Farkas, 2009; Kővágó, 2014), amelyeket csak a 2000-es évektől kezdenek 
vizsgálni. Az ICT szerepe a szolgáltatásoknál témán belül az internetoldalak és honlapok minősége (Rekettye \& Pintér, 2006), és az ICT turisztikai alkalmazása (Grotte, 2010) jelent meg.

A vállalatok müködésével összefüggésben több altémát tudtunk azonosítani: szervezeti struktúra, amelyen belül a szakirodalom a szolgáltatásminőség belső szervezeti összefüggéseit (Heidrich \& Somogyi, 2003), az üzletági szervezeti struktúra kialakítását (Pandurics \& Pusztai, 2006), és az ügyfélszolgálatok HR kérdéseit (Fehér \& Bencsik, 2007) vizsgálja; és a projektmarketing (Mandják, 1995; Veres \& Sajtos, 2011), amely a projektjellegü szolgáltatások észlelt értékével és kockázatával foglalkozik. A vállalatok közötti együttmüködés kapcsán a bankok és biztosítók közti speciális együttmüködési formát, a bankbiztosítást (Pintér, 2002; Szüle, 2006) mutatják be a szerzők, valamint a szervezeti teljesítménymérés és -értékelés, valamint az üzleti teljesítmény közti kapcsolatot a víziközmü vállalatok alapján (Székely, 2007), és a szakpolitika-alapú kormányzásban (Jobbágy, 2010) elemzik. Emellett a pénzügyi magatartás a kontrollosság és a pénzügyi attitűd vizsgálatával jelenik meg (Mihály et al., 2014; Zsótér et al., 2015).

Az alkalmazott módszerek időbeli alakulását mutatja a 4. ábra, amelyen a kvantitatív módszerek előtérbe kerülése látható a 2000-es éveket követően, míg a vizsgált időszak kezdetét inkább az elméleti jellegü cikkek határozták meg.

\section{4. ábra: A Marketing \& Menedzsment és Vezetéstudomány szolgáltatás témájú cikkeinek alkalmazott módszerei (1992-2016), N=96}

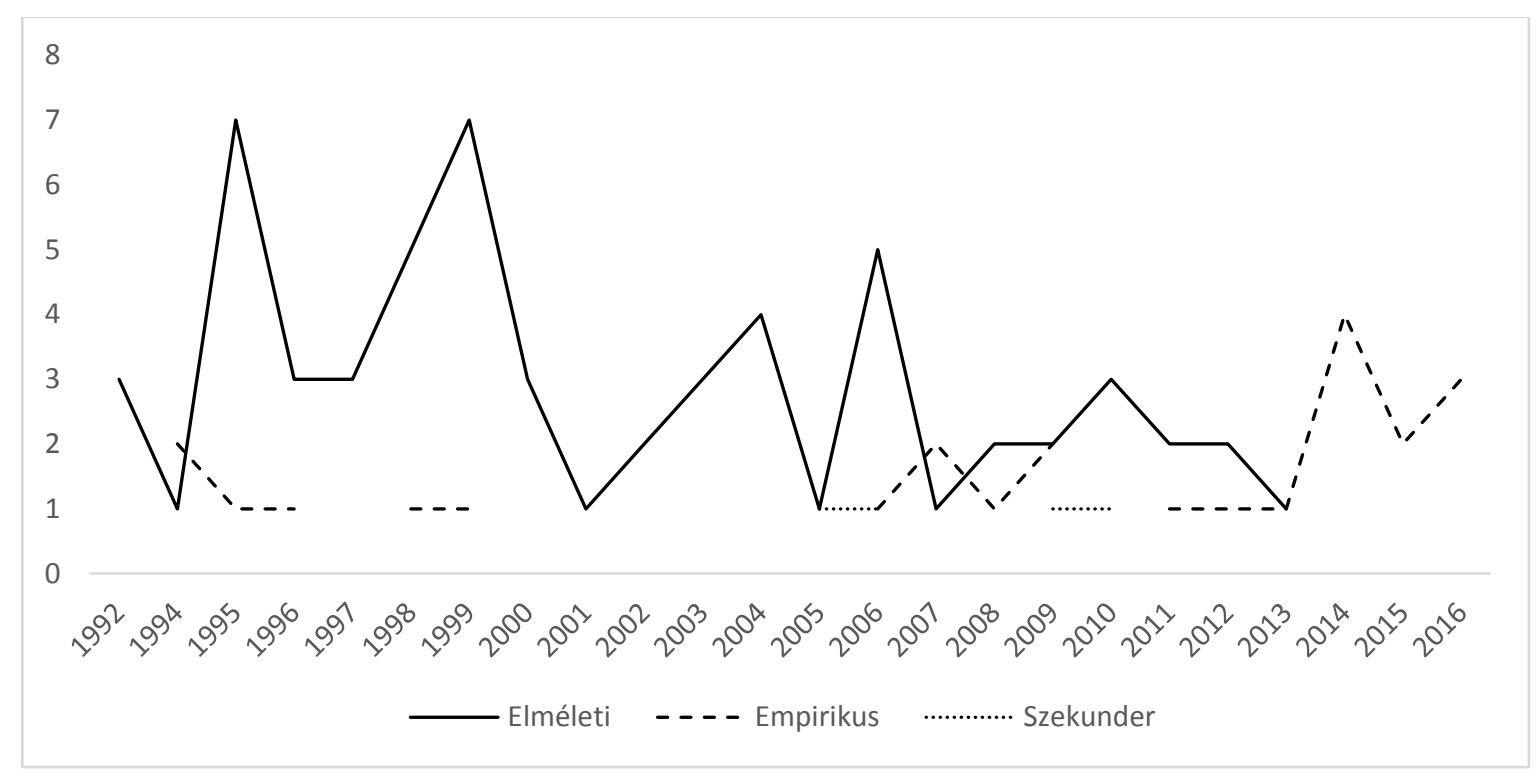

\section{Forrás: saját szerkesztés}

Az 5. ábra világít rá az egyes területekhez kapcsolódó módszertani specifikumokra. Mindegyik területen túlsúlyban vannak az elméleti írások, amely talán annak köszönhető, 
hogy a nemzetközi szolgáltatás trendeket értelmezik sokszor a szerzők hazai környezetben. A piaci szereplők és mechanizmusok témában mégis érdekes, hogy az elméleti cikkeken kívül alig látunk mást, míg a termelés és szolgáltatás téma a legsokszínübb módszertani szempontból, vélhetőleg azért, mert a termékek és szolgáltatások közti különbségek a fogalmak definiálásán túl jól tesztelhetőek empirikusan is. Az ügyfél és szolgáltatóvállalat kapcsolatának vizsgálatában szintén az elméleti cikkek túlsúlya jellemző. Empirikus tanulmányokat főként a szolgáltatásminőség és szolgáltatásmarketing témakörökben találunk.

\section{5. ábra: A Marketing \& Menedzsment és Vezetéstudomány szolgáltatás témájú} cikkeinek alkalmazott módszerei, fő témák szerinti csoportosításban (1992-2016), N=96

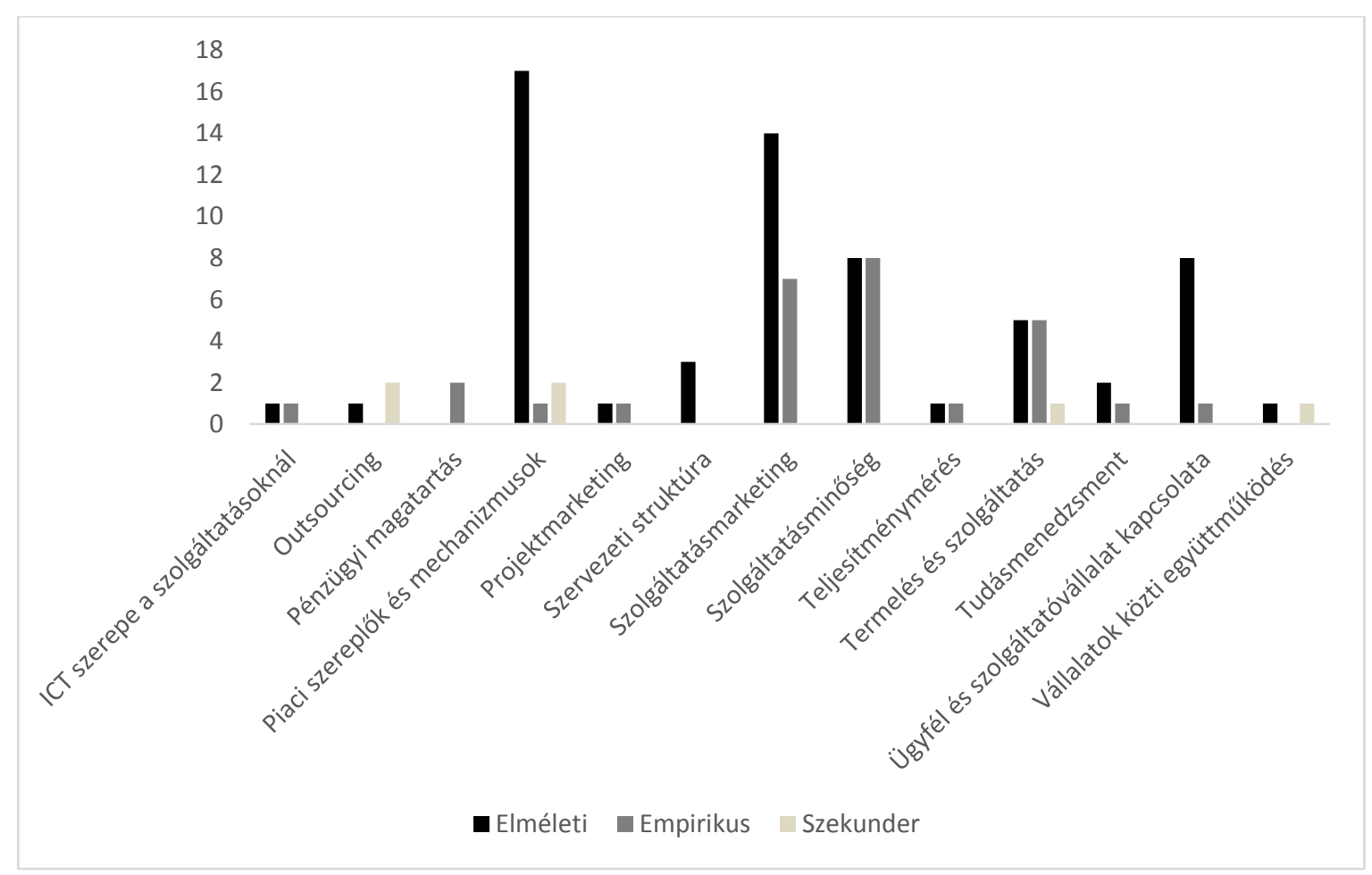

Forrás: saját szerkesztés

A hazai szolgáltatáskutatás fejlődésének vizsgálatát jellemző szakaszok meghatározásával folytattuk. A vizsgált cikkek tartalma alapján kerestük a közös elemeket és meghatározó fordulópontokat. Az elemzés során három fő korszakot azonosítottunk, amelyek a következőek:

\section{1992-1999- „A Kezdetek”}

A hazai szolgáltatás szakirodalmat kezdetben a piaci szereplőket és mechanizmusokat bemutató témák túlsúlya jellemezte, elsősorban elméleti cikkekkel, amelyek a közszolgálati továbbképzések fontosságára hívták fel a figyelmet (Jenei \& Kemenes, 1992; Hetényi, 1992; Kemenes \& Váradi, 1992). Emellett megjelent a szolgáltatásmarketing, eleinte szintén elméleti, a fogalmakat és alapmodelleket definiáló cikkekkel (Vályogos, 1994; Bányai, 1995). 
Ehhez kapcsolódóan felvetődött a szolgáltatásminőség kérdésköre (Veres, 1995), illetve a minőségmodellek bemutatása (Kenesei \& Szántó, 1998). Szintén a szolgáltatásmarketing alapfogalmaihoz kötődik a fogyasztói elvárások vizsgálata (Kolos \& Berács, 1999; Kolos \& Demeter, 1995). Az ügyféllel való szorosabb kapcsolat kialakítása, az aktív ügyfél politikát hangsúlyozása szintén jellemző a korszakra (Hans-Reinhard et al., 1996; Kenesei, 1996; Osman, 1997; Takács, 1998; Veres, 1998; Németh, 1999).

\section{2000-2009 - „Minőség-fókusz”}

A szolgáltatásminőség a vállalatok versenyképességének egyre meghatározóbb tényezőjévé vált, és ezzel párhuzamosan megjelentek a minőség méréséhez kötődő módszerek, mint például a TQM (Papp \& Rózsa, 2003; Salamon, 2011), a szolgáltatásmarketingben pedig a SERVQUAL skála hazai adaptálása, az ügyfél elégedettség és lojalitás mérésével összefüggésben (Becser \& Paprika, 2004; Hetesi \& Rekettye, 2001). A minőségméréssel összefüggésben kapott nagyobb hangsúlyt a panaszkezelés kutatása (Kenesei \& Kolos, 2008), és a kritikus esetek módszerének alkalmazása (Kolos \& Berács, 1999).

\section{2010- „A szolgáltatáskutatás diverzifikációja”}

2010 után a nemzetközi szakirodalomhoz hasonlóan némileg érzékelhető a szolgáltatások kontextusának kiterjesztett értelmezése. Ezen belül a szolgáltatások és termékek (Demeter \& Szász, 2012; Bálint, 2014), az azokat előállító vállalatok és ellátási láncaik közötti eltérések (Gelei \& Gémesi, 2010), illetve a hozzájuk kapcsolódó rendszerek optimalizálása válnak fontos kutatási kérdésekké.

A nemzetközi szakirodalomban hangsúlyosan megjelenő kutatási prioritások megjelenése szintén jellemző erre az időszakra, mint például a szolgálatosodás (Bálint, 2014; Demeter \& Szász, 2012), közös értékteremtés és kultúra (Ercsey, 2014), valamint a tudásintenzív üzleti szolgáltatások (Kővágó, 2014).

Egyre népszerübbé váltak a fogyasztói elégedettség vizsgálatok, amelyek megalapozták a kvantitatív módszerek elterjedését (Somogyi, 2013; Vajda, 2014; Ercsey, 2014).

Szükebb kutatási témák is megjelentek, mint például a pénzügyi kultúra és attitüd (Mihály et al., 2014; Zsótér et al., 2015), észlelt kontroll és érzelmek szerepe (Kenesei \& Kolos, 2016), kompenzáció (Kenesei \& Szilvai, 2016); vagy speciális, eddig kevésbé vizsgált alkalmazási területek, mint például gazdasági kamarák (Fülöp, 2012) vagy a távfütés szerepe (Horváth, 2012). 
A korszakok közötti tematikus eltéréseket a 6. ábra szemlélteti. Az ügyfél és szolgáltatóvállalat kapcsolatában csökkenő tendencia figyelhető meg, a piaci szereplök és mechanizmusok téma ezzel szemben viszonylag konstans a teljes időszak alatt (6. ábra).

\section{6. ábra: A Marketing \& Menedzsment és Vezetéstudomány szolgáltatás témájú}

cikkeinek áttekintése a 3 fő korszakban, fő témák szerint (1992-2016), N=96

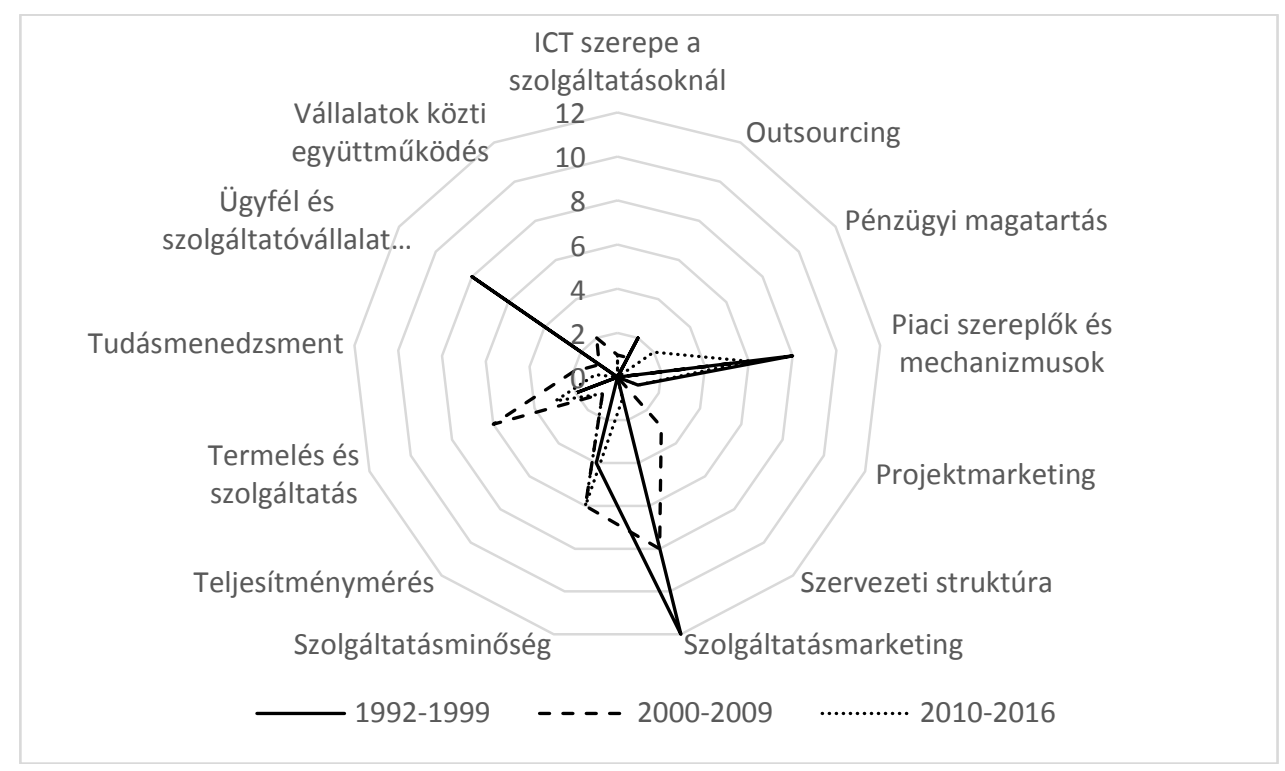

Forrás: saját szerkesztés

A három fó korszakot áttekintve látható, hogy a hazai szolgáltatáskutatásokban a szolgáltatásminőség témája az elmúlt 25 évben kiemelt szerepet kapott. Noha hangsúlyosan a 2000-2009 közötti időszakban állt a kutatók érdeklődési körében, kisebb-nagyobb mértékben mindhárom időszakban megjelenik, mint kutatási téma. Várható, hogy a jövőben a minőség mérésének új módszerei jelenhetnek meg, amely a technológiai környezet gyors változásával vélhetően hamar elterjedhetnek Magyarországon is. Ezek lehetnek például a big data-hoz kapcsolható adatbányász módszerek (pl. Python).

A nemzetközi trendeken belül (Ostrom et al., 2015) ez beleillik a szolgáltatás teljesítmény mérése és optimalizálása témakörbe, amely várhatóan a hazai szakirodalomban is hangsúlyos téma lesz.

Érdemes erősíteni az interdiszciplináris megközelítések alkalmazását. A vizsgált időszak kutatásai is többféle tudományterületet jelenítenek meg (marketing, termelésmenedzsment, informatika, közszolgáltatások, vállalkozásfejlesztés stb.). Azonban az egyes publikációk jellemzően egy tudományterület határain belül maradnak. Véleményünk szerint gazdagítaná a hazai szolgáltatáskutatás fejlődését az interdiszciplináris kutatócsoportok, mühelyek kialakulása. A nemzetközi szakirodalomban kutatási prioritásként megjelölt témakörök nagyrészt e felfogásban kezelhetők; nagyobb hangsúlyt kellene kapnia a 
jövőben a design és a szolgáltatásinnováció kapcsolatának, a szolgáltatások szervezeti kérdéseinek (szervezeti kultúra, alkalmazottak szerepe), és nem utolsósorban a digitalizáció hatásának vizsgálata (mobil technológia, okos szolgáltatások) a lakossági és üzleti piacokon egyaránt.

A hazai szolgáltatáskutatásban eddig explicit módon nem jelent meg a transzformatív szolgáltatáskutatás. Ez a kutatási terület a szolgáltatások és a társadalmi/ egyéni jóllét közötti kapcsolatot vizsgálja. Kiemelt kontextusnak számít az egészségügy és az oktatás: hogyan lehet ezek minőségét és az emberek hozzáférését javítani ezekhez a szolgáltatásokhoz? Hogyan lehet a szolgáltatások nyújtásánál a fenntarthatósági szempontokat érvényesíteni?

Összegzésként megállapíthatjuk, hogy a szolgáltatások kutatásának Magyarországon jelentős hagyománya van, és a további kutatási lehetőségeket tekintve is kedvezőek a kilátások. A további fejlődéshez azonban nélkülözhetetlen az interdiszciplináris megközelítés és a nemzetközi kutatási hálózatokba való hangsúlyosabb bekapcsolódás. 


\subsection{SZOLGÁLTATÁSKIVEZETÉS}

A szolgáltatásmarketing szakirodalom és a jelenlegi kutatási prioritások áttekintését követően fö témánkkal, a szolgáltatáskivezetéssel foglalkozunk.

Az első fejezetben a szolgáltatáskivezetést egy olyan folyamatként definiáltuk, amikor a szolgáltató a meglévő szolgáltatásait úgy vezeti ki, hogy a meglévő ügyfeleit új szolgáltatáscsomagokra irányítja át. A kutatásunk szempontjából ezen kívül fontos megjegyezni, hogy kutatásunk során a részleges kivezetést (partial elimination) vagy a szolgáltatás lezárást (service closing) definíció szinten nem tekintjük szolgáltatáskivezetésnek. A szolgáltatáskivezetés számos megközelítése közül (Argouslidis, 2001) kutatásunkban az úgynevezett teljes kivezetést vizsgáljuk (full elimination), amely azt jelenti, hogy a meglévő szolgáltatások kivezetésre kerülnek és az összes érintett ügyfelet új szolgáltatáscsomagokra irányítja át a szolgáltató vállalat.

Választásunk azért esett a kivezetésnek erre a típusára, mert többek között ez a szolgáltatáskivezetés legkevésbé kutatott területe. A teljes kivezetés (full elimination) vagy néha „core product” (fö termék) (Harness \& Mackay, 1997) kivezetésként is használt fogalom arra az összetett, gyakran veszélyes stratégiára vonatkozik, amely során az ügyfelek lemorzsolódásának kockázata kiemelten magas. A másik tényező, amely jelentősen befolyásolja ezt a kockázatot, az a migráció típusa (önkényes vagy kényszerített). A kényszerített migráció esetén ez a kockázat a legmagasabb. A gyakorlati tapasztalat azt mutatja, hogy a 20-30\%-os lemorzsolódás a telekommunikációs szektorban átlagosnak számít szolgáltatáskivezetés esetén (teljes kivezetés esetén, kényszermigrációval), viszont az ügyfélbázis közel egyharmadának elvesztése nem megengedhető, különösen nem stagnáló piacokon. Ezért sok vállalat a kivezetésnek ezt a formáját igyekszik elkerülni, és inkább a részleges kivezetés (partial elimination) mellett dönt (például szolgáltatás lezárást, amely során csak új ügyfelek számára nem elérhető a szolgáltatás a kivezetést követően; szegmensek előli lezárást, amely során csak bizonyos ügyfélszegmensek számára nem elérhető a szolgáltatáskivezetés után; egyszerűsítést, ahol a szolgáltatás egy része nem elérhető a szolgáltatáskivezetés után; vagy szolgáltatás összeolvasztást választ, ahol két vagy több szolgáltatást részlegesen vagy teljesen összevonnak a szolgáltatáskivezetés után, stb.), amellyel azonban csak részben elérhetőek el a teljes szolgáltatáskivezetés előnyei. Az erőforrások többek között továbbra is lekötve maradnak, vagyis a szolgáltatásportfólió komplexitása jelentősen nem csökkenthető néhány szolgáltatás részleges kivezetésével, vagy 
a szolgáltatások néhány szegmens elöli lezárásával. Ennek eredményeképpen a fenntartási és fejlesztési költségek továbbra is magasak maradnak, amely hátráltatja a szolgáltatásinnovációt.

Ezek alapján úgy gondoljuk, hogy a teljes kivezetés során fellépő magas ügyfél lemorzsolódási kockázat csökkentése érdekében ennek a speciális területnek a további vizsgálata elengedhetetlen, az empirikus eredmények gazdagítása és a vállalati gyakorlat támogatása érdekében.

A szolgáltatáskivezetés teljes folyamatának megértéséhez ebben a fejezetben a 2. ábrán bemutatott szerkezeti térképet követjük: elöször a szolgáltatáskivezetés és termékkivezetés kapcsolatát tekintjük át, majd ezt követően összegezzük a szolgáltatáskivezetés meglehetősen szük szakirodalmát, a lehetséges kutatási irányokat feltárva. A fejezet további része a szolgáltatáskivezetési folyamat három lépése (szolgáltatáskivezetés előtti szakasz, a szolgáltatáskivezetés implementációja és a szolgáltatáskivezetés utáni szakasz) alapján épül fel, a szolgáltatáskivezetés hatását magyarázó elméleteket is beleértve.

\subsubsection{A TERMÉKKIVEZETÉS ÉS SZOLGÁLTATÁSKIVEZETÉS KÖZTI KÜLÖNBSÉGEK}

A szolgáltatáskivezetés alaposabb megértése érdekében először a szolgáltatáskivezetés és termékkivezetés közti különbségeket tárjuk fel. Habár ez két különböző fogalom, van néhány sajátosság, amelyben hasonlónak tekinthetőek, amelyeket felhasználunk kutatásunk során.

A termékkivezetés nem más, mint „az a kivezetési folyamat, amikor egy szervezet egy olyan változást azonosit, amely megkérdőjelezi egy bizonyos termék piacon tartásának létjogosultságát" (Harness \& Harness, 2007, 198. o.), amely tulajdonképpen hasonló a szolgáltatáskivezetéshez a kivezetés fő okait, célját és lehetséges előnyeit tekintve.

A termékkivezetés stratégiai jelentőséggel is bír: „a termékkivezetés négy területen biztosit elönyöket a szervezet számára: a menedzsment és sales erőfeszitések egyszerüsitése/koncentrációja; a termékportfólió teljesitményének továbbfejlesztése; az ügyfélmenedzsmenttel kapcsolatos elönyök; a fizikai és pénzügyi eröforrás menedzsment javítása” Harness \& Harness, 2012, 56. o.). Harness és szerzőtársai (2012) elsősorban a termékkivezetés hatásait elemezték, de a pénzügyi szolgáltatások esetében hasonló eredményekre jutottak. Mindezek alapján ezeket a termék -és szolgáltatáskivezetés közös elönyeinek tekintjük.

A termékkivezetés területén számos, vállalati nézőpontú tanulmány született főként az alábbi témákban: 
- A termékkivezetési gyakorlat általános jellemzése (Avlonitis \& James, 1982; Avlonitis, 1983-1984; Eckles, 1971; Hise \& McGinnis, 1975; Hise et al., 1984; Greenley \& Bayus, 1994);

- A kivezetés előtti döntési folyamat: (Hart, 1988; 1989; Mitchell et al., 1997);

- A termékkivezetés döntéshozatali folyamata: a kivezetendő termékek azonosítása (Banville \& Pletcher, 1974; Avlonitis, 1986), elemzés és módosítás (Avlonitis, 1985c; Saunders \& Jobber, 1994), értékelés és döntéshozatal (Evans, 1977; Avlonitis, 1984, 1993; Saunders \& Jobber, 1994; Mitchell et al., 1997), implementáció (Avlonitis, 1983; Avlonitis, 1985c; Rothe, 1970; Avlonitis, 1993);

- Kivezetés utáni szakasz: teljesítmény eredménye (Avlonitis, 1987);

- Szervezeti és strukturális kérdések: részvétel (Avlonitis, 1985b): Avlonitis (1985b); a döntéshozatal struktúrája (i.e. formalization) (Avlonitis, 1985a), a döntés gyorsasága (Avlonitis, 1985a);

- Etikai megfontolások (Avlonitis, 1983; Hise \& McGinnis, 1975);

- A termékkivezetés és a termék-életciklus elmélet (Avlonitis, 1990);

- A termékkivezetési döntés tipológiája (Avlonitis et al., 2000);

- A termékkivezetés történelmi, szabályozási és gazdasági vonatkozásai (Rosegger \& Baird, 1987; Stavins, 1995; Greenstein \& Wade, 1998; Putsis \& Bayus, 2001; Hooker et al., 2002; Ruebeck, 2002; Hitsch, 2006).

A termékkivezetés kihívásokkal jár a menedzserek számára, nehezen hoznak ezzel kapcsolatban döntést elsősorban a termékkivezetés lojalitásra gyakorolt hatása miatt (Homburg et al., 2010). Ezt a problémát szolgáltatáskivezetés esetén is relevánsnak látjuk.

A kivezetés implementációja rendszerint jelentősen eltér szolgáltatások és termékek esetében: szolgáltatáskivezetés esetén a szolgáltató vállalat igyekszik ügyfeleit egy másik szolgáltatásra átirányítani (ezáltal helyettesítve a kivezetendő vagy már esetleg létező másik szolgáltatást) (Gounaris et al., 2006).

A termékkivezetés hátterében más tényezők is állhatnak: a kivezetést elsősorban a termék összességében gyenge teljesítménye (pl. visszaesés az eladásban), a termék portfólión belüli menedzsmentje, külső tényezők (pl. szabályozások) vagy limitált polchely indokolhatják (Harness \& Harness, 2007), a szolgáltatások esetében azonban ezeken kívül teljesen más tényezők is állhatnak a háttérben. Úgy gondoljuk, hogy a szolgáltatások esetében a kivezetés sokkal inkább a szolgáltatások rövid életciklusa és a szolgáltatóipar gyors portfólió innováció iránti igénye miatt indokolt. Ez egyúttal azt is jelenti, hogy a 
szolgáltatáskivezetési döntés a keresletmenedzsment része és az ügyfelek kivezetendő szolgáltatásról való átirányítását is jelenti (Harness \& Mackay, 1997).

A rövid termékéletciklus tehát a gyorsan változó innovációk eredménye, különösképpen a high-tech termékek esetében (Wu et al., 2006). A telekommunikációs szektorban hasonló trend figyelhető meg, a szolgáltatók folyamatosan újítják szolgáltatásaikat fenntartható versenyelőny megszerzése érdekében.

Mindezek alapján összegezzük a szolgáltatás-és termékkivezetés közti különbségeket B2C kontextusban (3. táblázat). A legfontosabb hasonlóságok a kivezetés fö okai, célja és előnyei, de fő témánkat, a szolgáltatáskivezetés sikerességét tekintve, a legfontosabb különbség a két fogalom között ebben a tekintetben az, hogy a termékkivezetés esetében nem történik kényszermigráció, mivel az ügyfelek és a szolgáltatóvállalat között nem áll fenn szerződéses kapcsolat (kizárólag a szolgáltatáskivezetés szerződéses formáját vizsgáljuk), így helyettesítő terméket vásárolhatnak. Ennek azonban közvetlen hatása van az ügyfél lemorzsolódásra, vagyis ezt a területet nem befolyásolják a termék- és szolgáltatáskivezetés között fennálló hasonlóságok.

\section{3. táblázat: A szolgáltatáskivezetés és termékkivezetés közti}

\section{hasonlóságok és különbségek}

\begin{tabular}{|c|c|c|}
\hline & Szolgáltatáskivezetés & Termékkivezetés \\
\hline A kivezetés fö okai & $\begin{array}{l}\text { - általános gyenge teljesítmény; } \\
\text { - } \quad \text { a szolgáltatás portfólión belüli } \\
\text { menedzsmentje; } \\
\text { - } \quad \text { rövid életciklus; } \\
\text { - } \quad \text { külső tényezők. }\end{array}$ & $\begin{array}{l}\text { - általános gyenge teljesítmény; } \\
\text { - } \text { a szolgáltatás portfólión belüli } \\
\text { menedzsmentje; } \\
\text { - rövid életciklus; } \\
\text { - külső tényezők; } \\
\text { - a retail hálózatban elérhetö limitált } \\
\text { polchelyek. }\end{array}$ \\
\hline A kivezetés célja & \multicolumn{2}{|c|}{ a meglévő ügyfelek új szolgáltatásra/termékre való átirányítása } \\
\hline Az ügyfél értesítésének módja & $\begin{array}{l}\text { az ügyféllel való közvetett/közvetlen } \\
\text { kommunikáció }\end{array}$ & $\begin{array}{l}\text { az ügyféllel való korlátozott } \\
\text { kommunikáció/ a kommunikáció hiánya }\end{array}$ \\
\hline $\begin{array}{l}\text { A kivezetés hatása a tárolási } \\
\text { költségekre }\end{array}$ & nem releváns & a tárolási költségek csökkenhetnek \\
\hline $\begin{array}{l}\text { A kivezetés hatása a fenntartási } \\
\text { költségekre }\end{array}$ & $\begin{array}{l}\text { a rendszer fenntartási költségek } \\
\text { csökkenhetnek }\end{array}$ & a fenntartási költségek csökkenhetnek \\
\hline Tréning & \multicolumn{2}{|c|}{ szükséges } \\
\hline A kivezetés eredménye & normál vagy kényszermigráció & helyettesítő termék \\
\hline $\begin{array}{l}\text { A kivezetésből származó } \\
\text { előnyök }\end{array}$ & \multicolumn{2}{|c|}{$\begin{array}{l}\text { - } \quad \text { a menedzsment és sales erőfeszítések egyszerüsítése/koncentrációja; } \\
\text { - } \quad \text { termék/szolgáltatás portfólió teljesítményének továbbfejlesztése; } \\
\text { - } \quad \text { ügyfélmenedzsmenttel kapcsolatos elönyök; } \\
\text { - fizikai és pénzügyi eröforrás menedzsment javítása. }\end{array}$} \\
\hline
\end{tabular}

\section{Forrás: saját szerkesztés}




\subsubsection{SZOLGÁLTATÁSKIVEZETÉS SZAKIRODALOM}

A szolgáltatáskivezetést kizárólag egy szük kutatói csoport vizsgálta (Argouslidis \& McLean, 2003; Kent \& Argouslidis, 2005; Gounaris et al., 2006; Argouslidis \& Baltas, 2007; Argouslidis, 2007a), és annak ellenére, hogy az első tanulmányok a témában 2001-ben jelentek meg (Argouslidis, 2001; Argouslidis \& McLean, 2001a), a téma még mindig meglehetősen alulkutatott. Bár a téma fontossága a szakirodalomban egyértelmű (Argouslidis, 2001; Avlonitis \& Argouslidis, 2012), a szolgáltatáskivezetésnek számos feltáratlan területe van, mint például a szolgáltatáskivezetés utáni szakasz vagy az ügyfél szemszögü tanulmányok. Ahhoz, hogy ezt a rést csökkentsük, empirikus eredményekkel szeretnénk támogatni a szolgáltatáskivezetés ügyfél reakcióinak területét, elsődlegesen a szolgáltatáskivezetés utáni szakaszra fókuszálva.

A szakirodalomban a termék -és szolgáltatáskivezetés tanulmányozása gyakran együtt történik, habár a két koncepció között vannak különbségek, amelyeket már bemutattunk. Avlonitis és Argouslidis (2012) egy áttekintést adnak a területről, amelyet a szolgáltatáskivezetésre szükítettünk le, a szolgáltatás- és termékkivezetés közti különbségek miatt. A szolgáltatáskivezetési folyamatnak három szakasza van: 1. a szolgáltatáskivezetés előtti szakasz, amely meghatározza a célokat; 2. a szolgáltatáskivezetési döntési folyamat, amely meghatározza a szolgáltatáskivezetési folyamat jellemzőit; 3. a szolgáltatáskivezetés utáni szakasz, amely a szolgáltatáskivezetés eredményére fókuszál. A szolgáltatáskivezetés szakirodalom áttekintésével látható, hogy a témát leggyakrabban a pénzügyi szektorban, vállalati szemszögből vizsgálják (Argouslidis, 2001; Argouslidis \& McLean, 2003; Argouslidis, 2007; Argouslidis \& Baltas, 2007).

A teljesítmény eredményét kizárólag termelési szektorokban vizsgálják, a sikertényezőket pedig a pénzügyi és több szektort érintő tanulmányokban, vállalati oldalról. Meglepő módon nincsen olyan ügyfél szemszögü elemzés a szolgáltatási területen, amelyet a kivezetés utáni szakasszal kombináltak volna, különösképpen nem a sikertényezőkkel, amely így egy jelentős rés a szakirodalomban (4. táblázat). Kizárólag a termékkivezetés területén találtunk két tanulmányt, amely az ügyfelet helyezi a vizsgálat középpontjába (Avlonitis, 1983; Homburg et al., 2010). Harness (2004) az ügyfél perspektívával kapcsolatos hiányzó empirikus eredményekre hívja fel a figyelmet, mivel a kivezetés hatását elsősorban a vállalat szemszögéből vizsgálják. Ezért fókuszálunk erre a területre kutatásunkban.

A szolgáltatáskivezetés utáni szakaszon belül vállalati nézőpontból a stratégiai döntés szerepe és a vállalat típusa kiemelten meghatározzák a szolgáltatáskivezetés sikerességét 
(Harness \& Marr, 2004; Gounaris et al., 2006). Ez részben indokolja választásunkat a telekommunikációs szektorra vonatkozóan, mivel a vállalat típusa lényeges eltéréseket okozhat a szolgáltatáskivezetésben, amelyek nem tárhatóak fel kizárólag pénzügyi szektorra vagy néhány több szektorra fókuszáló tanulmánnyal.

Tehát a szolgáltatáskivezetés szakirodalmi áttekintése megalapozta fő témánkat és kutatásunk kontextusát egyaránt: a szolgáltatáskivezetés sikertényezőinek azonosítása az ügyfél szemszögéből a telekommunikációs szektorban.

\section{4. táblázat: A szolgáltatáskivezetés szakirodalom összegzése}

\begin{tabular}{|c|c|c|}
\hline \multirow{2}{*}{ TÉMÁK } & \multicolumn{2}{|c|}{ VÁLLALATI PERSPEKTÍVA } \\
\hline & PÉNZÜGYI SZOLGÁLTATÁSOK & EGYÉB VAGY TÖBB SZEKTOR \\
\hline A szolgáltatáskivezetési gyakorlat általános jellemzése & (Argouslidis \& McLean, 2001a) & \\
\hline \multicolumn{3}{|l|}{ 1. A szolgáltatáskivezetés előtti szakasz } \\
\hline Elérendő célok & $\begin{array}{c}\text { (Argouslidis \& McLean, 2001b) } \\
\text { (Argouslidis, 2006) }\end{array}$ & \\
\hline Korlátozó körülmények & $\begin{array}{l}\text { (Harness et al.,, 1998) } \\
\text { (Argouslidis, 2007b) }\end{array}$ & \\
\hline \multicolumn{3}{|l|}{ 2. A szolgáltatáskivezetés döntéshozatali folyamata } \\
\hline A kivezetendő szolgáltatások azonosítása & $\begin{array}{l}\text { (Argouslidis \& McLean, 2003) } \\
\text { (Argouslidis \& McLean, 2004) }\end{array}$ & \\
\hline Elemzés és módosítás & (Argouslidis \& McLean, 2004) & \\
\hline Értékelés és döntéshozatal & $\begin{array}{c}\text { (Harness., 2004) } \\
\text { (Argouslidis, 2007a) }\end{array}$ & \\
\hline Implementáció & $\begin{array}{l}\text { (Harness \& Marr, 2001) } \\
\text { (Argouslidis, 2004) }\end{array}$ & \\
\hline \multicolumn{3}{|l|}{ 3. A szolgáltatáskivezetés utáni szakasz } \\
\hline \multicolumn{3}{|l|}{ Teljesítmény eredménye } \\
\hline Sikertényezők & (Harness \& Marr, 2004) & (Gounaris et al., 2006) \\
\hline \multicolumn{3}{|l|}{ 4. Szervezeti és strukturális kérdések } \\
\hline \multicolumn{3}{|l|}{ Részvétel } \\
\hline Döntéshozatali struktúra (pl. formalizáció) & (Argouslidis \& Baltas, 2007) & \\
\hline A döntés gyorsasága & (Argouslidis, 2008) & \\
\hline $\begin{array}{l}\text { 5. A szolgáltatáskivezetés történelmi, szabályozási és gazdasági } \\
\text { vonatkozásai }\end{array}$ & & (Chisholm \& Norman, 2006) \\
\hline
\end{tabular}

\section{Forrás: Avlonitis és Argouslidis (2012) alapján saját szerkesztés}

A szakirodalmi áttekintés módszertani szempontból arra világított rá, hogy a tanulmányok elsősorban kevert, kvalitatív-kvantitatív módszertanra épülnek. Argouslidis és McLean (2003) is egy kombinált kvalitatív és kvantitatív kutatási módszertant használtak: mélyinterjút és kérdőíves megkérdezést. A cikk empirikus eredményeket mutat be a) a brit pénzügyi intézmények deviáns teljesítményére és pénzügyi szolgáltatásaira vonatkozóan, amelyek közül kerülnek ki a kivezetett szolgáltatások, és b) azok a tevékenységek, amelyek 
helyreállíthatják a deviáns teljesítményt, amennyiben ez lehetséges és megvalósítható. A pénzügyi szektort érintő későbbi tanulmányai (Kent \& Argouslidis, 2005; Argouslidis, 2007) hasonló módszertant használtak, a formalizáció termékkivonásra gyakorolt hatását a pénzügyi intézetek kivezetési döntéseiben, és a szolgáltatáskivezetési döntéshozatal és szervezeti döntéshozatal strukturális jellemzői közti kapcsolat fenntartásában való vizsgálata során. A szolgáltatáskivezetési döntés és implementáció szintén kulcsfontosságú Gounaris, Avlonitis, és Papastathopoulou munkájában (Gounaris et al., 2006).

Habár a szolgáltatáskivezetés sikertényezői jelentős rést képez a szolgáltatáskivezetési szakirodalomban, a téma relevanciáját a szerződéses viszony jelentősen befolyásolja. Ha az ügyfél nem áll szerződéses kapcsolatban a szolgáltató vállalattal, akkor a meglévő szolgáltatás kivezetését követően az ügyfelek egyszerủen átirányíthatóak más szolgáltatás csomagokra. A szerződéses típusú szolgáltatáskutatás szakirodalom viszont azt mutatja, hogy a szerződés önmagában megváltoztatja az egész kapcsolatot, az ügyfélreakciókat kiemelten. Kutatásunkban ezért vizsgáljuk a szolgáltatáskivezetés utáni szakaszt, szerződéses kapcsolat esetében.

Lovelock (1983) definiálta a szolgáltató vállalat és ügyfél közötti kapcsolat főbb típusait. Az úgynevezett „tagsági” (membership) kapcsolat a szerződéses típusú szolgáltatásokra vonatkozik, és az informális kapcsolatok pedig azok, ahol nincsen szerződéses kapcsolat a két fél között.

A szolgáltatáskivezetés kiemelten a tagsági viszony esetében releváns, hiszen ettől eltérő esetben a feleknek nincsenek jogi kötelezettségei, vagyis a szolgáltató vállalat sem köteles új szolgáltatást ajánlani az ügyfélnek a kivezetést követően, és az ügyfél is elhagyhatja a vállalatot kötbér fizetése nélkül. Összességében tehát a szerződés nélküli kapcsolat olyan mértékben eltér a szerződésestől, hogy teljesen más stratégiák vonatkoznak a két esetre. Kutatásunkban a szolgáltatáskivezetést kizárólag szerződéses kapcsolat esetén vizsgáljuk.

A szolgáltatáskivezetési szakirodalom áttekintésének fontos tanulsága tehát, hogy a szolgáltatáskivezetés előtti szakasz és a szolgáltatáskivezetési folyamat tulajdonképpen jól feltárt területek, a szolgáltatáskivezetés utáni szakasz és az ügyfél oldal azonban meglehetősen elhanyagolt területnek számítanak. Kutatásunkat ezekre a területekre irányítjuk, mert a szolgáltatáskivezetés eredménye befolyásolja az ügyfeleket, ezáltal hatással van az ügyfélmegtartásra, elégedettségre és lojalitásra, amely hozzájárulhat a terület eredményeinek gazdagításához. 
Az ügyféloldal megértése tehát hozzájárulhat a szolgáltatáskivezetés és ügyfélmegtartás szakirodalomhoz egyaránt, ezáltal felgyorsítva a szolgáltatásportfóliók innovációját és csökkentve az ilyen esetekben jelentkező ügyfél lemorzsolódást.

Az IT fejlesztések által felgyorsított technológiai változások hatására a szolgáltatáskivezetés a szolgáltatásfejlesztések előkövetelményének tekinthető, és annak ellenére, hogy a szakirodalomban ez egy elhanyagolt területnek számít, fontossága fokozatosan növekszik.

A következő részben azonosítjuk a szolgáltatáskivezetés fö tényezőit a következő három szakasz alapján: szolgáltatáskivezetés előtti szakasz, implementáció, és szolgáltatáskivezetés utáni szakasz. Ezzel a besorolással az ügyféloldali perspektívát követjük, hiszen fö célunk a szolgáltatáskivezetés ügyfelekre gyakorolt hatásának vizsgálata. Egyes tanulmányok (pl. Argouslidis, 2001) vállalati oldalról elemzik a szolgáltatáskivezetés előtti szakaszt, a szolgáltatáskivezetés döntési folyamatát és a szolgáltatáskivezetés utáni szakaszt, de az ügyfél fókusz miatt az implementációs folyamatra és a szolgáltatáskivezetés eredményére összpontosítunk, a szolgáltatáskivezetési döntési folyamat szervezeten belüli vizsgálata helyett. Vagyis a szolgáltatáskivezetés szakaszain belül Argouslidis (2001) besorolását követjük azzal a változtatással, hogy a szolgáltatáskivezetés sikerességének meghatározása miatt az implementációra nagyobb hangsúlyt helyezünk: a döntési folyamatot a szolgáltatáskivezetés elötti szakasz részének tekintjük, amelyet az implementáció és a szolgáltatáskivezetés utáni szakasz követnek.

\subsubsection{SZOLGÁLTATÁSKIVEZETÉS ELÖTTI SZAKASZ}

A szolgáltatáskivezetés előtti szakasz az okokat, a döntési folyamatot, a mozgatórugókat és korlátokat foglalja magában, míg az implementáció a szolgáltatáskivezetés végrehajtását jelenti és a szolgáltatáskivezetés utáni szakasz a szolgáltatáskivezetés vállalatra és ügyfelekre gyakorolt hatásából áll.

\subsubsection{OKOK ÉS CÉLOK}

Argouslidis (2001) szerint a szolgáltatáskivezetés fö céljai a következőek ${ }^{1}$ (Argouslidis, 2001)): a pénzügyi mutatók javítása, a vállalati erőforrások koncentrációja, az ügyfelek bizonytalanságának csökkentése és a termék/szolgáltatás kannibalizáció kontrollálása a szolgáltatásportfólió racionalizálása által. Emellett a szerző olyan problémás helyzeteket is

\footnotetext{
${ }^{1}$ Ebben a fejezetben a pénzügyi szektor kutatása során kapott eredményeket sok helyen használjuk a telekommunikációra vonatkozóan, mivel a szolgáltatáskivezetésröl telekommunikációs kontextusban nincsenek hasonló eredmények és bizonyos szempontból hasonlónak tekinthető a két szolgáltatás, tagsági jellegük miatt.
} 
azonosít, mint a kereslet csökkenése, visszautasítás, csökkenő profitabilitás, jogi változások és új szabályozások, a meglévő vállalati stratégiával való inkompatibilitás, megváltozott üzleti pozícionálás, a szolgáltatás élesbe állításának technikai problémái, vagy a meghatározó folyamatokban kulcsfontosságú szerepet betöltő ember távozása a vállalattól. Habár a szolgáltatáskivezetésnek világosan definiált céljai vannak, a vállalatok rendszerint az életciklus végén alkalmazzák a szolgáltatáskivezetést (Kurtz \& Clow, 1998; Palmer, 1998; Kasper et al., 2008).

Fontos megjegyezni azonban, hogy annak ellenére, hogy a csökkenő profitabilitás a kivezetés fontos mozgatórugója, nem feltétlenül kapcsolható össze a szolgáltatás életciklusának végével: a szolgáltatásinnováció (2.2.2. fejezet) a kivezetés másik gyakori kiváltó oka.

\subsubsection{A SZOLGÁLTATÁSKIVEZETÉS DÖNTÉSI FOLYAMATA}

Argouslidis (2001) a szolgáltatáskivezetési döntési folyamat fázisait a következőképpen definiálja: a kivezetendő szolgáltatások azonosítása, elemzés és revitalizálás, értékelés, döntéshozatal, és implementáció. Emellett olyan audit kritériumok is meghatározzák a kivezetendő szolgáltatások körét, mint például a profitabilitás, értékesítési mennyiség piacnövekedési potenciál, az ügyfelek percepciója, a versenytársak tevékenysége, piaci részesedés, a szolgáltatás életciklusa, operatív jellegü problémák (pl. design, és a szolgáltatás előállítása), azzal a kiegészítéssel, hogy a vállalatnak a szolgáltatáskivezetés ügyfelekre, vállalati imázsra, más szolgáltatásokra, teljes termékkínálati irányelvekre, a szervezetre, a piacon elérhető hasonló termékekre gyakorolt hatását, és a versenyelőny esetleges elvesztésének lehetőségét is kezelnie kell.

Argouslidis (2001) szerint a kivezetésben legfontosabb résztvevők (sorrendben): marketing, pénzügy, a kivezetendő szolgáltatás menedzsere, sales, menedzsment bizottság, ügyvezető igazgató, ügyfélszolgálati személyzet, CEO/elnök, igazgatóság, vezérigazgató, és az adminisztratív személyzet. A döntéshozatali folyamat átlagos ideje 5,6 hónap (a nyesett átlag 4,7 hónap).

A formalizáció kiemelt jelentőségű a döntési folyamatban (Argouslidis \& Baltas, 2007).

\subsubsection{A SZOLGÁLTATÁSKIVEZETÉS MOZGATÓRUGÓI}

A mozgatórugók az értékelési folyamattal ellentétben sokkal inkább a menedzsment döntésére hatnak, mert a kivezetés termékhelyettesítéssel jár (Avlonitis \& James, 1982). Ez napjainkban is egyre fontosabbá válik, mivel az új portfóliók iránti igény fokozatosan nö, és ez 
egyértelműen hozzájárul a jelenlegi szolgáltatások kivezetéséhez. Ennek ellenére meglehetősen gyakori a kivezetés nélküli szolgáltatásfejlesztés (Somosi \& Kolos, 2014).

Argouslidis (2001) a mozgatórugók közül pénzügyi szolgáltatások esetében megkülönbözteti a külső, stratégiai, operacionalizált, sales és ügyfél által irányított típusokat.

\subsubsection{A SZOLGÁLTATÁSKIVEZETÉS KORLÁTAI}

A szolgáltatáskivezetés korlátja nem más, mint „, a szervezetre kívülröl háruló dolog, jogi szabályozás vagy szerződéses megállapodás” (Harness, 2004, 171. o.). Ezeknek a korlátoknak elsősorban az a szerepük, hogy megakadályozzák az ügyfél jóváhagyása nélkül történő terméket vagy szolgáltatást érintő módosításokat. A kivezetés kivitelezése, többek között az, hogy a teljes kivezetés lehetséges-e, elsősorban a külső korlátoktól függ, például jogi szabályozásoktól, szerződéses kötelezettségektől és belső korlátoktól, amelyeket a szervezet azért hoz létre, hogy a kivezetés után is fenn tudja tartani az ügyfeleivel a kapcsolatot. Vagyis ezek a korlátok sokszor a teljes kivezetés megakadályozása érdekében léteznek.

A kivezetés három típusa a következő: nincsenek korlátok, ügyfelek által létrehozott korlátok (ezeket vagy egy külső tényező kényszere miatti kivezetés vagy magas fenntartási költségek miatt hoznak létre), a szervezet által létrehozott ügyfélorientált korlátok, vagy külső korlátok a teljes kivezetés megakadályozására (részleges kivezetési stratégia) (Harness, 2004). A vállalatok rendszerint azért állítanak korlátokat, hogy minimalizálják a teljes kivezetés esetén alkalmazott kényszermigráció esetén fellépő lemorzsolódást.

\subsubsection{A SZOLGÁLTATÁSKIVEZETÉS IMPLEMENTÁCIÓJA}

Ahogyan már a szolgáltatáskivezetés definíciójánál kitértünk rá, az általunk kutatott teljes kivezetésen kívül a kivezetésnek számos formája létezik, mint például a részleges kivezetés, szolgáltatás lezárás, egyes szegmensektől való lezárás, szolgáltatás összeolvasztás, szolgáltatás- egyszerüsítés, stb. Ezek az alternatív szolgáltatáskivezetési stratégiák tükrözik az egyes definíciók közti eltéréseket.

A szolgáltatáskivezetés implementációját jelentősen meghatározza a szolgáltatóvállalat és az ügyfél közti általános interakció és a kommunikáció minősége. A szakirodalomban ez az interakciós intenzitáshoz kapcsolódik, amely bizonyítottan hatással van a minőségre és az elégedettségre (Bateson, 1985; Mills \& Morris, 1986; Hill, 1988; Kelley et al., 1990; Cermak et al., 1991). Ez a szolgáltatáskivezetés esetében azt jelenti, hogy a szolgáltatóvállalat és az 
ügyfél közti közvetlen interakció növelheti a szolgáltatásminőséggel kapcsolatos ügyfélpercepciókat, amely ügyfélmegtartást eredményezhet.

Ilyen értelemben az ügyféllel való együtt-teremtés (co-creation) (Prahalad \& Ramaswamy, 2004) hozzájárulhat a szolgáltatáskivezetés sikerességéhez a jelenlegi szolgáltatás kivonását követően, az új szolgáltatás ügyfél igényeihez való adaptálása által.

Ezeken kívül a szolgáltatáskivezetés implementációja egy stratégiai döntés eredménye kell, hogy legyen, mert a felsővezetés attitüdje és a formalizáció általában meghatározzák a szolgáltatáskivezetés minőségét (Argouslidis \& Baltas, 2007).

A szolgáltatáskivezetési folyamat során az ügyfelek pénzügyi és nem pénzügyi költségekkel egyaránt szembesülnek, amelyek elsősorban a meglévő szolgáltatás alternatívájának kereséséhez kötődnek. A keresési költségeken (a piacon és a jelenlegi szolgáltatónál elérhető alternatívák összehasonlítása) kívül, számos nem pénzügyi jellegü költség is felmerül, mint például az idő, fizikai erőfeszítés, pszichológiai teher (szellemi erőfeszítés, észlelt kockázat és szorongás, kognitív disszonancia, félelemérzet, stb.), és érzékelési teher (tömeg, zaj, kellemetlen illatok, szélsőséges időjárási feltételek, kényelmetlen és/vagy nem vonzó várakozási helyiségek, stb.) (Wirtz \& Lovelock, 2016). Ezek kapcsolódnak a társadalmi csere elmélethez is (Homans, 1958).

\subsubsection{SZOLGÁLTATÁSKIVEZETÉS UTÁNI SZAKASZ}

A szakirodalmi áttekintésünk tehát a szolgáltatáskivezetés utáni szakaszt egy lényeges résként azonosította: „A szolgáltatáskivezetés utáni szakasz szinte teljesen elhanyagolt a kivezetési szakirodalomban” (Argouslidis, 2001, 421. o.).

Argouslidis (2001) a szolgáltatáskivezetés utáni szakaszra hívja fel a figyelmet, mivel (1) egy integrált áttekintés a folyamatról a jövőben használható fontos referencia lenne, (2) a meglévő és potenciális új ügyfelek is érintettek lehetnek a folyamatban, (3) vannak olyan esetek, amikor a szolgáltatás teljesen nem szünik meg (pl. részleges kivezetés, pseudokivezetési implementációs stratégia, egyszerüsítés, szolgáltatás összeolvasztás, szolgáltatás lezárás). Emellett a szerző hozzáteszi, hogy a folyamat során a vállalatnak a meglévő ügyfelekkel kedvezőbben kellene eljárnia, mint az új ügyfelekkel, etikus magatartást mutatva feléjük.

A szolgáltatáskivezetés utáni szakasszal kapcsolatban azonban mégis az a legfontosabb kérdés, hogy a kivezetés maga sikeresnek tekinthető-e. Meglepö módon kizárólag két tanulmány foglalkozik ezzel a kérdéssel szolgáltatások esetében vállalati oldalról (Harness \& Marr, 2004; Gounaris et al., 2006), amelyek azt emelik ki, hogy a siker elsősorban a 
szolgáltatáskivezetés stratégiai döntésként való kezelésével és több részlegen átívelő csapatok összeállításával érhető el, ahol a döntés egy szisztematikus viselkedés eredménye.

A szolgáltatáskivezetés sikeressége azonban nagyban függ a szolgáltatáskivezetés definiálásától is, hiszen a részleges kivezetés esetében például már az is sikernek tekinthető, ha az ügyfelek a meglévő szolgáltatást továbbra is használják (Harness, 2004). Tanulmányunkban azonban kizárólag a teljes kivezetést tekintjük szolgáltatáskivezetésnek.

Számos módszer létezik a szolgáltatáskivezetés eredményének vizsgálatára (Argouslidis, 2001), mint például az ügyfélmegtartási ráta, profitabilitás és az új szolgáltatás értékesítése, ügyfélpanaszok szintje, amelyek közül tanulmányunkban az ügyfélmegtartási ráta megközelítését követjük.

\subsubsection{A SZOLGÁLTATÁSKIVEZETÉS ÜGYFELEKRE GYAKOROLT HATÁSA}

Az ügyfélreakciók számos olyan koncepciót érintenek, amelyek hatással vannak a szolgáltatáskivezetés eredményére, és ezért kutatásunk szempontjából relevánsak. Ilyen fogalom többek között az elégedettség, lojalitás, elkötelezettség, szájreklám (WOM) és a panaszkodás, amelyek kutatásunk szempontjából megítélt fontossága ügyfélmegtartásra gyakorolt hatásukban jelenik meg. A következőkben elsőként a lemorzsolódást (churn), az ügyfélmegtartás mérőszámát tekintjük át. Ezt követi az elégedettség, lojalitás, elkötelezettség és WOM, azok ügyfélmegtartásra való hatásának jellemzésével.

A szolgáltatáskivezetési folyamat jobb megértéséhez a szolgáltatások igénybevételének háromlépcsős modelljét használjuk (three-stage model of service consumption) (Wirtz \& Lovelock, 2016). A vásárlás előtti szakasz nem releváns a szolgáltatáskivezetés szempontjából, hiszen egy szolgáltatás kivezetésre kerül, nem megvásárlásra. A második lépés a szolgáltatás igénybevételének szakasza, amely esetünkben maga a szolgáltatáskivezetés, ahol azok az általános kifejezések, mint az igazság pillanatai (moments of truth) vagy a servuction rendszer tekinthetőek azoknak az elemeknek, amelyek a szolgáltatáskivezetési folyamathoz kapcsolódó ügyfélélményt fejezik ki és egyúttal meghatározzák az ügyfél a szolgáltatóról alkotott véleményét. A kellemetlen élmény érinti az ügyfélmegtartást, néha sokkal hatékonyabb, mint az új ajánlat tartalma. A harmadik lépés a szolgáltatás igénybevétele utáni szakasz, amely minden ügyfélreakcióhoz kötődő fogalmat megába foglal (az előzetes várakozások elfogadása/megcáfolása, elégedetlenség, elégedettség és öröm, szolgáltatásminőség, szájreklám, újravásárlás és lojalitás) szolgáltatáskivezetés esetén, amely kutatásunk központi témája. 
Meg kell jegyeznünk azonban, hogy az ügyfelek különbözőek, és a Servicescape modell szerint (Bitner M. J., 2000) léteznek ún. ügyfél és alkalmazotti válasz moderátorok, amelyek befolyásolhatják az egyes vevők ugyanazzal a szolgáltatással kapcsolatos tapasztalatait, a saját preferenciáik különbözősége miatt.

Az ügyfélmegtartás definíció szerint az ügyfél ,életben maradási valószínüsége, vagy egy vállalattól való ismételt vásárlás” (Gupta et al., 2006, 144. o.). Az ismételt vásárlás egyúttal azt is jelenti, hogy az ügyfelek lojálisak a vállalathoz, amely ügyfélmegtartáshoz vezet. A szerződéses és nem szerződéses viszony között azonban lényeges eltérések tapasztalhatóak: az előző esetében az ügyfelek értesítik a vállalatot egy esetleges távozási szándékról, az utóbbi esetben azonban a vállalatnak szükséges információt szereznie az ügyfelek tevékenységéről.

A lemorzsolódás (churn) az ügyfélmegtartás operatív mérőszáma (Gustafsson et al., 2005). A telekommunikációs szektorban az ügyfél lemorzsolódást (customer churn) használják az ügyfél egyik szolgáltatótól másik felé történő mozgásának jelzésére, és a lemorzsolódás menedzsment (churn management) a szolgáltató profitábilis ügyfelek megtartására irányuló folyamatát fejezi ki (Berson et al., 2000).

A pénzügyi szektorban a szolgáltatáskivezetés eredményét számos módon ítélhetik meg (Argouslidis, 2001, 238. o.): a helyettesítő szolgáltatás eladási mennyisége; a helyettesítő szolgáltatás profitabilitása; az operacionalizálási problémák megoldása; a keresztértékesítésre gyakorolt hatás; az ügyfélpanaszok aktuális szintje; ügyfélmegtartási ráták; az ügyfelek vállalati megítélése; a vállalattal való nagyobb mértékü ügyfél elköteleződés valószínűsége; új ügyfélszerzési ráták. Argouslidis (2001) ezenkívül azt is hozzáteszi, hogy a pénzügyi intézmények nem végeznek szolgáltatáskivezetést követő elemzéseket a kivezetési döntés helyességének megítélésére.

Mivel kutatásunkban a szolgáltatáskivezetést követő ügyfélreakciókat helyezzük előtérbe, a szolgáltatáskivezetés eredményének megítélésére az ügyfélmegtartást használjuk, amely segít a lemorzsolódás okainak feltárásában szolgáltatáskivezetés esetén. A lemorzsolódással kapcsolatos tanulmányok vonatkozhatnak a lemorzsolódás okára, megtartásra vagy a lemorzsolódás típusára (Braun \& Schweidel, 2011). Kutatásunk a megtartásra fókuszál.

A telekommunikációs szakirodalomban számos lemorzsolódást előrejelző modell található, amelyek az adatbányász módszereket emelik ki elsősorban (pl. döntési fák, neurális hálók, K-középpontú klaszter, stb.) (Hung et al., 2006). Risselda és szerzőtársai (2010) a 
lemorzsolódást előrejelző modellek evolúcióját vizsgálta, amely azért fontos számunkra, mert a szolgáltatáskivezetés sikerességét meghatározó egyik kiemelt méröszám (key performance indicator, KPI) a csökkentett lemorzsolódási ráta. Ez az egyik oka, hogy a lemorzsolódást a szolgáltatáskivezetéssel kombináljuk, amely azonban nem gyakran alkalmazott eszköz a szolgáltatáskivezetés ügyfelekre gyakorolt hatásának becslésére (a kérdésre vonatkozóan nem találtunk empirikus tanulmányt). Azért esett választásunk a lemorzsolódásra, mert a szolgáltatóiparban gyakran használják egy szolgáltatás ügyfél-elégedettségének a meghatározására. A szolgáltatáskivezetés nagyon speciális ebben az esetben: a kivezetési folyamat sokszor kényszermigrációval jár, amely megváltoztatja az ügyfelek magatartását és ilyen esetekben a legmagasabb a lemorzsolódási ráta. Vagyis a lemorzsolódás kulcsfontosságú telekommunikációs kontextusban.

Neslin és szerzőtársai (2006) a módszertan fontosságára hívják fel a figyelmet, hiszen az alkalmazott módszertan sokfélesége jelentős eltéréseket okozhat a lemorzsolódási stratégiák profitabilitásának becslésében és a teljesítményben.

Az általunk alkalmazott lemorzsolódás modellezési eljárás az analitikus CRM (customer relationship management) módszerekhez sorolható, amely az ügyfél interakciókkal kapcsolatos vállalati információ gyüjtése és elemzése az ügyfélérték növelése érdekében (Kamakura et al., 2005). A CRM stratégia emellett az ügyfél életciklusát is követheti, az ügyfélszerzési, fejlesztési és megtartási stratégiát is beleértve. A megfelelően megtervezett és kivitelezett szolgáltatáskivezetés tehát a megtartási stratégia része lehet a CRM-en belül.

Knox és Oest (2014) a lemorzsolódás valószínűségét a korábbi panaszok hatásával, a korábbi vásárlásokkal és panaszkezeléssel mérik. Kimutatták, hogy a korábbi panaszok száma növeli a lemorzsolódás valószínűségét, míg a panaszkezelés csökkenti azt. Meglepő módon azonban a vásárlás lemorzsolódás csökkentő hatása sokkal hosszabb (315 nap), mint a panaszoké (8 nap) (Knox \& Oest, 2014, 48. o.). Ez azt jelenti, hogy ha az ügyfél az első panaszt követően nem hagyja el a vállalatot, akkor már inkább valószínű, hogy a vállalatnál marad.

Vagyis a lemorzsolódás szakirodalom alapján a szolgáltatáskivezetés az elégedettség és elkötelezettség egy szituációs tényezőjeként tekinthető, amely befolyásolja az ügyfélmegtartási stratégiát. Vagyis a normál ügyfél lemorzsolódási rátát meghatározó modelleket (Rust et al., 1995; Ho \& Zheng, 2003; Kamakura et al., 2005; Prince \& Greenstein, 2011; Kumar \& Petersen, 2012) a szolgáltatáskivezetés hatásának becslése érdekében módosítani kell. A szolgáltatáskivezetés és lemorzsolódás szakirodalom ezekkel az 
eredményekkel való kiegészítése segít feltárni a szolgáltatáskivezetés esetén jelentkező lemorzsolódás sajátosságait.

Az ügyfélreakciók között számos kapcsolódó fogalmat mutatunk be, mint például az elégedettség, lojalitás, elkötelezettség és WOM, azok ügyfélmegtartásra gyakorolt hatásuk miatt. A szolgáltatáskivezetés utáni szakasz fejlesztéséhez szükséges ezeknek a releváns koncepcióknak a megértése és alkalmazása. A következőkben a köztük lévő főbb eltéréseket tekintjük át.

Az ügyfélelégedettség egy ajánlat teljesítményének vizsgált időpontig terjedő átfogó ügyfélértékelése (Johnson \& Fornell, 1991). Általánosságban az ügyfélreakcióhoz kötődő elégedettségi állapotot fejez ki, illetve az ügyfél megítélését az elégedettségi állapotról (Oliver, 1997). Az ügyfélelégedettséget meghatározó fö tényező az észlelt szolgáltatásminőség (Zeithaml, 1996). A szolgáltatásminőséget a telekommunikációs szektorban a hívás minőségével, árazási szerkezettel, mobilkészülékekkel, értéknövelt szolgáltatásokkal (valueadded services), a folyamatok kényelmi szintjével és az ügyfél számára nyújtott támogatással mérik (Kim, 2000; Gerpott et al., 2001; Lee et al., 2001). Kim és szerzőtársai (2004) szerint a telekommunikációs ügyfélelégedettséget elsősorban a hívás minősége, a kiegészítő szolgáltatások (pl. mobilinternet, multimédiás szolgáltatások, lokáció-alapú szolgáltatások) és az ügyfélszolgálat határozzák meg.

Az ügyfél és a szolgáltatóvállalat közti diadikus kapcsolat volt a tárgya a kezdeti kutatásoknak: Surprenant és Solomon (1987) a szolgáltatás igénybevételét definiálták az elégedettség fő mozgatórugójaként. A teljesítményekkel kapcsolatos elvárások teljesítmény megerősítést vagy cáfolatot váltanak ki, amely az elégedettség eredményét képezi (Oliver, 1997). A szolgáltatás sikerességét tekintve az elégedettség ismételt vásárlásra gyakorolt hatása kritikus, amelyet nemcsak kizárólag a szolgáltatással való általános elégedettség, hanem a vállalatról alkotott szolgáltatásminőséggel kapcsolatos percepció is meghatároz. Így az ügyfelek megpróbálják előrejelezni a szolgáltatás minőségét a szolgáltató vállalathoz füződő korábbi tapasztalatok alapján. Ha általánosságban elégedettek a szolgáltatással, akkor egy rossz tapasztalat még nem befolyásolja azt, hogy visszatérnek-e az adott vállalathoz, viszont ha az elégedetlenség szintje a további látogatások alkalmával folyamatosan nő, akkor az már csökkenti az ismételt vásárlás valószínüségét (Wirtz \& Lovelock, 2016). Vagyis az elégedettség összességében erősen befolyásolja a lojalitást széles termék és szolgáltatás kategóriákban, a telekommunikációs szolgáltatásokat is beleértve (Fornell, 1992; Fornell et al., 1996). 
Az ügyfélelégedettség számos kutatás témája a magyar szakirodalomban egyaránt, amelyek a fogalmak elméleti megközelítése mellett (Hofmeister et al., 2003), elsősorban az elégedettség és a lojalitás közti kapcsolatot (Hetesi \& Veres, 2005; Bátor, 2007), és azok szolgáltatásminőséggel való összefüggésrendszerét vizsgálják (Rekettye et al., 2002; Hetesi, 2003). Ezeken kívül többek között az ügyfélmenedzsment elemzése is megjelenik (Piskóti, 2008).

Az elkötelezettség azt fejezi ki, hogy a cserében részt vevő partner milyen mértékben szándékozik folytatni a kapcsolatot (Moorman et al., 1992). Az affektív és kalkulatív elkötelezettség közti különbség abban ragadható meg, hogy mindkét fogalom a lojalitás mozgatórugója, de másképp: az affektív elkötelezettség (affective commitment) személyes interakció, reciprocitás és bizalom eredménye; míg a kalkulatív elkötelezettség (calculative commitment) a váltási költségeken keresztül jön létre (Morgan \& Hunt, 1994; Bendapudi \& Berry, 1997; Garbarino \& Johnson, 1999; Fullerton, 2003). Az elkötelezettség és elégedettség között az a különbség, hogy az affektív elkötelezettség jövőbe tekintő, míg az elégedettség egy visszatekintő értékelés (Verhoef, 2003). Kutatásunk szempontjából fontos, hogy az elkötelezettség meghatározza az ügyfélmegtartást.

Allen és Meyer (1990) az elkötelezettség három típusát az affektív és folytatólagos elkötelezettség (continuance/calculative commitment) normatív elkötelezettséggel (normative commitment) való kiegészítésével definiálják vállalati környezetben: a normatív komponens a kötelezettséggel kapcsolatos érzelmeket, az affektív komponens az érzelmi kötődést, míg a folytatólagos komponens a kalkulatív elkötelezettséghez hasonlóan a vállalat elhagyásához kötődő költségeket fejezi ki. Az affektív elkötelezettség a csere típusának és a viselkedési elkötelezettségnek függvénye (Cook et al., 2003).

Az elkötelezettség nagyban függ az erőegyensúlytól, hiszen a nagy egyensúlytalanság alacsony szintű elkötelezettséghez vezet, míg egy megfelelően kiegyensúlyozott kapcsolat elősegíti az elkötelezettségen alapuló kapcsolatok kialakulását (Molm et al., 2000). Ez a vállalat és az ügyfél szempontjából is releváns szolgáltatáskivezetés esetén, mivel a folyamat során az erőegyensúlyi feltétel nem teljesül, különösképpen kényszermigráció esetén.

Az ügyfélmegtartás, elégedettség és elkötelezettség összefüggéseit tekintve a kutatók arra hívják fel a figyelmet, hogy az elégedettség az ügyfélmegtartás előfeltétele, Kotler úgy fogalmaz, hogy „Az ügyfélmegtartás kulcsa az ügyfélelégedettség” (Kotler, 1994, 20. o.). Gustafsson és szerzőtársai (2005) az ügyfélelégedettséget, affektív és kalkulatív elkötelezettséget azonosítják az ügyfélmegtartás három fő tényezőjeként, és Kotlerhez 
hasonlóan az elégedettséget tartják az ügyfélmegtartás mozgatórugójának. Az elégedettség, affektív és kalkulatív elkötelezettség mérésére skálákat is használtak, azok ügyfél megtartással való kapcsolatának a feltárására.

Hennig-Thurau és Klee (1997) az ügyfélelégedettség és ügyfélmegtartás koncepcionális modelljét is létrehozták: az ügyfélelégedettség hatással van a minőséggel kapcsolatos azonnali percepciókra, amely az ügyfélmegtartás közvetlen előzménye. Továbbá az általános minőséggel kapcsolatos percepciót az elkötelezettség és bizalom előzményeként definiálják, ahol az elkötelezettség a célváltozó.

Rust és Zahorik (1993) az ügyfélmegtartást meghatározó tényezőket kvalitatív és kvantitatív (pl. logisztikus regresszió vagy faktorelemzés) módszerekkel vizsgálták. Fornell és Wernerfelt (1987) matematikai modelljében a piaci részesedést defenzív marketing megközelítésben vizsgálta. Azt az eredményt kapták, hogy az ügyfélmegtartási ráta a piaci részesedés legfontosabb eleme, és az ügyfél- elégedettségtől függ. Ez felhívja a menedzserek figyelmét ezen fogalmak fontosságára, valamint kiemelten az elégedettség és ügyfélmegtartás közötti összefüggésre, hiszen közvetlen kapcsolatban állnak a piaci részesedéssel.

Dick és Basu (1994) a lojalitást „,egy entitás (márka/szolgáltatás/üzlet/kereskedö) iránti relatív attitüd és a vevökör (patronage) viselkedése közti kapcsolat”- ként definiálta (Dick \& Basu, 1994, 100. о.).

Az ügyfél lemorzsolódást elsősorban a lojalitás növelésével lehet csökkenteni, értékelemzés és a lojalitás mozgatórugóinak meghatározásával, illetve a vállalat tagsági viszonyon alapuló kapcsolatokat is megpróbálhat kialakítani, valamint CRM (customer relationship management) rendszereket használni. Szolgáltatáskivezetés esetén gyakran előfordul, hogy a váltási költségek magasak, de általános probléma a lemorzsolódás elemzésének és/vagy hatékony panaszkezelésnek a hiánya.

Az ügyfél lojalitás a viselkedési (sztochasztikus megközelítés), attitüd (determinisztikus megközelítés) vagy az integrált megközelítés alapján definiálható (Oh, 1995). A viselkedési nézet azt fejezi ki, hogy az ügyfél preferenciarendszere kifejeződik az ügyfél viselkedésében (Ehrenberg, 1988), míg az attitüd nézet szerint a lojalitás kizárólag egy attitüdként értelmezhető (Fournier \& Yao, 1997).

A lojalitás kereke (Wirtz \& Lovelock, 2016, 459. o.) három fő pillérből áll: a lojalitás alapjai (a megfelelő ügyfelek megcélzása, a vállalati képességek összehangolása az ügyfelek elvárásaival, az érték keresése a mennyiség helyett, az ügyfélbázis szegmensekre bontása az erőforrások és vállalati kapacitás összpontosítása érdekében, hogy a vállalat a számára értékes 
ügyfelekre tudja fordítani a figyelmét, a szolgáltatásminőségen keresztül viselkedés és attitüd lojalitás kialakítása), a lojalitás kötelékei (a kapcsolat elmélyítése bundling és keresztértékesítés révén, pénzügyi és nem pénzügyi típusú lojalitás kedvezmények felajánlása, mint például szociális, személyre szabott vagy strukturális kötelékek), és az ügyfél lemorzsolódás csökkentése (lemorzsolódás elemzés, a lemorzsolódás fő mozgatórugóinak azonosítása, hatékony panaszkezelés és szolgáltatásjavítás, a váltási költségek növelése, pl. pozitív váltási költségekkel, ún. soft lock-in stratégiákkal, pl. lojalitási kötelékekkel, szerződéses és más hard lock-in stratégiákkal, pl. idő előtti kilépési díjak).

A panaszkezelés gyakran kapcsolódik az ügyfél lojalitáshoz, vagyis a vállalat számára kulcsfontosságú. A panasz nem feltétlenül történik nyilvánosan, de mégis káros a vállalat számára, hiszen elveszítheti ügyfeleit vagy jóhírét. A panasznak számos oka lehet, amelynek feltárása elengedhetetlen a sikeres panaszkezelés érdekében. Érdekes azonban, hogy leginkább a magasabb státuszú emberek tesznek panaszt, mivel valószínüleg több tudásuk van a termékekről (Wirtz \& Lovelock, 2016).

A lojalitás és elégedettség közti kapcsolatot sokszor vizsgálták, és az eltérő vélemények ellenére abban egyetértenek, hogy az ügyfélelégedettség hatással van a lojalitásra (Fornell et al., 1996).

Bolton és szerzőtársai (2000) a lojalitás és ügyfélmegtartás kapcsolatát a pénzügyi szektorban vizsgálták, adatbázis elemzéssel logisztikus és tobit regresszióval, ahol a függő változó a maradási döntés (hasonló az ügyfél megtartáshoz), az elégedettséghez és lojalitáshoz kapcsolódó független változókkal. Eredményeik szerint a lojalitásprogramok közvetlenül nem befolyásolják az ügyfélmegtartást, de más interakciós változókkal már befolyásolják, mint például a vállalat ajánlatai a versenytársakhoz képest. Vagyis a lojalitásprogramok fő hatása abban rejlik, hogy azok az ügyfelek, akik a lojalitásprogramok tagjai, összességében kevésbé érzékenyek a versenytársak által nyújtott árkedvezményekből adódó veszteségekre.

Verhoef (2003) szerint az affektív elkötelezettség és a lojalitásprogramok szignifikáns pozitív kapcsolatban állnak az ügyfélmegtartással, míg az elégedettség pozitív hatását az ügyfélmegtartásra nem tudták empirikusan igazolni. Vagyis az elégedettség és ügyfélmegtartás kapcsolata erősen vitatott a szakirodalomban az eltérő empirikus eredmények miatt. 
Aksoy és szerzőtársai (2013) az elégedettség és lojalitás közti kapcsolatot vizsgálják mobil telekommunikációs ügyfelek esetében, és azt találták, hogy az elégedettség fontos előrejelzője az ajánlásnak/újravásárlásnak.

A magyar szakirodalomban a fő kutatási témák a lojalitással kapcsolatban többek között a lojalitás klaszterei (Hetesi, 2007), a lojalitás mérési kérdései (Hetesi, 2002; Hetesi, 2003; Hetesi \& Rekettye, 2005), a bizalom szerepe (Simay, 2012), de ezek mellett a nemzetközi szakirodalomhoz hasonlóan az elégedettség és lojalitás közötti kapcsolatot is vizsgálják a kutatók (Hetesi \& Veres, 2005; Hetesi, 2003; Bátor, 2008; Simay, 2014).

A szájreklám (WOM) privát felek között, termékek és szolgáltatások értékelésével kapcsolatos informális kommunikáció (Dichter, 1966; Fornell \& Bookstein, 1982; Singh, 1988; Westbrook, 1987). A WOM egyaránt lehet pozitív (pl. kellemes, élénk, új élmények, másoknak való ajánlás), semleges vagy negatív (kellemetlen élmények, pletyka, panasz) (Anderson, 1998).

Anderson (1998) az ügyfélelégedettség lojalitásra és WOM-ra gyakorolt hatását vizsgálta, amelyhez a WOM hasznossági modelljét svéd és USA-ból származó adatokon tesztelték. Az eredmények egy aszimmetrikus $U$ alakú függvényt mutatnak: a szélsőségesen elégedetlen ügyfelek erősebb szájreklámmal élnek a szélsőségesen elégedettekhez képest, de ezek képezik a görbe legmagasabb értékeit. Emellett arra is felfigyeltek, hogy a negatív vállalati kommunikáció nagyobb hatással van a szájreklámra, mint a pozitív. A kutatók azt javasolták, hogy érdemes lenne megvizsgálni a termék- és szolgáltatáskategóriák eltéréseit. Kutatásunk ilyen tekintetben a szolgáltatáskivezetés WOM-ra gyakorolt hatásának elemzéséhez járul hozzá, az ügyfél-elégedettséggel összefüggésben, a telekommunikációs szektorban.

Az affektív elkötelezettség a szájreklámmal kapcsolatos tevékenységgel (lelkesedés és részletesség), és annak dicséret jellegére (pozitív kimenetel) is hatással van. A szolgáltatásminőség szintén pozitívan befolyásolja a szájreklám dicséret jellegét, de negatívan hat a szájreklámmal kapcsolatos pozitív tevékenységre (Harrison-Walker, 2001).

A szolgáltatás javítás során a hiba oka és az észlelt disztributív és interakciós igazságosság hatással van az ügyfél-elégedettségre. A szolgáltatás javítás során továbbá az elégedettség (panasz) szintje magasabb (alacsonyabb) olyan helyzetekkel összehasonlítva, ahol nem történik szolgáltatási hiba (Hocutt et al., 1997). Ez tehát azt jelenti, hogy a vállalatok jelentősen képesek befolyásolni az ügyfélpanaszt a szolgáltatási hiba kezelési módjának megfelelően. 
A használat intenzitását telekommunikációban a havonta beszélt percek alapján határozzák meg (Bolton \& Lemon, 1999), amelyet a tudás és hozzáértés erősen befolyásol (Wangenheim, 2004). A szolgáltató és ügyfél közötti interakciós intenzitás növeli a használat gyakoriságát. Vagyis a közvetlen kommunikáció képes előrejelezni a jövőbeli szolgáltatás használatot, és az esetleges upgrade-et (Venkatesan \& Kumar, 2004). A vállalatoknak tehát érdemes a közvetlen kommunikációra ösztönöznie ügyfeleiket (Wangenheim, 2004).

\subsubsection{A SZOLGÁLTATÁSKIVEZETÉS VÁLLALATRA GYAKOROLT HATÁSA}

A bevétel megtakarítás és az innováció előmozdítása ösztönzi a vállalatokat leginkább a szolgáltatáskivezetés megvalósítására. A szolgáltatáskivezetés és ezen mutatóknak a kapcsolata nem mindig egyértelmü, amely csökkenti a vállalatok elkötelezettségét a szolgáltatáskivezetési stratégiákat illetően. Habár termékkivezetés esetén ezt a hatást a következőképpen határozták meg: , a termékfejlesztés növelheti az eladott mennyiséget és a profitot; a termékkivezetés ehhez hasonlóképpen nemcsak a 'gyenge’ termékek felesleges költségeit képes csökkenteni, hanem összességében képes a bevétel és a profit növelésére, az eröforrások reallokációja által, amely hatékonyabbá teszi a vállalatot” (Avlonitis, 1986, 1-2. o.).

Harness (2004) pénzügyi szolgáltatásoknál a kivezetés sikerességét a következő három fö területen fogalmazta meg: pénzügyi teljesítménnyel kapcsolatos előnyök (a kivezetés növeli a termékkör profitabilitását, a kivezetés csökkenti a kockázatot és költséget), menedzsment és a termék előállításával kapcsolatos előnyök (a kivezetés megszünteti a termékduplikációkat, lehetővé teszi új termékek bevezetését, felszabadítja a menedzsment idejét, javítja az értékesítés hatékonyságát, javítja az értékesítési portfólió egyensúlyát), és ügyfelekkel kapcsolatos előnyök (a kivezetés megszünteti az ügyfél számára zavaró termékeket, és az ügyfélpanaszok magas számát).

\subsubsection{A SZOLGÁLTATÁSKIVEZETÉS ÜGYFELEKRE GYAKOROLT HATÁSÁT MAGYARÁZÓ ELMÉLETEK}

Ahogyan a szakirodalmi áttekintés rávilágított arra, a szolgáltatáskivezetés ügyfél szempontjából meghatározott sikerességi tényezői terén jelentős kutatási rés azonosítható. Ahhoz, hogy megfelelően foglalkozzunk ezzel a területtel, most azokra az elméletekre fordítjuk figyelmünket, amelyek a szolgáltatáskivezetés ügyfelekre gyakorolt hatását magyarázzák.

A szakirodalomban tulajdonképpen két megközelítés található, amelyek az ügyfelek szolgáltatással kapcsolatos tapasztalatait értelmezik: az első megközelítés a társadalmi csere 
elmélet, amely az ügyfelek számára megjelenő költségekből indul ki, mert ezek a költségek képezik az élmény mérhető részét és nagy hatással vannak az ügyfelek értékelésére. A költségek föként azokat a gazdasági költségeket jelentik, amelyek a változás közvetlen pénzügyi hatásait fejezik ki, valamint pszichológiai költségeket, amelyek a változás minden nehezen vagy nem mérhető költségeit fejezik ki, mint például az idő, erőfeszítés, veszteség vagy szorongás érzete.

A másik megközelítés az igazságosság elmélet, amely kapcsolódik a társadalmi csere elmélethez, mivel ugyancsak az ügyfél értékelését elemzi az ügyfél tapasztalatát követően, de bizonyos értelemben tágabb fogalmakat használ a változások magyarázatára, a teljes folyamat igazságosságát alapul véve.

Az igazságosságnak számos dimenziója van, de az igazságosság leggyakoribb három eleme a disztributív, procedurális és interakciós igazságosság. Az igazságosság elmélet részben összefügg a társadalmi csere elmélettel, hiszen a disztributív igazságosság, a gazdasági költséghez hasonlóan, egy esemény során fellépő pénzügyi változásokat méri, míg a procedurális igazságosság a folyamattal kapcsolatos percepciókat ragadja meg, és az interakciós igazságosság pedig az ügyfél által észlelt interakció minőségére utal.

A következő részben ezeket a fogalmakat ismertetjük.

\subsubsection{TÁRSADALMI CSERE ELMÉLET}

Homans (1958) a társadalmi cserét úgy definiálja, mint „a javak, materiális javak és az immateriális javak cseréje, mint a jóváhagyás szimbólumai vagy a presztízs” (Homans, 1958, 606. o.). Blau (1964) hozzáteszi, hogy „,azokat a szivességeket is magában foglalja, amelyek jövőbeli kötelezettségekhez kötödnek (...) és a viszonzás jellege nem elcserélhetö”, és „,kizárólag a társadalmi csere képes olyan érzelmek kiváltására, mint a személyes kötelezettség, hála vagy bizalom; amelyre a tisztán gazdasági csere nem képes” (Blau, 1964, 93-94. о.).

Ez megmagyarázza, hogy a társadalmi csere során a gazdasági költségek mellett pszichológiai költségek is felmerülnek, valamint az ügyfélmegtartásra gyakorolt hatásukat is segít értelmezni. Ezeket a költségeket használjuk a szolgáltatáskivezetés ügyfelekre gyakorolt hatásának mérésére. A társadalmi csere emellett segíthet annak megértésében is, hogy a procedurális és interakciós igazságosság között melyek azok a közvetítő változók, amelyek meghatározzák az ügyfél reakciókat (Masterson et al., 2000). Szolgáltatáskivezetés esetén a társadalmi csere a szolgáltató vállalat és ügyfél közötti kapcsolatra utal. 
A társadalmi csere elmélet a csere paradigmához is kötődik: javak vesznek részt a cserében; a javak értéke, hasznossága és az azokhoz kapcsolódó ellenszolgáltatás egyaránt lehet személyes vagy piachoz kötődő és idővel változhat, a negatív érték pedig költséget jelent; és a tranzakció legalább két szereplő részvételével történik (Carman, 1980).

A társadalmi csere elmélete a társadalmi státuszhoz, befolyáshoz, szociális hálókhoz, igazságossághoz, koalíció formálásához, szolidaritáshoz, bizalomhoz, érzelemhez vagy indulathoz is kötődik (Cook et al., 2003). Számunkra a társadalmi csere elmélet és az igazságosság közötti kapcsolat releváns, amely a csere érzelmi oldalát emeli ki (Jasso, 2006).

Homburg és szerzőtársai (2010) szerint „egy termék kivezetése súlyos gazdasági és pszichológiai költségekkel járhat az ügyfelek számára, ezáltal jelentösen csökkentve az ügyfélelégedettséget és lojalitást”" (Homburg et al., 2010, 531. o.)

A gazdasági költség „, a termékkivezetés miatt fellépö, az ügyfél által észlelt gazdasági teher mértékét fejezi ki” (Homburg et al., 2010, 533. o.) A pszichológiai költség a társadalmi cseréhez köthetö összes észlelt költség (pl. szolgáltatóvállalat-ügyfél kapcsolatában), amely az idő során felmerül, emellett az a bizonytalanság vagy kockázat, amely a még nem használt márkával kapcsolatban felmerül, hiszen az ügyfél magas költséget észlel egy olyan márkát illetően, amelyet még nem használt korábban (Sharma \& Patterson, 2000). A kockázat különösképpen szolgáltatások esetében lép fel, ha az ügyfelek egy versenytársat részesítenek előnyben, hiszen a szolgáltatásminőség a vásárlás előtt nem értékelhető (Sharma et al., 1997). A pszichológiai költségek relevánsak szolgáltatáskivezetés esetében, mivel a kivezetés miatt az ügyfélnek értékelnie kell a versenytársak ajánlatait. Ez a migrációval kapcsolatos bizonytalanság az ügyfél számára a szolgáltatás értékelésének kockázatával, a vállalat számára pedig lemorzsolódási kockázattal jár.

Foa és Foa $(1974 ; 1980)$ a gazdasági és pszichológiai költségek közti különbséget a következőképpen írják le: a gazdasági költség és a csere előnyei tekinthetőek egy csere „hard faktorai”- nak, a pszichológiai költségek és előnyök pedig a „soft faktorok”, mint például a megbízhatóság, rugalmasság, és együttmüködési képesség.

A szolgáltatáskivezetés és a folyamattal kapcsolatos költségek hatással vannak az ügyfélmegtartásra: „, a kivezetés pszichológiai költségei tükrözik az ügyfél a termékkivezetés következtében kialakuló elbizonytalanodását a szolgáltatóvállalattal kapcsolatban, hiszen a kivezetés az ügyfélben kétségeket ébreszthet a szolgáltatóval való üzleti kapcsolat helyességét illetöen” (Homburg et al., 2010, 533. o.). 
A váltási költség a gazdasági, pszichológiai és fizikai költségek összessége (Jackson, 1985). A gazdasági vagy pénzügyi váltási költség az az elsüllyedt költség, amely az ügyfél márka iránti elköteleződésekor merül fel, mint például a számla megszüntetésének költségei a szolgáltatónál, vagy a szolgáltató versenytársánál való számla nyitásának költségei (Klemperer, 1987).

A gazdasági és pszichológiai költségek a váltási költségek elméletéhez kapcsolódnak, amelyek nemcsak a pénzügyi jellegü költségeket tartalmazzák, hanem azokat is, amelyek az új vállalat ügyfelévé válás pszichológiai hatását fejezik ki, valamint az új márka megvásárlásához szükséges befektetett időt és energiát (Klemperer, 1995; Kim et al., 2003). Ilyen értelemben a szolgáltatáskivezetés hasonló helyzetet eredményezhet az ügyfél számára, hiszen amennyiben az új ajánlat nem elfogadható számára, az ügyfél a szolgáltató versenytársainak ajánlatait kell, hogy mérlegelje, amely döntésben azonban jelentős szerepe van a váltási költségeknek.

A szolgáltatáskivezetés esetén az ügyfél számára felmerülő költségek a társadalmi csere elméletre alapulnak, amely jelentősen befolyásolja a szolgáltatáskivezetés végső kimenetét. Vagyis a társadalmi csere elmélet segít a szolgáltatáskivezetést követő ügyfélreakciók megértésében.

\subsubsection{IGAZSÁGOSSÁG ELMÉLET}

A következő részben az igazságosság elmélet alkalmazásával kapcsolatos, szolgáltatási hiba területéről származó eredményeket foglaljuk össze, majd értelmezzük azok relevanciáját a szolgáltatáskivezetéssel összefüggésben.

Az igazságosság elmélet kutatásunk szempontjából releváns szolgáltatásmarketing koncepció, amelyet elsősorban a szolgáltatás helyreállítás (service recovery) területén alkalmaztak (Andreassen, 2001; Wirtz \& Mattila, 2004), és amely a lojalitás eszközének is tekinthető. Boshoff és szerzőtársai (2000) a szolgáltatás helyreállítást a következőképpen definiálják: „A vállalat olyan eröfeszitései, amelyek a sértett fogyasztókat az elégedettség állapotába próbálják meg visszajuttatni szolgáltatási hibát követően” (Boshoff \& Allen, 2000, 63. o.). Annak ellenére, hogy a szolgáltatáskivezetés nem szolgáltatási hiba, mégis ahhoz hasonlóan, negatív attitüdöt és panaszt válthat ki az ügyfelekből, amelyek a szolgáltatáskivezetés nem megfelelő kezelése esetén az ügyfelek lemorzsolódásához vezethetnek.

A szolgáltatáskivezetés hatásának elemzése szempontjából az igazságosság három formája releváns: disztributív, procedurális és interakciós igazságosság. A disztribúciós 
igazságosság a kimenetelre utal, míg a procedurális igazságosság a folyamatok, irányelvek és szabályok összességét fejezi ki (Smith et al., 1999), az interakciós igazságosság pedig magában foglalja a bocsánatkérést, észlelt segítőkészséget, udvariasságot és a szolgáltató személyzet empátiáját is (Wirtz \& Mattila, 2004).

A disztributív igazságosságot gyakran kimeneti igazságosságnak is nevezik, mivel az ügyfél által kapott kárpótlásra vagy kompenzációra vonatkozik. Ez nemcsak a hibát, de az időt, erőfeszítéseket és energiát is kompenzálja a szolgáltatás helyreállítás teljes folyamata alatt (Wirtz \& Lovelock, 2016). A procedurális igazságosság befolyásolja az interakciós igazságosságot, amely végül hatással van a kimeneti igazságosságra, amelyek összességében kialakítják a szolgáltatás helyreállításával kapcsolatos elégedettséget (Tax \& Brown, 1998).

Az igazságosság elmélet szervezeten belüli hatása az elégedettségre és elkötelezettségre gyakori kutatási téma (McFarlin \& Sweeney, 1992; Moorman et al., 1993; Martin \& Bennett, 1996; Bakhshi et al., 2009), de a szervezet és ügyfél kapcsolatában szintén megjelenik (Tax \& Brown, 1998; Smith et al., 1999; Davidow, 2003). Kutatásunk az utóbbihoz kapcsolódik.

További kutatási területek az igazságosság elmélet és a vevőkör kedvező szándékai, valamint a negatív szájreklám valószínüségének csökkenése közötti kapcsolat (Blodgett et al., 1997). Egy másik fontos kutatási kérdés a szolgáltatás helyreállítási eszközeinek helyes arányát érinti. Wirtz és Mattila eredményei (2004) azt mutatják, hogy a kompenzáció nem mindig szükséges a procedurális és interakciós igazságosság miatt: a szolgáltatási hiba esetén kialakított azonnali helyreállítás és bocsánatkérés a kompenzációt már szükségtelenné teszi, viszont a kompenzációnak nincs hatása, ha az ügyfél procedurális és interakciós igazságtalanságot tapasztal a folyamat során. A kompenzáció csak akkor befolyásolta az ügyfélelégedettséget, ha egy azonnali helyreállítás történt bocsánatkérés nélkül vagy egy a reakció késleltetett volt bocsánatkéréssel kiegészítve. Ez azt jelenti, hogy az azonnali helyreállítás bocsánatkéréssel, és kompenzáció nélkül lehet a legkielégítőbb és leginkább költségkímélő megoldás a vállalatok számára.

Az igazságosság elmélet alapján az ügyfél percepciót megkülönböztethetjük az erkölcsi normákat illetően (minek kellett volna történnie) és a disztributív, procedurális és interakciós igazságosság által kiváltott érzések tekintetében (McColl-Kennedy \& Sparks, 2003).

Az igazságosság percepcióját meghatározza a szervezeti válasz (kompenzáció, kedvező alkalmazotti magatartás, szervezeti folyamatok), és emellett hatással van a panaszt követő elégedettségre is, amely befolyással van az ügyfél viselkedési szándékára (lojalitás és pozitív 
szájreklám), ahogyan azt 7. ábra is mutatja (Gelbrich \& Roschk, 2011). Ezeket a változókat használjuk a szolgáltatáskivezetés ügyfelekre gyakorolt hatásának mérésére.

\section{7. ábra: A panaszt követő viselkedés meta-analitikus kerete}

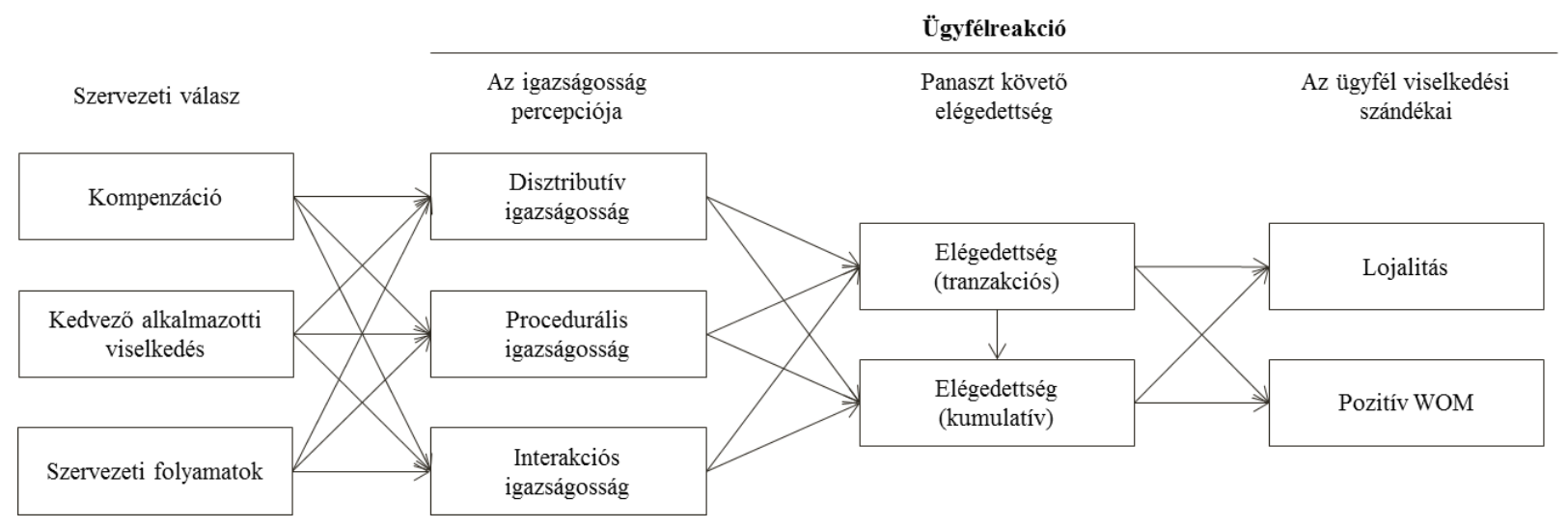

Forrás: Gelbrich \& Roschk (2011: 25. o.)

A szolgáltatás helyreállításához használt eszközök és az igazságosság elmélet hozzájárulnak az ügyfelek panasszal összefüggő magatartásának megértéséhez, amely a szolgáltatáskivezetés esetében is egy lehetséges kimenet, és érintheti a lemorzsolódást.

Összességében elmondhatjuk, hogy a szolgáltatás helyreállítás és igazságosság elmélet megértése hozzájárulnak a szolgáltatáskivezetés kivitelezési módjának (igazságosság) megismeréséhez és az ügyfelekre gyakorolt pozitív vagy negatív hatásának értelmezéséhez.

\subsection{TELEKOMMUNIKÁCIÓ}

A telekommunikációs ügyfelek bizonyos értelemben olyanok, mint bármilyen más szolgáltatás ügyfelei, mint például a pénzügyi szektorban, mert a vásárlást a szolgáltatás sajátosságai határozzák meg, amelyet a HIPI-elv ír le (Zeithaml et al., 1985). Kizárólag a szolgáltatások különböznek egymástól, és ebből adódóan a használati szokások is eltérőek lehetnek. Ezért célunk annak feltárása, hogy melyek azok a területek, ahol a telekommunikációs szolgáltatáskivezetés eltér a szolgáltatáskivezetés pénzügyi kontextusban való értelmezésétől, amely a szolgáltatáskivezetés szakirodalomban leggyakrabban vizsgált terület. Egy fontos különbség, hogy az ügyfél szolgáltatóval való hosszú távú kapcsolata a hálózathoz való csatlakozást követően a legfontosabb a telekommunikációban, bármely más szektorral összehasonlítva (Gerpott et al., 2001). Ez a hálózati hatással magyarázható, azzal a kiegészítéssel, hogy ennek a jelentősége stagnáló piacokon fokozatosan csökken.

$\mathrm{Az}$ 1.3. fejezetben bemutattuk, hogy a telekommunikáció miért ideális a szolgáltatáskivezetés tanulmányozásához, egyrészt a területen elérhető limitált számú kutatási eredmény, másrészt a gyakorlati relevancia fokozatos növekedése miatt. A 
szolgáltatáskivezetés telekommunikációs kontextusban való tanulmányozásához ebben a fejezetben áttekintjük az általános telekommunikációs szakirodalmat, a szolgáltatáskivezetéssel közös koncepciókra fókuszálva.

A telekommunikációs szektort többek között annak gyakorlati relevanciája miatt használjuk kutatásunkban: egyrészről a telekommunikációs szolgáltatóknak nehézséget jelent a megfelelő szolgáltatáskivezetési stratégia megválasztása az ügyfelek és a bevétel jelentős részének elvesztése nélkül, másfelől az ügyfelek számára ez egy nehéz döntés, amely mindennapi életüket érinti. Emellett a telekommunikációs szolgáltatások rövid életciklusa miatt a szolgáltatáskivezetés minden eddiginél népszerübb gyakorlattá vált. Ezt fontos kérdésnek tekintjük, és a folyamat és annak eredménye például a vállalatok adatbázis elemzésén keresztül jelentősen javítható. Vagyis a telekommunikációs szektor megfelelő a szolgáltatáskivezetés elemzéséhez, ideális a szolgáltatások különleges tulajdonságainak megértéséhez szolgáltatáskivezetés esetén. Ezáltal a pénzügyi szektort és több szektort érintő tanulmányok eredményei is gazdagíthatóak.

A telekommunikációs szolgáltatás „az alap telefonokra és internet hozzáféréssel rendelkezö számitógépekre utal a fejlödö országokban, a szélessávú internet hozzáférésre a fejlett országokban, valamint a számitógép alapú alkalmazásokra a telekommunikációs szolgáltatások esetében” (Ramírez \& Richardson, 2005, 298. o.). A telekommunikációs szolgáltatások hozzájárulnak a társadalmi, gazdasági és életminőségi dimenziókhoz, amelyek kölcsönös kapcsolatban állnak egymással (Hillier, 2000).

A magyar telekommunikációs piacon világos tendencia rajzolódik ki: a hang előfizetések erősen csökkennek (Analysis Mason, 2014), viszonylag állandó piaci részesedésekkel a három szolgáltató esetében (Telekom, Telenor és Vodafone). A lemorzsolódás tekintetében (nem szolgáltatáskivezetési szituációkban, hanem általánosságban), az NMHH (Nemzeti Média és Hírközlési Hatóság) számos eredményt közöl (NMHH, 2013). Meglepő módon a pre-post migráció (kártyás- előfizetéses irányú migráció) nagyon alacsony, mindössze 2\%. Az ügyfelek 5\%-a szüntette meg az elöfizetését, 4\%-a váltott egy másik szolgáltató kedvezőbb ajánlata miatt. Ami az ügyfelek migrációját illeti, az új belépők száma nagyon alacsony (1\%), a migráció inkább azok esetében jellemző, akik már rendelkeznek elöfizetéssel, de a többség nem migrál. Ez azt is jelzi, hogy a szolgáltatáskivezetés esetében jelentkező lemorzsolódás nem becsülhető meg az általános lemorzsolódási modellek alapján, mert azok nem tartalmaznak minden releváns tényezőt, 
amely fontos lehet az ügyfélreakció szempontjából, a szolgáltatáskivezetés végső kimenetére való hatásuk miatt.

$\mathrm{Az}$ átlagos (price independent churn) lemorzsolódási ráta a telekommunikációs szektorban 2-4\% között van havonta (Aydin \& Özer, 2005), amely nagy mennyiségü elveszett bevételt jelent a vállalatok számára. Palmer (1998) az Orange példáján keresztül mutatja be a jelenséget, ahol az új ügyfelek megszerzésének költsége 256 font, amely alapján a 20\%-os lemorzsolódási ráta 10\%-osra való csökkentése 25 millió font éves megtakarítást eredményezett volna a vállalat számára. Habár a hang trendek azóta már jelentősen átalakultak a telekommunikációs szektorban, az új ügyfél szerzésének költsége jelenleg 315 dollár (Entrepreneur, 2017) körül van. Vagyis a lemorzsolódás menedzselése kulcsfontosságú a telekommunikációs szektorban, nemcsak a magas ügyfélszerzési költségek, hanem a stagnáló piacok miatt egyaránt.

Ez a tendencia az új ügyfélszerzés nehézségeire világít rá, amely kizárólag abban az esetben lehetséges, ha a szolgáltatók meggyőzik potenciális ügyfeleiket arról, hogy érdemes szolgáltatót váltaniuk, vagy az ügyfélmegtartási stratégiáikat erősítik, amely utóbbi felértékelődik jelen piaci körülmények között. Ezért fontos a fogyasztói preferenciák minél pontosabb vizsgálata, és ezáltal a szolgáltatáskivezetés az ügyfélmegtartás egy lehetséges eszközévé válhat, azzal a kiegészítéssel, hogy a szolgáltatóknak már nem csak az akvizícióra, hanem sokkal inkább az ügyfélmegtartásra kellene összpontosítaniuk.

A szakirodalmi áttekintés alapján az általános ügyfélelégedettség lojalitásra, és annak ügyfélmegtartásra való hatása egyértelmü. Telekommunikációs kontextusban szolgáltatói oldalról a mobil szolgáltatás díja, a személyes szolgáltatás előnyeivel kapcsolatos percepció, és a számhordozás állnak a legszorosabb kapcsolatban az ügyfélmegtartással (Gerpott et al., 2001).

Vagyis mindezek alapján úgy gondoljuk, hogy stagnáló piacokon, amilyen a középeurópai régió is, a szolgáltatóknak új típusú szolgáltatásportfóliót kell létrehozniuk, ahol a szolgáltatáskivezetés kulcsfontosságú szerepet kap: a szolgáltatáskivezetés a portfólió innováció előfeltétele, vagyis a szolgáltatások kivezetése révén a teljes szolgáltatásportfólió átalakítása lehetővé válik, annak ellenére, hogy ez még egy meglehetősen elhanyagolt terület a gyakorlatban.

\subsubsection{A TELEKOMMUNIKÁCIÓS PIAC SZERKEZETE A KÖZÉP-EURÓPAI RÉGIÓBAN}

Tanulmányunk kontextusa a közép-kelet-európai régió telekommunikációs piaca, de elsősorban a szolgáltatáskivezetés telekommunikációs sajátosságait elemezzük és nem áll 
szándékunkban a teljes régióra vonatkozó általános eredmények megfogalmazása. Ennek ellenére a közép-kelet-európai régió meghatározza eredményeink bizonyos aspektusait, kiemelten a régió telekommunikációs piacának telítettsége miatt. A régióban található országok hasonlóak bizonyos szempontból, amely meghatározza a mai telekommunikációs piacok kialakulását. Úgy látjuk, hogy a piaci szereplők piacra lépése és a piaci dinamika szignifikánsan befolyásolja a szolgáltatók versenyelőny fenntartását megcélzó stratégiáinak kialakítását. Manapság az akvizíciós stratégia már elavultnak tünik, elsősorban a piacon elérhető potenciális ügyfelek csökkenő száma miatt. Az ügyfélmegtartásnak sokkal nagyobb szerepe kellene, hogy legyen, amely a szolgáltatáskivezetés esetében is kulcsfontosságú.

A teljes GDP arányában a telekommunikáció mindössze 1\% volt Csehországban és Magyarországon 1995-ben, amely jóval az OECD átlag alatt maradt (2\% alatt) (International Telecommunications Union, 1995). A telekommunikációs szolgáltatásokból származó bevétel a becslések szerint 2019-re a nominális GDP 1,2\%-ára fog csökkenni a közép-kelet-európai régióban (2013-ban 2,1\% volt ez az arány), amely jórészt a piac érettségének tudható be, Nyugat-Európához hasonlóan (Analysis Mason, 2014).

Ahogyan más innovációk esetében, a telekommunikációs szektorban is egyre több vállalat gyorsította fel az innováció elterjedését, amely a közgazdaságtani szakirodalomban jól ismert jelenség (Reinganum, 1989). A telekommunikációs ipar szintén a természetes monopólium állapotából indult, de az analóg technológiákról digitálisra történő váltás kiterjesztette a piac méretét (Calhoun, 1988).

Kezdetben, az ár kialakítása a telekommunikációs szektorban nem hatékony erőforrás allokációt eredményezett, elsősorban a politikai célok miatt. Ezzel párhuzamosan, a szolgáltatásminőség nagyon gyenge volt, sok dobott hívással, gyakori leállásokkal és hosszú várakozási időkkel. A telefonvonalankénti bevételek nagyon alacsonyak voltak és az árakat nem igazították a költségekhez. Ezek a tényezők vezettek a telekommunikációs piac nem hatékonyként való megítéléséhez a kommunista időkben, amelyet csak tovább súlyosbítottak a piacon megjelenő korlátozások (Coordinating Committee for Multilateral Export ControlsCOCOM, Multilaterális Exportkorlátozásért Felelős Bizottság) és a valuta hiánya. Vagyis az egyéni felhasználók igényeit gyakorlatilag figyelmen kívül hagyták. A kommunizmus végét követően jelentős erőfeszítéseket tettek az infrastruktúra modernizálása érdekében, mégis a fő vonalak 100 lakosra eső aránya még mindig jóval alacsonyabb volt a közép-kelet-európai régióban (35 200-ben), mint az EU-s átlag (51 1997-ben). Az ügyfelek alacsony árakkal kapcsolatos elvárásai is alakítják a közép-kelet-európai régió telekommunikációs környezetét. 
A vezetékes vonalak rendszerének megszünésével a mobilkommunikációs technológia alacsonyabb belépési korlátokat tett lehetővé a szolgáltatók számára, és így a piacok a versenyhelyzet felé mozdulhattak el a monopolista piacszerkezet felől. Ez a változás elsősorban az analóg technológia digitálisra való váltásával következett be (Gruber, 2001).

A technológiák evolúcióját tekintve, Közép-Kelet-Európa ugyanazt az analóg rendszert használta minden országban, mint a nyugat-európai országok. Az 1990-es évek elején a digitális technológia kezdett elterjedni, amely a digitális terjeszkedés mozgatórugója volt: az Európai Unióban 1997-re a piac kétharmadát a digitális technológia uralta, míg 1995-ben még a piac felét sem érte el. A közép-kelet európai országok között viszont nagy eltérések voltak a penetrációs rátákat tekintve (Gruber \& Verboven, 2001).

A mai piacszerkezet szempontjából érdekes, hogy a GSM technológiát a legtöbb középkelet-európai országban duopolista formában vezették be (Szlovéniában és Bulgáriában volt kizárólag egy, Észtországban pedig három szolgáltató). A belépés módja azonban meghatározza a piaci verseny szintjét, és ilyen tekintetben megállapítható, hogy minden országban szekvenciális belépés történt, nem egyidejü (5. táblázat). Ez megmagyarázza egyfelől a minden országban jellemzően egy domináns szolgáltató jelenlétét, valamint a további belépők piacszerzési nehézségeit. Ez sok esetben arra is rávilágít, hogy az új ügyfélszerzési folyamat miért nem hatékony. Ilyen piaci körülmények között az ügyfélmegtartásnak kulcsfontosságú szerepe van, mégis elsősorban az akvizíció a szolgáltatók elsődleges célja. A szolgáltatáskivezetés szempontjából ez fontos következményekkel jár: a folyamat nem hatékony müködése által elveszített ügyfelek esetlegesen nem szerezhetőek meg újra, vagy csak nagyon magas költségekkel.

Habár az egyidejű belépés előnyeit nem tudták teljes mértékben igazolni, jelentős piaci aszimmetriák számos országban előfordultak, mint például Magyarországon, Lengyelországban, Romániában és Szlovákiában (Gruber, 2001).

\section{5. táblázat: A közép-kelet-európai vállalatok mobil telekommunikációs}

szolgáltatásainak indulási időpontjai

\begin{tabular}{|l|l|l|l|l|}
\hline & \multicolumn{1}{|c|}{ Analóg } & \multicolumn{1}{c|}{ GSM 1 } & \multicolumn{1}{c|}{ GSM 2 } & GSM 3 \\
\hline Bulgária & 1993. december & 1995. szeptember & & \\
\hline Cseh Köztársaság & 1991. szeptember & 1996. július & 1996. szeptember & \\
\hline Észtország & 1991. január & 1993. szeptember & 1995. január & 1997. május \\
\hline Lettország & 1991. október & 1995. január & 1997. március & \\
\hline Litvánia & 1992. február & 1995. március & 1995. október & \\
\hline Lengyelország & 1992. június & 1996. szeptember & 1996. október & \\
\hline
\end{tabular}




\begin{tabular}{|l|l|l|l|l|}
\hline Magyarország & 1990. október & 1994. március & 1994. április & \\
\hline Románia & 1993. május & 1997. április & 1997. június & \\
\hline Szlovákia. & 1991. szeptember & 1997. január & 1997. február & \\
\hline Szlovénia & 1990. október & 1996. július & & \\
\hline
\end{tabular}

Forrás: Gruber (2001, 26. o.)

Napjainkban a 2G, 3G és 4G, valamint az 5G még ezidáig nehezen felmérhető előnyei felé mozdul el a piac. A hozzáférés lehetősége legtöbbször már nem kérdés, sokkal inkább az, hogy a szolgáltatók hogyan tudják szolgáltatásportfóliójukat a jelenlegi igényeknek megfelelően átalakítani. A hang alapú trendek már tulajdonképpen nem relevánsak, az adatból származó bevételek aránya várhatóan 25\% körül lesz 2018-ra (Analysis Mason, 2014), amely fokozatosan növekszik.

Az a kérdés, hogy a telekommunikációs vállalatoknak milyen túlélési stratégiát kellene választaniuk ilyen telített piacokon? Az ügyfélelégedettség és a váltási korlátok hatással vannak a lojalitásra (Kim et al., 2004), amelyek a lojalitás soft és hard tényezőjének is tekinthetőek. Az ügyfélelégedettséget a szolgáltatásminőség (hívásminőség, értéknövelt szolgáltatások, ügyféltámogatás) és a váltási költségek (veszteség költsége, belépési költségek, interperszonális költségek) (Kim et al., 2004) határozzák meg.

A válasz valószínüleg ezek kombinációjából áll, de hiszünk abban, ahogyan a szolgáltatáskivezetés szolgáltatáskutatási prioritásokkal való kapcsolata is kiemelte, a szolgáltatásinnováció a co-creation-nel kombinálva együttesen meghatározzák napjaink fő stratégiáját, vagyis a telekommunikációs szolgáltatóknak valószínűleg ezt az irányt érdemes követniük. A telekommunikációs szolgáltatásoknak azonban számos olyan különleges tulajdonságuk van, amelyek meghatározzák az ügyfelek lojalitását, az egyik közülük a szolgáltatások rövid életciklusa, amely erősen kapcsolódik az innovációhoz.

\subsubsection{A SZOLGÁLTATÁSOK ÉLETCIKLUSA}

A szolgáltatások életciklusa erős hatással van a szolgáltatáskivezetés időzítésére és kivitelezésére egyaránt, vagyis releváns telekommunikációban végzett kutatásunk szempontjából.

A termék életciklus modelljét eredetileg termékekre fejlesztették ki, nem szolgáltatásokra (Abernathy, 1978; Abernathy \& Utterback, 1979; Utterback, 1994). A modell megkülönbözteti az új termék érettségének három szakaszát: folyékony (fluid), átmeneti és specifikus (Utterback, 1994). A folyékony szakaszt a design domináns formája választja el az átmeneti és specifikus szakasztól. A design domináns formája a termelők és/vagy ügyfelek 
választásának eredménye, és két aspektusa van: a technikai a termék vagy szolgáltatás fö konfigurációját, míg a funkcionális a felhasználók terméktulajdonságokkal kapcsolatos preferenciát fejezi ki (Cusumano et al., 1992). Az átmeneti fázisban a vállalat orientációja a termékinnovációról folyamatinnovációra változik, majd a specifikus (érett) fázisban a verseny a megkülönböztetett termékekre vagy szolgáltatásokra fókuszál (Cusumano et al., 1992; Van Den Ende, 2003).

Mindezek alapján a mobilszolgáltató új szolgáltatása akkor tekinthető folyékony szakaszban lévőnek, ha olyan új tulajdonságokat hoz létre, amelyek új piacokat teremtenek (pl. lokáció alapú szolgáltatások). Az átmeneti vagy érett fázisok azokat a fejlesztéseket foglalják magukban, amelyek a meglévő szolgáltatások bizonyos szempontból vett másolatainak tekinthetőek, amelyeket a vállalat már más csatornákon keresztül értékesít (pl. elektronikus telefonkönyv). A technológiai és piaci bizonytalanság a folyékony szakaszban a legmagasabb, és az érett fázisban a legalacsonyabb. Az életciklus perspektíva egy másik vetülete a termék és szolgáltatásfejlesztés sürgőssége. A sürgősség az innovátor számára a termékfejlesztés időben való elvégzését és a design domináns formájának megszerzését fejezi ki (Lambe \& Spekman, 1997). A folyékony szakaszban a telekommunikációs piac definíció szerint nagy bizonytalanságú és sürgősségű szolgáltatásokkal rendelkezik (Van Den Ende, 2003).

A szolgáltatásmenedzsment telekommunikációban a szolgáltatások létrehozását, felügyeletét, frissítését és kivonását jelenti (Brunner \& Stadler, 1999), amely a szolgáltatás életciklusához is kapcsolódik, beleértve a design, tárgyalási, felkészülési (provisioning), használati és deinstallációs fázisokat (Garschhammer et al., 2001) egyaránt. A design szakaszban a szükséges funkcionalitás specifikálása, a szolgáltatásminőségi paraméterek (Quality of Service, QoS), költségbecslés, potenciális ügyfelek (új ügyfelek, gross add, migráció és lemorzsolódás), megtérülés és költségek becslése történik. A szolgáltatás létrehozása után történik a szolgáltatási ajánlattétel az ügyfél számára a tárgyalási szakasszal indulva, ahol az összes használattal kapcsolatos paraméter egyeztetésére sor kerül (pl. szolgáltatás ára, kedvezmények, QoS, büntetések, stb.). A szolgáltatás a felkészülési szakaszban kerül bevezetésre, amely a szolgáltatás implementációját, konfigurációját és tesztelését jelenti, és az ügyfél által aláírt elfogadási nyilatkozattal zárul. A használati szakasz a müködést jelenti, amely minden, a kiválasztott szolgáltatás normál használatát támogató szolgáltatást magában foglalja (támogatás, felügyelet, karbantartás, riportolás, számlázás, stb.), ezeken kívül a szolgáltatás funkcionalitásának, minőségének és más paramétereinek esetleges változásaira is kiterjed. Az eredeti szerződésben megfogalmazott változások miatt akár egy 
kiegészítő szolgáltatási megállapodás is szükségessé válhat. Az utolsó fázis a deinstalláció, amely a szolgáltatás végét jelenti, a teljes implementáció eltávolításával és az érintett erőforrások felszabadításával (Garschhammer et al., 2001). A szolgáltatáskivezetés kizárólag a deinstallációs fázissal foglalkozik.

Yelmo és szerzőtársai (2007) hozzáteszik, hogy a deinstallációs fázis- általuk hívás szolgáltatás visszavonásaként definiált- feladatai a következőek: deaktiválás, közzététel megszüntetése, regisztráció megszüntetése, a felkészülés (provisioning) megszüntetése és a fizikai eltávolítás. A szolgáltatáskivezetést nem említik a kivonás okai között, kizárólag a helyettesítést vagy a szolgáltatás evolúcióját feltételezik.

Világszerte rövidülő termék és szolgáltatás életciklus dominálja a gazdaságot, amelynek eredménye a gyors termékinnovációs ciklusok és az egyre összetettebb termelési és értéklánc partnerkapcsolatok. Az új technológiákat szintén egyre gyorsabban fogadják el a telekommunikációs szektorban, amelyek sokkal gyorsabban cserélődnek más technológiai piacokkal összehasonlításban, és ez végül a termékek rövid életciklusához vezet (Wu et al., 2006). 


\section{KUTATÁSI KÉRDÉSEK ÉS MÓDSZERTAN}

„Az új eredményeket soha nem elég csak elmondani az embereknek... Ahelyett, hogy az emberek fejébe töltenénk a tudást, segitenünk kell nekik új típusú szemüvegen keresztül, másképpen látni a világot.

Ennek része a rejtett feltételezések megkérdőjelezése, amelyek meghatározták, hogy az emberek az idök folyamán hogyan tekintettek bizonyos dolgokra."

(John Seely Brown, idézi: Wirtz-Lovelock, 2016: 4. o.)

A kutatásunkhoz kapcsolódó fö fogalmak és a szakirodalmi rések áttekintése után ebben a fejezetben a koncepcionális keretet, kutatási kérdéseket, hipotéziseket és módszertant mutatjuk be, amely három tanulmányból áll.

\subsection{KONCEPCIONÁLIS KERET}

A szakirodalmi áttekintés alapján megalkotjuk a szolgáltatáskivezetés koncepcionális keretét, amelyet a kutatási módszertan kialakításának alapjául használunk (8. ábra). A szakirodalmi áttekintés egyik megállapítása az, hogy a szolgáltatáskivezetésnek három fő szakasza van: a szolgáltatáskivezetés okai, a folyamat indikátorai és következményei.

Egy átfogó koncepcionális keretet használunk a szolgáltatáskivezetés előzményeinek, folyamatának és hatásának áttekintésére. A szolgáltatáskivezetés előzményei magában foglalják a folyamathoz vezető okokat (pl. értékesítés visszaesése, alacsony nyereség ráták, új termékportfólió bevezetése, rövidebb szolgáltatás életciklus, az anyavállalat döntése, stb.), és a mozgatórugókat ( $\mathrm{pl}$. technológia, globális trendek). Az előzmények befolyásolják a szolgáltatáskivezetés fó tulajdonságait (pl. a szolgáltatáskivezetési folyamatot, a stratégiai szintű szolgáltatáskivezetést, az ügyfelek kezelését, gazdasági és pszichológiai költségeket, igazságosság teljesülését, stb.), amelyek az ügyfelet (lemorzsolódás, elégedettség, lojalitás, affektív és kalkulatív elkötelezettség, szájreklám) és a vállalatot (ügyfél menedzsment, fenntartási és fejlesztési költségek, a menedzsment és sales által tett erőfeszítések, erőforrás menedzsment, a szolgáltatásportfólió teljesítménye) egyaránt befolyásolják. A korlátok (pl. jogi környezet, kormányzati szabályozás, az elavult szolgáltatások átalakítása) moderáló tényezőként hatnak a szolgáltatáskivezetés előzményei és a szolgáltatáskivezetés tulajdonságai közötti kapcsolatra.

A szolgáltatáskivezetés kutatásban az ügyfelekre és vállalatokra gyakorolt hatás kulcsfontosságú, mert ezeken a területeken mérhető elsősorban a szolgáltatáskivezetés sikeressége. Kutatásunkban a szolgáltatáskivezetés ügyfelekre gyakorolt hatására összpontosítunk. 
Ahogyan a szolgáltatáskivezetés definíciójánál hangsúlyoztuk, kutatásunkban a teljes, nem részleges kivezetést vizsgáljuk, vagyis a sikerességet a szolgáltatáskivezetés után a vállalatnál maradó ügyfelek arányával definiáljuk.

\section{8. ábra: A szolgáltatáskivezetés koncepcionális kerete}

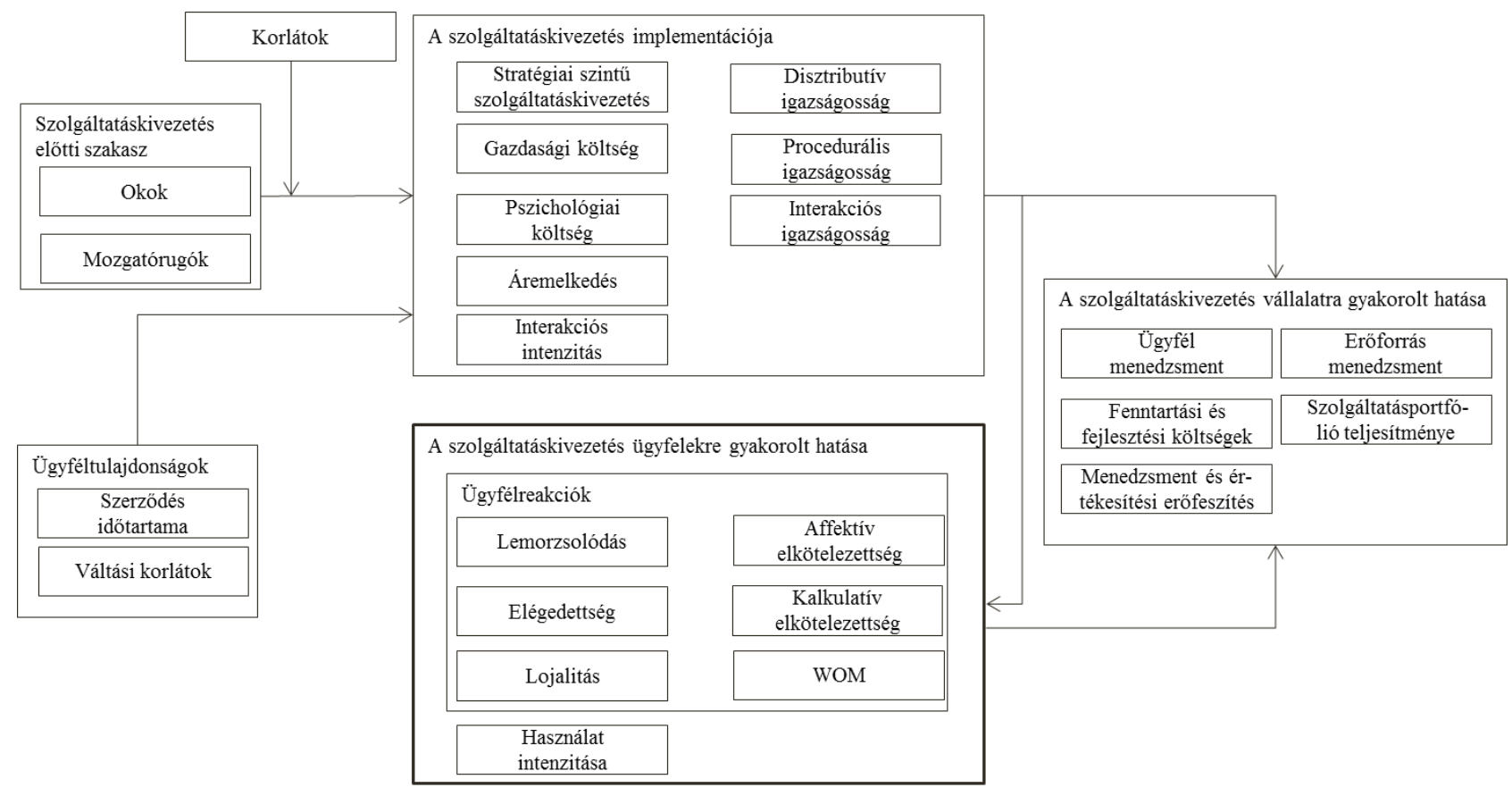

Forrás: saját szerkesztés

\subsection{ESETTANULMÁNY: KVALITATÍV KUTATÁS}

Mivel a szakirodalomban a szolgáltatáskivezetés ügyfél oldali elemzésére vonatkozóan kevés empirikus eredmény érhető el, ezért egy esettanulmányt készítettünk a téma fő területeinek feltárására. Ezért elsőként az esettanulmány eredményeit mutatjuk be, amelyeket a módszertan kidolgozására használunk fel. Azt szeretnénk elsősorban megérteni, hogy a vállalatok számára valóban az ügyfelek elvesztésének kockázatával jár-e a szolgáltatáskivezetés, melyek a szolgáltatáskivezetési stratégiának az okai, valamint a teljes folyamat hogyan épül fel. Tehát az esettanulmány célja a szolgáltatáskivezetési stratégiák telekommunikációs szektorban történő elemzése, mert ideálisnak tekinthető a szolgáltatások különleges tulajdonságainak megértéséhez. A szolgáltatáskivezetés stratégiai szintű okait vizsgáljuk mélyinterjúk segítségével. A kvalitatív kutatás ideális a szolgáltatáskivezetés okainak, folyamatainak és eredményének vizsgálatához. Célunk a fö fogalmak, problémák azonosítása a folyamat során, amely hozzájárul a szolgáltatáskivezetés sikerességének fejlesztéséhez. 
A magyar telekommunikációs szektorban a verseny meglehetősen erős egy tulajdonképpen stagnáló piacon, ahol az értékesítés és bevétel növelésének szinte egyetlen lehetősége a jelenlegi portfólió teljes átalakítása. A telekommunikációs szolgáltatók nem képesek új megoldások bevezetésére, míg a kapacitásokat sok esetben elavult szolgáltatáscsomagok kötik le. Így a szolgáltatáskivezetésnek központi szerepe lehet a szolgáltatók új értékesítési céljainak elérésében.

Az esettanulmány elvégzése előtt egy szekunder kutatással a vizsgált telekommunikációs szolgáltató belső céginformációit vizsgáltuk, többek között a szolgáltatáskivezetési folyamatot bemutató dokumentumokat.

A kvalitatív kutatás primer elemzése mélyinterjús technikával történik félig strukturált kérdőívekkel. Választásunk azért esett erre a típusra, mert bizonyos kérdéseket szükségesnek érzünk feltenni a mechanizmusok feltárása érdekében, de fontos a kérdőív nyitottan tartása, az interjú során esetlegesen felmerülő új irányok érdekében, amelyeket részleteiben érdemes lehet elemezni.

Az esettanulmányt 2014 januárjában végeztük egy magyar telekommunikációs szolgáltatónál 3 menedzserekkel készült mélyinterjúval, akik részt vettek a vállalat egyik legnagyobb szolgáltatáskivezetési projektjében, 2012-2013-ban (a mélyinterjú guide az 1. függelékben található).

Az esettanulmány célja egy magyar telekommunikációs szolgáltató egyik legnagyobb szolgáltatáskivezetési projektjéről való információgyüjtés volt. Ahogyan a koncepcionális keretben vázoltuk, föként a szolgáltatáskivezetés okait és folyamatát szeretnénk feltárni (8. ábra).

A szolgáltatáskivezetés telekommunikációban való elemzéséhez kevés publikus forrás áll rendelkezésre, vagyis az interjúk számunkra az első lehetőséget biztosították arra, hogy információkat kapjunk a vállalat teljes szolgáltatáskivezetési folyamatáról.

Az első interjúalanyunk a magyar telekommunikációs szolgáltató Portfólió Menedzsere volt, aki rendszeres, új portfóliók indításával kapcsolatos vezetői megbeszéléseket szervezett. Az új szolgáltatásportfólió indítását egy összetett jóváhagyási folyamat előzi meg, amelynek döntési bizottsága igazgatókból áll, majd a folyamat végén a GMT (General Management Team, a vezérigazgató és vezérigazgató-helyettesek döntéshozó csoportja) hagyja jóvá vagy utasítja el a javaslatot.

Vagyis elsőként azt szerettük volna megismerni, hogy a szolgáltatáskivezetés esetében hasonló folyamat szükséges-e. Az derült ki, hogy a szolgáltatáskivezetés inkább ad-hoc 
alapon szerveződik és nincs hasonló menedzsment bizottság, amely döntene a kivezetendő szolgáltatások köréről:

"A szolgáltatáskivezetési döntést általában egy ember hozza meg."

“A tarifa [szolgáltatás] egyszerüsitési projektet fóként azért kellett elinditanunk, mert az offerek [a számlázási rendszerekben elérhető szolgáltatások] tesztelési és fenntartási költségei nagyon magasak, közel 2500 offerrel rendelkezünk jelenleg."

“Az ügyfél úgy dönthet, hogy felbontja a szerzödését, ha szolgáltatáskivezetést követöen tarifa [szolgáltatás] preferenciáiról kérdezzük.”

(Portfólió Menedzser, magyar telekommunikációs szolgáltató)

Néhány kutatási irányt is meghatározott számunkra: az ARPU (average revenue per user, egy ügyfélre eső bevétel) változás az eredeti szolgáltatás és a migráció utáni szolgáltatás között jelenleg nincs figyelembe véve a folyamatban; a lemorzsolódás nagyon magas, amely elfogadhatatlan szolgáltatáskivezetés esetén; a szolgáltatáskivezetési folyamat céljai nincsenek világosan meghatározva. Ezeket a javaslatokat beépítettük kvantitatív kutatásainkba.

A szolgáltatáskivezetés folyamatával kapcsolatban egy másik kérdés is felmerült: a jelenleg használt ügyfél számára ideális szolgáltatáskivezetés utáni szolgáltatást meghatározó modell sikerességi rátája mindössze $11 \%$ volt, amely azt jelenti, hogy 100 ügyfélből 11 választotta a modell által előrejelzett szolgáltatást.

A modell a projektben a következő függő változókat használta, amelyeket az általunk készített lemorzsolódást becslő modellben kiegészítettünk további magyarázó változókkal (4.4. fejezet): a szolgáltatás havidíja + a kiegészítő szolgáltatások havidíja - kedvezmények + (forgalom - forgalmi allowance [szolgáltatásban foglalt perc vagy adat] - szolgáltatás allowance) + fizetett mennyiségek.

Ahhoz, hogy az itt fennálló pontos problémát megérthessük, úgy döntöttünk, hogy egy második interjúalanyt is megkérdezünk az ügyfélérték menedzsment (customer value management, CVM) területről, a tervezési és kereskedelmi menedzserrel, aki a szolgáltatás migrációs modellt készítette a projekt során.

Ő is azt hangsúlyozta, hogy a szolgáltatáskivezetés fő okai a meglévő szolgáltatások számlázási rendszerben való magas költségei és fenntartási nehézségei voltak. A szolgáltatáskivezetés okait illetően nagyon egyértelmü válaszokat adott, az előző interjúalanyunkhoz hasonlóan: 
"A tarifa [szolgáltatás] szimulációs modell az összes elérhető tarifa árazását az ügyfelek hívási szokásai alapján végezte.”

“A 11\%-os sikerességi ráta a szolgáltatáskivezetési folyamat során tapasztalt alacsony válaszadási ráták eredménye volt: a telesales nagyjából az ügyfelek 60\%-át tudja elérni, ahol a válaszadási arány meglepöen magas volt, 20-30\%. A többi ügyfelet DM levélben értesítettük, ahol már csak 2\%-os sikerességi rátát tudtunk elérni."

“A kivezetett tarifa [szolgáltatás] általában nagyon régi, vagyis már nem füzödik üzleti érdek a megtartásához; vagy nagyon kevés elöfizetö használja a szolgáltatást; vagy a tarifa profitabilitási számitások szerint a szolgáltatás profit rátája nagyon alacsony; vagy a legtöbb esetben a szolgáltatáskivezetés oka egy új portfólió bevezetése."

(CVM Tervezési és Kereskedelmi Menedzser, magyar telekommunikációs szolgáltató)

Ezeken kívül azt is kiemelte, hogy az ügyfeleket szegmentálni kell, mert az életciklusuk alapján teljesen eltérö eszközökre lehet szükség szolgáltatáskivezetés esetén: a legveszélyesebbnek tartott szegmens ilyen értelemben a szolgáltatóval 2 évnél hosszabb ideje szerződéses kapcsolatban álló ügyfelek, mivel a kivezetett szolgáltatás nem kényszeríti őket kötbér fizetésére. Vagyis az úgynevezett out-of-contract ügyfelek, akiknél a kötelezően vállalat szerződéses időtartam már lejárt (ez Magyarországon rendszerint 2 év, de más országokban lehet 1 év vagy hüségidő nélküli is), nagyobb valószínüséggel hagyják el a vállalatot szolgáltatáskivezetés esetén. Ennek további becslésére a szerződés időtartamát és a váltási korlátokat használjuk a 3. tanulmányban.

A kvantitatív modell jobb megértésében is segített minket: a 11\%-os sikerességi ráta nem a modellezési problémák eredménye (5\%-os konfidenciaintervallum figyelembevételével), amelyet a modell használt a legmegfelelőbb szolgáltatás becslésére, hanem az ügyfél döntött úgy, hogy elhagyja a vállalatot. Ez számunkra fontos javaslatot jelentett az ügyféloldal további vizsgálatával kapcsolatban (1. és 2. tanulmány), a lemorzsolódási modell elemzése mellett.

A folyamattal kapcsolatos további kérdések fontos problémákat tártak fel: sok ügyfelet a szolgáltató nem tudott elérni. Öket kényszermigrációval irányították át az úgynevezett alap szolgáltatásra (amelynek a feltételei azonban nagyon kedvezőtlenek, elsősorban a magas percdíjak és magas havidíj miatt), ahol a lemorzsolódási ráta már 20-30\% között volt. Ez felhívja a figyelmet a szolgáltatáskivezetés esetén fellépő lemorzsolódás csökkentésének szükségességére. 
A folyamat különböző problémáinak mélyebb megértése érdekében megszerveztük a harmadik interjút a vállalat CVM SOHO (small office-home office) menedzserével. A folyamat olyan részleteiről beszélt, amely rávilágított a magas lemorzsolódás okaira:

„Az ügyfél elöször egy levél értesitést kap, 60 nappal a kivezetés elött. Ha az ügyfél erre nem válaszol, akkor 60 nap elteltével automatikusan átkerül az alaptarifára. Ez nagy számú panaszt eredményez, mert azt is igazolnunk kell ezekben az esetekben, hogy az értesitést legalább kétszer megkapták, vagy az ajánlott tarifa [szolgáltatás] nem volt megfelelö.",

(CVM-SOHO Menedzser, magyar telekommunikációs szolgáltató)

A beszélgetésböl egyértelmüen kiderült számunkra, hogy az ügyfél nagyon frusztrált a szolgáltatáskivezetés teljes folyamata során. A postai úton történő értesítés valószínủleg az érintett ügyfelek értesítésének nem a legjobb módja, mert a problémát valójában csak a kényszermigráció után érzékelik (azáltal, hogy jelentősen nagyobb összegü számlát kapnak), amely azonnali lemorzsolódáshoz vezet. Ez azt jelenti, hogy a folyamat során használt kommunikációs eszközöket is mérlegelni kell. Ezt használjuk interakciós intenzitásként a 3. tanulmányban. Továbbá, a szolgáltatáskivezetést ügyfélmegtartási stratégiaként kellene kezelni, nem pedig egy normál életciklus szakaszában bekövetkező eseménynek.

A 2014 januárjában egy magyar telekommunikációs szolgáltatónál végzett esettanulmány során sikerült néhány kritikus pontot azonosítanunk a folyamat során, amelyek megalapozták a 3. tanulmánnyal kapcsolatos hipotéziseinket. Elsőként azt emelnénk ki, hogy a telesales által történő hívás a CVM-alapú folyamat nem kötelező eleme, lehetőség van eDM (elektronikus direkt marketing levél) kiküldésére is, amely növeli az ügyfél pszichológiai költségeit (az 1. tanulmányban késői értesítésként operacionalizált változó) (9. ábra). Ez a levél növeli az ügyfél bizonytalanságát, és emellett kényszermigrációra is lehetőség van, amely rendszerint kedvezőtlen az ügyfél számára. A gyakorlatban az ügyfeleket sokkolja az ilyen kényszermigráció esetén kapott első számla, és a jelenlegi szolgáltatáshoz képest rendszerint kedvezötlenebb feltételek miatt az ügyfelek azonnal megszüntetik az előfizetésüket. Ezt a folyamatot tehát a lemorzsolódást növelő tényezőként azonosítjuk.

A mélyinterjúk során tapasztalt ellentmondásokat jól szemlélteti a 9. ábrán látható folyamatábra. A folyamat egy kockázatos elemet is tartalmaz: ha az ügyfelet e-DM útján értesítik, és nem hajlandó egy másik szolgáltatást választani, akkor az ügyfelet kényszermigrációval az alapszolgáltatásra irányítják át, amely a legtöbb esetben az ügyfél 
számára az egyik legkedvezőtlenebb megoldás, a fellépő gazdasági és pszichológiai költségek miatt. Ennek eredményeképpen a kényszermigráció növeli az ilyen esetekben jelentkező lemorzsolódást.

\section{9. ábra: A szolgáltatáskivezetés folyamata}

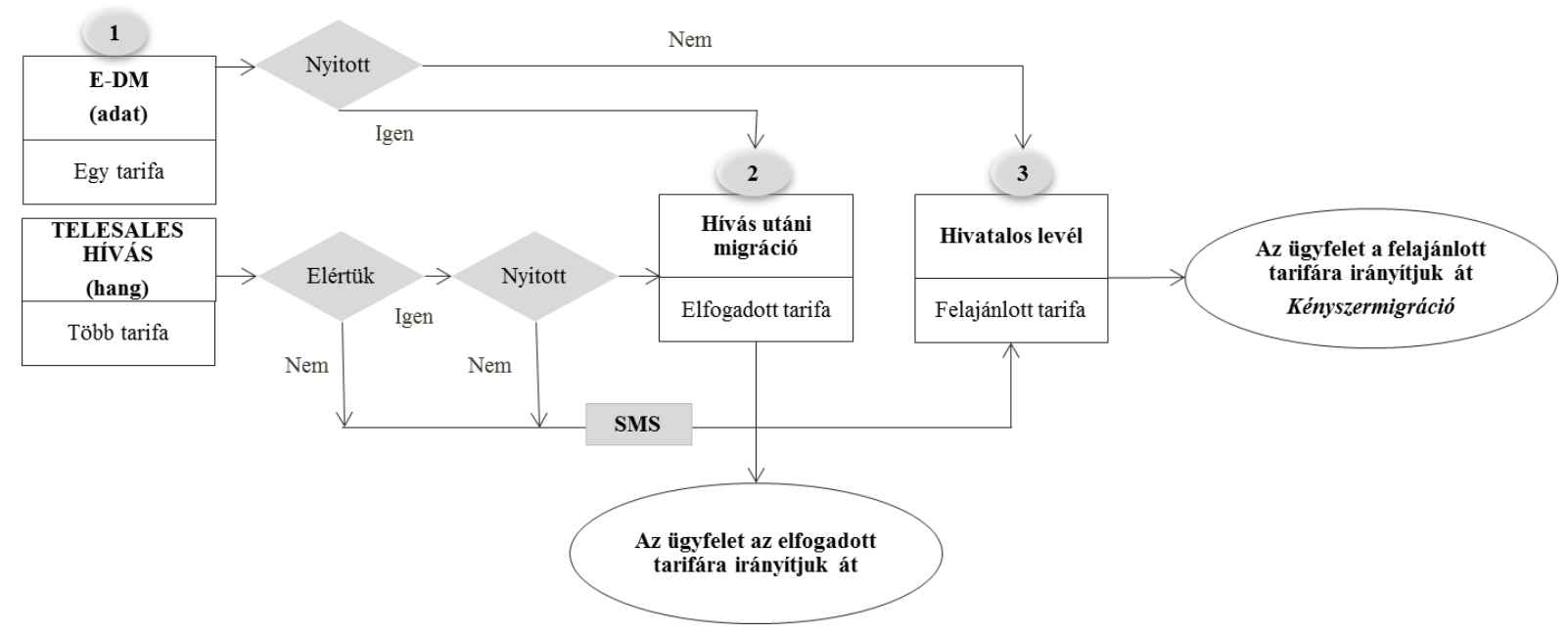

Forrás: Magyar telekommunikációs szolgáltató, 2013

Az esettanulmány eredményei alapján a következő hipotézist fogalmazzuk meg:

A szolgáltatáskivezetés esetén jelentkező lemorzsolódás magasabb a normál lemorzsolódáshoz képest.

Az esettanulmány bemutatta, hogy gyakorlati oldalról szükséges az ügyfél lemorzsolódás csökkentése szolgáltatáskivezetés esetén, amelyhez a szolgáltatáskivezetési folyamatok ügyfél igényekhez való igazítása, és a kivezetést követő javasolt új szolgáltatást meghatározó modell továbbfejlesztése egyaránt szükséges.

Vagyis az esettanulmány három fö tanulsággal járt:

- A szolgáltatáskivezetés sikertényezőinek vizsgálata releváns gyakorlati szempontból;

- A sikertényezőkön belül, gyakorlati oldalról szükség van egy jobb modell meghatározására, amely az ügyfél szolgáltatáskivezetés utáni szolgáltatáscsomagját számítja ki, alacsonyabb lemorzsolódást eredményezve;

- A szolgáltatáskivezetési folyamatnak az ügyfél igényeihez jobban kell igazodnia és az ügyfélmegtartás részeként kell kezelni ahhoz, hogy a folyamat során fellépő lemorzsolódást csökkenteni lehessen.

Ahogyan az esettanulmány is rávilágított, a téma releváns további elemzés céljából, különösképpen az ügyfélmegtartás és lemorzsolódás szempontjából. Az 1-3. tanulmányokat ezek alapján terveztük meg. 
Az esettanulmány limitált olyan szempontból, hogy kizárólag három mélyinterjúból áll, egy magyar telekommunikációs szolgáltatót elemezve, amely kibővíthető lenne más szolgáltatóktól gyüjtött további eredményekkel. Ennek ellenére sikerült megértenünk a szolgáltatáskivezetés okait és folyamatának főbb jellemzőit, amely megalapozta további kutatásainkat.

\subsection{KUTATÁSI KÉRDÉSEK ÉS HIPOTÉZISEK}

A szakirodalmi áttekintés és az esettanulmány alapján a következő kutatási kérdéseket fogalmaztuk meg:

1. Hogyan használható a társadalmi csere elmélete a szolgáltatáskivezetést követő ügyfélreakció (lemorzsolódás, elégedettség, lojalitás, affektív és kalkulatív elkötelezettség, WOM) magyarázatára?

2. Hogyan használható az igazságosság elmélet a szolgáltatáskivezetést követő ügyfélreakció (lemorzsolódás, elégedettség, lojalitás, affektív és kalkulatív elkötelezettség, WOM) magyarázatára?

3. Magasabb a lemorzsolódás a normál lemorzsolódáshoz képest szolgáltatáskivezetés esetén?

4. A szolgáltatáskivezetés utáni lemorzsolódást hogyan befolyásolják a szolgáltatáskivezetés és az ügyfél tulajdonságai?

5. A szolgáltatáskivezetést követő használat intenzitását hogyan befolyásolják a szolgáltatáskivezetés és az ügyfél tulajdonságai?

Mivel a kutatási kérdések különböző módszertant igényelnek, kutatásunkat ennek megfelelően terveztük meg:

- 1-2. kutatási kérdés: kvantitatív módszertan- forgatókönyvön alapuló kísérleti módszertan fogyasztói kérdöívvel (1. és 2. tanulmány);

- 3-5. kutatási kérdés: kvantitatív módszertan- adatbázis elemzés Heckman- féle korrekciós eljárással (3. tanulmány).

A szakirodalmi áttekintés és a koncepcionális keret alapján három tanulmányt készítettünk elő a kutatási kérdések megválaszolása és a hipotézisek tesztelése érdekében, amelyeket részletesen a következő alfejezetekben mutatunk be. 


\subsubsection{TANULMÁNY: KÍSÉRLETI MÓDSZERTAN: A SZOLGÁLTATÁSKIVEZETÉS KIMENETELÉT}

MEGHATÁROZÓ SZOLGÁLTATÁSKIVEZETÉSI ÜGYFÉLREAKCIÓK A TÁRSADALMI CSERE ELMÉLET ALAPJÁN

$\mathrm{Az}$ 1. tanulmány célja a szolgáltatáskivezetést követő ügyfélreakciók jobb megértése telekommunikációs kontextusban a társadalmi csere elméletén keresztül, a szolgáltatáskivezetés ügyfelekre gyakorolt hatásának elemzése érdekében.

Mivel a szakirodalom tudomásunk szerint még nem kapcsolta össze a társadalmi csere elméletet a szolgáltatáskivezetés kimenetének ügyfél szempontú elemzésével, ez a tanulmány hozzájárulhat ezen szakirodalmi rés empirikus eredményeinek gazdagításához. A függő változózók széles skáláját használjuk az ügyfélreakciók számos aspektusának feltárásához.

\section{Az 1. tanulmányban az 1. kutatási kérdésre fókuszálunk:}

1. Hogyan használható a társadalmi csere elmélet a szolgáltatáskivezetést követő ügyfélreakció (lemorzsolódás, elégedettség, lojalitás, affektív és kalkulatív elkötelezettség, WOM) magyarázatára?

A szolgáltatáskivezetés gazdasági költségei a szolgáltatáskivezetés során az ügyfél számára felmerülő pénzügyi veszteséget vagy kiadást fejezik ki (Homburg et al., 2010). A megnövekedett pénzügyi terhek miatt, az ügyfél kevésbé elégedett a szolgáltatóval és már kevésbé találja kedvezőnek a vállalattal való kapcsolat fenntartását, vagyis nagyobb valószínűséggel hagyja el a vállalatot.

A gazdasági költség, ügyfélmegtartás, elégedettség és elkötelezettség szakirodalma alapján a következőt várjuk:

1. Hipotézis: A gazdasági költség növeli a lemorzsolódást, és WOM-ot, és csökkenti az elégedettséget, lojalitást, affektív és kalkulativ elkötelezettséget szolgáltatáskivezetés esetén.

A pszichológiai költség a vállalat szolgáltatáskivezetés során tapasztalt megbízhatóságát, rugalmasságát és együttmüködési hajlandóságát (Foa \& Foa, 1974; Foa \& Foa, 1980), valamint az ügyfél szolgáltatáskivezetést végző vállalattal szembeni elbizonytalanodásának mértékét, és a vállalattal való kapcsolat fenntartásának kétségbevonását fejezi ki (Homburg et al., 2010). A pszichológiai költségek bármely kellemetlen belső állapotra utalhatnak, amelyek végül a bizalom csökkenését eredményezik. Vagyis a pszichológiai költségek várhatóan 
növelik az ügyfél lemorzsolódás iránti szándékát, és csökkentik az elégedettséget, lojalitást és elkötelezettséget.

A pszichológiai költség, ügyfélmegtartás, elégedettség és elkötelezettség szakirodalma alapján a következőt várjuk:

2. hipotézis: A pszichológiai költség növeli a lemorzsolódást, és WOM-ot, és csökkenti az elégedettséget, lojalitást, affektív és kalkulatív elkötelezettséget szolgáltatáskivezetés esetén.

A gazdasági költség ügyfélpercepciója a pszichológiai költségeken keresztül módosítható. A szolgáltató módosíthatja a „hard faktorokat” a megfelelő „soft faktorok” használatával (Foa \& Foa, 1974; Foa \& Foa, 1980), a pszichológiai költségek csökkentésével.

A gazdasági és pszichológiai költségek között fellépő interakciók magyarázatához az ismeret (kognitív megközelítés) és érzelem (affektív megközelítés) koncepcióit használjuk, amelyek számos szolgáltatáskutatás témái (pl. Oliver, 1980; LaBarbera \& Mazursky, 1983; Oliver \& DeSarbo, 1988; Westbrook \& Oliver, 1991; Mano \& Oliver, 1993).

Kempf (1999) arra mutatott rá, hogy a funkcionális termékeknél az ismeretek sokkal fontosabbak a termék értékelések szempontjából, mint az érzelmek, a hedonikus termékekkel összehasonlítva. A telekommunikáció funkcionális szolgáltatásnak tekinthető, emellett azt feltételezzük, hogy a gazdasági költségek a kognitív megközelítést, míg a pszichológiai költségek az affektív megközelítést képviselik. Amikor gazdasági költségek is jelen vannak, az ismeretek dominánsabbak az érzelmeknél, míg a gazdasági költségek hiányában az érzelmeknek a hatása erősebb lehet.

Ezek alapján a következőt várjuk:

3. Hipotézis: A gazdasági és pszichológiai költségek között interakciós hatás figyelhetö meg szolgáltatáskivezetés esetén.

\subsubsection{TANULMÁNY: KÍSÉRLETI MÓDSZERTAN: A SZOLGÁLTATÁSKIVEZETÉS KIMENETELÉT} MEGHATÁROZÓ SZOLGÁLTATÁSKIVEZETÉSI ÜGYFÉLREAKCIÓK AZ IGAZSÁGOSSÁG ELMÉLET ALAPJÁN

A 2. tanulmányban az igazságosság elméletet használjuk a szolgáltatáskivezetést követő ügyfélreakció és a folyamat ügyfelekre gyakorolt hatásának jobb megértése érdekében telekommunikációs kontextusban.

Az igazságosság elmélet empirikus eredményeinek gazdagításához is hozzájárulhat kutatásunk, mivel az elméletet tudomásunk szerint még ilyen kontextusban nem vizsgálták. 
$\mathrm{Az}$ 1. tanulmány eredményei alapján a lemorzsolódást, elégedettséget és lojalitást használjuk az ügyfélreakciók fö aspektusainak feltárásához, hiszen ez jellemzi leginkább a szolgáltatáskivezetés kimenetelét. Az 1. tanulmányban használt további változók nem kapcsolódnak szorosan a témához (mint például az elkötelezettség különböző dimenziói).

\section{A 2. tanulmányban a 2. kutatási kérdésre fókuszálunk:}

2. Hogyan használható az igazságosság elmélet a szolgáltatáskivezetést követő ügyfélreakció (lemorzsolódás, elégedettség, lojalitás, affektív és kalkulatív elkötelezettség, WOM) magyarázatára?

Az igazságosság három dimenzióját használjuk (Clemmer \& Schneider, 1996): a disztibutív igazságosság a szolgáltatáskivezetés kimenetének tapasztalt igazságosságát, a procedurális igazságosság a szolgáltatáskivezetés kimenetének előállításához kötődő irányelvek és folyamatok igazságosságát, az interakciós igazságosság pedig a szolgáltatáskivezetési folyamat során tapasztalt személyes bánásmódot fejezi ki.

Az igazságosság koncepcióját számos területen használták, többek között béremelés (Folger \& Konovsky, 1989), munkaviszony (Greenberg, 1990), jogi vonatkozások (Thibaut \& Walker, 1975), és eladói/vevői kapcsolatok (Clemmer, 1993; Oliver \& Swan, 1989) esetében. Az utóbbi áll legközelebb a szolgáltatáskivezetéshez, azonban közös bennük, hogy az igazságosságnak pszichológiai (mint például az elégedettség és lojalitás) és viselkedési kimenete (újravásárlási szándék, amely szolgáltatáskivezetés esetén ügyfélmegtartásként értelmezhető) egyaránt van. Ezeket a koncepciókat az ügyfélreakciók részeként használjuk.

A disztributív igazságosság a társadalmi csere elméletben gyökerezik (Blau, 1964), és nem más, mint az eredmény tapasztalt igazságossága két vagy több fél között történő diskurzus, tárgyalás vagy döntés során (Blodgett et al., 1997). A szolgáltatásmarketing szakirodalom alapján a disztributív igazságossággal összefüggő értékelések befolyásolják az ügyfélelégedettséget, tapasztalt szolgáltatásminőséget és újravásárlási szándékot (Fisk \& Coney, 1982; Mowen \& Grove, 1983; Oliver \& DeSarbo, 1988; Oliver \& Swan, 1989; Huppertz et al., 1978).

Habár a tapasztalt igazságosságot a szolgáltatáskivezetéssel tudomásunk szerint még nem kapcsolták össze, szolgáltatási hibaként történő értelmezése során a tapasztalt igazságosság befolyásolja az ügyfél viselkedési szándékát (Blodgett et al., 1997). A lojalitás az ügyfél az elektronikus vagy mobil értékesítő felé tanúsított kedvező attitűdje, amelynek 
eredménye az ismételt vásárlási magatartás (Srinivasan et al., 2002; Lin \& Wang, 2006). A lojalitás szempontjából, a tapasztalt igazságosság pozitívan befolyásolja az ügyfél újralátogatási szándékát (Ha \& Jang, 2009).

A disztributív igazságosság, ügyfélmegtartás, elégedettség és lojalitás szakirodalma alapján a következőt várjuk:

4. Hipotézis: A disztributív igazságosság csökkenti a lemorzsolódást, és növeli az elégedettséget és lojalitást szolgáltatáskivezetés esetén.

A procedurális igazságosság az irányelvek, folyamatok és kimenetelhez vezető kritériumok tapasztalt igazságosságát fejezi ki (Thibaut \& Walker, 1975; Lind \& Tyler, 1988; Alexander \& Ruderman, 1987). A procedurális igazságosság központi kérdése a sebesség (Clemmer \& Schneider, 1996; Hart et al., 1990; Kelley et al., 1990), amely a panaszkezelési folyamat időszerüségét, reakcióképességét és kényelmességét fejezi ki (Blodgett et al., 1997). A szolgáltatási helyzetekben tapasztalt igazságtalanság vagy hosszú várakozási idő negatív érzelmi állapothoz és elégedetlenséghez vezet (Katz et al., 1991; Venkatesan \& Anderson, 1985).

Az igazságosság dimenzióinak (disztributív, procedurális és interakciós) közvetlen hatásuk van az ügyfélmegtartásra (Blodgett \& Tax, 1993; McCollough et al., 2000). Az igazságosság (disztributív, interakciós és részben a procedurális igazságosság) a kilépési lojalitást az érzelmeken keresztül befolyásolja (Chebat \& Slusarczyk, 2005).

A procedurális igazságosság, ügyfélmegtartás, elégedettség és lojalitás szakirodalma alapján a következőt várjuk:

5. Hipotézis: A procedurális igazságosság csökkenti a lemorzsolódást, és növeli az elégedettséget és lojalitást szolgáltatáskivezetés esetén.

Az interakciós igazságosság azt fejezi ki, hogy az emberek bizonyos bánásmódban részesülnek a folyamat során, mint például az udvariasság, tisztelet, vagy a gorombaság (Bies \& Moag, 1986; Bies \& Shapiro, 1987).

Az igazságosság három formája közül az interakciós igazságosság az ügyfélmegtartás legfontosabb elörejelzője (Chebat \& Slusarczyk, 2005; Wang et al., 2011) úgy, hogy az interakciós igazságosság a kilépési lojalitást közvetlenül és közvetett módon egyaránt az érzelmeken keresztül befolyásolja. A procedurális és interakciós igazságosság egyaránt 
pozitív hatással van a lojalitásra, és a magasabb szintü interakciós igazságosság gyengíti a kapcsolatot a szolgáltatási hiba és lojalitás között (Wang et al., 2011).

Marketing kontextusban az interakciós igazságosság hozzájárul a szolgáltatás igénybevételével való elégedettséghez (Bitner et al., 1990; Tyler, 1987), a szolgáltatásminőség jobb értékeléséhez (Parasuraman et al., 1985) és az újravásárlási szándékhoz (Blodgett \& Tax, 1993).

Az interakciós igazságosság, ügyfélmegtartás, elégedettség és lojalitás szakirodalma alapján a következőt várjuk:

6. Hipotézis: Az interakciós igazságosság csökkenti a lemorzsolódást, és növeli az elégedettséget és lojalitást szolgáltatáskivezetés esetén.

Az igazságosság három elemének kombinációja határozza meg az ügyfél átfogó értékelését az igazságossággal kapcsolatban. A három elem irányát tekintve a szakirodalom különböző álláspontokat képvisel. Az interakciós igazságosság képes a disztibutív igazságosság bizonyos alacsonyabb szintjét kiegyenlíteni, és a procedurális igazságosság magasabb szintje képes a disztributív igazságosság alacsonyabb szintjét kompenzálni (Blodgett et al., 1997). Továbbá, az interakciós és procedurális igazságosság kiegészítő jellegü: a procedurális igazságossággal kapcsolatos ítéletet befolyásolja az irányelvek helyessége és a folyamat során tapasztalt bánásmód (Bies \& Moag, 1986; Tyler \& Bies, 1989).

Ezért a következőket várjuk:

7. Hipotézis: A disztributív, procedurális és interakciós igazságosság között interakciós hatás figyelhető meg szolgáltatáskivezetés esetén.

\subsubsection{TANULMÁNY: ADATBÁZIS ELEMZÉS: AZ ÜGYFÉL ÉS SZOLGÁLTATÁSKIVEZETÉS TULAJDONSÁGAINAK SZOLGÁLTATÁSKIVEZETÉS KIMENETÉRE ÉS SZOLGÁLTATÁSKIVEZETÉST KÖVETÖ HASZNÁLAT INTENZITÁSÁRA GYAKOROLT HATÁSA}

Az adatbázis elemzés a szolgáltatáskivezetés következményeire összpontosít: a szolgáltatáskivezetés sikertényezői és az ügyfélreakciók közötti kapcsolatra, amely során a lemorzsolódás kulcskérdésnek tekinthető.

Az adatbázis elemzés fő célja a lemorzsolódás, a szolgáltatás elemei és az ügyfél tulajdonságai közötti kapcsolat feltárása. A szakirodalmi áttekintés a lemorzsolódás csökkentési stratégiákra hívja fel a figyelmet, és a lemorzsolódás használata, amely egy 
Dummy változó, kizárólag néhány marketingkutatási és ökonometriai módszertan alkalmazását teszi lehetővé.

\section{A 3. tanulmányban a 3-5. kutatási kérdésekre fókuszálunk:}

3. Szolgáltatáskivezetés esetén magasabb a lemorzsolódás a normál lemorzsolódáshoz képest?

4. A szolgáltatáskivezetés utáni lemorzsolódást hogyan befolyásolják a szolgáltatáskivezetés és az ügyfél tulajdonságai?

5. A szolgáltatáskivezetést követő használat intenzitását hogyan befolyásolják a szolgáltatáskivezetés és az ügyfél tulajdonságai?

Az esettanulmány eredményei alapján a következő hipotézist fogalmazzuk meg:

8. Hipotézis: A szolgáltatáskivezetés esetén jelentkezö lemorzsolódás magasabb a normál lemorzsolódáshoz képest.

Az ügyfélmegtartás definíció szerint ,annak a valószinüsége, hogy az ügyfél a szolgáltatónál marad a jövőben” (Ranaweera \& Prabhu, 2003, 381. o.). Az ügyfélmegtartás két formája a termék-specifikus megtartási ráta és a tágabban értelmezett megtartási ráta. Kutatásunkban a megtartást tágabb értelemben használjuk, hiszen mivel a szolgáltatás megszünik, a szolgáltatás-specifikus megközelítés esetünkben nem releváns. Ezért a lemorzsolódást úgy definiáljuk, hogy az ügyfél elhagyja a vállalatot szolgáltatáskivezetést követően. A szolgáltatáskivezetés esetén fellépő magas lemorzsolódás miatt a megtartás a folyamat sikerességének egyik legfontosabb indikátora lehet, amelyet kutatásunkban is használunk.

Az ügyfél szerződésének státusza kapcsolatban áll az ügyfélmegtartással (Lam et al., 2004): a szerződés lejárata előtt a váltási költségek jelentősen magasabbak, amely ezáltal váltási korlátként is értelmezhető, amely megakadályozza a lemorzsolódást és a szolgáltatáskivezetés sikerességére is hatással van, annak időzítését és érintett szolgáltatásait tekintve.

A szerződés időtartama (tenure) az ügyfél szolgáltatóval való szerződésének kezdete és lemorzsolódása között eltelt idő (Allison, 1995), vagyis kifejezi, hogy milyen régóra áll szerződéses kapcsolatban az ügyfél a vállalattal. A váltási korlátok minden olyan tényezőt magukba foglalnak, amelyek az ügyfél számára összességében költségesebbé teszik a 
szolgáltatóváltást, és ezáltal jelentősen befolyásolják a lojalitást (Colgate \& Lang, 2001; Jones et al., 2002; Lee \& Cunningham, 2001). Az interakciós intenzitás pedig esetünkben a szolgáltatóvállalat és ügyfél között történő interakciók számát jelenti (mind az ügyfél, mind pedig a szolgáltató által kezdeményezett esetben) a szerződés teljes időtartama alatt (Czepiel \& Gilmore, 1987).

„A szolgáltatáslojalitás az ügyfél szolgáltatótól való ismételt vásárlási magatartási szándékának mértéke, amely során a szolgáltató iránt pozitív attitüddel rendelkezik és ezt az egyetlen szolgáltatót veszi számításba, amennyiben a szolgáltatással kapcsolatos igénye felmerül” (Gremler \& Brown, 1996, 173. o.). A lojalitás két fő definíciója közül- attitüd (Fournier, 2003) és viselkedési (Kenningham et al., 2007) lojalitás-, kutatásunk során a viselkedési lojalitást használjuk, mivel ez fejezi ki mérhető módon a lemorzsolódást, amely közvetlenül kapcsolódik az ügyfélmegtartáshoz.

A szolgáltatóvállalatok rendszerint az új ügyfelek számára kedvezményeket nyújtanak, amelyek gyakran nem elérhetőek a meglévő ügyfelek számára. Ez azt eredményezheti, hogy a racionális ügyfelek az alacsony árat kizárólag átmenetinek ítélik meg, amely az új ügyfelek számára mindig akkor lesz a legelőnyösebb, ha a legalacsonyabb árú szolgáltatót választják. Másfelől ez azt is jelenti, hogy a szerződés lejárta előtt lévő ügyfelek rendszerint magasabb árakkal szembesülnek. Vagyis a váltási magatartást az ügyfél jövőbeli árszintekre vonatkozó elvárásai határozzák meg (McSorley et al., 2003).

Az ügyfélmegtartás és áremelkedés szakirodalma alapján a következőt várjuk:

9. Hipotézis: Az áremelkedés csökkenti az ügyfélmegtartás valószinüségét szolgáltatáskivezetés esetén, árcsökkenéssel összehasonlítva.

Hipotézisünk alapján tehát az áremelkedésnek hatása van az ügyfélmegtartásra, az ügyfelek nagyobb valószínűséggel hagyják el a vállalatot. Bolton és Lemon (1999) arra hívják fel a figyelmet, hogy a rezervációs ár kulcsfontosságú a váltási magatartás során. Ha az új ár alacsonyabb a rezervációs árnál, akkor az ügyfél növelheti használatának mértékét, a magasabb rezervációs ár viszont a lemorzsolódás valószínűségét növeli.

A vállalatnál maradó ügyfelek közül azok növelik használatuk mértékét, akik áremelkedést tapasztaltak, mivel az áremelkedést magasabb szintű használattal kívánják kompenzálni, ehhez képest az árcsökkenés pedig csökkenti az ügyfelek használatának mértékét (Bolton \& Lemon, 1999). Szolgáltatáskivezetés esetén hasonló hatást várunk, ahol 
az új ár a szolgáltatáskivezetés utáni szolgáltatás árát, a régi ár pedig a kivezetett szolgáltatás árát jelenti.

A használat intenzitása és áremelkedés szakirodalma alapján a következőt várjuk:

10. Hipotézis: Az áremelkedés növeli a szolgáltatáskivezetést követö használat mértékét árcsökkenéssel összehasonlitva.

A hosszabb kapcsolat hozzájárul az ügyfélmegtartáshoz (Dagger, et al., 2009). Dawes (2009) eredményei szerint a szerződés hosszabb időtartama csökkenti a lemorzsolódás valószínűségét. Ö a lemorzsolódást termék-specifikus ügyfélmegtartásként definiálta, a hatás további elemzése szükséges annak eldöntésére, hogy az eredmény a tágabb értelemben vett ügyfélmegtartásra is érvényes-e, illetve szolgáltatáskivezetés esetében. Habár a szolgáltatáskivezetésre vonatkozóan a szakirodalom tudomásunk szerint nem közöl eredményt (Avlonitis \& Argouslidis, 2012).

Az ügyfélmegtartás és a szerződés időtartama szakirodalma alapján a következőt várjuk:

11. Hipotézis: A hosszabb szerzödéses kapcsolat a szolgáltatóval növeli az ügyfélmegtartás valószinüségét szolgáltatáskivezetés esetén, a rövidebb szerzödéses kapcsolattal összehasonlitva.

A váltási költségek és ügyfélmegtartás közötti kapcsolat szakirodalma jól megalapozott (Bansal \& Taylor, 1999; Gremler \& Brown, 1996; Lee et al., 2001). Burnham és szerzőtársai (2003) azt találták, hogy az ügyfél szolgáltatóval való kapcsolatának fenntartási szándékát a váltási költségek 30\%-ban magyarázzák. A szerzödéses váltási költségek és a lojalitás között szintén van kapcsolat (Caruana, 2004).

A váltási költségek tipológiáját tekintve Klemperer (1987) megközelítését követjük, aki a tranzakciós költségeket, tanulási költségeket és mesterséges vagy más néven szerződéses költségeket azonosítja. Kutatásunkban a szerződéses költségekre összpontosítunk, amelyek az előny elvesztésének költségének (benefit loss cost) részét képezik (Burnham et al., 2003).

A szerződéses költség minden szerződéses kapcsolathoz köthető költséget magában foglal, amely az adott vállalattal való kapcsolat fenntartásából származó gazdasági előnyeit hozza létre (Guiltinan, 1989) az ügyfél bizonyos időtartamra szóló lojalitásának biztosítására (Caruana, 2004). Az ügyfelek kötbér fizetésére jogosultak, amennyiben a vállalt idő előtt elhagyják a vállalatot. Vagyis a szerződés lejárata növeli a lemorzsolódás kockázatát. 
Mivel a szolgáltatáskivezetés gyakran jár kényszermigrációval, amely azt jelenti, hogy az ügyfelek automatikusan egy új szolgáltatásra kerülnek át a jelenlegi szolgáltatás kivezetését követően, ez a váltás sokkal gyakoribb is lehet. A szakirodalom azonban nem fogalmaz meg arra vonatkozóan ajánlást, hogy a szolgáltatáskivezetés esetén fellépő lemorzsolódást hogyan lehetne csökkenteni a váltási korlátokkal, csak általános ügyfélmegtartási helyzetekre vonatkozóan találhatóak ilyen eredmények (Lam et al., 2004).

Az ügyfélmegtartás és váltási korlátok szakirodalma alapján a következöt várjuk:

12. Hipotézis: A váltási korlátok növelik az ügyfélmegtartás valószínüségét szolgáltatáskivezetés esetén, a váltási korlátok hiányával összehasonlitva.

$\mathrm{Az}$ interakciós intenzitás a szolgáltatások egyik kiemelt tulajdonsága. A szolgáltatóvállalat és az ügyfél közti interakció jelentősen befolyásolja a minőséggel, elégedettséggel és újravásárlással kapcsolatos percepciókat (Bateson, 1985; Cermak et al.,1991; Jeanne Hill, 1988; Kelley et al., 1990; Mills \& Morris, 1986), vagyis hatással lehet az ügyfélmegtartásra egyaránt.

Mivel a különböző szituációk függvényében változhatnak az ügyfelek interakciós intenzitással kapcsolatos elvárásai (Berthon \& John, 2014), a szolgáltatáskivezetés előtti interakció fontos stratégiának tekinthető az ügyfelek elvárásai alapján. A szolgáltatóvállalattal kiépített intenzívebb kapcsolat egyaránt lehet pozitív vagy negatív hatással az ügyfélre. A fogyasztói magatartás és elvárások változásával, a túlságosan gyakori személyes kapcsolat a szolgáltató szándékával ellentétes hatást is kiválthat. Ezért lényeges az interakció optimális szintjének meghatározása, amely ideális esetben hozzájárul a bizalom kialakításához és növeli a lojalitást.

Az ügyfélmegtartás és az interakciós intenzitás szakirodalma alapján a következőt várjuk:

13. Hipotézis: Az interakciós intenzitás magasabb szintje növeli az ügyfélmegtartást szolgáltatáskivezetés esetén, az interakciós intenzitás alacsonyabb szintjével összehasonlitva.

Ahogyan már megjegyeztük, a szolgáltatáskivezetés közvetlen interakciót igényel az ügyfél és a szolgáltatóvállalat között a lemorzsolódás csökkentése érdekében. Pfisterer és Roth (2015) szerint az ügyfelek megkülönböztetik a közvetlen és közvetett interakciót igényelő felhasználói folyamatokat. Ilyen tekintetben, a szolgáltatáskivezetés közvetlen kommunikációt igényel, egyrészt az életciklus vége (a szolgáltatás eléri az életgörbéje 
csökkenő szakaszát és megszünik), másrészt pedig a szolgáltatáskivezetés sajátosságai miatt. A közvetlen és intenzívebb interakció az életciklus más szakaszaival összehasonlítva figyelemfelkeltő hatással is bírhat a tarifacsomag elemeire vonatkozóan, és befolyásolhatja az ügyfél szolgáltatáskivezetést követő használatát, amennyiben a vállalatnál marad. Habár amennyiben az ügyfél úgy dönt, hogy a vállalatnál marad, a használatának intenzitása alacsonyabb is lehet, a szolgáltatáskivezetés utáni tudatosabb használat kialakulása miatt. A szakirodalom állásfoglalása etekintetben nem egyértelmü.

A használat intenzitása és az interakciós intenzitás szakirodalma alapján a következőt várjuk:

14. Hipotézis: Az interakciós intenzitás magasabb szintje növeli a szolglátatáskivezetést követö alacsonyabb használat valószinüségét, az interakciós intenzitás alacsonyabb szintjével összehasonlitva.

\subsection{A KUTATÁSI HIPOTÉZISEK ÖSSZEFOGLALÁSA}

A koncepcionális keret a kutatási hipotézisekkel kiegészítve a 10. ábrán látható:

\section{0. ábra: A szolgáltatáskivezetés koncepcionális kerete hipotézisekkel kiegészítve}

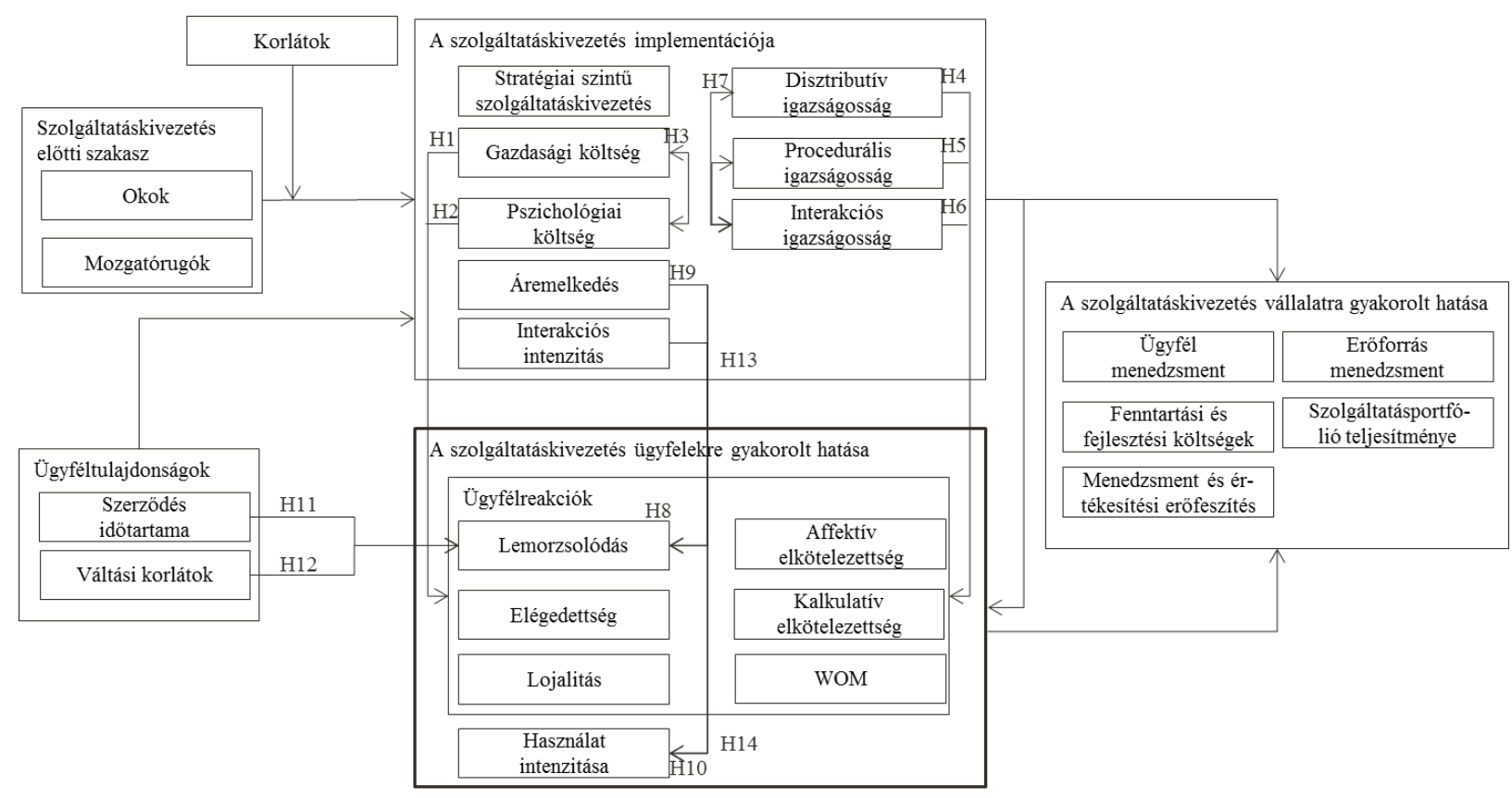

Forrás: saját szerkesztés 
A kutatási hipotéziseket az 6. táblázatban foglaltuk össze:

\section{6. táblázat: Kutatási hipotézisek}

\section{1. tanulmány}

H1: A gazdasági költség növeli a lemorzsolódást, és WOM-ot, és csökkenti az elégedettséget, lojalitást, affektív és kalkulatív

elkötelezettséget szolgáltatáskivezetés esetén.

H2: A pszichológiai költség növeli a lemorzsolódást, és WOM-ot, és csökkenti az elégedettséget, lojalitást, affektív és kalkulatív

elkötelezettséget szolgáltatáskivezetés esetén.

H3: A gazdasági és pszichológiai költségek között interakciós hatás figyelhető meg szolgáltatáskivezetés esetén.

2. tanulmány

3. tanulmány

H4: A disztributív igazságosság csökkenti a lemorzsolódást, és növeli az elégedettséget és lojalitást szolgáltatáskivezetés esetén.

H5: A procedurális igazságosság csökkenti a lemorzsolódást, és növeli az elégedettséget és lojalitást szolgáltatáskivezetés esetén.

H6: Az interakciós igazságosság csökkenti a lemorzsolódást, és növeli az elégedettséget és lojalitást szolgáltatáskivezetés esetén.

H7: A disztributív, procedurális és interakciós igazságosság között interakciós hatás figyelhető meg szolgáltatáskivezetés esetén.
H8: A szolgáltatáskivezetés esetén jelentkező lemorzsolódás magasabb a normál lemorzsolódáshoz képest.

H9: Az áremelkedés csökkenti az ügyfélmegtartás valószínűségét szolgáltatáskivezetés esetén, árcsökkenéssel összehasonlítva. H10: Az áremelkedés növeli a szolgáltatáskivezetést követő használat mértékét árcsökkenéssel összehasonlítva.

H11: A hosszabb szerződéses kapcsolat a szolgáltatóval növeli az ügyfélmegtartás valószínűségét szolgáltatáskivezetés esetén, a rövidebb szerződéses kapcsolattal összehasonlítva. H12: A váltási korlátok növelik az ügyfélmegtartás valószínüségét szolgáltatáskivezetés esetén, a váltási korlátok hiányával összehasonlítva.

H13: Az interakciós intenzitás magasabb szintje növeli az ügyfélmegtartást szolgáltatáskivezetés esetén, az interakciós intenzitás alacsonyabb szintjével összehasonlítva.

H14: Az interakciós intenzitás magasabb szintje növeli a szolglátatáskivezetést követő alacsonyabb használat valószínüségét, az interakciós intenzitás alacsonyabb szintjével összehasonlítva.

\section{Forrás: saját szerkesztés}




\section{KUTATÁSI EREDMÉNYEK: MÉRÉS ÉS ELEMZÉS}

„Az életben nincsen semmi félelmetes. Csak meg kell próbálnunk megérteni.

Ha többet értenénk belöle, már nem is lenne annyi félnivalónk."

(Marie Curie)

A szolgáltatóiparban a portfólió innovációja alapkövetelménynek tekinthetö, de azáltal, hogy az 1980-as évektől kezdve a vállalatok a szolgáltatásfejlesztést helyezték előtérbe, az erőforrásaik nagy részét lekötötték, növelve a fejlesztési és fenntartási költségeiket. Ez túlzsúfolt szolgáltatásportfóliókat eredményezett, amely gátolja a 21 . században elengedhetetlen innovációt.

Ennek eredményeképpen, a szolgáltatáskivezetés a portfólió megújitásának eszközeként tekinthető. A folyamat során azonban kulcsfontosságú, hogy a vállalat ne veszítse el ügyfélbázisát, amely a portfólió egyszerüsítéséből fakadó összes lehetséges előny elérését gátolná, mint például a folyamat optimalizáció, vagy a fenntartási és fejlesztési költségek csökkentése. Vagyis az ügyfélmegtartás a vállalatok számára elengedhetetlen szolgáltatáskivezetés során.

Az 1.1. fejezetben a szakirodalom alapján (Argouslidis, 2007a; Argouslidis \& McLean, 2003; Argouslidis \& Baltas, 2007; Avlonitis \& Argouslidis, 2012) meghatároztuk saját szolgáltatáskivezetés definíciónkat, amelyet kutatásunk során használunk: a szolgáltatáskivezetés egy olyan folyamat, amelynek során a szolgáltatóvállalat kivezeti meglevő szolgáltatásait úgy, hogy szerződött ügyfeleit új szolgáltatáscsomagokra irányítja át.

Definíciónk során tehát kizárólag a teljes kivezetést vizsgáljuk, a szolgáltatáskivezetés részleges formáit, mint például a szolgáltatás lezárást vagy a szolgáltatás összeolvasztást, nem. A szolgáltatás lezárása lehetővé teszi a jelenlegi ügyfeleknek a szolgáltatás további igénybevételét, hiszen csak az új ügyfelek számára nem lesz elérhető a továbbiakban a szolgáltatás. Teljes szolgáltatáskivezetés esetén azonban mind a meglevő, mind az új ügyfelek számára megszünik a szolgáltatás. A szolgáltatáskivezetés típusát tekintve lehet önkéntes, illetve kényszerített, attól függően, hogy az ügyfél önként választ új előfizetést a megszünő helyett vagy a szolgáltató kényszeríti a váltást. Ez erősen befolyásolja az ügyfélmegtartást.

$\mathrm{Az}$ Avlonitis és Argouslidis (2012) által készített metaanalízis szerint a szolgáltatásmarketing szakirodalomban kevés empirikus eredmény található a szolgáltatáskivezetés kimenetével kapcsolatban, amely kutatásunk fö témája. Ez a szakirodalmi rés a vállalati gyakorlatot egyaránt érinti: a portfólió- menedzserek 
bizonytalanok atekintetben, hogy ezekben a nem mindennapi helyzetekben hogyan lehetne az ügyfélmegtartást növelni. A szolgáltatáskivezetés során előforduló, gyakran akár 20-30\%-os lemorzsolódási ráta (Somosi \& Kolos, 2014) elfogadhatatlan a 2-3\%-os telekommunikációs ipari átlagoz képest (ClintWorld GmbH., 2013). Mindezek alapján, a szolgáltatáskivezetés ügyfélmegtartással való kombinációja hozzájárulhat a szakirodalomhoz és a gyakorlathoz egyaránt.

Egy magyar telekommunikációs szolgáltatónál végzett esettanulmányunk eredménye, hogy a szolgáltatáskivezetés szervezése nem stratégiai szinten történik, habár a rendszerekben tárolt szolgáltatások jelentős költségeit egy új szolgáltatásportólfió bevezetése érdekében csökkenteni kell (Somosi \& Kolos, 2014). Vagyis a szolgáltatáskivezetés ügyfélmegtartási stratégiáját a szolgáltatásportfólió- menedzsment részeként tekintjük, melynek sikerességéhez és folyamatának javításához az ügyféloldal mélyebb vizsgálata szükséges. Az 1-3. tanulmányban ezekkel a kérdésekkel foglalkozunk.

Az 1-3. tanulmányban a szolgáltatáskivezetés sikertényezőit tárjuk fel: habár a sikernek számos jelentése lehet, az ügyfélmegtartás és szolgáltatáskivezetés szakirodalomból az látszik, hogy a siker elsősorban a szolgáltatáskivezetési folyamatban érintett ügyfelek alacsonyabb lemorzsolódási rátájával jellemezhető, amely megközelítést kutatásunkban is követjük. A lemorzsolódást, az ügyfélmegtartás operatív mérőszámát használjuk annak eldöntésére, hogy a szolgáltatáskivezetés sikeresnek tekinthetö-e.

\subsection{TANULMÁNY: KíSÉRLETI MÓDSZERTAN: A SZOLGÁLTATÁSKIVEZETÉS KIMENETELÉT MEGHATÁROZÓ SZOLGALTATÁSKIVEZETÉSI ÜGYFÉLREAKCIÓK A TÁRSADALMI CSERE ELMÉLET ALAPJÁN}

Az elözetesen kialakított forgatókönyveken alapuló kísérleti módszertannal célunk a szolgáltatáskivezetés költségeinek (gazdasági és pszichológiai költségek), valamint az ehhez kapcsolódó ügyfélreakciók feltárása, a lemorzsolódást is beleértve, amelyet az ügyfélmegtartás operatív mérőszámaként a szolgáltatáskivezetés sikerességének megítélésére használunk.

Választásunk azért esett a kísérleti módszertanra, mert az ügyfél számára megjelenő gazdasági és pszichológiai költségek, valamint az ügyfélreakciók közötti ok-okozati összefüggések feltárása a cél. Mivel ilyen jellegủ adatok más forrásból (például adatbázisból) nem érhetőek el, az általunk kidolgozott forgatókönyveken alapuló mérést választottuk.

Alternatív lehetőségként felmerülhet a tényleges viselkedés mérése is, azonban ennek számos akadálya van. Egy valós szolgáltatáskivezetési projektben résztvevő ügyfelek közül 
csak kevesen egyeznek bele marketing célú megkeresésbe, így a minta nagyon alacsony lenne. Másfelől a szolgáltatáskivezetés általában nincs megfelelöképpen rendszerezve, ezért limitált számú hasonló múltbeli projekt elérhető el, főként kutatási célokra. Ez részben magyarázatot adhat a több szektoros tanulmányokra a szolgáltatáskivezetés területén: a szolgáltatáskivezetés kutatói gyakran több szektort tartalmazó mintákat használnak, például a telekommunikáció pénzügyi szektorral történő vizsgálatával a megfigyelt esetek számának növelése miatt, amely már ideális a kvantitatív elemzésre.

A kísérleti módszertan legnagyobb előnye tehát a belső érvényesség. A kutatás külső érvényessége megteremtése érdekében eredményeinket egy magyar telekommunikációs szolgáltatótól kapott adatbázis eredményeivel is összevetjük annak érdekében, hogy az ügyfelek valós magatartását is elemezni tudjuk. Ennek alapja egy telekommunikációs vállalat 2012-2013-ban végzett szolgáltatáskivezetési projektje. Az eredményeket a 3. tanulmányban mutatjuk be.

A szakirodalmi áttekintés és az esettanulmány eredményei alapján az 1. tanulmányban a forgatókönyvek elkészítésénél egy 2x2-es between-subject típusú faktoriális elrendezést használtunk ( $\mathrm{N}=163)$ (Somosi \& Kolos, 2017), a gazdasági és pszichológiai költségeket független változókként használva a szolgáltatáskivezetés ügyfelekre gyakorolt hatásának mérésére. Az ügyfelekre gyakorolt hatást a következő függő változók fejezik ki: lemorzsolódás, elégedettség, lojalitás, affektív és kalkulatív elkötelezettség, és WOM.

Mivel Homburg és szerzőtársai (2010) nem határozták meg a pszichológiai költség mérését, és a változó másfajta operacionalizálása sem elérhető a szakirodalomban, a pszichológiai költség jelentését a társadalmi csere elmélet alapján finomítottuk telekommunikációs kontextusban vizsgált kutatásunk során: a gazdasági költség azt jelenti, hogy az új szolgáltatás kedvezőbb vagy kedvezőtlenebb a jelenlegi, kivezetendő szolgáltatásnál (Homburg et. al., 2010), míg a pszichológiai költség arra vonatkozik, hogy az ügyfél kapott-e értesítést közvetlen kommunikáció formájában a szolgáltatáskivezetést megelőzően. Vagyis a pszichológiai költséget úgy definiáltuk, hogy a szolgáltatáskivezetés várható esemény-e az ügyfél számára, amely azt jelenti, hogy az értesítés szerepe kulcsfontosságú: ha az ügyfél a szolgáltatáskivezetést megelőzően írásbeli és szóbeli értesítést is kap az eseményről, a pszichológiai költségek várakozásaink szerint alacsonyabbak lesznek, és ezáltal hatásukat ebben az esetben jelentéktelennek tulajdonítjuk. Mivel az írásos értesítés a szolgáltatáskivezetési folyamat során jogi követelmény, hozzátesszük, hogy a pszichológiai költség arra az esetre vonatkozik, amikor kizárólag írásos értesítést kap az ügyfél a 
szolgáltatáskivezetés előtt, szóbeli felvilágosítást nem, például az ügyfélmegtartási csoporttól érkező hívás formájában (retention call).

A pszichológiai költség tehát arra vonatkozik, hogy az ügyfél kapott-e a szolgáltatáskivezetést megelőzően értesítést az eseményről a levélértesítés jogi követelményén kívül, és a szolgáltató például telefonon is felvette vele a kapcsolatot, vagyis ilyen formában a szolgáltatáskivezetés már nem volt váratlan az ügyfél számára, és ezáltal alacsonyabb mértékü pszichológiai költséggel járt a folyamat. A gazdasági költség a forgatókönyvekben a szolgáltatás árát jelenti az ügyfél számára, amely Dummy változóként definiálunk, vagyis 1-et vesz fel, ha a szolgáltatás ára magasabb a jelenleginél, és 0 -át, ha alacsonyabb az ára a jelenleginél.

Vagyis az 1. tanulmány változói a következők:

- Független változók: gazdasági költség és pszichológiai költség

- Függő változók: lemorzsolódás, elégedettség, lojalitás, affektív és kalkulatív elkötelezettség, WOM

A négy forgatókönyv a következő (11. ábra):

1. Szolgáltatáskivezetés utáni kedvezőbb ár-érték arányú szolgáltatás; az ügyfelet telefonon értesítik szolgáltatáskivezetés előtt.

2. Szolgáltatáskivezetés utáni kedvezőtlenebb ár-érték arányú szolgáltatás; az ügyfelet telefonon értesítik szolgáltatáskivezetés előtt.

3. Szolgáltatáskivezetés utáni kedvezőbb ár-érték arányú szolgáltatás; az ügyfelet nem értesítik telefonon szolgáltatáskivezetés előtt.

4. Szolgáltatáskivezetés utáni kedvezőtlenebb ár-érték arányú szolgáltatás; az ügyfelet nem értesítik telefonon szolgáltatáskivezetés előtt.

\section{1. ábra: Az 1. tanulmány forgatókönyvei}

\begin{tabular}{|c|c|c|}
\hline \multirow{2}{*}{ Gazdasági költség: 0} & Pszichológiai költség: 0 & 1. Szcenárió \\
\hline & Pszichológiai költség: 1 & 3. Szcenárió \\
\hline Gazdr & Pszichológiai költség: 0 & 2. Szcenárió \\
\hline Uazuasagi $\mathrm{n}$ & Pszichológiai költség: 1 & 4. Szcenárió \\
\hline
\end{tabular}

Forrás: saját szerkesztés 
A forgatókönyvek leírása a következö:

- 1. Szcenárió: A mobilszolgáltatód megszünteti a mobil csomagot, amire előfizettél. A váltás előtt a szolgáltató felhív, hogy értesítsen erről és segítsen választani az új előfizetések közül. Jelzed a telefonos ügyintézőnek, hogy nem szeretnéd megszüntetni az előfizetésed, mert tökéletes számodra. Az ügyintéző a jelenlegi előfizetésednél kedvezőbb havidíjú csomagot ajánl, több internettel és alacsonyabb percdíjjal. A hívás után egy héttel megérkezik a levél értesítés is a váltásról.

- 2. Szcenárió: A mobilszolgáltatód megszünteti a mobil csomagot, amire előfizettél. A váltás előtt a szolgáltató felhív, hogy értesítsen erről és segítsen választani az új előfizetések közül. Jelzed a telefonos ügyintézőnek, hogy nem szeretnéd megszüntetni az előfizetésed, mert tökéletes számodra. Az ügyintéző a jelenlegi előfizetésednél magasabb havidíjú csomagot ajánl, kevesebb internettel és magasabb percdíjjal. A hívás után egy héttel megérkezik a levél értesítés is a váltásról.

- 3. Szcenárió: A mobilszolgáltatód megszünteti a mobil csomagot, amire előfizettél. A szolgáltató levélben értesít erről, de nem emlékszel, hogy megkaptad volna a levelet, ezért váratlanul ér a hír. Amikor a telefonos ügyintéző felhív, jelzed neki, hogy nem szeretnéd megszüntetni az elöfizetésed, mert tökéletes számodra. Az ügyintéző a jelenlegi előfizetésednél kedvezőbb havidíjú csomagot ajánl, több internettel és alacsonyabb percdíjjal.

- 4. Szcenárió: A mobilszolgáltatód megszünteti a mobil csomagot, amire előfizettél. A szolgáltató levélben értesít erről, de nem emlékszel, hogy megkaptad volna a levelet, ezért váratlanul ér a hír. Amikor a telefonos ügyintéző felhív, jelzed neki, hogy nem szeretnéd megszüntetni az elöfizetésed, mert tökéletes számodra. Az ügyintéző a jelenlegi előfizetésednél magasabb havidíjú csomagot ajánl, kevesebb internettel és magasabb percdíjjal.

Az 1. tanulmányban a következő hipotéziseket teszteljük:

1. hipotézis: A gazdasági költség növeli a lemorzsolódást, és WOM-ot, és csökkenti az elégedettséget, lojalitást, affektiv és kalkulatív elkötelezettséget szolgáltatáskivezetés esetén.

2. hipotézis: A pszichológiai költség növeli a lemorzsolódást, és WOM-ot, és csökkenti az elégedettséget, lojalitást, affektiv és kalkulativ elkötelezettséget szolgáltatáskivezetés esetén.

3. hipotézis: A gazdasági és pszichológiai költségek között interakciós hatás figyelhetö meg szolgáltatáskivezetés esetén. 


\subsubsection{MINTA}

Az adatgyüjtés online kérdőívvel történt 2014 november- 2015 január között. A résztvevők diákok és azok ismerősei voltak, akiket a közösségi médián keresztül keresztünk meg (LinkedIn és egyetemi levelezőlisták) (Somosi \& Kolos, 2017). A kísérleti módszertan esetén a hallgatói minta rendkívül elterjedt és érvényességét több kutató is alátámasztja (Hocutt et al., 2006).

A forgatókönyvek egy telekommunikációs szolgáltatáskivezetési helyzetet írtak le, amelyben a válaszadóknak a folyamattal és a teljes élmény értékelésével kapcsolatos kérdéseket kellett megválaszolniuk. Egy-egy válaszadó csak egyféle forgatókönyvet értékelt véletlenszerüen, és egy-egy típusú forgatókönyvet 37-44 válaszadó értékelt.

A minta 163 főből áll (16\%-os válaszadási arány). A férfi-női arány a mintában meglehetősen kiegyensúlyozott (59\%, illetve 41\%) és a válaszadók átlagéletkora 31 év.

\subsubsection{SKÁLÁK}

A kísérletben a következő skálákat használjuk, ahol az állításokat 5 fokozatú Likert-skálával mérjük ${ }^{2}$ :

- A lemorzsolódást a következő állításokkal mérjük: "Elfogadnám a szolgáltató ajánlatát" és "Szolgáltatót váltanék a képzelt eset miatt” (Aksoy et al., 2013 alapján). A két állítás átlagolásával határoztuk meg a végleges lemorzsolódási változót.

- Elégedettség és elkötelezettség: Gustafsson és szerzőtársai (2005) skáláit használjuk az elégedettség és elkötelezettség mérésére. Az elégedettséget négy állítással mértük: “Elégedett vagyok a szolgáltató által nyújtott ajánlattal”, “A szolgáltató meghaladja az elvárásaimat”, “A szolgáltató közel áll az általam legjobbnak tartott mobilszolgáltatóhoz". Ezeken az állításokon kívül a még egy elemmel kiegészítettük az elégedettség mérését, Gustafsson (2005) alapján: “A szolgáltató reakcióját megfelelőnek tartom”. Az öt állítás átlagolásával határoztuk meg a végleges elégedettség változót.

Aksoy és szerzőtársainak (2013) eredményei szerint az elégedettség hatással van az NPS (Net Promoter Score, (Reichheld, 2003)) -re, amelyet beemelünk kutatásunkba: „Ajánlanám ismerőseimnek, barátaimnak a szolgáltatót a képzelt eset után” (1-10-es skálán mérve).

\footnotetext{
${ }^{2}$ A kérdöívet magyarul készítettük.
} 
Az affektív elkötelezettséget a következő állításokkal mérjük: “Örülök, hogy a szolgáltató ügyfele lehetek” and “ Megbízom ebben a szolgáltatóban”. A két állítás átlagolásával határoztuk meg a végleges affektív elkötelezettség változót.

A kalkulatív elkötelezettséget a következő állítással mértük: "Megéri számomra a szolgáltató által nyújtott csomagot választani”.

Lojalitás: Zeithaml és szerzőtársai (1996) lojalitás skáláját használtuk a lojalitás mérésére: "A szolgáltatót pozitívan fogom feltüntetni mások előtt”, “Ajánlanám másoknak a szolgáltatót, aki a tanácsomat kéri”, "Bátorítanám ismerőseimet, barátaimat arra, hogy ezt a szolgáltatót válasszák”, "A szolgáltatónál maradnék az elkövetkezendő néhány évben”. A négy állítás átlagolásával határoztuk meg a végleges lojalitás változót.

- WOM: Anderson (1998) eredményei szerint az ügyfelek elégedetlensége magasabb szájreklámhoz vezet, amelyek megalapozták a változóval kapcsolatos hipotéziseinket (H1 és H2). Goyette és szerzőtársai alapján (2010) egy állítást hoztunk létre a WOM mérésére: "Másoknak is elmondanám, hogy mi történt velem".

A mérési skálák esetében a Cronbach alfák 0,784 és 0,951 között vannak (lemorzsolódás: 0,796, elégedettség: 0,784, lojalitás: 0,784, affektív elkötelezettség: 0,804, kalkulatív elkötelezettség: 0,785, WOM: 0,951).

\subsubsection{BELSÖ ÉS KÜLSÖ ÉRVÉNYESSÉG TESZTELÉSE}

A belső érvényesség azt fejezi ki, hogy a függő változókra gyakorolt hatásokat valóban a független változó értékének befolyásolása okozta-e. A külső érvényesség az eredmények általánosíthatóságát jelenti, amelyet a forgatókönyvek hihetőségével mértünk, vagyis a válaszadók mennyire érzik realisztikusnak a vázolt eseteket, valóban előfordulhat-e ilyen eset (Kenesei \& Kolos, 2008).

Négy szakértő (szolgáltatásmarketing tanszéki munkatársak) értékelte a forgatókönyveket, valamint a kérdőívet. Ez alapján a szóhasználatban apróbb változtatásokat tettünk. Ezt követően Perdue és Summers (1986) alapján, egy külön kvantitatív kutatás keretében teszteltük a belső érvényességet, amely hatékonynak mutatkozott, szignifikáns különbséggel a teszt és kontrollcsoportok között az összes feltétel esetében ( $\mathrm{N}=52)$.

A belső érvényesség kidolgozásában Homburg és szerzőtársai (2010 533. o.) ajánlásai szerint jártunk el, akik a gazdasági költségeket az észlelt gazdasági teherként, illetve költségekként írták le, míg a pszichológiai költségeket a bizonytalanság, kétség és kellemetlen, feszült belső állapottal jellemezték, disszonáns ismeretekkel. 
A két független változó belső érvényességi skálái a következőek: Cannon és Homburg (2001), és Montgomery és szerzőtársai (2005) alapján, a gazdasági költséget a következő állítással mértük: "Úgy érzem, hogy anyagi szempontból veszteség ér”, ahol M (gazdasági költség) $=4 ., 48$ vs. $M$ (nincs gazdasági költség) $=1.56, \quad F(1.51)=118,73, \quad p<0.000 . \quad$ A pszichológiai költséget a következő állítással mértük (Dwyer et al., 1987; Noordweier et al., 1990; Arend, 2006): “Az eset után kétségek merülnek fel bennem a szolgáltató megbízhatóságával kapcsolatban”, ahol $M$ (pszichológiai költség) $=3.73$ vs. $M$ (nincs pszichológiai költség) $=3.13, F(1.50)=3.117, \mathrm{p}<0.01$. A kidolgozott forgatókönyvek tehát megfelelően jelenítik meg a független változókat.

Külső érvényesség szempontjából a forgatókönyvek realisztikusságát is ellenőriztük a következő két állítással: "Úgy érzem, hogy ez az eset realisztikus" és "Ez az eset megtörténhet a mindennapi életben”, ahol az állítások átlagértékei egy 5 fokozatú Likertskálán 3,27 és 3,80 között vannak a 4 forgatókönyv esetében, azt sugallva, hogy a forgatókönyvek inkább realisztikusak. Emellett egy telekommunikációs szolgáltató menedzsere adott javaslatokat a forgatókönyvekkel kapcsolatban és összességében realisztikusnak ítélte meg őket, amelyek megfelelnek a mindennapi gyakorlatnak.

\subsubsection{EREDMÉNYEK}

A gazdasági és pszichológiai költség lemorzsolódásra, elégedettségre, lojalitásra, elkötelezettségre és WOM-ra gyakorolt hatását faktoriális ANOVA-val teszteltük ${ }^{3}$ (Field, 2003), SPSS szoftver segítségével (Mitev \& Sajtos, 2007).

A fó hatásokkal kapcsolatos eredményeket a négy forgatókönyv esetén a 7 . táblázat foglalja össze.

Gazdasági költség (0: nincs költség; 1: van költség)

A gazdasági költség esetében azt láthatjuk, hogy az összes függő változó hipotéziseinknek megfelelöen változik: a gazdasági költség növeli a lemorzsolódást és WOM-ot, míg csökkenti az elégedettséget, lojalitást, affektív és kalkulatív elkötelezettséget. Vagyis a H1-et elfogadjuk.

Pszichológiai költség (0: nincs költség; 1: van költség)

A pszichológiai költség csökkenti az elégedettséget, lojalitást és affektív elkötelezettséget várakozásainknak megfelelően, azonban a pszichológiai költség lemorzsolódásra, kalkulatív elkötelezettségre és WOM-ra gyakorolt hatása nem szignifikáns. Vagyis a H2 csak részben elfogadható.

\footnotetext{
${ }^{3}$ Az elemzés során 5\%-os szignifikancia szintet használunk.
} 


\section{A gazdasági és pszichológiai költségek közötti interakció}

A gazdasági és pszichológiai költség közötti interakciók meglepő eredménnyel szolgáltak: az ügyfelek elégedettebbek, lojálisabbak és elkötelezettebbek, és nem hagynák el a szolgáltatót egy, a jelenleginél kedvezőtlenebb ajánlat esetén, amennyiben erről nem kapnak előzetes értesítést. A kalkulatív elkötelezettség és WOM nem szignifikánsak ebben az esetben.

Mindezek alapján felmerül az ajánlatok komplexitásának kérdése: úgy érezzük, hogy az értesítés figyelemfelkeltő szereppel bír, és ezáltal a gazdasági költségek jelenléte az ügyfél számára sokkal explicitebbé válik. Ezt már az esettanulmány során is említette egyik interjúalanyunk (3.2. fejezet).

A gazdasági költség hiánya és pszichológiai költség közti interakciók viszont már megfelelnek várakozásainknak: az ügyfelek elégedettebbek, lojálisabbak és elkötelezettebbek és elhagynák a szolgáltatót, amennyiben egy kedvezőbb ajánlatot kapnak a jelenleginél, de erről a szolgáltató nem értesíti őket a szolgáltatáskivezetés előtt, azzal a helyzettel összehasonlítva, amikor kapnak ilyen értesítést. A kalkulatív elkötelezettség és a WOM itt sem szignifikánsak.

Ez a második interakció is felveti az ajánlatok komplexitásának kérdését, hiszen ez utóbbi helyzet arra utal, hogy az ügyfelek hiába kapnak egy kedvezőbb ajánlatot jelenlegi előfizetésüknél, ha a szolgáltató nem keresi fel őket telefonon is, nem ismerik fel az új ajánlat hozzáadott értékét a jelenlegivel összehasonlítva.

Ezek az eredmények összességében azt jelentik, hogy a H3-at elfogadhatjuk.

7. táblázat: A függő változók átlagértékei a független változók szerint képzett csoportokban (a szignifikáns átlagértékek vastag kiemeléssel szerepelnek)

\begin{tabular}{|c|c|c|c|c|c|c|c|}
\hline & & \multicolumn{6}{|c|}{ Függő változók } \\
\hline $\begin{array}{l}\text { Független } \\
\text { változók }\end{array}$ & & Elégedettség & Lojalitás & $\begin{array}{l}\text { Lemor- } \\
\text { zsolódás }\end{array}$ & $\begin{array}{c}\text { Affektív } \\
\text { elkötelezettség }\end{array}$ & $\begin{array}{c}\text { Kalkulatív } \\
\text { elkötelezettség }\end{array}$ & WOM \\
\hline \multirow{4}{*}{$\begin{array}{c}\text { Gazdasági } \\
\text { költség }\end{array}$} & & $\mathrm{F}=335,97$ & $\mathrm{~F}=256,58$ & $\mathrm{~F}=261,85$ & $\mathrm{~F}=136,98$ & $\mathrm{~F}=335,655$ & $\mathrm{~F}=10,251$ \\
\hline & & sig. 0,000 & sig. 0,000 & sig. 0,000 & sig. 0,000 & sig. 0,000 & sig. 0,002 \\
\hline & Van & 1,62 & 2,41 & $\mathbf{3 , 8 8}$ & 1,66 & 1,63 & 4,26 \\
\hline & Nincs & 3,68 & 2,69 & 1,81 & 3,19 & 4,07 & 3,75 \\
\hline \multirow{4}{*}{$\begin{array}{c}\text { Pszichológiai } \\
\text { költség }\end{array}$} & & $\mathrm{F}=6,14$ & $\mathrm{~F}=6,965$ & $\mathrm{~F}=0,39$ & $\mathrm{~F}=5,38$ & $\mathrm{~F}=0,436$ & $\mathrm{~F}=3,236$ \\
\hline & & sig. 0,014 & sig. 0,009 & sig. 0,533 & sig. 0,022 & sig. 0,510 & sig. 0,074 \\
\hline & Van & 2,45 & 1,63 & 2,87 & 2,23 & 2,80 & 4,17 \\
\hline & Nincs & 2,69 & 3,64 & 2,99 & 2,49 & 2,69 & 3,88 \\
\hline Gazdasági & Pszichológiai & $\mathrm{F}=9,83$ & $\mathrm{~F}=14,309$ & $\mathrm{~F}=11,38$ & $\mathrm{~F}=9,09$ & $\mathrm{~F}=0,764$ & $\mathrm{~F}=0,358$ \\
\hline költség & költség & sig. 0,002 & sig. 0,000 & sig. 0,001 & sig. 0,003 & sig. 0,383 & sig. 0,550 \\
\hline
\end{tabular}




\begin{tabular}{|c|c|r|r|r|r|r|r|}
\multirow{3}{*}{ Van } & Van & $\mathbf{1 , 6 6}$ & $\mathbf{1 , 7 0}$ & $\mathbf{3 , 6 3}$ & $\mathbf{1 , 7 0}$ & 1,73 & 4,45 \\
\cline { 2 - 8 } & Nincs & $\mathbf{1 , 5 9}$ & $\mathbf{1 , 5 5}$ & $\mathbf{4 , 1 4}$ & $\mathbf{1 , 6 1}$ & 1,52 & 4,07 \\
\hline \multirow{3}{*}{ Nincs } & Van & $\mathbf{3 , 3 7}$ & $\mathbf{3 , 2 4}$ & $\mathbf{1 , 9 9}$ & $\mathbf{2 , 8 4}$ & 4,05 & 3,84 \\
\cline { 2 - 8 } & Nincs & $\mathbf{4 , 0 0}$ & $\mathbf{4 , 0 5}$ & $\mathbf{1 , 6 4}$ & $\mathbf{3 , 5 4}$ & 4,08 & 3,65 \\
\hline
\end{tabular}

\section{Forrás: saját szerkesztés}

Interakciós hipotéziseinket tehát elfogadhatjuk: a két változó közötti interakciós hatás egyértelmü, és csak a gazdasági költség pszichológiai költséggel való interakciója kétértelmű, amely azt jelenti, hogy a gazdasági költségnek erősebb hatása van az ügyfélreakciókra szolgáltatáskivezetés esetén, mint a pszichológiai költségnek.

A fő hatásokat jelentős kettős interakciók is jellemzik, amelyeket a 12. ábrán mutatunk be. Gazdasági költség esetén a pszichológiai költség (nem hívják fel az ügyfelet) nem okoz eltérést az elégedettségben (alacsony az elégedettségi mutató). Ha azonban nincs gazdasági költség, a pszichológiai költség hiánya (felhívják az ügyfelet) megnöveli az elégedettséget, előzetes várakozásainknak megfelelően. A lojalitás és affektív elkötelezettség hasonló mintázatot követ. A lemorzsolódás esetén azonban, ha nincs gazdasági költség, a pszichológiai költség (nem hívják fel az ügyfelet) növeli a lemorzsolódást, viszont, ha van gazdasági költség, a pszichológiai költség hiánya (felhívják az ügyfelet) növeli a lemorzsolódást.

$\mathrm{Az}$ eredmények tehát alátámasztják a $\mathrm{H} 1$-et, és $\mathrm{H} 3$-at, valamint a $\mathrm{H} 2$ részben megerösítést nyert.

\section{2. ábra: A gazdasági és pszichológiai költségek interakciói ${ }^{4}$}
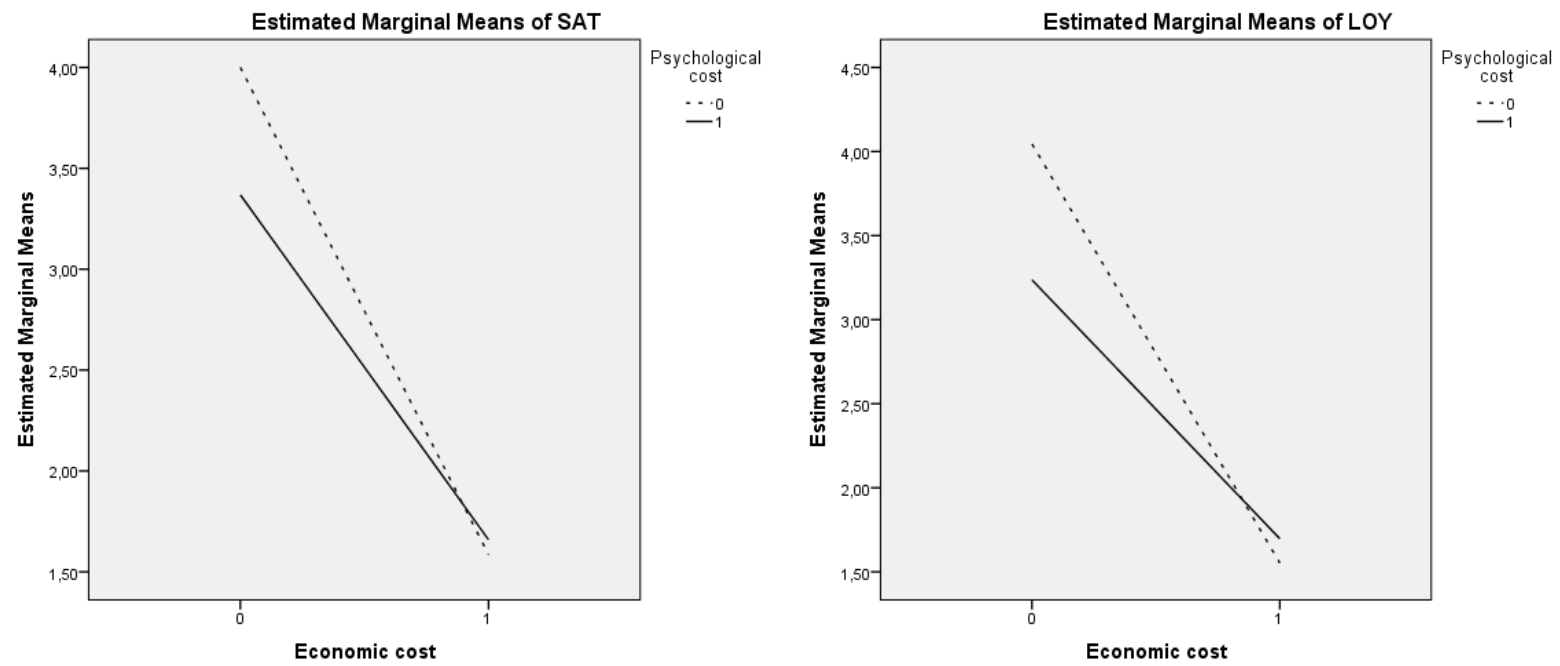

${ }^{4}$ Jelmagyarázat: Economic cost $=$ gazdasági költség, Psychological cost $=$ pszichológiai költség, SAT= elégedettség, LOY= lojalitás, CHURN= lemorzsolódás, AFFCOMM= affektív elkötelezettség 

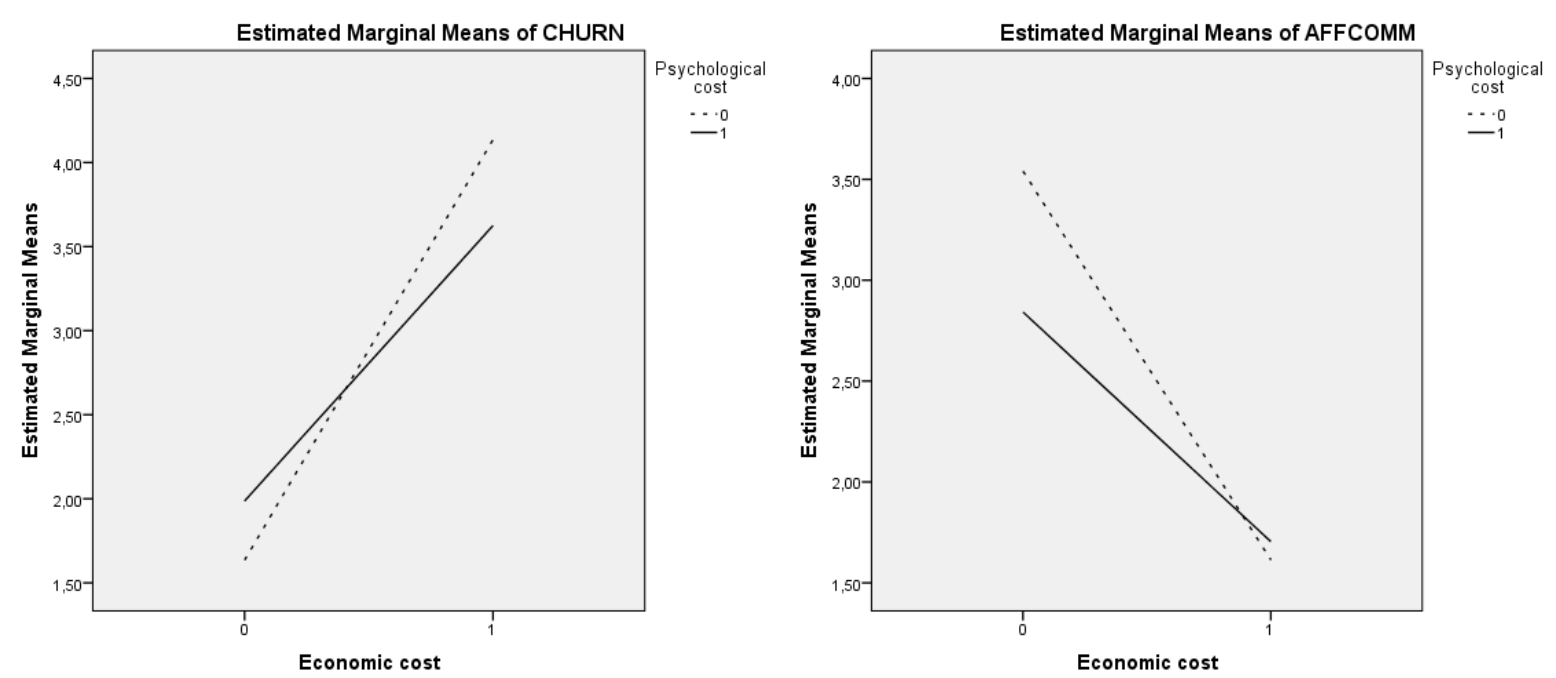

\section{Forrás: saját szerkesztés}

$\mathrm{Az}$ 1. tanulmány eredményei szerint a gyakorlati szakembereknek tudatában kell lenniük a pszichológiai költség vártnál erősebb hatásával: az ügyféllel való kapcsolatfelvétel módja erősebben befolyásolja az ügyfélmegtartást, mint az ajánlat minősége. Az ajánlat írott formában valószínűleg nehezen értelmezhető az ügyfél számára, és ezáltal a verbális kommunikáció felhívja a figyelmét az ajánlat részleteire. Ennek eredményeképpen, rosszabb ajánlat esetén az ügyfelek nagyobb valószínűséggel váltanak szolgáltatót.

A pszichológiai költség szerepét szeretnénk hangsúlyozni: kedvezőtlenebb ajánlat esetén a kivezetés előtti szóbeli értesítés hiánya alacsonyabb, míg kedvezőbb ajánlat esetén magasabb lemorzsolódáshoz vezet. Vagyis nemcsak az ajánlat minősége határozza meg az ügyfélmegtartást. Meglepő módon az ügyféllel való verbális interakció az ajánlat minőségétől függően eltérő hatást vált ki: az új ajánlatot kellene jobban hangsúlyozni kedvezőbb ajánlat esetén, feltételezve, hogy az ügyfél nem ismeri fel az új ajánlat kedvező feltételeit. Éppen ellenkezőleg, a kedvezőtlenebb ajánlat esetében ezért azt feltételezhetnénk, hogy az ügyfél nem ismeri fel a pontos új feltételeket, de ha a szolgáltató elmagyarázza azokat az ügyfélnek, akkor az ügyfél elhagyhatja a szolgáltatót. Összességében tehát az interakciót óvatosan kell kezelni, az ajánlat minősége ugyanis befolyásolja a pszichológiai költség ügyfelekre gyakorolt hatását. 


\subsection{AZ 1. TANULMÁNY TANULSÁGAI}

$\mathrm{Az}$ 1. tanulmány rávilágított arra, hogy a szolgáltatáskivezetés hogyan hat az ügyfélmegtartásra. Kísérleti módszertant használtunk a szolgáltatáskivezetés és annak sikertényezői, elsődlegesen a lemorzsolódás és más ügyfélreakcióhoz kötöző változók (elégedettség, lojalitás, elkötelezettség, WOM) közti kapcsolat feltárására. Az elégedettséghez, lojalitáshoz és elkötelezettséghez kötődő hipotéziseket elfogadtuk, kizárólag a gazdasági és pszichológiai költségek közötti interakciók eredménye lett meglepő. A gazdasági költségtől eltekintve, a pszichológiai költségnek figyelemfelkeltő szerepe van az ügyfelek számára. A szolgáltatóval való kapcsolat hiánya meghatározza az elégedettséget, lojalitást, elkötelezettséget és lemorzsolódást. Ha az ügyfél kedvezőbb ajánlatot kapott, de a szolgáltató erről telefonon előzetesen nem értesítette, az ügyfél nagyobb valószínűséggel hagyhatja el a vállalatot azzal a helyezettel összehasonlítva, amikor előzetes telefonos értesítésben is részesült. A kedvezőtlenebb ajánlat esetében viszont az előzetes hívás hiánya meglepő módon javítja a helyzet kimenetelét, és csökkenti a lemorzsolódást. Vagyis tulajdonképpen a szolgáltató magyarázata hívja fel az ügyfél figyelmét a gazdasági nyereség vagy veszteség tényére.

Az eredmények azt sugallják, hogy az ajánlatok önmagukban nem egyértelmüek az ügyfelek számára és a szolgáltatóval való közvetlen kapcsolat a szolgáltatáskivezetést megelözően kulcsfontosságú. Az ügyfélmegtartás szempontjából ez a tény áthelyezheti a hangsúlyt a „hard faktorok” (pl. az új ajánlat árazása szolgáltatáskivezetés során) felől a „soft faktorok" (pl. az ügyfél előzetes tájékoztatása, a tájékoztatás minősége szolgáltatáskivezetés során) irányába.

Az 1. tanulmány egyik limitációja, hogy kényelmi mintavételt alkalmaztunk az adatfelvétel során, habár a szakirodalom alapján a reprezentatív minta a kísérleti módszertan esetében nem követelmény.

Továbbá, a pszichológiai költség mérését pontosítani kell, mivel az ügyfél telefonon történő értesítése -noha ez az üzleti gyakorlatban ténylegesen alkalmazott eszköz- csak közvetett módon jeleníti meg a pszichológiai költséget. Az eredmények szerint az ajánlatok komplexitása jelentős eltéréseket okozott a függő változókra gyakorolt hatások tekintetében, ezért az ajánlatok komplexitását mérő változót, és a pszichológiai költség további elemeit (mint például a váltási költségek: idő, és az ügyfél egyéb erőfeszítései a versenytársi ajánlatok elemzésére, a szolgáltatóval való személyes interakció, a számhordozással kapcsolatos esetleges problémák) érdemes lenne bevonni a vizsgálatba. 
Ezen kívül, ahogyan az esettanulmány is kiemelte, a szerződéses és szerződési időn kívüli ügyfeleket azonosítani kell, hiszen a gazdasági költségek jelentősen eltérnek a két csoport esetében (elsősorban a szerződés lejárta előtti kötbér fizetési kötelezettség miatt).

Vagyis az 1. tanulmány alapján a hipotéziseink tekintetében a következöket állapíthatjuk meg:

1. hipotézis: A gazdasági költség növeli a lemorzsolódást, és WOM-ot, és csökkenti az elégedettséget, lojalitást, affektív és kalkulativ elkötelezettséget szolgáltatáskivezetés esetén. elfogadva (7. táblázat)

2. hipotézis: A pszichológiai költség növeli a lemorzsolódást, és WOM-ot, és csökkenti az elégedettséget, lojalitást, affektiv és kalkulativ elkötelezettséget szolgáltatáskivezetés esetén.- részben elfogadva (7. táblázat)

3. hipotézis: A gazdasági és pszichológiai költségek között interakciós hatás figyelhetö meg szolgáltatáskivezetés esetén.- elfogadva (7. táblázat)

\subsection{TANULMÁNY: KíSÉRLETI MóDSZERTAN: A SZOLGALTATÁSKIVEZETÉS KIMENETELÉT MEGHATÁROZÓ SZOLGÁLTATÁSKIVEZETÉSI ÜGYFÉLREAKCIÓK AZ IGAZSÁGOSSÁG ELMÉLET ALAPJÁN}

A szolgáltatáskivezetés ügyfelekre gyakorolt hatásának empirikus eredményeinek gazdagítása céljából egy másik elméleti megközelítést is alkalmaztunk. Az igazságosság elméletet választottuk, mivel ezt az elméletet már sikeresen alkalmazták a szolgáltatási hibák kezelésének (service recovery) magyarázatára. A szolgáltatási hiba, bizonyos értelemben hasonlónak tekinthető a szolgáltatáskivezetéshez, ahogyan korábban már utaltunk rá. A szolgáltatáskivezetés a vállalat döntése, amely váratlan az ügyfél számára, és abból kifolyólag, hogy a szolgáltatás már nem elérhető a későbbiekben az ügyfél számára (hiszen a szolgáltatáskivezetést teljes kivezetésként definiáltuk), az ügyfél szemszögéböl a folyamat tulajdonképpen a jelenlegi szolgáltatás hibájaként is értelmezhető.

$\mathrm{Az}$ 1. tanulmányhoz hasonlóan a kísérleti módszertant választottuk a szolgáltatáskivezetés ügyfelekre gyakorolt hatásának mérésére, de a társadalmi csere elmélet helyett a 2. tanulmányban az igazságosság elméletet használtuk a korábbi kísérlet eredményeinek finomítására.

Az igazságosság elmélet szakirodalmi áttekintése alapján láthattuk, hogy az igazságosság három fö dimenzióval rendelkezik: disztributív, procedurális és interakciós igazságosság. A disztributív igazságosság azt fejezi ki, hogy a szolgáltatáskivezetés után 
ajánlott szolgáltatás összességében kedvezőbb vagy kedvezőtlenebb a jelenleginél, az ügyfél számára felmerülő költségek alapján. A procedurális igazságosság azt méri, hogy az ügyfél mennyi időt, pénzt és energiát kell, hogy áldozzon a szolgáltatáskivezetés után elérhető új szolgáltatás igénybevétele érdekében. Az interakciós igazságosság pedig az interakció minőségét, az udvarias bánásmódot és a vállalat képviselője által tanúsított összességében pozitív attitüdöt fejezi ki az ügyfél számára.

Ezek a dimenziók úgy érezzük, pontosabban ragadják meg a társadalmi csere elmélet szerint gazdasági és pszichológiai költségként definiált költségeket, mivel az igazságosság három eleme a folyamat és a bánásmód minőségét is figyelembe veszi.

$\mathrm{Az}$ igazságosság mindhárom elemét Dummy változókkal jelenítjük meg a forgatókönyvekben, amelyek 1-et vesznek fel, ha az igazságosság adott dimenziója jelen van, és 0 -át, ha az igazságosság adott dimenziója nem szerepel a forgatókönyvben.

A szakirodalmi áttekintés, és az esettanulmány, valamint 1. tanulmány eredményei alapján a 8 forgatókönyv elkészítésénél egy $2 \times 2 \times 2$ between-subject típusú faktoriális elrendezést használtunk $(\mathrm{N}=178)$, a disztributív, procedurális és interakciós igazságosság Dummy független változókként való használatával (Blodgett et al., 1997) és a következő függő változókkal: lemorzsolódás, elégedettség és lojalitás. Az igazságosság elmélet alapján mértük a szolgáltatáskivezetés ügyfelekre gyakorolt hatását.

A forgatókönyvek egy telekommunikációs szolgáltatáskivezetési helyzetet írtak le, a szolgáltató különböző stratégiái szerint: a szolgáltató vagy felhívta az ügyfelet a levél kiküldése után (az írásbeli értesítés jogi követelmény), vagy az ügyfélnek kellett felhívnia a szolgáltatót, az egész helyzet szokatlansága és az új ajánlat összetettsége miatt.

A forgatókönyveket már az 1. tanulmány során részben teszteltük, de az igazságosság elmélet alapján finomítottuk öket, mivel a procedurális és interakciós igazságosság összességében jobban megragadják az ügyfél pszichológiai költségeit szolgáltatáskivezetés esetén. Ezen kívül az igazságosság skálájának tesztelésével és a forgatókönyvek realitásának vizsgálatával végeztük a belső és külső érvényesség vizsgálatát.

Vagyis a 2. tanulmány szerkezete a következő:

- Független változók: disztributív, procedurális és interakciós igazságosság

- Függő változók: lemorzsolódás, elégedettség és lojalitás 
A nyolc forgatókönyv a következő (13. ábra):

1. Szolgáltatáskivezetés utáni kedvezőtlenebb ár-érték arányú szolgáltatás; az ügyfélnek többször kell felkeresnie a szolgáltatót; úgy tünik, hogy az alkalmazottak nem törödnek az ügyféllel

2. Szolgáltatáskivezetés utáni kedvezőbb ár-érték arányú szolgáltatás; az ügyfélnek többször kell felkeresnie a szolgáltatót; úgy tünik, hogy az alkalmazottak nem törődnek az ügyféllel

3. Szolgáltatáskivezetés utáni kedvezőtlenebb ár-érték arányú szolgáltatás; az ügyfélnek többször kell felkeresnie a szolgáltatót; úgy tünik, hogy az alkalmazottak törődnek az ügyféllel

4. Szolgáltatáskivezetés utáni kedvezőbb ár-érték arányú szolgáltatás; az ügyfélnek többször kell felkeresnie a szolgáltatót; úgy tünik, hogy az alkalmazottak törődnek az ügyféllel

5. Szolgáltatáskivezetés utáni kedvezőtlenebb ár-érték arányú szolgáltatás; az ügyfélnek nem kell felkeresnie a szolgáltatót; úgy tünik, hogy az alkalmazottak nem törődnek az ügyféllel

6. Szolgáltatáskivezetés utáni kedvezőbb ár-érték arányú szolgáltatás; az ügyfélnek nem kell felkeresnie a szolgáltatót; úgy tűnik, hogy az alkalmazottak nem törődnek az ügyféllel

7. Szolgáltatáskivezetés utáni kedvezőtlenebb ár-érték arányú szolgáltatás; az ügyfélnek nem kell felkeresnie a szolgáltatót; úgy tünik, hogy az alkalmazottak törődnek az ügyféllel

8. Szolgáltatáskivezetés utáni kedvezőbb ár-érték arányú szolgáltatás; az ügyfélnek nem kell felkeresnie a szolgáltatót; úgy tünik, hogy az alkalmazottak törődnek az ügyféllel

\section{3. ábra: A 2. tanulmány forgatókönyvei}

\begin{tabular}{|c|c|c|c|}
\hline & & Interakciós ig.: 0 & 1. Szcenárió \\
\hline Dicatributín ia $\cdot 0$ & & Interakciós ig.: 1 & 3. Szcenárió \\
\hline Diszthoutiv Ig.. 0 & & Interakciós ig.: 0 & 5. Szcenárió \\
\hline & eaur & Interakciós ig.: 1 & 7. Szcenárió \\
\hline & ólic ig. 0 & Interakciós ig.: 0 & 2. Szcenárió \\
\hline Diantribut'́t in 1 & eduralis 1g.: U & Interakciós ig.: 1 & 4. Szcenárió \\
\hline DISZTIOUULV Ig.. I & & Interakciós ig.: 0 & 6. Szcenárió \\
\hline & s $19 . .1$ & Interakciós ig.: 1 & 8. Szcenárió \\
\hline
\end{tabular}

Forrás: saját szerkesztés 
A forgatókönyvek leírása a következö:

- 1. Szcenárió: A mobilszolgáltatód megszünteti a mobil csomagot, amire előfizettél., ami azt jelenti, hogy a jelenlegi előfizetésed feltételei a továbbiakban már nem lesznek elérhetőek. A mobilszolgáltató levélben értesít erről, amelyben új feltételeket ajánlanak számodra. A levél nem világos számodra, ezért úgy döntesz, hogy felhívod a mobilszolgáltatót. Többszöri hívás és hosszú várakozás után végre sikerül egy hozzáértő emberrel beszélned. Az ügyintéző barátságtalan és úgy tünik, hogy nem figyel oda az igényeidre, és a jelenlegi előfizetésednél összességében 10\%-kal drágább csomagot ajánl.

- 2. Szcenárió: A mobilszolgáltatód megszünteti a mobil csomagot, amire előfizettél., ami azt jelenti, hogy a jelenlegi előfizetésed feltételei a továbbiakban már nem lesznek elérhetőek. A mobilszolgáltató levélben értesít erről, amelyben új feltételeket ajánlanak számodra. A levél nem világos számodra, ezért úgy döntesz, hogy felhívod a mobilszolgáltatót. Többszöri hívás és hosszú várakozás után végre sikerül egy hozzáértő emberrel beszélned. Az ügyintéző barátságtalan és úgy tünik, hogy nem figyel oda az igényeidre, és a jelenlegi előfizetésednél összességében 10\%-kal kedvezőbb csomagot ajánl.

- 3. Szcenárió: A mobilszolgáltatód megszünteti a mobil csomagot, amire előfizettél., ami azt jelenti, hogy a jelenlegi előfizetésed feltételei a továbbiakban már nem lesznek elérhetőek. A mobilszolgáltató levélben értesít erről, amelyben új feltételeket ajánlanak számodra. A levél nem világos számodra, ezért úgy döntesz, hogy felhívod a mobilszolgáltatót. Többszöri hívás és hosszú várakozás után végre sikerül egy hozzáértő emberrel beszélned. Az ügyintéző barátságos és úgy tünik, hogy odafigyel az igényeidre, és a jelenlegi előfizetésednél összességében 10\%-kal drágább csomagot ajánl.

- 4. Szcenárió: A mobilszolgáltatód megszünteti a mobil csomagot, amire előfizettél., ami azt jelenti, hogy a jelenlegi előfizetésed feltételei a továbbiakban már nem lesznek elérhetőek. A mobilszolgáltató levélben értesít erről, amelyben új feltételeket ajánlanak számodra. A levél nem világos számodra, ezért úgy döntesz, hogy felhívod a mobilszolgáltatót. Többszöri hívás és hosszú várakozás után végre sikerül egy hozzáértő emberrel beszélned. Az ügyintéző barátságos és úgy tűnik, hogy odafigyel az igényeidre, és a jelenlegi előfizetésednél összességében 10\%-kal kedvezőbb csomagot ajánl.

- 5. Szcenárió: A mobilszolgáltatód megszünteti a mobil csomagot, amire előfizettél., ami azt jelenti, hogy a jelenlegi előfizetésed feltételei a továbbiakban már nem lesznek elérhetőek. A mobilszolgáltató levélben értesít erről, amelyben új feltételeket ajánlanak számodra. A levél nem világos számodra, de a szolgáltató szerencsére felhív, hogy 
tájékoztasson a változásokról. Az ügyintéző barátságtalan és úgy tünik, hogy nem figyel oda az igényeidre, és a jelenlegi előfizetésednél összességében 10\%-kal drágább csomagot ajánl.

- 6. Szcenárió: A mobilszolgáltatód megszünteti a mobil csomagot, amire előfizettél., ami azt jelenti, hogy a jelenlegi előfizetésed feltételei a továbbiakban már nem lesznek elérhetőek. A mobilszolgáltató levélben értesít erről, amelyben új feltételeket ajánlanak számodra. A levél nem világos számodra, de a szolgáltató szerencsére felhív, hogy tájékoztasson a változásokról. Az ügyintéző barátságtalan és úgy tünik, hogy nem figyel oda az igényeidre, és a jelenlegi előfizetésednél összességében 10\%-kal kedvezőbb csomagot ajánl.

- 7. Szcenárió: A mobilszolgáltatód megszünteti a mobil csomagot, amire előfizettél., ami azt jelenti, hogy a jelenlegi előfizetésed feltételei a továbbiakban már nem lesznek elérhetőek. A mobilszolgáltató levélben értesít erről, amelyben új feltételeket ajánlanak számodra. A levél nem világos számodra, de a szolgáltató szerencsére felhív, hogy tájékoztasson a változásokról. Az ügyintéző barátságos és úgy tünik, hogy odafigyel az igényeidre, és a jelenlegi előfizetésednél összességében 10\%-kal drágább csomagot ajánl.

- 8. Szcenárió: A mobilszolgáltatód megszünteti a mobil csomagot, amire előfizettél., ami azt jelenti, hogy a jelenlegi előfizetésed feltételei a továbbiakban már nem lesznek elérhetőek. A mobilszolgáltató levélben értesít erről, amelyben új feltételeket ajánlanak számodra. A levél nem világos számodra, de a szolgáltató szerencsére felhív, hogy tájékoztasson a változásokról. Az ügyintéző barátságos és úgy tünik, hogy odafigyel az igényeidre, és a jelenlegi előfizetésednél összességében 10\%-kal kedvezőbb csomagot ajánl.

A 2. tanulmányban a következő hipotéziseket teszteljük:

4. hipotézis: A disztributív igazságosság csökkenti a lemorzsolódást, és növeli az elégedettséget és lojalitást szolgáltatáskivezetés esetén.

5. hipotézis: A procedurális igazságosság csökkenti a lemorzsolódást, és növeli az elégedettséget és lojalitást szolgáltatáskivezetés esetén.

6. hipotézis: Az interakciós igazságosság csökkenti a lemorzsolódást, és növeli az elégedettséget és lojalitást szolgáltatáskivezetés esetén.

7. hipotézis: A disztributív, procedurális és interakciós igazságosság között interakciós hatás figyelhetö meg szolgáltatáskivezetés esetén. 


\subsubsection{MINTA}

Az adatgyüjtés 2016 december és 2017 április között történt Bécsben, online kérdöív segítségével. Egy bécsi egyetem diákjai vettek részt a kutatásban, akiket egyetemi levelezőlistán keresztül toboroztunk. A kísérleti módszertan esetén a hallgatói minta rendkívül elterjedt és érvényességét több kutató is alátámasztja (Hocutt et al., 2006).

A forgatókönyvek egy telekommunikációs szolgáltatáskivezetési helyzetet írnak le, és a válaszadók a folyamattal kapcsolatos kérdésekre válaszoltak és az élményt összességében értékelték.

A kérdőíves megkérdezés során kapott adatbázis az adattisztítást követően 178 értékelhető választ tartalmaz (0,72\%-os válaszadási arány). A férfi-női arány meglehetősen kiegyensúlyozott a mintában $(49,1 \%$ és $50,9 \%)$ és a válaszadók átlagéletkora 28 év. A válaszadók 63\%-a Bécsben él, és 58,4\%-a osztrák. Egy-egy válaszadó csak egyféle forgatókönyvet értékelt véletlenszerüen, és egy-egy típusú forgatókönyvet 79-91 válaszadó értékelt.

\subsubsection{SKÁLÁK}

A kísérletben a következő skálákat használjuk, ahol az állításokat 5 fokozatú Likert-skálával mérjük ${ }^{5}$ :

- A lemorzsolódást a következő állításokkal mérjük: "Ha ebben a helyzetben lennék, nem fogadnám el a szolgáltató ajánlatát", "Szolgáltatót váltanék a képzelt eset miatt", and "Ha ebben a helyzetben lennék, ezt a szolgáltatót a jövőben soha többet nem keresném fel” (Aksoy et al., 2013 alapján). A három állítás átlaga képezi a végső lemorzsolódás változót.

- Elégedettség: Gustafsson és szerzőtársai (2005) skáláit használjuk az elégedettség mérésére. Az elégedettséget négy állítással mérjük: "Elégedett vagyok a szolgáltató által nyújtott ajánlattal”, “A szolgáltató meghaladja az elvárásaimat”, “A szolgáltató közel áll az általam legjobbnak tartott mobilszolgáltatóhoz”. Ezeken az állításokon kívül a még egy elemmel kiegészítettük az elégedettség mérését, Gustafsson (2005) alapján: “A szolgáltató reakcióját megfelelőnek tartom”. A négy állítás átlaga képezi a végső elégedettség változót.

- Lojalitás: Zeithaml és szerzőtársai (1996) lojalitás skáláját használjuk a lojalitás mérésére: "A szolgáltatót pozitívan fogom feltüntetni mások előtt”, “Ajánlanám

\footnotetext{
${ }^{5}$ A kérdőívet angolul készítettük.
} 
másoknak a szolgáltatót, aki a tanácsomat kéri”, "Bátorítanám ismerőseimet, barátaimat arra, hogy ezt a szolgáltatót válasszák", "Ha a jövőben mobiltelefon szolgáltatásra lesz szükségem, ezt a szolgáltatót keresném fel először”. A négy állítás átlaga képezi a végső lojalitás változót.

A mérési skálák esetében a Cronbach alfák 0,786 és 0,915 között vannak (lemorzsolódás: 0,786, elégedettség: 0,823, lojalitás: 0,915).

\subsubsection{BELSÖ ÉS KÜLSÖ ÉRVÉNYESSÉG TESZTELÉSE}

Blodgett és szerzőtársai (1997) ajánlásainak megfelelően, a belső és külső érvényességet egy különálló kvantitatív kutatásban teszteltük, függetlenül a fő kísérlettől, melynek eredménye, hogy a változók hatásosak, szignifikáns különbséget mutatva az egyes forgatókönyvek között az összes feltétel esetében $(\mathrm{N}=166)$.

A belső érvényesség kidolgozásában a következő definíciókat alkalmaztuk: a disztributív igazságosság a kimenetel észlelt igazságossága (Blodgett et al., 1997), a procedurális igazságosság az irányelvek, folyamatok és kimenethez vezető kritériumok észlelt igazságossága (Thibaut \& Walker, 1975; Lind \& Tyler, 1988; Alexander \& Ruderman, 1987), és az interakciós igazságosság a folyamat bánásmódját fejezi ki (Bies \& Moag, 1986; Bies \& Shapiro, 1987).

A három független változó esetében a belső érvényességet a következő állításokkal teszteltük (Blodgett et al., 1997): a disztributív igazságosság esetében: "Mindent figyelembe véve, a szolgáltató ajánlata fair volt", "Nem kaptam meg, amit megérdemeltem volna" (fordított skála), és “A körülményeket figyelembe véve, úgy érzem, hogy a szolgáltató egy megfelelö ajánlatot adott számomra", ahol $M$ (disztributív igazságosság)= 4,06 vs. $M$ (nincs disztributiv igazságosság) $=3,42, F(1,164)=14,788, \mathrm{p}<0,000$. A procedurális igazságosság mérésére is három elemü skálát használtunk: "A szolgáltatáskivezetést időben kezelte a szolgáltató”, “A szolgáltatáskivezetés helyzetének kezelése nem történt meg olyan gyorsan, mint ahogyan az elvárható lett volna" (fordított skála), és “A szolgáltatáskivezetés folyamata ügyfélbarát volt", ahol $M$ (procedurális igazságosság)= 3,56 vs. $M$ (nincs procedurális igazságosság $)=2,96, F(1,164)=20,009, \mathrm{p}<0,000$. További három állítást használtunk az interakciós igazságosság mérésére: “Udvariasan, tisztelettel bántak velem”, “Úgy tủnt, hogy az alkalmazottak odafigyelnek rám”, “Az alkalmazottaknak inkább negatív volt az attitüdje” (fordított skála), "Úgy érzem, hogy gorombán bántak velem” (fordított skála), ahol $M$ (interakciós igazságosság) $=3,64$ vs. $M$ (nincs interakciós igazságosság) $=2,05, F(1,164)=$ 
64,642, p<0,000. A kidolgozott forgatókönyvek tehát megfelelően jelenítik meg a független változókat.

Külső érvényesség szempontjából a forgatókönyvek realisztikusságát is ellenőriztük a következő két állítással: "Úgy érzem, hogy ez az eset realisztikus" és "Ez az eset megtörténhet a mindennapi életben”, ahol az állítások átlagértékei egy 5 fokozatú Likertskálán 2,47 és 3,11 között vannak a 8 forgatókönyv esetében, azt sugallva, hogy a forgatókönyvek inkább realisztikusak.

\subsubsection{EREDMÉNYEK}

A disztributív, procedurális és interakciós igazságosság lemorzsolódásra, elégedettségre, és lojalitásra gyakorolt hatását faktoriális ANOVA-val teszteltük ${ }^{6}$ (Field, 2003), SPSS szoftver segítségével (Mitev \& Sajtos, 2007).

A nyolc forgatókönyv átlagértékeit a 8. táblázat foglalja össze.

Disztributív igazságosság (0: nincs disztributív igazságosság; 1: van disztribúciós igazságosság)

A disztributív igazságosság esetében minden függő változó a hipotéziseknek megfelelően változik: a disztributív igazságosság csökkenti a lemorzsolódást, és növeli az elégedettséget és lojalitást. Vagyis a H4-et elfogadjuk.

Procedurális igazságosság (0: nincs procedurális igazságosság; 1: van procedurális igazságosság)

Meglepő módon a procedurális igazságosság hatása nem szignifikáns. A forgatókönyvek szerint abban az esetben teljesült a procedurális igazságosság feltétele, ha a szolgáltató lépett kapcsolatba az ügyféllel és ezért az ügyfélnek nem kellett felhívnia a szolgáltatót és hosszasan várnia, valamint nem teljesült, amennyiben az ügyfélnek kellett felhívnia a szolgáltatót a szolgáltatáskivezetésről szóló tájékoztatás összetettsége miatt, többszöri felkeresés és hosszas várakozás után érte csak el a szolgáltatót.

Az eredmények szerint azonban a két változat között nincs szignifikáns különbség, hiszen valószínűleg a szolgáltatótól érkező hívás, illetve az ügyfél által indított hívás egyaránt kellemetlen lehet az ügyfél számára, a procedurális igazságosság esetén teljesülő jóval kedvezőbb körülmények ellenére. Ezt részben az operacionalizálás problémái okozhatják, a procedurális igazságosság hatását vélhetőleg csak részben sikerült megragadni, annak ellenére, hogy a hívás váratlansága mellett a hosszú várakozási idő és többszöri próbálkozás is

\footnotetext{
${ }^{6}$ Az elemzés során 5\%-os szignifikancia szintet használunk.
} 
megjelent a forgatókönyvekben, a procedurális igazságosság definíciójának megfelelően. Másodsorban, a procedurális igazságosság teljesülése sem feltétlenül pozitív élmény az ügyfél számára: a szolgáltatótól érkező hívás is lehet zavaró, például az észlelt kontroll elvesztése vagy a hívás nem megfelelő időzítése miatt. Vagyis mindezek alapján a H5-öt elutasítjuk.

Interakciós igazságosság (0: nincs interakciós igazságosság; 1: van interakciós igazságosság)

A disztributív igazságossághoz hasonlóan, az interakciós igazságosság függő változókra gyakorolt hatása megfelel hipotéziseknek: az interakciós igazságosság csökkenti a lemorzsolódást, és növeli az elégedettséget és lojalitást. Vagyis a H6-ot elfogadjuk.

\section{8. táblázat: A függő változók átlagértékei a független változók szerint képzett}

csoportokban (a szignifikáns átlagértékek vastag kiemeléssel szerepelnek)

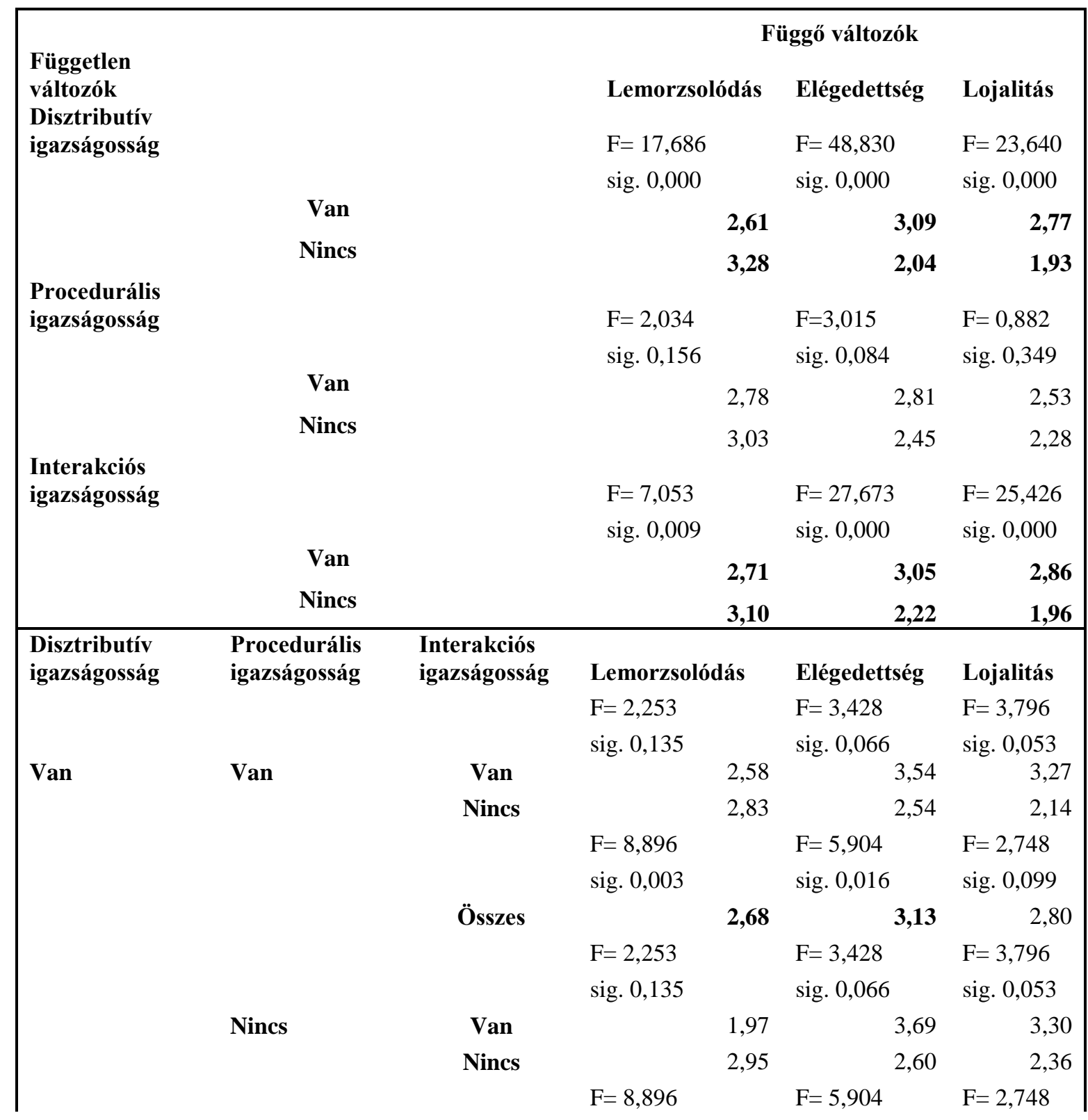




\begin{tabular}{|c|c|c|c|c|c|c|}
\hline & & & sig. 0,003 & & sig. 0,016 & sig. 0,099 \\
\hline & & Összes & & 2,54 & 3,05 & 2,75 \\
\hline & & & $\mathrm{F}=1,713$ & & $\mathrm{~F}=2,933$ & $\mathrm{~F}=0,911$ \\
\hline & & & sig. 0,192 & & sig. 0,089 & sig. 0,341 \\
\hline & Összes & Van & & 2,33 & 3,60 & 3,28 \\
\hline & & Nincs & & 2,90 & 2,57 & 2,27 \\
\hline & & & $\begin{array}{l}F=2,253 \\
\text { sig. } 0,135\end{array}$ & & $\begin{array}{l}F=3,428 \\
\text { sig. } 0,066\end{array}$ & $\begin{array}{l}F=3,796 \\
\text { sig. } 0,053\end{array}$ \\
\hline \multirow[t]{18}{*}{ Nincs } & Van & Van & & 2,74 & 2,32 & 2,21 \\
\hline & & Nincs & & 3,05 & 2,39 & 2,09 \\
\hline & & & $\mathrm{F}=8,896$ & & $F=5,904$ & $\mathrm{~F}=2,748$ \\
\hline & & & sig. 0,003 & & sig. 0,016 & sig. 0,099 \\
\hline & & Összes & & 2,93 & 2,36 & 2,14 \\
\hline & & & $\mathrm{F}=2,253$ & & $\mathrm{~F}=3,428$ & $\mathrm{~F}=3,796$ \\
\hline & & & sig. 0,135 & & sig. 0,066 & sig. 0,053 \\
\hline & Nincs & Van & & 3,52 & 2,29 & 2,35 \\
\hline & & Nines & & 3,63 & 1,16 & 1,06 \\
\hline & & & $\mathrm{F}=8,896$ & & $\mathrm{~F}=5,904$ & $\mathrm{~F}=2,748$ \\
\hline & & & sig. 0,003 & & sig. 0,016 & sig. 0,099 \\
\hline & & Összes & & 3,57 & 1,77 & 1,75 \\
\hline & & & $\mathrm{F}=1,713$ & & $\mathrm{~F}=2,933$ & $\mathrm{~F}=0,911$ \\
\hline & & & sig. 0,192 & & sig. 0,089 & sig. 0,341 \\
\hline & Összes & Van & & 3,23 & 2,30 & 2,30 \\
\hline & & Nincs & & 3,33 & 1,80 & 1,60 \\
\hline & & & $\mathrm{F}=0,760$ & & $\mathrm{~F}=4,531$ & $\mathrm{~F}=2,026$ \\
\hline & & & sig. 0,385 & & sig. 0,035 & sig. 0,156 \\
\hline \multirow[t]{6}{*}{ Összes } & Van & Van & & 3,63 & 3,15 & 2,93 \\
\hline & & Nincs & & 2,94 & 2,46 & 2,12 \\
\hline & & & $\mathrm{F}=0,760$ & & $\mathrm{~F}=4,531$ & $\mathrm{~F}=2,026$ \\
\hline & & & sig. 0,385 & & sig. 0,035 & sig. 0,156 \\
\hline & Nincs & Van & & 2,80 & 2,94 & 2,79 \\
\hline & & Nincs & & 3,24 & 2,00 & 1,81 \\
\hline
\end{tabular}

\section{Forrás: saját szerkesztés}

A disztributív, procedurális és interakciós igazság közötti interakciók

A főhatásokat kettős interakciók jellemzik, amelyeket a 14. ábrán szemléltetünk. Először is, az elégedettség esetében azt láthatjuk, hogy a disztributív igazságosság mindig növeli az elégedettséget, és az interakciós igazságosság is jellemzően magasabb elégedettséghez vezet.

Másodsorban, a procedurális és interakciós igazságosság interakciója az elégedettség esetében azt mutatja, hogy az interakciós igazságosság ugyan mindig növeli az elégedettség szintjét a procedurális igazságosságtól függetlenül, mégis magasabb elégedettség érhető el a procedurális igazságosság hiányában (az ügyfél hívja fel a szolgáltatót, többszöri próbálkozás 
és hosszas várakozási idő után éri el a szolgáltatót). Ez is hangsúlyozza az ügyfél által indított hívás jelentőségét.

Harmadsorban, a disztribúciós igazságosság hiányában a procedurális igazságosság csökkenti a lemorzsolódást és növeli az elégedettséget, míg a disztribúciós igazságosság jelenlétében a procedurális igazságosság hatása ezzel ellentétes a két változó esetében.

Mindezek az eredmények alapján a H7-et részben elfogadjuk.

Tehát a hipotéziseinket részben igazolni tudtuk: a föhatások tekintetében, a disztributív és interakciós igazságosság csökkentik a lemorzsolódást, és növelik az elégedettséget és lojalitást várakozásinknak megfelelően, a procedurális igazságosságnak pedig nem szignifikáns a hatása. Az interakciók tekintetében, az interakciós igazságosság egyfajta kompenzáló hatással bír a procedurális igazságosság esetében, hozzátéve, hogy összességében magasabb elégedettségi szint érhető el az ügyfél által indított hívással. Ehhez hasonlóképpen, a procedurális igazságosság képes részben kompenzálni a disztribúciós igazságosság hiányát, vagyis egy kedvezőtlenebb ajánlat lemorzsolódásra és lojalitásra gyakorolt hatásának nagysága csökkenthető egy, az ügyfél számára problémáktól mentes szolgáltatáskivezetési folyamattal.

Ezek az eredmények tehát azt jelentik, hogy a H4-et és H6-ot elfogadjuk, a H5-öt elutasítjuk és a H7-et részben elfogadjuk.

14. ábra: A disztributív, procedurális és interakciós igazságosság interakciói ${ }^{7}$
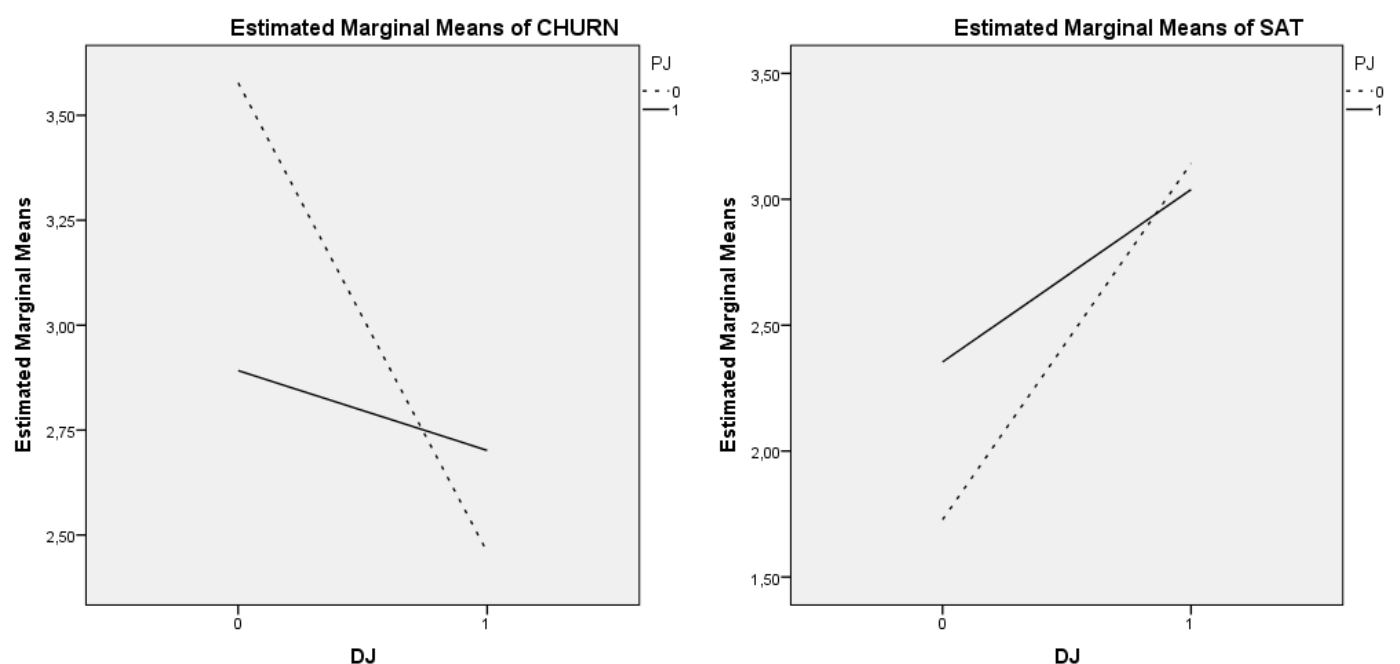

DJ

7 Jelmagyarázat: $\mathrm{DJ}=$ disztribúciós igazságosság, $\mathrm{PJ}=$ procedurális igazságosság, $\mathrm{IJ}=$ interakciós igazságosság, $\mathrm{SAT}=$ elégedettség, $\mathrm{LOY}=$ lojalitás, $\mathrm{CHURN}=$ lemorzsolódás 


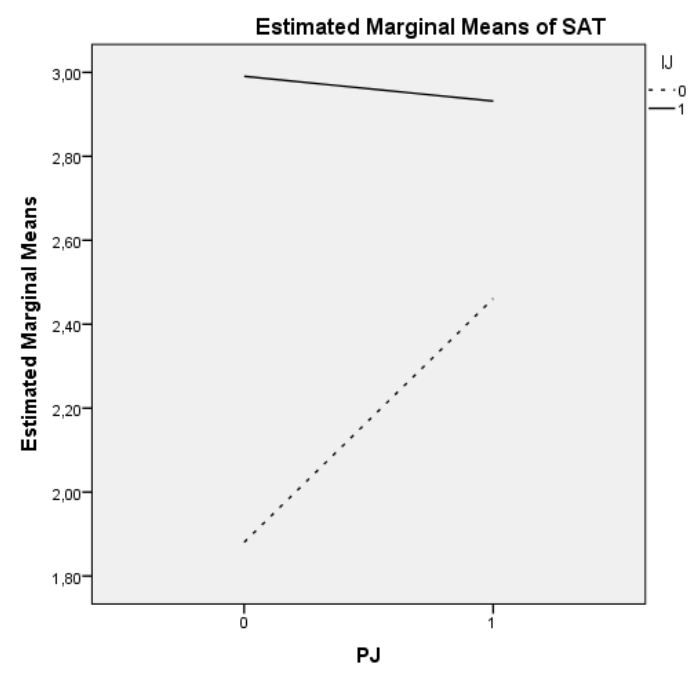

Forrás: saját szerkesztés

A 2. tanulmány eredményei szerint a procedurális igazságosság hatása nem felel meg előzetes várakozásainknak: a szolgáltató által indított hívás ronthatja a szolgáltatáskivezetés ügyfél reakcióit valószínűleg azért, mert főként azok lennének képesek értékelni a szolgáltató proaktivitását, akik már egy ügyfélszolgálati hívással kapcsolatban negatív élményt tapasztaltak korábban (pl. hosszú várakozási idő, bonyolult IVR -interacive voice responserendszer, stb.). Ezen kívül, a szolgáltató által indított hívás kellemetlen lehet az ügyfél számára, egy általa indított hívással szemben, az észlelt kontroll elvesztése, az ügyfél napi tevékenységében való megzavarása, a hívás rossz időzítése, stb. miatt. Másodsorban, az igazságosság dimenziói közül a disztribúciós és interakciós igazságosságnak mindig van hatása az ügyfélreakciókra, azonban a procedurális igazságosság inkább az ezekkel való interakciókat határozza meg.

Gyakorlati szempontból érdekes eredmény, hogy egy kedvezőtlenebb ajánlat esetén a procedurális igazságosság részben képes az ajánlat lemorzsolódásra és elégedettségre gyakorolt hatását kompenzálni, és hasonlóképpen, az interakciós igazságosság képes a procedurális igazságosság hiányát kompenzálni. Vagyis a szolgáltatók az új ajánlat kedvezőtlenebb feltételeit kompenzálhatják egy összességében problémamentes folyamattal az ügyfél számára (sebesség, amely a folyamat időigényét, a szolgáltató elérhetőségét és a szolgáltatáskivezetési folyamat kényelmi szintjét fejezi ki, valamint az észlelt igazságosságot és várakozási időt jelenti). Emellett lényeges szempont, hogy a szolgáltató proaktivitása alacsonyabb elégedettséghez vezet, az ügyfél által indított hívással összehasonlítva, amely felveti az időpontfoglalás lehetőségének szükségességét. Összességében tehát a szolgáltató elérhetősége, és a teljes szolgáltatáskivezetési folyamat időigénye, és okozott kényelmetlensége befolyásolja az ügyfél elégedettségi szintjét és lemorzsolódási 
valószínűségét. Fontos megjegyezni, hogy az ügyfélnek kellene kezdeményeznie a hívást, az észlelt kontroll szerepe miatt, amely kiküszöbölhető időpontfoglalási rendszer használatával.

Vagyis a 2. tanulmány alapján a hipotéziseink tekintetében a következőket állapíthatjuk meg:

4. hipotézis: A disztributív igazságosság csökkenti a lemorzsolódást, és növeli az elégedettséget és lojalitást szolgáltatáskivezetés esetén.- elfogadva (8. táblázat)

5. hipotézis: A procedurális igazságosság csökkenti a lemorzsolódást, és növeli az elégedettséget és lojalitást szolgáltatáskivezetés esetén.- elutasitva (8. táblázat)

6. hipotézis: Az interakciós igazságosság csökkenti a lemorzsolódást, és növeli az elégedettséget és lojalitást szolgáltatáskivezetés esetén.- elfogadva (8. táblázat)

7. hipotézis: A disztributív, procedurális és interakciós igazságosság között interakciós hatás figyelhetö meg szolgáltatáskivezetés esetén.- részben elfogadva (8. táblázat)

\subsection{TANULMÁNY: AdATBÁZIS ELEMZÉs: AZ ÜGYFÉl ÉS SZOLGÁlTATÁSKIVEZETÉS TULAJDONSAGGAINAK A SZOLGÁLTATÁSKIVEZETÉS KIMENETELÉRE ÉS A SZOLGÁLTATÁSKIVEZETÉST KÖVETÖ HASZNÁLAT INTENZITÁSÁRA GYAKOROLT HATÁSA}

A szolgáltatásportfóliók gyors innovációja a versenyelőny alapvető feltétele. Ebben az értelemben a szolgáltatáskivezetés a portfólió megújítási eszközének tekinthető, amely során a vállalatok elsődleges stratégiai prioritása az ügyfél megtartása. Szolgáltatáskivezetés során a lemorzsolódás jóval magasabb a szolgáltatási szektor átlagos lemorzsolódási rátájánál, ezáltal az ügyfélmegtartás a szolgáltatáskivezetés sikerességének kulcsaként tekinthető. A tanulmány célja, hogy meghatározza azokat a tényezőket, amelyek az ügyfélmegtartás növelését befolyásolják szolgáltatáskivezetés esetén.

Egy telekommunikációs szolgáltató 10065 ügyfél -szolgáltatáskivezetést három hónappal megelőző és azt követő szolgáltatáshasználati- adatai, valamint szerződéseinek információit tartalmazó adatbázisa segítségével különböztetjük meg a lemorzsolódást erősen, illetve gyengén befolyásoló tényezőket. A kutatás során használt modellt Heckman- féle korrekciós eljárással (Heckman sample selection) teszteltük. Eredményeink azt mutatják, hogy szolgáltatáskivezetés esetén az árcsökkenés, az ügyfél szerződésének időtartama és az interakciós intenzitás növelik az ügyfélmegtartás valószínüségét, valamint azok esetében, akik a szolgáltatónál maradnak szolgáltatáskivezetést követően, a magasabb új havidíj növeli az ügyfél szolgáltatáshasználatának intenzitását. 
A kutatás hozzájárul az ügyfélmegtartás és szolgáltatáskivezetés szakirodalmához, és gyakorlati ajánlásokat fogalmaz meg a döntéshozók számára.

A 3. tanulmányban a következő hipotéziseket teszteljük:

8. hipotézis: A szolgáltatáskivezetés esetén jelentkező lemorzsolódás magasabb a normál lemorzsolódáshoz képest.

9. hipotézis: Az áremelkedés csökkenti az ügyfélmegtartás valószinüségét szolgáltatáskivezetés esetén, árcsökkenéssel összehasonlítva.

10. hipotézis: Az áremelkedés növeli a szolgáltatáskivezetést követö használat mértékét árcsökkenéssel összehasonlitva.

11. hipotézis: A hosszabb szerzödéses kapcsolat a szolgáltatóval növeli az ügyfélmegtartás valószínüségét szolgáltatáskivezetés esetén, a rövidebb szerzödéses kapcsolattal összehasonlitva.

12. hipotézis: A váltási korlátok növelik az ügyfélmegtartás valószinüségét szolgáltatáskivezetés esetén, a váltási korlátok hiányával összehasonlitva.

13. hipotézis: Az interakciós intenzitás magasabb szintje növeli az ügyfélmegtartást szolgáltatáskivezetés esetén, az interakciós intenzitás alacsonyabb szintjével összehasonlítva.

14. hipotézis: Az interakciós intenzitás magasabb szintje növeli a szolglátatáskivezetést követö alacsonyabb használat valószinüségét, az interakciós intenzitás alacsonyabb szintjével összehasonlitva.

\subsubsection{MÓDSZERTAN}

Mivel a függő változó (lemorzsolódás) Dummy változó, ezért probit vagy logit regresszió lehet alkalmas a modell becslésére. Esetünkben azonban a szelekciós torzítás miatt nem alkalmazhatunk normál probit vagy logit regressziót. Ennek oka a következő: kutatásunkban a lemorzsolódás modellezése mellett a fogyasztói magatartás különbségeit vizsgáljuk a szolgáltatáskivezetés előtt és után. Miután a modell első részében megbecsüljük a lemorzsolódás valószínűségét, a második részben kizárólag azoknak az ügyfeleknek vizsgáljuk a szolgáltatás-használati szokásainak a változását, akik nem hagyták el a szolgáltatót a kivezetést követően. Ez a kiválasztás viszont értelemszerüen nem véletlenszerü, ezért fellép a szelekciós torzítás veszélye.

Szelekciós probléma kezelésére a szakirodalom számos módszertant használ. Az egyik legismertebb a kontrollált kísérlet, amelyet többnyire egészségügyben szoktak alkalmazni. Esetünkben ez a módszer nem használható, hiszen adatbázis elemzésről, nem kísérleti 
módszertanról van szó. További eljárások közé tartozik a diff-in-diff (DID) módszer (Krueger \& Card, 1994), amely azonban feltételezi, hogy ismerjük azokat az ügyfeleket, akiket a szolgáltatáskivezetés nem érintett, és ebben az esetben a kontrollcsoport és a szolgáltatáskivezetés szempontjából érintett csoport azonosan viselkedik (Abadie, 2005). Esetünkben ez a módszer szintén nem használható, hiszen nem ismerjük azokat, akik a kivezetésben nem érintettek.

A harmadik gyakori módszer az instrumentális változók használata (Arellano \& Bover, 1995). Az elemzésünk esetében nem volt megfelelő instrumentális változó, amely megfelelően elörejelzi a lemorzsolódást, így ezt az eljárást nem tudtuk használni. A Heckman- féle korrekciós eljárást olyan esetekben ajánlják, amikor a többi módszer érdemben nem használható. Így a Heckman- féle korrekciós eljárást választottuk a probléma kezelésére (Heckman, 1979; Gronau, 1974; Lewis, 1974) ${ }^{8}$.

A modellben használt változók a következőek:

\section{Függő változók:}

-Szolgáltatáshasználati intenzitás változása (MINDIFF): kivezetés előtti és utáni beszélgetések hosszának percekben mért különbsége;

- Lemorzsolódás (CHURN): értéke 0 , ha az ügyfél szolgáltatót váltott a szolgáltatáskivezetést követően, egyébként 1 .

\section{Független változók:}

- Áremelkedés (logMFDIFF): régi és új havidíj különbségének logaritmusa $(\log$ MFDIFF);

- Szerződés időtartama (TENURE): a szerződés kezdete és vége között eltelt idő, napban mérve;

- Váltási korlátok (CONTRACT): értéke 1, ha az ügyfél a szolgáltatáskivezetés idején hüségidővel rendelkezik, egyébként 0 ;

- Interakciós intenzitás (CC CALLS): az ügyfélszolgálatra beérkező/indított hívások száma az ügyfél szerződésének kezdetétől;

- Interakciós változóhoz tartozó dummy változó (D_CC_CALLS): értéke 1, ha a CC_CALLS változó értéke ismert, egyébként 0 .

\footnotetext{
${ }^{8}$ A módszertan ismertetése az 6 . függelékben található.
} 


\section{Kovariánsok:}

- Használati intenzitás a kivezetés előtt (BEFORE_USAGE_MINUTES):

kivezetés előtti beszélgetés percben mérve;

- Elégedettség (NPS_CC): az ügyfélszolgálattal történt beszélgetést követően az ügyfél által adott elégedettségi érték, amelynek értéke 1 és 10 között van;

- Elégedettséghez tartozó dummy változó (D_NPS_CC): értéke 1, ha az NPS_CC változó értéke ismert, egyébként 0 .

Az elméleti konstrukciók alapján operacionalizáljuk a változók közötti hatásokat. A kétlépcsős Heckman- féle korrekciós modellben a lemorzsolódást (CHURN) használjuk függő változóként az első lépésben, és a szolgáltatáshasználati intenzitás változását, a régi és új havidíj különbségének logaritmusának segítségével (logMINDIFF), a másodikban. A regressziós egyenlet koefficiensei megmutatják, hogy melyik változó(k) befolyásolják szignifikánsan a lemorzsolódást, majd a szelekciós egyenlet vizsgálja a szolgáltatáshasználat alakulását szolgáltatáskivezetést követően.

A független változók közötti kapcsolatot és a hozzájuk kapcsolódó hat hipotézist a 15. ábrán mutatjuk be.

\section{5. ábra: A változók közti feltételezett kapcsolatok}

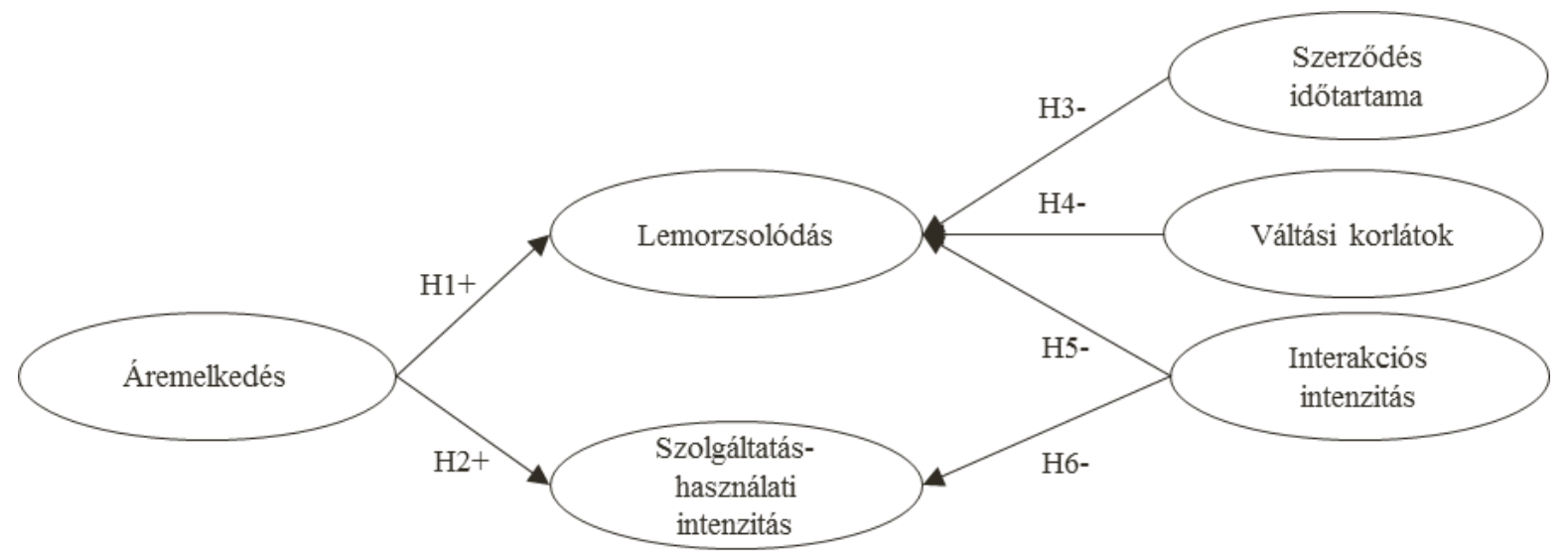

\section{Forrás: Saját szerkesztés}

Tehát a Heckman- féle korrekciós modell a következő:

MINDIFF $=\beta_{0}+\beta_{1} \log M F D I F F+\beta_{2} C C \_C A L L S+\beta_{3} D \_C C \_C A L L S+$

$\beta_{4} B E F O R E \_U S A G E \_M I N U T E S+\beta_{5} N P S \_C C+\beta_{6} D \_N P S \_C C+\mathrm{u}_{1}$ (regressziós egyenlet)

és a MINDIFF csak akkor értelmezett a regressziós egyenletben, ha a szelekciós egyenletben: 
CHURN $=1=\gamma_{0}+\gamma_{1} \log M F D I F F+\gamma_{2}$ TENURE $+\gamma_{3} C O N T R A C T+\gamma_{4} C C_{-} C A L L S+$ $\gamma_{5} D \_C C \_C A L L S+\gamma_{6} B E F O R E \_U S A G E \_M I N U T E S+\gamma_{7} N P S \_C C+\gamma_{8} D \_N P S \_C C+\mathrm{u}_{2}$

(szelekciós egyenlet), ahol $\mathrm{u}_{1} \sim \mathrm{N}(0, \sigma), \mathrm{u}_{2} \sim \mathrm{N}(0,1)$ és corr $\left(\mathrm{u}_{1}, \mathrm{u}_{2}\right)=\rho$.

A szakirodalom alapján azt várjuk, hogy a régi és új havidíj különbségének logaritmusa (logMFDIFF), a szerződés időtartama (TENURE), a váltási korlátok (CONTRACT) és az interakciós intenzitás (CC_CALLS) változók csökkentik a lemorzsolódást (CHURN). Ezek mellett kovariánsokat használunk, hogy finomítsuk a függő és független változók közötti hatást, de ezekkel kapcsolatban nem fogalmazunk meg hipotéziseket. A modell második lépésében a kivezetés előtti és utáni használati intenzitás változását (MINDIFF) használjuk, hogy elemezzük a használati intenzitásban bekövetkező változásokat azok esetében, akik a szolgáltatónál maradtak a kivezetést követően.

\subsubsection{ADAT ÉS ADATMINÖSÉG}

Az adatok egy telekommunikációs szolgáltató egyik legnagyobb, 2012-2013-as tarifakivezetési projektjéből származnak. A kutatást egy hazai telekommunikációs vállalat adatbázisán végeztük el. A minta 25 kivezetésre került lakossági, valamint 62 SOHO (small office- home office, kisvállalati szegmens) mobil szolgáltatás csomagot tartalmaz (vezetékes és egyéb szolgáltatásokat nem), összesen 10065 ügyfél 3 hónappal a szolgáltatáskivezetést megelőző és azt követő szolgáltatáshasználati adatait, valamint szerződéssel kapcsolatos információkat. A 10065 ügyfél közül 1585-en hagyták el a vállalatot, amely 15,76\%-os lemorzsolódásnak felel meg, vagyis jóval magasabb a 2\%-os nemzetközi iparági átlagnál (ClintWorld GmbH., 2013).

$\mathrm{Az}$ adatok minőségi problémája miatt az adatbázis egy részét módosítanunk kellett, hogy a kivezetésből adódó árszintek változására vonatkozóan is eredményeket kaphassunk.

Az adatbázis a nem lemorzsolódott ügyfelek esetében hiányos. Ha azt feltételezzük, hogy az ügyfél nem hagyta el a szolgáltatót a szolgáltatáskivezetést követően, akkor rendelkezniük kell egy új havidíjjal, amelynek összege ismert kell, hogy legyen. Ennek ellenére, bizonyos esetekben hiányoznak ezek az adatok. A vállalat sajnos nem tudta reprodukálni a helyes adatokat, mivel az adatbázis 2012-13-as, és ilyen struktúrában ezek az adatok már nem elérhetőek.

A probléma kezelése érdekében úgy döntöttünk, hogy a nem lemorzsolódott ügyfelek esetében az új, kivezetés utáni havidíjat a következőképpen kalkuláljuk: elemeztük a kivezetés utáni havidíjak tipikus értékeit a régi havidíjak típusai szerint, és a hiányzó új havidíjat felülírtuk ezekben az esetekben az új havidíjak, adott havidíj csoporthoz tartozó 
móduszával. Ezt követően ezeket az új értékeket használtuk a havidíj különbség logaritmusának számításához. Az adatbázis többi részében nem találtunk hibát.

A változtatások ellenére a havidíjon felüli költések, az ún. out-of-bundle usage, nem elérhetőek az adatbázisban, ezért cikkünk során kizárólag a havidíjban bekövetkezett változásokkal számolunk.

\subsubsection{EREDMÉNYEK}

A választott módszertan, a Heckman- féle korrekciós eljárás az $\mathrm{R}$ programban a sampleselection csomaggal elérhető, Stata- ban pedig a heckman paranccsal. Elemzésünkhöz a Stata 13 programot használtuk.

A modell lefuttatása előtt a multikollinearitás, vagyis a magyarázóváltozók együttmozgását (Kovács, 2008) teszteljük. A modell első lépésében használt változókkal lineáris regressziót futtattunk, hogy a VIF (Variance Inflation Factor- Varianciainflációs tényezö) paramétert meg tudjuk határozni, amely a multikollinearitás súlyosságát mutatja meg (Craney \& Surles, 2002). Mivel a Heckman eljárás nem lineáris, ezért volt szükség erre a kiegészítő lineáris regresszióra (7. függelék). A VIF becslés szerint az összes érték 10 alatt van (8. függelék), amely arra utal, hogy nincs súlyos multikollinearitás a változók között (O’brien, 2007). Emellett a korrelációs mátrixot is vizsgáltuk (9. függelék), amely szintén nem mutatott jelentős korrelációt a magyarázó változók között.

A Heckman- féle korrekciós modell eredményei az 9. táblázatban láthatóak. A Heckman- féle szelekciós modell első lépése ${ }^{9}$ azt mutatja, hogy a régi és új havidíj különbségének logaritmusa, (logMFDIFF), a szerződés időtartama (TENURE) és az interakciós intenzitás (CC_CALLS) növelik az ügyfél-megtartás valószínűségét szolgáltatáskivezetést követően, a 9., 11. és 13. hipotéziseinknek megfelelően, azonban a váltási korlátoknak (CONTRACT) nincs szignifikáns hatásuk, vagyis a 12. hipotézist elutasítjuk. A kovariánsok közül a kivezetés elötti használati intenzitás (BEFORE_USAGE_MINUTES) növeli az ügyfél-megtartásának valószínűségét, míg az elégedettség (NPS_CC) nem szignifikáns.

A modell második lépésében azt vizsgáljuk, hogy azok esetében, akik a szolgáltatónál maradtak, a kivezetés megváltoztatta-e a szolgáltatás-használati intenzitásukat. Az eredmények azt mutatják, hogy a régi és új havidíj különbségének logaritmusa (logMFDIFF) és a kivezetés előtti használati intenzitás (BEFORE_USAGE_MINUTES) növeli a kivezetés

\footnotetext{
${ }^{9}$ Az elemzés során 1\%-os szignifikancia szintet alkalmazunk.
} 
utáni használati intenzitást, míg az interakciós intenzitás (CC_CALLS) és az elégedettség (NPS_CC) nem szignifikáns, vagyis a 14. hipotézist elutasítjuk. Ez azt jelenti, hogy a 10. hipotézist alátámasztják az eredmények, hiszen az áremelkedés (magasabb új havidíj) növeli a szolgáltatáskivezetést követő használat intenzitását.

9. táblázat: A Heckman- féle korrekciós modell eredményei: 1. modell ( $\mathrm{N}=7766$, a szignifikáns értékek vastag kiemeléssel szerepelnek)

\begin{tabular}{l|l|l|l} 
Függő változó & Együttható & Standard hiba & $P>z$
\end{tabular}

2. lépés: A nem lemorzsolódott ügyfelek fogyasztói szokásainak elemzése szolgáltatáskivezetés esetén

\begin{tabular}{l|c|c|c} 
Függő változó: logMINDIFF & & \\
logMFDIFF & $\mathbf{0 , 2 5 1 5 0 1 9}$ & $\mathbf{0 , 0 4 1 3 1 0 2}$ & $\mathbf{0 , 0 0 0}$ \\
\hline CC_CALLS & $-0,0145473$ & 0,0075202 & 0,053 \\
\hline D_CC_CALLS & 0,0825613 & 0,0601285 & 0,170 \\
\hline BEFORE_USAGE_MINUTES & $\mathbf{0 , 0 0 0 0 1 8 0}$ & $\mathbf{1 , 2 8 e - 0 6}$ & $\mathbf{0 , 0 0 0}$ \\
\hline NPS_CC & 0,0271769 & 0,0258020 & 0,292 \\
\hline D_NPS_CC & 0,3731505 & 0,1677520 & 0,026 \\
\hline Konstans & $\mathbf{- 1 , 4 3 3 9 5 8 0}$ & $\mathbf{0 , 1 7 3 6 2 4 0}$ & $\mathbf{0 , 0 0 0}$ \\
\hline
\end{tabular}

1. lépés: A lemorzsolódás becslése szolgáltatáskivezetés esetén

\begin{tabular}{l|c|c|c} 
Függő változó: CHURN & & & \\
logMFDIFF & $-\mathbf{0 , 1 0 6 3 1 3 6}$ & $\mathbf{0 , 0 3 7 4 2 8 6}$ & $\mathbf{0 , 0 0 5}$ \\
\hline TENURE & $\mathbf{0 , 0 0 0 3 1 4 7}$ & $\mathbf{0 , 0 0 0 0 4 8 4}$ & $\mathbf{0 , 0 0 0}$ \\
\hline CONTRACT & $-0,0282765$ & 0,0543901 & 0,603 \\
\hline CC_CALLS & $\mathbf{0 , 1 2 3 4 8 8 7}$ & $\mathbf{0 , 0 2 4 0 5 7 7}$ & $\mathbf{0 , 0 0 0}$ \\
\hline D_CC_CALLS & $\mathbf{- 0 , 3 3 9 0 4 6 4}$ & $\mathbf{0 , 0 7 3 6 8 5 4}$ & $\mathbf{0 , 0 0 0}$ \\
\hline BEFORE_USAGE_MINUTES & $\mathbf{6 , 0 0 e - 0 6}$ & $\mathbf{1 , 2 3 e - 0 6}$ & $\mathbf{0 , 0 0 0}$ \\
\hline NPS_CC & $-0,0332769$ & 0,0410659 & 0,418 \\
\hline D_NPS_CC & $-0,5202374$ & 0,3178663 & 0,102 \\
\hline Konstans & $\mathbf{1 , 3 2 6 7 6 1 0}$ & $\mathbf{0 , 3 3 9 1 4 2 3}$ & $\mathbf{0 , 0 0 0}$ \\
\hline ath $\rho$ & 0,5020116 & 0,0552090 & 0,000 \\
\hline $\ln \sigma$ & 0,5172867 & 0,0124170 & 0,000 \\
\hline$\rho$ & 0,4636977 & 0,0433382 & \\
\hline
\end{tabular}




\begin{tabular}{l|c|c|c}
\hline$\sigma$ & 1,6774700 & 0,0208291 & \\
\hline$\lambda$ & 0,7778390 & 0,0797093 & \\
\hline LR-teszt független egyenletekre & $\chi^{2}(1)=32,00$ & 0,0000 \\
$(\rho=0)$ & 7766 & \\
\hline Megfigyelések száma (darab) & 1502 & \\
\hline Cenzorált megfigyelések száma & & \\
$($ darab) & 6264 & \\
\hline Nem cenzorált megfigyelések & 269,64 \\
száma (darab) & $-15425,09$ \\
\hline Wald $\chi^{2}$ (10) & 0,0000 \\
\hline Log-likelihood & \multicolumn{2}{|c}{} \\
\hline Prob > $\chi^{2}$ & \multicolumn{2}{|c}{} \\
\hline
\end{tabular}

\section{Forrás: saját szerkesztés}

Mivel a Heckman- féle korrekciós eljárás nem jelenít meg a kétlépcsős eljárás végén a modell jóságával kapcsolatban információt, ezért az $\mathrm{R}^{2}$ mutatót manuálisan számítottuk ki. Erre több eljárás is létezik, pl. a Nagelkerke vagy a McFadden $\mathrm{R}^{2}$ (Smith \& McKenna, 2013). A Nagelkerke $\mathrm{R}^{2}$ rendszerint túlbecsül, ezért a $M c F a d d e n ~ \mathrm{R}^{2}$-et választottuk a modell jóságának meghatározására. Ez az érték azt mutatja meg, hogy a modell az üres modell és a szaturált modell közötti log-likelihoodban kifejezett távolság hány százalékát tette meg az üres modelltől indulva. Ehhez szükség van a csak konstanst tartalmazó modellre (10. függelék).

A McFadden $\mathrm{R}^{2}$ az 1 . modell esetén tehát a következő:

$$
\frac{(-2(-20529,41))-(-2(-15425,09)}{-2(-20529,41)}=\frac{41058,82-30850,18}{41058,82}=0,2486 .
$$

Ez azt jelenti, hogy a modell a potenciális javulás 24, 86\%-át fejezi ki.

A modell javítására backward modelleket futtattunk, vagyis lépésenként kivettük azt a változót, amelynek az inszignifikanciája a legmagasabb volt, utána a következő legmagasabb inszignifikanciával rendelkező változót és így tovább. Mivel a Heckman- féle korrekciós eljárás nem futtat forward vagy backward modellt, ezért manuálisan végeztük el a modellek tesztelését. Azért választottuk a backward modellt, mert összességében megbízhatóbb eredményt ad a forward modellnél (Sabzevari, Soleymani, \& Noorbakhsh, 2007). Az eredmény (11. függelék) azért nem a végleges 1. modell, mert fontosnak érezzük a szakirodalomban megfogalmazott hipotézisek tesztelését. A végső modellben tehát, számos 
iterációt követően az első lépésben a váltási korlátok (CONTRACT) és az elégedettség (NPS_CC), valamint a második lépésben az interakciós intenzitás (CC_CALLS) és elégedettség (NPS_CC) annak ellenére maradtak a modellben, hogy nem szignifikánsak, hiszen ezáltal vagyunk képesek hipotéziseinket tesztelni.

A $\lambda$ erős szignifikanciája azt fejezi ki, hogy fennáll a szelekciós torzítás az adatbázisban, vagyis a Heckman- féle korrekciós modell választása helyes volt. Mivel a Wald teszt is erősen szignifikáns, ez szintén alátámasztja a választott módszertan helyességét.

A pozitív $\rho$ érték azt jelenti, hogy a reziduumok korreláltak, vagyis az exogén és függő változók között kapcsolat van. Ebben az esetben ez azt jelenti, hogy a modell által nem megfigyelt, vagyis exogén változó pozitívan korrelál a lemorzsolódással (CHURN) és a használati intenzitás változásával (MINDIFF) egyaránt. Ilyen, nem megfigyelt változó lehet pl. a márka image, vagy a szolgáltatás- használatot befolyásoló pszichológiai tényezők. Ezekre vizsgálatunk nem terjed ki.

A csonkolási (truncation) hatás kiszámításával megállapíthatjuk, hogy a szelekciós eljárás pontosan mennyire torzítja a kivezetés előtti és utáni használati intenzitás változását (MINDIFF). Az átlagos mills ratio 0,3, amely azt jelenti, hogy a truncation hatás: $\lambda *$ átlagos mills érték $=0,778 * 0,3=0,2334$. A truncation hatás értelmezése a következö: egy átlagos tulajdonságokkal rendelkező, a szolgáltatáskivezetés során lemorzsolódott ügyfél $[\exp (0,2334)-1] * 100=26,29 \%$ - kal magasabb szolgáltatás-használattal rendelkezik, mint egy hasonló tulajdonságokkal rendelkező, véletlenszerüen kiválasztott ügyfél. Ez tehát azt is jelenti, hogy a lemorzsolódott ügyfelek magasabb szolgáltatás- használattal rendelkeznek azokhoz képest, akik a szolgáltatónál maradtak a szolgáltatáskivezetést követően, őket azonban nem vesszük figyelembe a modell második részében. Vagyis a folyamatban szelekciós torzítás áll fenn: a modell azt feltételezi, hogy a többet telefonálók nagyobb valószínűséggel hagyják el a szolgáltatót szolgáltatáskivezetés esetén, mint a kevesebbet telefonálók. Ezt a problémát kezeli a Heckman- féle korrekciós eljárás, amely a fó érvünk volt a módszertan választása mellett.

\subsection{4 ÉRZÉKENYSÉGI VIZSGÁLAT}

Az eredmények megbízhatóságának tesztelésére a kettős robosztusság szerint jártunk el (Carpenter, Kenward, \& Vansteelandt, 2006), amelynek vizsgálatához három modellre van szükség: az első modell tartalmazza a részben és teljes egészében megfigyelt adatot; a második modell csak teljes egészében megfigyelt adatot tartalmaz; és végül a harmadik modell az adatok megfigyelésének valószínüségét becsli. Cikkünkben adatbázis modellezést 
végzünk, nem megfigyelést, így a harmadik modell esetünkben irreleváns. Az általunk becsült 1. modellben az adatminőségi hibák miatt egy változót (logMFDIFF) imputálnunk kellett.

Ezek alapján az érzékenységi vizsgálat elvégzéséhez előállítunk egy olyan modellt, amelyben ez az imputált változó (logMFDIFF) nem szerepel, vagyis kizárólag teljes adatokat tartalmaz (10. táblázat). A 2. modellben, amely tehát nem tartalmazza a régi és új havidíj különbségének logaritmusát (logMFDIFF), a független változók koefficiensei nem térnek el jelentősen az 1. modellhez képest. Vagyis ez alapján kizárhatjuk a kihagyott változó okozta torzítás (omitted variable bias) lehetőségét, hiszen fontos kihagyott változó esetén jelentős eltérést tapasztalnánk a koefficiensekben a két modell között. Az érzékenységi vizsgálatot a másik prediktor (BEFORE_USAGE_MINUTES) esetében nem szükséges elvégezni, mivel az imputálás ezt a változót nem érintette.

Az McFadden $\mathrm{R}^{2}$ a 2. modell esetén a következő:

$$
\frac{(-2(-20529,41))-(-2(-17225,01)}{-2(-20529,41)}=\frac{41058,82-34450,02}{41058,82}=0,1609 .
$$

Az 1. modell 24,86\%-os potenciális javuláshoz képest elért értékkel szemben a 2. modell csak 16,09\%-os javulást ért el, vagyis ez alapján az 1. modell jobb, amely szintén igazolja a régi és új havidíj különbségének logaritmusának (logMFDIFF) használatát az elemzésben.

10. táblázat: A Heckman- féle korrekciós modell eredményei: 2 . modell ( $\mathrm{N}=8647$, a szignifikáns értékek vastag kiemeléssel szerepelnek)

\begin{tabular}{l|c|c|c}
\hline Függő változó & Együttható & $\begin{array}{c}\text { Standard } \\
\text { hiba }\end{array}$ & $P>z$ \\
\hline
\end{tabular}

2. lépés: A nem lemorzsolódott ügyfelek fogyasztói szokásainak elemzése szolgáltatáskivezetés esetén

\begin{tabular}{l|c|c|c} 
Függő változó: logMINDIFF & $-0,0149312$ & 0,0072252 & 0,039 \\
CC_CALLS & 0,1045050 & 0,0565815 & 0,065 \\
\hline D_CC_CALLS & $\mathbf{0 , 0 0 0 0 1 7 4}$ & $\mathbf{1 , 2 2 e - 0 6}$ & $\mathbf{0 , 0 0 0}$ \\
\hline BEFORE_USAGE_MINUTES & 0,0213189 & 0,0236883 & 0,368 \\
\hline NPS_CC & 0,3211523 & 0,1555119 & 0,039 \\
\hline D_NPS_CC & $\mathbf{- 1 , 3 5 8 7 8 2 0}$ & $\mathbf{0 , 1 6 1 3 2 9 7}$ & $\mathbf{0 , 0 0 0}$ \\
\hline Konstans & &
\end{tabular}

1. lépés: A lemorzsolódás becslése szolgáltatáskivezetés esetén 


\begin{tabular}{|c|c|c|c|}
\hline \multicolumn{4}{|l|}{ Függő változó: CHURN } \\
\hline TENURE & $\mathbf{0 , 0 0 0 3 2 7 7}$ & 0,0000415 & $\mathbf{0 , 0 0 0}$ \\
\hline CONTRACT & 0,0131845 & 0,0506456 & 0,795 \\
\hline CC_CALLS & 0,1167991 & 0,0230705 & 0,000 \\
\hline D_CC_CALLS & $-0,3164048$ & $\mathbf{0 , 0 7 0 5 4 2 5}$ & 0,000 \\
\hline BEFORE_USAGE_MINUTES & 5,55e-06 & 1,20e-06 & $\mathbf{0 , 0 0 0}$ \\
\hline NPS_CC & $-0,0380210$ & 0,0395436 & 0,336 \\
\hline D_NPS_CC & $-0,6001544$ & 0,3101814 & 0,053 \\
\hline Konstans & 1,3759690 & 0,3303945 & 0,000 \\
\hline ath $\rho$ & 0,4200895 & 0,0566100 & 0,000 \\
\hline $\ln \sigma$ & 0,5043151 & 0,0113615 & 0,000 \\
\hline$\rho$ & 0,3970058 & 0,0476875 & \\
\hline$\sigma$ & 1,6558510 & 0,0188130 & \\
\hline$\lambda$ & 0,6573826 & 0,0841658 & \\
\hline LR-teszt független egyenletekre & \multirow{2}{*}{\multicolumn{2}{|c|}{$\chi^{2}(1)=26,09$}} & \\
\hline$(\rho=0)$ & & & 0,0000 \\
\hline Megfigyelések száma (darab) & \multicolumn{3}{|c|}{8647} \\
\hline $\begin{array}{l}\text { Cenzorált megfigyelések száma } \\
\text { (darab) }\end{array}$ & \multicolumn{3}{|c|}{1585} \\
\hline $\begin{array}{l}\text { Nem cenzorált megfigyelések } \\
\text { száma (darab) }\end{array}$ & \multicolumn{3}{|c|}{7062} \\
\hline Wald $\chi^{2}(10)$ & \multicolumn{3}{|c|}{241,26} \\
\hline Log-likelihood & \multicolumn{3}{|c|}{$-17225,01$} \\
\hline Prob $>\chi^{2}$ & \multicolumn{3}{|c|}{0,0000} \\
\hline
\end{tabular}

\section{Forrás: saját szerkesztés}

Az eredmények megbízhatóságának tesztelésére a 2. modellen kívül mindkét modellre kiszámítjuk a robusztus standard hibákat (11. és 12. táblázat), ahol azt látjuk, hogy nem történt szignifikáns változás az első két modellhez képest. 
11. táblázat: A Heckman- féle korrekciós modell eredményei robusztus standard hibával: 1. modell ( $\mathrm{N}=\mathbf{7 7 6 6}$, a szignifikáns értékek vastag kiemeléssel szerepelnek)

Függő változó

Együttható \begin{tabular}{c|c} 
Standard & $P>z$ \\
hiba &
\end{tabular}

2. lépés: A nem lemorzsolódott ügyfelek fogyasztói szokásainak elemzése szolgáltatáskivezetés esetén

Függő változó: $\log$ MINDIFF

\begin{tabular}{l|c|c|c} 
logMFDIFF & $\mathbf{0 , 2 5 1 5 0 1 9}$ & $\mathbf{0 , 0 4 2 5 9 8 0}$ & $\mathbf{0 , 0 0 0}$ \\
\hline CC_CALLS & $-0,0145473$ & 0,0085981 & 0,091 \\
\hline D_CC_CALLS & 0,0825613 & 0,0653777 & 0,207 \\
\hline BEFORE_USAGE_MINUTES & $\mathbf{0 , 0 0 0 0 1 8 0}$ & $\mathbf{1 , 1 2 e - 0 6}$ & $\mathbf{0 , 0 0 0}$ \\
\hline NPS_CC & 0,0271769 & 0,0230514 & 0,238 \\
\hline D_NPS_CC & 0,3731505 & 0,1587034 & 0,019 \\
\hline Konstans & $\mathbf{- 1 , 4 3 3 9 5 8 0}$ & $\mathbf{0 , 1 6 6 5 2 9 6}$ & $\mathbf{0 , 0 0 0}$ \\
\hline
\end{tabular}

1. lépés: A lemorzsolódás becslése szolgáltatáskivezetés esetén

Függő változó: CHURN

\begin{tabular}{l|c|c|c} 
logMFDIFF & $\mathbf{- 0 , 1 0 6 3 1 3 6}$ & $\mathbf{0 , 0 3 0 7 1 5 2}$ & $\mathbf{0 , 0 0 1}$ \\
\hline TENURE & $\mathbf{0 , 0 0 0 3 1 4 7}$ & $\mathbf{0 , 0 0 0 0 5 5 2}$ & $\mathbf{0 , 0 0 0}$ \\
\hline CONTRACT & $-0,0282765$ & 0,0570230 & 0,620 \\
\hline CC_CALLS & $\mathbf{0 , 1 2 3 4 8 8 7}$ & $\mathbf{0 , 0 2 4 3 0 9 1}$ & $\mathbf{0 , 0 0 0}$ \\
\hline D_CC_CALLS & $\mathbf{- 0 , 3 3 9 0 4 6 4}$ & $\mathbf{0 , 0 7 6 7 5 2 6}$ & $\mathbf{0 , 0 0 0}$ \\
\hline BEFORE_USAGE_MINUTES & $\mathbf{6 , 0 0 e - 0 6}$ & $\mathbf{1 , 1 7 e - 0 6}$ & $\mathbf{0 , 0 0 0}$ \\
\hline NPS_CC & $-0,0332769$ & 0,0448099 & 0,458 \\
\hline D_NPS_CC & $-0,5202374$ & 0,3422641 & 0,129 \\
\hline Konstans & $\mathbf{1 , 3 2 6 7 6 1 0}$ & $\mathbf{0 , 3 4 3 0 1 5 6}$ & $\mathbf{0 , 0 0 0}$ \\
\hline ath $\rho$ & 0,5020116 & 0,0778257 & 0,000 \\
\hline $\ln \sigma$ & 0,5172867 & 0,0249509 & 0,000 \\
\hline$\rho$ & 0,4636977 & 0,0610920 & \\
\hline$\sigma$ & 1,6774700 & 0,0418544 & \\
\hline$\lambda$ & 0,7778390 & 0,1167677 & \\
\hline LR-teszt független egyenletekre & \multicolumn{2}{|c}{$\chi^{2}(1)=41,61$} & 0,0000 \\
\hline
\end{tabular}




\begin{tabular}{l|c}
\hline$(\rho=0)$ & 7766 \\
\hline Megfigyelések száma (darab) & 1502 \\
\hline Cenzorált megfigyelések száma & \\
(darab) & 6264 \\
\hline Nem cenzorált megfigyelések & 321,10 \\
száma (darab) & $-15425,09$ \\
\hline Wald $\chi^{2}(10)$ & 0,0000 \\
\hline Log-likelihood & \\
\hline Prob > $\chi^{2}$ & \\
\hline
\end{tabular}

\section{Forrás: saját szerkesztés}

12. táblázat: A Heckman- féle korrekciós modell eredményei robusztus standard hibával: 2. modell ( $\mathrm{N}=8647$, a szignifikáns értékek vastag kiemeléssel szerepelnek)

Függő változó

Együttható

\begin{tabular}{c|c} 
Standard & $P>z$ \\
hiba &
\end{tabular}

2. lépés: A nem lemorzsolódott ügyfelek fogyasztói szokásainak elemzése szolgáltatáskivezetés esetén

Függő változó: $\log$ MINDIFF

\begin{tabular}{l|c|c|c} 
CC_CALLS & $-0,0149312$ & 0,0082643 & 0,071 \\
\hline D_CC_CALLS & 0,1045050 & 0,0597535 & 0,080 \\
\hline BEFORE_USAGE_MINUTES & $\mathbf{0 , 0 0 0 0 1 7 4}$ & $\mathbf{1 , 0 4 e - 0 6}$ & $\mathbf{0 , 0 0 0}$ \\
\hline NPS_CC & 0,0213189 & 0,0213007 & 0,317 \\
\hline D_NPS_CC & 0,3211523 & 0,1470128 & 0,029 \\
\hline Konstans & $\mathbf{- 1 , 3 5 8 7 8 2 0}$ & $\mathbf{0 , 1 5 5 0 9 8 5}$ & $\mathbf{0 , 0 0 0}$ \\
\hline
\end{tabular}

1. lépés: A lemorzsolódás becslése szolgáltatáskivezetés esetén

Függő változó: CHURN

\begin{tabular}{l|c|c|c} 
TENURE & $\mathbf{0 , 0 0 0 3 2 7 7}$ & $\mathbf{0 , 0 0 0 0 4 6 3}$ & $\mathbf{0 , 0 0 0}$ \\
\hline CONTRACT & 0,0131845 & 0,0532785 & 0,805 \\
\hline CC_CALLS & $\mathbf{0 , 1 1 6 7 9 9 1}$ & $\mathbf{0 , 0 2 2 2 7 4 8}$ & $\mathbf{0 , 0 0 0}$ \\
\hline D_CC_CALLS & $\mathbf{- 0 , 3 1 6 4 0 4 8}$ & $\mathbf{0 , 0 7 1 7 9 7 7}$ & $\mathbf{0 , 0 0 0}$ \\
\hline BEFORE_USAGE_MINUTES & $\mathbf{5 , 5 5 e - 0 6}$ & $\mathbf{1 , 1 4 e - 0 6}$ & $\mathbf{0 , 0 0 0}$ \\
\hline NPS_CC & $-0,0380210$ & 0,0424532 & 0,370
\end{tabular}




\begin{tabular}{|c|c|c|c|}
\hline D_NPS_CC & $-0,6001544$ & 0,3288377 & 0,068 \\
\hline Konstans & 1,3759690 & 0,3291671 & 0,000 \\
\hline ath $\rho$ & 0,4200895 & 0,0728868 & 0,000 \\
\hline $\ln \sigma$ & 0,5043151 & 0,0224602 & 0,000 \\
\hline$\rho$ & 0,3970058 & 0,0613988 & \\
\hline$\sigma$ & 1,6558510 & 0,0371907 & \\
\hline$\lambda$ & 0,6573826 & 0,1114652 & \\
\hline LR-teszt független egyenletekre & \multirow{2}{*}{\multicolumn{2}{|c|}{$\chi^{2}(1)=33,22$}} & \\
\hline$(\rho=0)$ & & & 0,0000 \\
\hline Megfigyelések száma (darab) & \multicolumn{3}{|c|}{8647} \\
\hline Cenzorált megfigyelések száma & \multirow{2}{*}{\multicolumn{3}{|c|}{10585}} \\
\hline (darab) & & & \\
\hline Nem cenzorált megfigyelések & \multirow{2}{*}{\multicolumn{3}{|c|}{70062}} \\
\hline száma (darab) & & & \\
\hline Wald $\chi^{2}(10)$ & \multicolumn{3}{|c|}{325,82} \\
\hline Log-likelihood & \multicolumn{3}{|c|}{$-17225,01$} \\
\hline Prob $>\chi^{2}$ & \multicolumn{3}{|c|}{0,0000} \\
\hline
\end{tabular}

\section{Forrás: saját szerkesztés}

\subsection{5 ÖSSZEGZÉS}

A 3. tanulmányban arra a kérdésre kerestük a választ, hogy a szolgáltatáskivezetés esetén jelentkező magas lemorzsolódás hogyan csökkenthető, és milyen fogyasztói magatartásra gyakorolt hatásai vannak. Ahogyan a vállalati gyakorlat mutatja, a döntéshozók számára magas kockázatot jelent a szolgáltatáskivezetés, a folyamat során fellépő magas lemorzsolódás miatt.

Heckman- féle korrekciós eljárást használtunk annak eldöntésére, hogy különbséget tegyünk a változók lemorzsolódás elörejelző képessége között, és azt találtuk, hogy az árcsökkenés, a szerződés időtartama és az interakciós intenzitás szignifikánsan növelik az ügyfél-megtartást szolgáltatáskivezetés esetén. A váltási korlátok nem mutatnak szignifikáns hatást, amely valószínűleg a Dummy változó teljes váltási költségek mérési hiányosságára vezethetőek vissza. Ami a nem lemorzsolódott ügyfelek fogyasztói magatartását illeti, a kivezetést követő magasabb havidíj a várakozásainkkal összhangban növeli az ügyfél szolgáltatáshasználati intenzitását. 
A vállalati döntéshozók számára fontos eredmény, hogy a lemorzsolódás csökkenthető a kivezetés során az új ajánlat megfelelö árazásával, hiszen az alacsony váltási költségek miatt a korábbihoz képest magasabb havidíj a kedvezőbb versenytársi ajánlatok elfogadására ösztönözhetik az ügyfelet. Emellett az új, és a szolgáltatóval ritkábban kapcsolatba lépő, vagy a szolgáltató által ritkán felkeresett ügyfelek veszélyeztetett csoportnak tekinthetőek a szolgáltatáskivezetés szempontjából.

Kutatásunknak néhány korlátja van: először is, az áremelkedés változót a havidíjak különbsége helyett a teljes költésből számítva eltérő eredményt kaphatunk. Másodszor, a váltási korlátok hatása szignifikáns lehet, ha a váltáshoz köthető összes költség ismert az elemzés során. Harmadszor, a magyar telekommunikációs piac kivezetéskori állapotának tanulmányozása befolyásolhatta volna az eredményeket, az új havidíjak versenytársi ajánlatainak összevetésével. A további kutatási területek tehát olyan lehetséges empirikus vizsgálatokat vetnek fel, amelyek a szolgáltatáskivezetés és ügyfél-megtartás közti kapcsolatot modellezik a jelen tanulmány korlátainak figyelembe vételével.

A hipotéziseket tekintve tehát a következökre jutottunk:

8. Hipotézis: A szolgáltatáskivezetés esetén jelentkezö lemorzsolódás magasabb a normál lemorzsolódáshoz képest.- elfogadva

9. Hipotézis: Az áremelkedés csökkenti az ügyfélmegtartás valószinüségét szolgáltatáskivezetés esetén, árcsökkenéssel összehasonlítva.- elfogadva (9. táblázat)

10. Hipotézis: Az áremelkedés növeli a szolgáltatáskivezetést követő használat mértékét árcsökkenéssel összehasonlítva.- elfogadva (9. táblázat)

11. Hipotézis: A hosszabb szerzödéses kapcsolat a szolgáltatóval növeli az ügyfélmegtartás valószínüségét szolgáltatáskivezetés esetén, a rövidebb szerzödéses kapcsolattal összehasonlitva.- elfogadva (9. táblázat)

12. Hipotézis: A váltási korlátok növelik az ügyfélmegtartás valószinüségét szolgáltatáskivezetés esetén, a váltási korlátok hiányával összehasonlitva.- elutasitva (9. táblázat)

13. Hipotézis: Az interakciós intenzitás magasabb szintje növeli az ügyfélmegtartást szolgáltatáskivezetés esetén, az interakciós intenzitás alacsonyabb szintjével összehasonlitva.elfogadva (9. táblázat) 
14. Hipotézis: Az interakciós intenzitás magasabb szintje növeli a szolglátatáskivezetést követö alacsonyabb használat valószinüségét, az interakciós intenzitás alacsonyabb szintjével összehasonlítva.- elutasitva (9. táblázat) 


\section{5 ÖSSZEGZÉS}

„A képzelet sokkal fontosabb, mint a tudás. A tudás véges. A képzelet felöleli az egész világot."

(Albert Einstein)

A vállalatok jellemzően a szolgáltatások fejlesztésére összpontosítanak, és a szolgáltatáskivezetés stratégiai szintü kezelése háttérbe szorul. Ez befolyásolja az ügyfélmegtartást és vállalati bevételeket egyaránt, a szolgáltató vállalatoknál magas lemorzsolódást, növekvő költségeket, lekötött erőforrásokat és széttöredezett szolgáltatásportfóliókat eredményezve.

Jól tervezett és kivitelezett szolgáltatáskivezetés segítségével a szolgáltatásportfólió hatékonyabbá válhat, valamint az erőforrások más területekre allokálhatóak és ezáltal a szolgáltatáskivezetés költségei csökkenthetőek. Mindezek eredményeként a folyamat növeli a szolgáltatáskivezetést követő ügyfélmegtartás valószínüségét.

Napjainkban az ügyfélmegtartásnak kulcsfontosságú szerepe van, részben a szolgáltatási piacok stagnálása, részben pedig a vállalatok túlzott ügyfélszerzési (akvizíciós) fókusza miatt. A szolgáltatáskivezetés esetén szintén kulcsfontosságú az ügyfélmegtartás, hiszen a folyamat fontos hatásainak figyelmen kívül hagyása, mint például a magas lemorzsolódás, összességében a szolgáltatóvállalatok ügyfélbázisának csökkenését eredményezhetik. A kényszermigrációval átirányított ügyfelek jelentős része elhagyja a vállalatot szolgáltatáskivezetést követően az észlelt gazdasági és pszichológiai költségek miatt. Vagyis a gazdasági és pszichológiai költségek szerepe kritikus: a lemorzsolódás kockázatát elsősorban az új ajánlat hozzáadott értéke és a vállalat ügyféllel való interakciójának módja határozza meg.

Mindezek alapján a disszertációban a szolgáltatáskivezetés ügyfélreakcióit elemezzük. A szolgáltatáskivezetés területét szeretnénk új eredményekkel gazdagítani a szolgáltatáskivezetés kimenetének ügyfél szempontú elemzésével, amely betekintést nyújthat a szolgáltatáskivezetés területére, a gyakorlat számára is ajánlásokat megfogalmazva.

A szakirodalmi áttekintés rávilágított arra, hogy a témában kevés számú publikáció született, valószínüleg a szolgáltatáskivezetés sokrétüsége miatt. A legtöbb tanulmány termékekkel kapcsolatos, és a szolgáltatásokon belül elsősorban a pénzügyi szolgáltatások okait és folyamatát vizsgálják. A szakirodalmi áttekintés továbbá kiemelte, hogy a 
lemorzsolódás az ügyfélmegtartás mérőszáma, amelyet azonban nem használnak szolgáltatáskivezetés esetén.

Kutatásunk a kísérleti módszertan és adatbázis modellezés kombinációjával kívánja a folyamat során fellépő, jellemzően magas lemorzsolódás tényezőit feltárni. Mindhárom kutatásunk az ügyfél oldalt helyezi előtérbe: az 1. és 2. tanulmány kísérleti módszertanra, a 3. tanulmány adatbázis modellezésre épül. Az 1. tanulmányban a kísérleti módszertant használtuk a szolgáltatáskivezetés és az ügyfélreakcióhoz kötődő változók (lemorzsolódás, elégedettség, lojalitás, affektív és kalkulatív elkötelezettség és WOM) közti kapcsolat elemzésére a társadalmi csere elmélet alapján, a gazdasági és pszichológiai költséget használva független változókként. A kísérlet fő eredménye az, hogy amikor ezek a költségek interakcióba lépnek egymással, az ügyféllel való kapcsolatfelvétel módja erősebben befolyásolja az ügyfélmegtartást, mint az ajánlat minősége: kedvezőtlenebb ajánlat esetén a kivezetés előtti szóbeli értesítés hiánya alacsonyabb, míg kedvezőbb ajánlat esetén magasabb lemorzsolódáshoz vezet. Vagyis a pszichológiai költség gazdasági költséggel való interakciója váratlan hatást eredményez.

Habár az ügyféllel való közvetlen kommunikáció csökkentheti a pszichológiai költségeket, és ezáltal a kényszermigráció szükségességét, az ügyfelek mégis elhagyhatják a vállalatot, a szolgáltatóvállalat váratlan magyarázatának hatásai miatt. $\mathrm{Az}$ írott kommunikációnak limitált lehetősége van az új ajánlat megértésének támogatására, vagyis a kommunikáció közvetlenebbé válásával (például személyes vagy telefonos interakció által) az ügyfél felfigyel az új ajánlat hozzáadott értékére, akár jobb, akár rosszabb a jelenlegi szolgáltatásnál, amely befolyásolja a lemorzsolódást. Ez azt jelenti, hogy a szolgáltató vállalatoknak alaposan fel kell mérniük azokat a helyzeteket, ahol közvetlen kommunikáció szükséges a lemorzsolódás csökkentésére.

A 2. tanulmány szintén kísérleti módszertant használ, a társadalmi csere elmélet helyett az igazságosság elmélet alapján, a szolgáltatáskivezetés hatásának elemzésére. A szakirodalomban ezt az elméletet elsősorban szolgáltatási hiba ügyfelekre gyakorolt hatásának mérésére használják, szolgáltatáskivezetés esetében nem. Az eredmények szerint a disztributív és interakciós igazságosság pozitívan hatnak az ügyfélmegtartásra, elégedettségre és lojalitásra, míg a procedurális igazságosság nem szignifikáns. Az igazságosság dimenziónak interakcióját tekintve, a disztributív igazságosság bizonyult a legerősebbnek a lemorzsolódás csökkentését és elégedettség illetve lojalitás növelő hatását tekintve, mivel a 
procedurális és interakciós igazságosság inkább kompenzálják a disztributív igazságosságot, amennyiben az nincs jelen.

A 3. tanulmány egy magyar telekommunikációs szolgáltató adatbázisát vizsgálja, melynek célja a szolgáltatáskivezetés során tapasztalt, normál piaci körülményekhez képest magas lemorzsolódási indikátorainak a feltárása, a szolgáltatáscsomag és az ügyfél tulajdonságainak modellezésével, valós ügyfélreakciók alapján. A 3. tanulmány eredményei szerint az áremelkedés, a szerződés időtartama, az interakciós intenzitás és a kivezetés előtti használati intenzitás a szolgáltatáskivezetés esetén tapasztalt lemorzsolódás indikátorai, míg a váltási korlátok nem mutatnak szignifikáns hatást. Továbbá azok esetében, akik a kivezetést követően a vállalatnál maradtak, a használat tekintetében az figyelhető meg, hogy az áremelkedés és a kivezetés előtti használati intenzitás növelik az ügyfél szolgáltatáskivezetést követő használatának intenzitását. Ezt részben a fogyasztói tudatosság okozhatja, az ügyfelek valószínüleg sokkal inkább tudatában vannak a szolgáltatáscsomag feltételeinek a szolgáltatáskivezetés lezárulása után, hiszen az új feltételeket ezt megelőzően mérlegelniük kell. Ez egyúttal arra is magyarázatot adhat, hogy egy magasabb havidíj egy intenzív felhasználó esetében miért eredményez összességében intenzívebb használatot a szolgáltatáskivezetést követően, mint azelőtt, hiszen az ár-érték arány fontos számukra.

A 13. táblázatban foglaljuk össze a kutatási kérdéseket és a vizsgált hipotéziseket.

\section{3. táblázat: A kutatási módszertan összegzése}

\begin{tabular}{|c|c|c|c|c|}
\hline & Esettanulmány & 1. tanulmány & 2. tanulmány & 3. tanulmány \\
\hline $\begin{array}{l}\text { Kutatási } \\
\text { kérdések }\end{array}$ & - & $\begin{array}{l}\text { 1. Hogyan használható a } \\
\text { társadalmi csere elmélet a } \\
\text { szolgáltatáskivezetést } \\
\text { követő ügyfélreakció } \\
\text { (lemorzsolódás, } \\
\text { elégedettség, lojalitás, } \\
\text { affektív és kalkulatív } \\
\text { elkötelezettség, WOM) } \\
\text { magyarázatára? }\end{array}$ & $\begin{array}{l}\text { 2. Hogyan használható } \\
\text { az igazságosság elmélet a } \\
\text { szolgáltatáskivezetést } \\
\text { követő ügyfélreakció } \\
\text { (lemorzsolódás, } \\
\text { elégedettség, lojalitás, } \\
\text { affektív és kalkulatív } \\
\text { elkötelezettség, WOM) } \\
\text { magyarázatára? }\end{array}$ & $\begin{array}{l}\text { 3. Szolgáltatáskivezetés } \\
\text { esetén magasabb a } \\
\text { lemorzsolódás a normál } \\
\text { lemorzsolódáshoz képest? } \\
\text { 4. A szolgáltatáskivezetés } \\
\text { utáni lemorzsolódást } \\
\text { hogyan befolyásolják a } \\
\text { szolgáltatáskivezetés és az } \\
\text { ügyfél tulajdonságai? } \\
\text { 5. A } \\
\text { szolgáltatáskivezetést } \\
\text { követő használat } \\
\text { intenzitását hogyan } \\
\text { befolyásolják a } \\
\text { szolgáltatáskivezetés és az } \\
\text { ügyfél tulajdonságai? }\end{array}$ \\
\hline Hipotézisek & - & $\begin{array}{l}\text { H1: A gazdasági költség } \\
\text { növeli a lemorzsolódást, és } \\
\text { WOM-ot, és csökkenti az } \\
\text { elégedettséget, lojalitást, } \\
\text { affektív és kalkulatív } \\
\text { elkötelezettséget }\end{array}$ & $\begin{array}{l}\text { H4: A disztributív } \\
\text { igazságosság csökkenti a } \\
\text { lemorzsolódást, és növeli } \\
\text { az elégedettséget és } \\
\text { lojalitást } \\
\text { szolgáltatáskivezetés }\end{array}$ & $\begin{array}{l}\text { H8: A } \\
\text { szolgáltatáskivezetés } \\
\text { esetén jelentkező } \\
\text { lemorzsolódás magasabb a } \\
\text { normál lemorzsolódáshoz } \\
\text { képest. }\end{array}$ \\
\hline
\end{tabular}




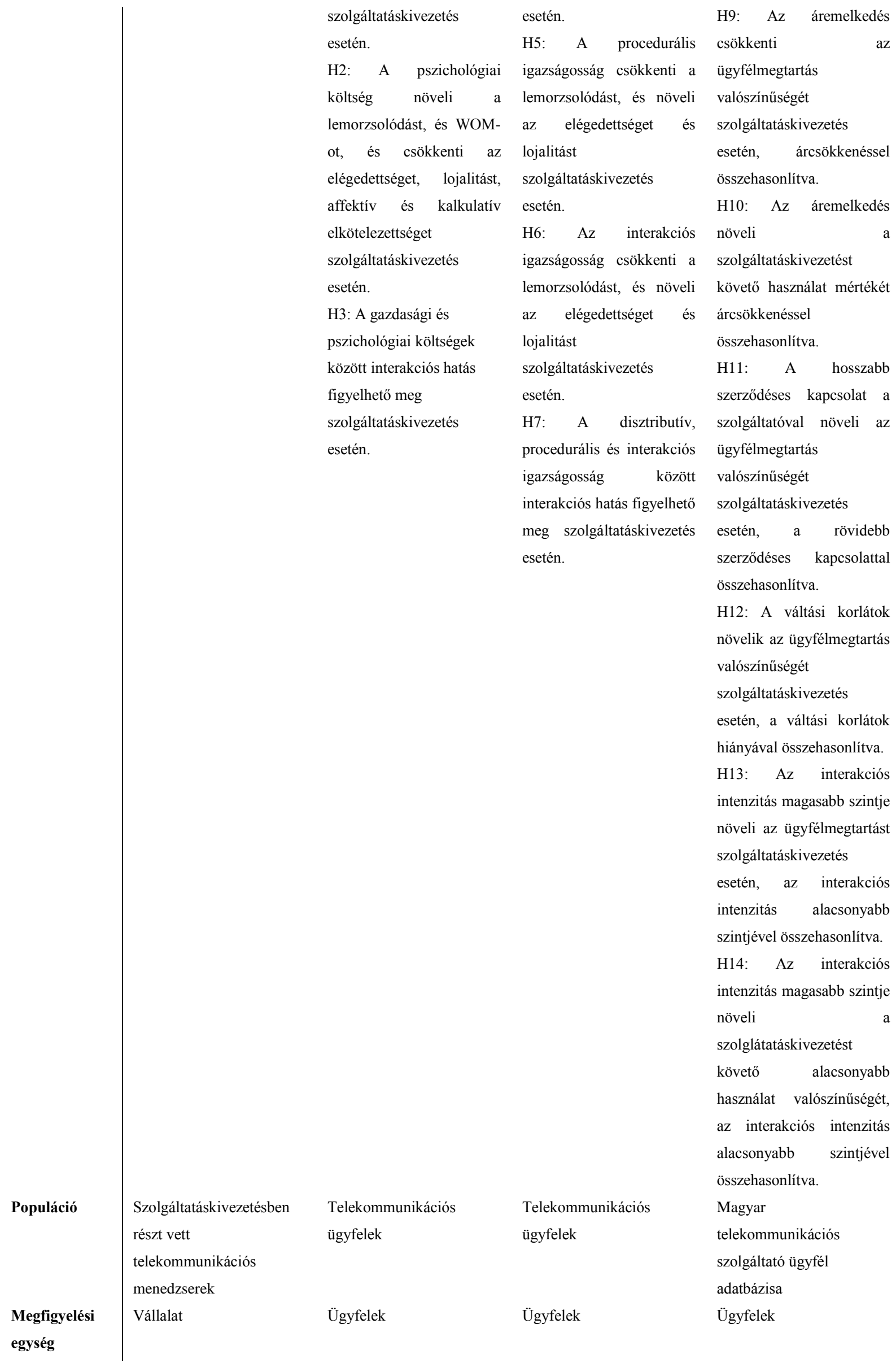




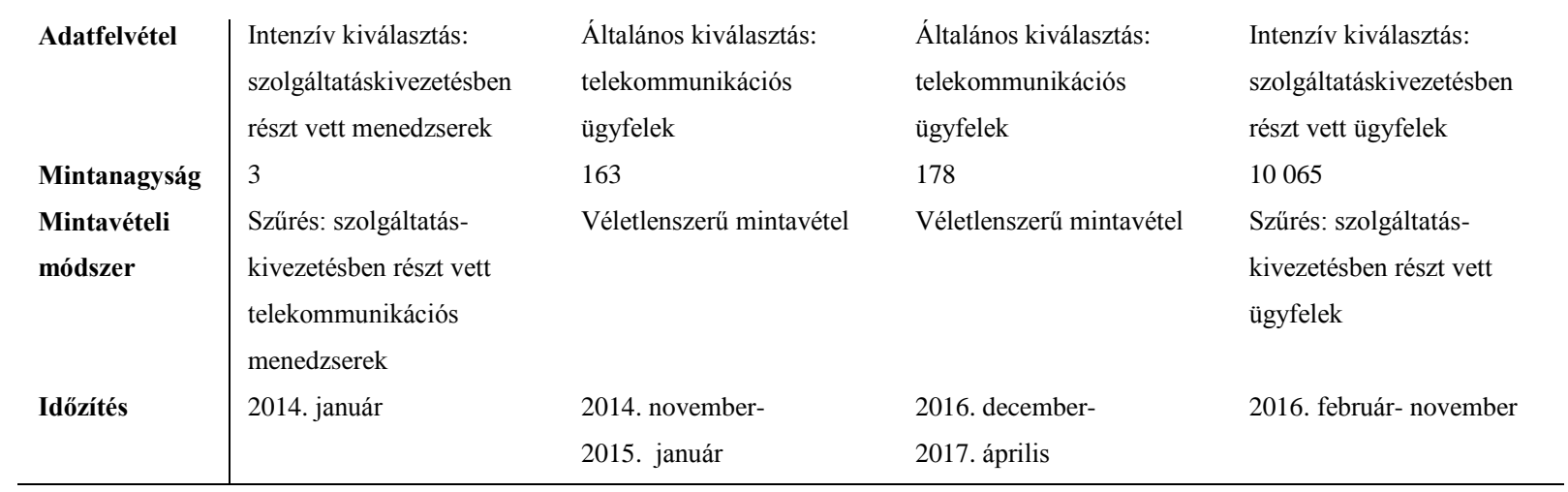

Forrás: saját szerkesztés

\subsection{A KUTATÁSI HIPOTÉZISEK ÉRTÉKELÉSE}

A tizennégy hipotézis közül kilencet korlátozás nélkül elfogadunk, kettőt részben tudunk elfogadni és hármat elutasítunk.

Az ajánlat minőségét három különböző formában mértük a három tanulmányban: gazdasági költséggel az 1. tanulmányban, disztributív igazságossággal a 2. tanulmányban és áremelkedéssel a 3. tanulmányban. Mindhárom azt méri, hogy a szolgáltatáskivezetés utáni szolgáltatás havidíja kedvezőbb volt-e, és azt találtuk, hogy a kedvezőbb ajánlat csökkenti a lemorzsolódást és WOM-ot, valamint növeli az elégedettséget, lojalitást, affektív és kalkulatív elkötelezettséget.

Ehhez hasonlóan, az interakció minősége szintén megjelent mindhárom tanulmányban: a pszichológiai költség az 1. tanulmányban, az interakciós igazságosság a 2. tanulmányban és az interakciós intenzitás a 3. tanulmányban. Eredményeink szerint a szolgáltató és ügyfél közötti interakció csökkenti a lemorzsolódást, és WOM-ot, valamint növeli az elégedettséget, lojalitást, affektív és kalkulatív elkötelezettséget. Felhasználói magatartásra vonatkozó hatását nem tudtuk igazolni; valószínűleg a kapcsolatuk sokkal inkább közvetett, amelyet kutatásunk által nem mért egyéb tényezők befolyásolhatnak.

A pszichológiai költségre vonatkozó hipotézist eredményeink az elégedettség, lojalitás, affektív elkötelezettség és szájreklám esetén támasztották alá, a lemorzsolódás esetében nem. Vagyis a szolgáltatáskivezetés miatt történő váltás váratlansága ugyan hatással van az ügyfél percepciójára, de a lemorzsolódást már nem befolyásolja.

Hasonlóképpen, az igazságosság elemei közötti interakciók (disztributív, procedurális és interakciós igazságosság) a lemorzsolódás és elégedettség esetében szignifikánsak a disztribúciós és procedurális igazságosság interakciójának esetében, és a procedurális és interakciós igazságosság interakciójában az elégedettségre vonatkozóan. Ez azt jelenti, egyrészt hogy egyrészt a procedurális igazságosság képes készben kompenzálni a 
disztribúciós igazságosság hiányát, másfelől az interakciós igazságosságnak a procedurális igazságosság esetében van részleges kompenzáló szerepe.

Az első elutasított hipotézis a procedurális igazságosságra vonatkozik, és részben ez is operacionalizálási kérdésekre vezethető vissza. Az ügyfelek ugyanis kevéssé érzékelnek különbséget egy szolgáltatótól érkező hívás, és az a helyzet között, amikor saját elbizonytalanodásuk eredményeképpen felhívják a szolgáltatót. Mégis meglepő, hogy a hosszú várakozási idő, és a többszöri próbálkozás a szolgáltatóval való kapcsolatfelvétel érdekében nincsenek szignifikáns hatással a lemorzsolódás, elégedettség és lojalitás értékeire.

A szakirodalom szerint a procedurális igazságosság időszerüséget, elérhetőséget és kényelmet fejez ki, amelyeket a forgatókönyvek létrehozásánál is használtunk. Mégis, a hatás nem szignifikáns az összes változó esetében, amely azt jelenti, hogy szolgáltatáskivezetés esetén a procedurális igazságosság definícióját pontosítani kellene: szolgáltatáskivezetés esetén valószínűleg a kényelmetlenséget, energia -és időráfordítást fejezi ki a teljes szolgáltatáskivezetési folyamat során, amely nem korlátozható a szolgáltatóval való telefonhívásra. Ez egy további kutatási terület lehetne.

Másodsorban, meglepő módon, a szolgáltatók által a lemorzsolódás csökkentésére alkalmazott gyakorlat a váltási korlátok használatára vonatkozóan nem nyert igazolást, amelyet valószínüleg az adatbázisban fellelhető mérési problémák okozhatnak. Az adatbázis kizárólag arra vonatkozóan tartalmaz információt, hogy az ügyfél két éves szerződése lejárt-e, vagyis hiányos atekintetben, hogy a szerződés felbontásának valódi összes költsége nem áll rendelkezésre. A hipotézis tesztelésére tehát a váltáshoz kötődő összes költség ismeretére szükség lenne, amely a kutatás következő lépése lehetne. A szolgáltatók egyetemekkel való együttmüködése lenne szükséges hasonló adatok iparági elemzéséhez.

Harmadsorban, az interakciós intenzitás szolgáltatáskivezetést követő használati intenzitásra gyakorolt hatását elutasítottuk, de mivel a szakirodalom empirikus eredményei sem egységesek ezzel kapcsolatban, ezért ez az eredmény a további kutatások szükségességét veti fel.

A hipotézisek eredményei a 14. táblázatban szerepelnek.

\section{4. táblázat: A kutatási hipotézisek összegzése}

\section{Hipotézis}

Eredmény

Referencia

H1: A gazdasági költség növeli a lemorzsolódást, és WOM-ot, és csökkenti az elégedettséget, lojalitást, affektív és kalkulatív Elfogadva 1. tanulmány elkötelezettséget szolgáltatáskivezetés esetén. 
H2: A pszichológiai költség növeli a lemorzsolódást, és WOM-ot, és csökkenti az elégedettséget, lojalitást, affektív és kalkulatív elkötelezettséget szolgáltatáskivezetés esetén. H3: A gazdasági és pszichológiai költségek között interakciós hatás figyelhető meg szolgáltatáskivezetés esetén.

H4: A disztributív igazságosság csökkenti a lemorzsolódást, és növeli az elégedettséget és lojalitást szolgáltatáskivezetés esetén.

H5: A procedurális igazságosság csökkenti a lemorzsolódást, és növeli az elégedettséget és lojalitást szolgáltatáskivezetés esetén.

H6: Az interakciós igazságosság csökkenti a lemorzsolódást, és növeli az elégedettséget és lojalitást szolgáltatáskivezetés esetén.

H7: A disztributív, procedurális és interakciós igazságosság között interakciós hatás figyelhető meg szolgáltatáskivezetés esetén.

H8: A szolgáltatáskivezetés esetén jelentkező lemorzsolódás magasabb a normál lemorzsolódáshoz képest.

H9: Az áremelkedés csökkenti az ügyfélmegtartás valószínűségét szolgáltatáskivezetés esetén, árcsökkenéssel összehasonlítva.

H10: Az áremelkedés növeli a szolgáltatáskivezetést követő használat mértékét árcsökkenéssel összehasonlítva.

H11: A hosszabb szerződéses kapcsolat a szolgáltatóval növeli az ügyfélmegtartás valószínüségét szolgáltatáskivezetés esetén, a rövidebb szerződéses kapcsolattal összehasonlítva.

H12: A váltási korlátok növelik az ügyfélmegtartás valószínüségét szolgáltatáskivezetés esetén, a váltási korlátok hiányával összehasonlítva.

H13: Az interakciós intenzitás magasabb szintje növeli az ügyfélmegtartást szolgáltatáskivezetés esetén, az interakciós intenzitás alacsonyabb szintjével összehasonlítva.
Részben elfogadva 1. tanulmány

Elfogadva 1. tanulmány

Elfogadva 2. tanulmány

Elutasítva 2. tanulmány

Elfogadva 2. tanulmány

Részben elfogadva $\quad$ 2. tanulmány

Elfogadva

3. tanulmány

Elfogadva

3. tanulmány

Elfogadva

3. tanulmány

Elfogadva 3. tanulmány

Elutasítva 3. tanulmány

Elfogadva 3. tanulmány 
H14: Az interakciós intenzitás magasabb szintje növeli a szolglátatáskivezetést követő alacsonyabb használat valószínüségét, az interakciós intenzitás alacsonyabb szintjével Elutasítva 3. tanulmány összehasonlítva.

\section{Forrás: saját szerkesztés}

\subsection{A KUTATÁS ELMÉLETI KONTRIBÚCIÓJA}

A kutatás jelentősége három fő részből áll. Először is, a szolgáltatáskivezetés utáni szakasz ügyfél szempontú elemzésével kutatásunk hozzájárul a szolgáltatáskivezetés szakirodalomhoz. A szolgáltatáskivezetés területén ugyanis a sikertényezőket egyrészt kizárólag a pénzügyi, és több szektort érintő tanulmányokban vizsgálták, másrészt pedig a teljesítmény eredményét kizárólag termelési szektorokban elemezték. Vagyis az ügyfél szempontú elemzés szolgáltatási területen a szolgáltatáskivezetési szakirodalomban jelentős rés (4. táblázat), az ügyfelet középpontba helyező tanulmányok kizárólag a termékkivezetést érintették (Avlonitis, 1983; Homburg et al., 2010). Az empirikus eredmények hiánya a területen tehát közismert (Harness, 2004), amely meghatározta kutatásunk fókuszát.

Másodsorban, a társadalmi csere elmélet és igazságosság elmélet segítségével sikerült betekintést nyernünk a folyamatba, amelynek összességében jobban kellene igazodnia az ügyfelek igényeihez és a közvetlen kommunikáció javíthatja a szolgáltatáskivezetés kimenetelét, amennyiben az ügyfél eziránt érdeklődést mutat, és nem váratlanul keresi fel a szolgáltató. A kutatás az igazságosság elmélet továbbfejlesztésének is tekinthető, hiszen annak alkalmazását kiterjeszti a szolgáltatási hibán túl a szolgáltatáskivezetési esetre. Szolgáltatáskivezetés esetén tudomásunk szerint még nem alkalmazták a társadalmi csere és igazságosság elméleteket az ügyfélreakciók magyarázatára.

Az 1. tanulmány a kísérleti módszertant alkalmazva tárja fel a szolgáltatáskivezetési folyamat során észlelt ügyfélreakciókat a társadalmi csere elmélet alapján. Az eredmények összességében a kedvező ajánlat (nincs gazdasági költség) lemorzsolódás és szájreklám csökkentő, valamint elégedettség, lojalitás és elkötelezettség (affektív és kalkulatív elkötelezettség) növelő hatására világítottak rá, és az értesítés váratlansága (pszichológiai költség) hasonló hatással van az ügyfélreakciókra. A gazdasági és pszichológiai költség interakciója azonban az értesítés felértékelődött szerepére hívta fel a figyelmet: az ajánlat minőségétől függően a pszichológiai költség szerepe eltérő. Az ajánlatok komplexitásával erösen összefügg ez a jelenség, hiszen az ügyfelek rendszerint nem értik a szolgáltatáskivezetésről szóló írásos, jogi tájékoztatást, emiatt a közvetlen interakció 
(telefonos értesítés) világít rá a hatályos jogszabályok szerint kötelező levélben kiküldött értesítés valódi tartalmára. Ezért eredményezheti ez a közvetlenebb interakció a kedvezőtlenebb ajánlat esetében a lemorzsolódás növekedését, míg kedvező ajánlat esetén éppen ellenkezőleg, az ügyfelek megtartásához járul hozzá.

A 2. tanulmány szintén kísérleti módszertanra épül, de az ügyfélreakciók megértését az igazságosság elméletre építi. Eredményeink szerint az igazságosság egyes elemei (disztribúciós, procedurális és interakciós igazságosság) hasonlóképpen befolyásolják az ügyfélreakciókat, mint a költségek, de az interakciók ebben az esetben a disztribúciós igazságosság procedurális igazságossággal, és az interakciós igazságosság procedurális igazságossággal való részleges kompenzációját emelték ki.

Harmadszor, a szakirodalom ilyen mélységben nem tárgyalja a szolgáltatáskivezetés ügyfelekre gyakorolt hatásait, azonban ez alapjaiban meghatározza a folyamat sikerességét. Szolgáltatáskivezetéstől függetlenül, általános helyzetekben a lemorzsolódás gyakran alkalmazott sikerességi mutatószám, amelyet erre a speciális helyzetre alkalmaztunk kutatásunkban. Vagyis, mivel a szolgáltatáskivezetés az általános lemorzsolódás modellezés egy különleges helyzetének tekinthető, hozzájárulhat a lemorzsolódás megértéséhez. A szolgáltatáskivezetés fő sikertényezője a szolgáltatáskivezetés utáni lemorzsolódás, amely az 1-2. tanulmány eredményei szerint erősen függ az új ajánlat minőségétől, valamint az interakció minőségétől és annak időzítésétől.

A 3. tanulmányban kiemelten a szolgáltatáskivezetési folyamat sikerességének fö előrejelző tényezőit határoztuk meg, amely az 1-2. tanulmányban feltárt ajánlat kedvezőségén és az interakció intenzitásán kívül rámutatott a szerződés időtartamának, és a használat mértékének jelentőségére is. Vagyis az új ügyfelek és/vagy a nem intenzív felhasználók a lemorzsolódás szempontjából veszélyeztetett csoportnak tekinthetőek a szolgáltatáskivezetési folyamat során.

Az általános lemorzsolódás szakirodalom szerint az árcsökkenés és a szerződés időtartama csökkenti a lemorzsolódás valószínűségét, amelyet eredményeink a szolgáltatáskivezetés esetében is alátámasztanak. Az interakciós intenzitás és a használat intenzitása szempontjából azonban nem egységes a lemorzsolódás szakirodalom, ilyen tekintetben az empirikus eredmények kibővítéséhez hozzájárulhatnak eredményeink.

A lemorzsolódás szakirodalom ezen változókkal kapcsolatos különböző nézeteinek egyik oka, hogy egyrészt az interakció intenzitása erősen függ a szolgáltatás életciklusától. A bevezetés és kivezetés szakaszai intenzívebb interakciót tehetnek szükségessé, az életciklus 
többi szakasza során az ügyfél azonban nem feltétlenül igényli ezt. A vélemények meglehetősen megoszlanak atekintetben, hogy mikor előnyös egy intenzívebb interakció. A 3. tanulmányban bemutatott eredményeink erősítik azt a nézetet, hogy a kivezetési szakasz intenzívebb interakciót tesz szükségessé a szolgáltató vállalat és az ügyfél között.

Másrészt, a használat intenzitása még ettől is megosztottabb területnek tekinthető a lemorzsolódás szakirodalomban. Eredményeink a használat intenzitásának lemorzsolódás csökkentő hatásához járulnak hozzá, emellett az áremelkedés használat intenzitásának fokozó jellegére is rámutattunk, amely a lemorzsolódás szakirodalomban szintén kevéssé vizsgált terület.

Negyedszer, a szolgáltatáskivezetés mind akadémiai, mind pedig gyakorlati szempontból kulcsfontosságúnak tekinthető a szolgáltatásportfólió- innováció és menedzsment területén. A szolgáltatáskínálat menedzsment része a szolgáltatás innováció és a szolgáltatáskivezetés egyaránt (Argouslidis, 2001), amely utóbbi a gyakorlatban kevéssé jelenik meg ilyen kontextusban. A meglévő szolgáltatások kivezetése által viszont felgyorsítható a szolgáltatások innovációja, amelynek a jelentőségét szeretnénk hangsúlyozni. Ezért fontos, hogy a kutatás a gyakorlati szakemberek számára is ajánlásokat fogalmaz meg, az ügyfélreakciókon keresztül megszerzett ismeretek szolgáltatáskivezetési stratégiába való implementálását tekintve. Kiemelt stratégiának tekinthető az ügyféllel való interakció minősége és annak időzítése.

\subsection{A KUTATÁS GYAKORLATI RELEVANCIÁJA}

\subsubsection{A SZOLGÁLTATÁSKIVEZETÉS ESETÉN JELENTKEZÖ LEMORZSOLÓDÁS A JELENLEGINÉL KEDVEZÖBB AJÁNLATTAL ÉS MEGFELELÖ MINŐSÉGÜ INTERAKCIÓVAL CSÖKKENTHETŐ}

Kutatásunkban a lemorzsolódás két fontos indikátorát azonosítottuk mindhárom tanulmányban: a kivezetést követő kedvezőtlenebb ajánlat és a hiányzó vagy rossz minőségü interakció (beleértve a közvetett kommunikációt vagy közvetlen kommunikációt az ügyfél iránti tisztelet és odafigyelés kifejezése nélkül) a szolgáltató és az ügyfél között.

A kedvezőtlenebb ajánlat magasabb lemorzsolódást eredményezett, amely a gyakorlatban is kihívást jelent a szolgáltatók számára, hiszen a szolgáltatás csomagok esetenként olyan speciális kedvezményeket biztosítanak az ügyfeleknek, amely a szolgáltató többi ajánlatában nem elérhetőek. Ezekben az esetekben a lemorzsolódás elkerülhetetlen, különösen abban az esetben, ha a szolgáltató versenytársai rendelkeznek hasonló feltételeket biztosító szolgáltatással. A kérdés tehát az, hogy a kedvezőtlenebb ajánlat percepcióját 
hogyan lehet módosítani (ha a szolgáltató portfóliójában nincsen a jelenlegihez hasonló kedvezményeket biztosító ajánlat). Az ajánlat minősége és a közvetlen kommunikáció (ügyfél változásokról történő értesítése, és az új ajánlatok magyarázata) interakciójából az derült ki, hogy míg kedvezőtlenebb ajánlat esetén a közvetlen kommunikáció csak az ajánlat kedvezőtlen elemeit hangsúlyozza, ezáltal növeli a lemorzsolódást, kedvezőbb ajánlat esetén az elönyök kiemelése csökkenti a lemorzsolódást.

Általánosságban elmondható, hogy az ügyfelek rendszerint nem értik a teljes folyamatot közvetlen magyarázat nélkül, a levélben való tájékoztatás, amely jogi kötelezettség is, nem elegendő. Másfelől, az interakció minősége szintén kulcsfontosságú: az ügyfélszolgálati munkatársaknak tisztelettel és türelemmel kell bánniuk az ügyféllel, olyan attitüdöt tanúsítva, amely biztosítja az ügyfél számára a jobb alternatíva megtalálását.

A 3. tanulmányban ezeken kívül további lemorzsolódás indikátorokat is azonosítottunk: az ügyfél szerződésének időtartama és a kivezetés előtti használati intenzitás. Mindkettő az ügyfél szolgáltató iránti elkötelezettségét fejezi ki, amelyet a hosszabb kapcsolat és az intenzívebb használat egyaránt növelnek. Vagyis a szolgáltatáskivezetés során veszélyeztetett csoportnak tekinthetőek az új ügyfelek, a szolgáltatáskivezetés elött kizárólag közvetett módon tájékoztatott ügyfelek, és a használat szempontjából nem intenzív felhasználók.

\subsubsection{A SZOLGÁLTATÓTÓL KAPOTT KEDVEZÖTLENEBB AJÁNLAT RÉSZBEN KOMPENZÁLHATÓ A} FOLYAMAT SORÁN ÉSZLELT INTERAKCIÓ MINÖSÉGÉVEL

Az 1. és 2. tanulmány a vizsgált változók közötti interakcióval kapcsolatban érdekes aspektusokat tártak fel.

$\mathrm{Az}$ 1. tanulmány rávilágított arra, hogy kedvezőtlenebb ajánlat esetén (a szolgáltatáskivezetés utáni szolgáltatás új havidíja magasabb az ügyfél jelenlegi havidíjánál) az ügyfél szolgáltatáskivezetés előtti telefonos értesítése növeli az ügyfél lemorzsolódásának valószínüségét. Ennek valószínüleg az az oka, hogy az ügyfelek a szolgáltatás pontos feltételeivel általában nincsenek tisztában, és ezért egy ilyen hívás tulajdonképpen figyelemfelkeltő szereppel bír, amely egy kedvezőbb ajánlat esetén előnyös (hiszen tudatosítja annak előnyös feltételeit), egy kedvezőtlenebb ajánlat esetén viszont éppen ellenkező hatást vált ki.

A 2. tanulmány a teljes szolgáltatáskivezetési folyamat során észlelt problémamentességet hangsúlyozza, mint például a folyamat időigénye, kényelmi szintje, észlelt igazságossága vagy a várakozási idő hossza, valamint a szolgáltató elérhetősége. Ezek a problémamentességet jelző tényezők részben képesek kompenzálni a kedvezőtlenebb ajánlat 
lemorzsolódásra és elégedettségre gyakorolt hatásait. Fontos hozzátenni, hogy a procedurális igazságosság definícióját szolgáltatáskivezetés esetében érdemes lenne a teljes folyamatra kiterjeszteni, annak hívásra való korlátozása helyett. Vagyis a szolgáltatóknak több hangsúlyt kellene fektetniük a teljes folyamat feltételeire, az ügyfél értesítésétől a szolgáltatás átváltásáig.

Másodsorban, a 2. tanulmány az észlelt kontroll szerepét is kiemelte, mivel magasabb elégedettségi szint érhető el a tisztelet és odafigyelés kifejezésével abban az esetben, ha az ügyfél kezdeményezte a hívást. Még, ha az ügyfél érdekelt is abban, hogy több információt szerezzen a szolgáltatáskivezetésről, a hívás nem megfelelő időzítése az észlelt kontroll elvesztéséhez vezethet, és ezek a negatív érzelmek már nem kompenzálhatóak egy jó minőségű interakcióval sem. Így egy összességében magasabb elégedettségi szint érhető el az ügyfél által indított hívással, egy nem megfelelően időzített, szolgáltató által indított hívással összehasonlítva. Például az időpontfoglalás megoldást nyújthat erre a kérdésre.

Összességében tehát egy problémáktól mentes szolgáltatáskivezetési folyamat jó minőségü interakcióval a szolgáltató vállalat és az ügyfél között, a hívás megfelelő időzítése és az ügyfél érdeklődése a szolgáltatáskivezetéssel kapcsolatban (vagyis az ügyfél dönt úgy, hogy felkeresi a szolgáltatót) csökkenthetik a kedvezőtlenebb ajánlathoz füződő negatív ügyfélpercepciókat.

\subsubsection{AZ ÁREMELKEDÉS NÖVELI AZ ÜGYFÉL HASZNÁLATÁNAK INTENZITÁSÁT} SZOLGÁLTATÁSKIVEZETÉST KÖVETÖEN

A 3. tanulmány a lemorzsolódás indikátorainak azonosítása mellett az ügyfél szolgáltatáskivezetést követő használat intenzitását is vizsgálta, amelyet két tényező befolyásol abban az esetben, ha az ügyfél a vállalatnál marad: az áremelkedés és az ügyfél szolgáltatáskivezetést megelőző szolgáltatás használati intenzitása növeli a szolgáltatáskivezetést követő használati intenzitást. Az áremelkedés azt jelenti, hogy az ügyfél magasabb havidíjú szolgáltatást vesz igénybe a szolgáltatáskivezetést követően, mint azelőtt, és a szolgáltatást a szolgáltatáskivezetés után intenzívebben használja.

A magyarázat részben az interakció minőségében rejlik: láthattuk, hogy kedvezőtlenebb ajánlat esetében az interakciónak figyelemfelkeltő hatása van az ügyfél számára. Azonban, ha az ügyfél keresi fel a szolgáltatót, a közvetlen kommunikáció minősége javíthatja az elégedettséggel és lojalitással kapcsolatos percepciókat. Vagyis azok, akik kedvezőtlenebb ajánlatot kapnak ugyan, de mégis a vállalatnál maradnak, valószínüleg számos alkalommal folytattak egyeztetést a szolgáltatóval a szolgáltatás új feltételeiről, és ezáltal sokkal inkább 
tudatában vannak a változással járó új feltételeknek. Valószínüleg az ügyfél nem a magasabb havidíj alapján dönt a szolgáltatóval való kapcsolat fenntartása mellett, hanem sokkal inkább ár-érték alapú ez a megfontolás. Az intenzív felhasználók inkább maradnak a szolgáltatónál, amely összességében azt jelenti, hogy elfogadják a magasabb árakat, amennyiben olyan szolgáltatásokhoz férnek ezáltal hozzá, amelyek számukra értékesek.

\subsection{AZ EREDMÉNYEK GYAKORLATI ALKALMAZHATÓSÁGA}

A szolgáltatáskivezetés lehetővé teszi új szolgáltatások bevezetését, és ezáltal a szolgáltatásportfólió átalakítását. A korábbi hasonló projektek rendszerint limitált számának köszönhetően, a menedzserek számára kihívást jelent az ilyen esetekben jelentkező magas ügyfél lemorzsolódás kezelése.

Az esettanulmány a téma gyakorlati relevanciáját hangsúlyozta: a telekommunikációs szolgáltatók a szolgáltatáskivezetést nem kezelik stratégiai szinten, amely a szolgáltatásfejlesztési folyamatokat akadályozza. Vagyis gyakorlati oldalról felmerült az igény olyan megoldásokra, amelyek képesek csökkenteni a lemorzsolódást szolgáltatáskivezetés esetén. Ehhez elsősorban az ügyfél igényeinek szolgáltatáskivezetési folyamathoz való igazítása szükséges, amellett, hogy a folyamatot sokkal inkább az ügyfélmegtartás részeként kellene csökkenteni, a lemorzsolódás csökkentése érdekében.

Gyakorlati szempontból úgy érezzük, hogy kutatásunk hozzájárulhat a vállalatok szolgáltatáskivezetéssel összefüggő gyakorlati kihívásainak kezeléséhez: mivel a szolgáltatáskivezetést a vállalatok többsége rendszerint nem stratégiai szinten kezeli, az ügyfél szempontú elemzés a szolgáltatáskivezetés folyamatát tekintve segíthet a teljes szolgáltatáskivezetési stratégia fejlesztésében, és a magas lemorzsolódási ráták csökkentésében.

A téma akadémiai relevanciáján túl, kutatásunk a szolgáltatáskivezetési gyakorlathoz is hozzájárul, a lemorzsolódáshoz vezető negatív ügyfélreakciók kezelésére kidolgozott módszereken keresztül. Ahogyan a kutatási módszertan során is kiemeltük, a szolgáltatáskivezetés egy meglehetősen összetett terület, amelynek tervezése és kivitelezése kulcsfontosságú a szolgáltatáskivezetés sikerességét tekintve. Az ügyfél számára felmerülő költségek, és az ajánlatok komplexitása meghatározzák az elégedettséget, lojalitást, elkötelezettséget és WOM-ot, amelyek befolyásolják az ügyfélmegtartást. Vagyis a kommunikáció módja és a kiválasztott ügyfélbázis szolgáltató által történő közvetlen értesítése meghatározza a szolgáltatáskivezetés sikerességét. 


\subsection{A KUTATÁS KORLÁTAI ÉS JÖVÖBENI LEHETSÉGES KUTATÁSI IRÁNYOK}

Kutatásunknak néhány korlátja van. Az esettanulmány egy telekommunikációs szolgáltatónál végzett három mélyinterjúból áll, amelyet ki lehetne egészíteni más szolgáltatóknál végzett elemzéssel, valamint a közép-kelet-európai régió más országainak kvalitatív elemzésével.

Másodsorban, a kísérleti módszertannak is számos korlátja van, hiszen tényleges szolgáltatáskivezetést követő magatartást nem képes mérni, kizárólag a szolgáltatáskivezetési helyzethez kötődő elképzelt reakciókat. Ennek ellenére a legtöbb hatás a szakirodalomban más esetek során (mint például a szolgáltatási hiba esetében) tapasztalt módon alakult szolgáltatáskivezetés esetében is, a procedurális igazságosság viselkedési tényezőkre (lemorzsolódás, elégedettség, lojalitás) való hatásán kívül. Ezért a további kutatásokban a független változók operacionalizálása terén is elöre lehet lépni. Először is, szükség van egy pszichológiai költség mérésére alkalmas valid skála fejlesztésére, mert az empirikus eredmények hiányában a pszichológiai költséget a szolgáltatáskivezetés váratlanságával és a folyamat során tapasztalt interakciókkal ragadtuk meg, amely azonban vélhetőleg nem teljesen képes az összes ilyen jellegü költség mérésére. Majd, ehhez hasonlóan, a procedurális igazságosságot is más területekhez képest eltérőnek látjuk szolgáltatáskivezetési helyzetben, és ezért a procedurális igazságosság általános leírását a teljes szolgáltatáskivezetési folyamathoz kellene igazítani, annak hívásértesítésre való korlátozása helyett.

Harmadsorban, az adatbázis modellezés annak ellenére, hogy az ügyfelek egy szolgáltatáskivezetés során tapasztalt valós viselkedésének elemzésére képes, számos adatminőségi problémával szembesültünk. A hiányzó adatok miatt, az áremelkedést kizárólag a havidíjak változásával tudtuk mérni, az ügyfél összes felmerülő költségében bekövetkezett változás azonban módosíthatja a szolgáltatáskivezetés hatását. Továbbá a váltási korlátok nem szignifikáns hatása nem felel meg a szakirodalom eredményeinek, illetve a gyakorlati tapasztalatnak. Úgy gondoljuk, hogy ez elsősorban a váltási költségekkel kapcsolatos korlátozottan elérhető információnak köszönhető, hiszen a szerződés lejáratának vizsgálata önmagában nem képes a váltási magatartást teljességében megragadni. Emellett a magyar telekommunikációs piac szolgáltatáskivezetéskor elérhető versenytársi ajánlatainak ismerete segíthetett volna a lemorzsolódás indikátorainak magyarázatában.

Habár a telekommunikációs szektort többek között szolgáltatáskivezetéssel kapcsolatos elemzés szempontjából ideális tulajdonságai miatt választottuk, a kutatás külső érvényessége növelhető lenne más szektorok bevonásával, hiszen a szolgáltatáskivezetést kizárólag telekommunikációban vizsgáltuk, és az adatok a közép-kelet-európai régión belül csak 
Magyarországról és Ausztriából származnak. A további kutatási irányok közül érdemes lenne az ICT szektort, nemzetközi viszonylatban vizsgálni, amely a következő lépés lehetne a szolgáltatáskivezetés és ügyfélreakcióinak átfogóbb jellegü elemzéséhez. 


\section{HIVATKOZÁSOK}

1. Abadie, A. (2005). Semiparametric difference-in-differences estimators. The Review of Economic Studies, 72(1), 1-19.

2. Abernathy, W. (1978). The Productivity Dilemma. Baltimore/London: John Hopkins University Press.

3. Abernathy, W., \& Utterback, J. (1979). Dynamics of Innovation in Industry. In C. Hill, \& J. Utterback, Technological Innovation for a Dynamic Economy. Oxford: Pergamon.

4. Achrol, R. S., \& Kotler, P. (1999). Marketing in the network economy. The Journal of Marketing, 146163.

5. Aksoy, L., Buoye, A., Aksoy, P., Larivière, B., \& Keiningham, T. (2013). A Cross-national Investigation of the Satisfaction and Loyalty Linkage for Mobile Telecommunications Services across Eight Countries. Journal of Interactive Marketing, 74-82.

6. Alexander, S., \& Ruderman, M. (1987). The Role of Procedural and Distributive Justice in Organizational Behavior. Social Justice Research, 1, 177-198.

7. Allen, N. J., \& Meyer, J. P. (1990). The measurement and antecedents of affective, continuance and normative commitment to the organization. Journal of Occupational and Organizational Psychology, $63(1), 1-18$

8. Allison, P. D. (1995). Survival Analysis Using the SAS System. A Practical Guide. Cary: NC: SAS Institute.

9. Analysis Mason. (2014). Central and Eastern Europe telecoms market: Concise trends and forecasts (6 countries) 2014-2019. Research forecast report.

10. Analysis Mason. (2014). Hungary Telecoms Market Report 2014. Analysys Mason Limited 2014.

11. Anderson, E. (1998). Customer Satisfaction and Word of Mouth. Journal of Service Research, 1, 5-17.

12. Andreassen, T. W. (2001). From disgust to delight Do customers hold a grudge? Journal of Service Research, 4(1), 39-49.

13. Arellano, M., \& Bover, O. (1995). Another look at the instrumental variable estimation of errorcomponents models. Journal of Econometrics, 68(1), 29-51.

14. Arend, R. (2006). SME — supplier alliance activity in manufacturing: contingent benefits and perceptions. Strategic Management Journal, 27, 741-763.

15. Argouslidis, P. (2007). The evaluation stage in the service elimination decision-making process: Evidence from the UK financial services sector. Journal of Services Marketing, 21(2), 122-136.

16. Argouslidis , P. (2007a). The evaluation stage in the service elimination decision-making process: Evidence from the UK financial services sector. Journal of Services Marketing, 21(2), 122-136.

17. Argouslidis, P. (2004). An empirical investigation into the alternative strategies to implement the elimination of financial services. Journal of World Business, 39(4), 393-413.

18. Argouslidis, P. (2006). Contextual effects on the objectives that financial institutions pursue through range pruning: evidence from the UK. Journal of Retailing and Consumer Services, 13(1), 15-33.

19. Argouslidis, P. C. (2001). The service elimination process: an empirical investigation into the British financial services sector, Doctoral dissertation, University of Stirling

20. Argouslidis, P. C., \& McLean, F. (2001). Service elimination decision making: preliminary empirical evidence from the UK financial services sector. International Journal of Bank Marketing, 19(4), 166-178. 
21. Argouslidis, P. C., \& McLean, F. (2001a). Service elimination decision making: preliminary empirical evidence from the UK financial services sector. International Journal of Bank Marketing, 19(4), 166-178.

22. Argouslidis, P., \& Baltas, G. (2007). Structure in product line management: The role of formalization in service elimination decisions. Journal of the Academy of Marketing Science, 35 (12), 475-491.

23. Argouslidis, P., \& McLean, E. (2004). Service elimination decision-making: The identification of financial services as candidates for elimination. European Journal of Marketing, 35(11-12), 1355-1381.

24. Argouslidis, P., \& McLean, F. (2001b). Financial service elimination: Objectives and problem situations. Journal of Financial Services Marketing, 5(3), 221-131.

25. Argouslidis, P., \& McLean, F. (2003). Service elimination decision-making: Analysis of candidates for elimination and remedial actions. Journal of Marketing Management, 19 (3-4),, 307-344.

26. Argouslidis, R. (2007b). Problem situations triggering line pruning in financial services: Evidence from the UK. International Journal of Bank Marketing, 25(6), 372-393.

27. Argouslidis, R. (2008). Determinants of the speed of elimination decision-making in financial services. Journal of Services Marketing, 22(3), 237-254.

28. Atuahene-Gima, K. (1996). Differential potency of factors affecting innovation performance in manufacturing and services firms in Australia. Journal of Product Innovation Management, 13(1), 35-52.

29. Avlonitis, G. (1983). Ethics and product elimination. Management Decision, 21(2), 37-45.

30. Avlonitis, G. (1983). The product elimination decision and strategies. Industrial Marketing Management, 72(1), 31-43.

31. Avlonitis, G. (1983-1984). Improving product elimination in engineering industries. Journal of General Management, 9(2), 42-56.

32. Avlonitis, G. (1984). Industrial product elimination: Major factors to consider. Industrial Marketing Management, 13(2), 11-85.

33. Avlonitis, G. (1985a). Product elimination decision-making: Does formality matter? Journal of Marketing, $49,41-52$

34. Avlonitis, G. (1985b). Advisors and decision makers in product eliminations. industrial Marketing Management, 14(1), 17-26.

35. Avlonitis, G. (1985c). The techno-economic ecology of the product elimination process. International Journal of Research in Marketing, 2(3), 175-184.

36. Avlonitis, G. (1986). The identification of weak industrial products. European Journal of Marketing, 20(10), 24-42.

37. Avlonitis, G. (1987). Linking different types of product elimination decisions to their performance outcome: Project dropstrat. International Journal of Research in Marketing 4(1), 43-57.

38. Avlonitis, G. (1993). Project dropstrat: What factors do managers consider in deciding whether to drop a project? European Journal of Marketing, 27(4), 35-57.

39. Avlonitis, G. (1985). Revitalizing weak industrial products. Industrial Marketing Management, 74(2), 93105.

40. Avlonitis, G. J. (1986). The management of the product elimination function: theoretical and empirical analysis. In A. Woodside, Business Marketing, 1. (pp. 1-66.). Greenwich: JAI Press. 
41. Avlonitis, G. J., \& James, B. G. (1982). Some Dangerous Axioms of Production Elimination Decisionmaking. European Journal of Marketing, 16(1), 36-48.

42. Avlonitis, G., \& Argouslidis, P. (2012). Tracking the evolution of theory on product elimination: Past, present, and future. The Marketing Review, 12(4), 345-379.

43. Avlonitis, G., \& Argouslidis, P. (2012). Tracking the evolution of theory on product elimination: Past, present, and future. The Marketing Review, 12 (4), 345-379.

44. Avlonitis, G., \& James, B. (1982). Some dangerous axioms of product elimination decision-making. European Journal of Marketing, 76(1), 36-48.

45. Avlonitis, G., Hart, S., \& Tzokas, N. (2000). An analysis of product deletion scenarios. Journal of Product Innovation Management, 17(1), 41 -56.

46. Aydin, S., \& Özer, G. (2005). The analysis of antecedents of customer loyalty in the Turkish mobile telecommunication market. European Journal of marketing, 39(7/8), 910-925.

47. Bakhshi, A., Kumar, K., \& Rani, E. (2009). Organizational justice perceptions as predictor of job satisfaction and organization commitment. International journal of Business and Management, 4(9), 145154.

48. Bálint, N. A. (2014). Szolgálatosodás Nyugat-Európában és Magyarországon. Hol tartunk és merre haladunk?: Egy nemzetközi felmérés nyomán. Vezetéstudomány. 2015. 46(5), 24-33. .

49. Bansal, H. S., \& Taylor, S. F. (1999). The service provider switching model (spsm) a model of consumer switching behavior in the services industry. Journal of Service Research, 2(2), 200-218.

50. Banville, G., \& Pletcher, B. (1974). The product elimination function. Journal of the Academy of Marketing Science, 2, 432-446.

51. Bányai, E. (1995). A szolgáltatás fogalmának marketingszempontú értelmezése. Marketing \& menedzsment, 1995. 29(2), 49-53.

52. Bányai, E. (1995). Minőség és fogyasztói elégedettség a szolgáltatásmarketingben. Marketing \& menedzsment, 1995. 29(3), 65-70.

53. Bateson, J. E. (1985). The self-service customer-empirical findings. In Emerging Perspectives on Services Marketing (pp. 50-3.). Chicago, IL.: American Marketing Association.

54. Bátor, A. (2007). A vevőelégedettség és a lojalitás kapcsolata a kereskedelmi bankok szférájában I. Marketing \& menedzsment, 41(2), 4-15.

55. Becser, N., \& Zoltayné Paprika, Z. (2004). Döntéstámogató modell a szolgáltatásminőség fejlesztéséhez SQI-DSS - egy új megközelítés. Vezetéstudomány, 35(6), 22-29.

56. Bendapudi, N., \& Berry, L. (1997). Customers’ Motivations for Maintaining Relationships with Service Providers. Journal of Retailing, 73 (1), 15-37.

57. Berács, J. (2006). Oktatási hub a láthatáron - Logisztikai tapasztalatok tanulságai. Vezetéstudomány, 37, 2-11.

58. Berry, L. L., \& Parasuraman, A. (1991). Marketing Services: Competing Through Quality. New York, NY: The Free Press.

59. Berson, A., Smith, S., \& Thearling, K. (2000). Building data mining applications for CRM. New York: McGraw-Hill. 
60. Berthon, P., \& John, J. (2014). From entities to interfaces. In R. F. Lusch, \& S. L. Vargo, The servicedominant logic of marketing: Dialog, debate, and directions (pp. 196-207). Routledge.

61. Bies, R., \& Moag, J. (1986). Interactional Communication Criteria of Fairness. In R. Lewicki, B. Sheppard, \& M. Bazerman, Research in Organizational Behavior (pp. 289-319). Greenwich, CT: JAI Press.

62. Bies, R., \& Shapiro, D. (1987). Interactional Fairness Judgements: The Influence of Causal Accounts. Social Justice Research, 1, 199-218.

63. Bitner, M. J. (1990). Evaluating Service Encounters: The Effects of Physical Surroundings and Employee Responses. Journal of Marketing, 54 (2), 69-82.

64. Bitner, M. J. (1992). Servicescapes: The impact of physical surroundings on customers and employees. Journal of Marketing, 57-71.

65. Bitner, M. J. (1992). Servicescapes: The Impact of Physical Surroundings on Customers and Employees. Journal of Marketing, 56, 57-71. .

66. Bitner, M. J. (2000). The Servicescape. In T. Swartz, \& D. e. Iacobucci, Handbook of Services Marketing and Management (pp. 37-50.). Thousand Oaks, CA: Sage.

67. Bitner, M., Booms, B., \& Tetreault, M. (1990). The Service Encounter: Diagnosing Favorable and Unfavorable Incidents. Journal of Marketing, 54, 71-85.

68. Blau, P. M. (1964). Exchange and power in social life. Transaction Publishers.

69. Blodgett, J. G., Hill, D. J., \& Tax, S. S. (1997). The effects of distributive, procedural, and interactional justice on postcomplaint behavior. Journal of Retailing, 73(2), 185-210.

70. Blodgett, J., \& Tax, S. (1993). The Effects of Distributive and Interactional Justice on Complainants' Repatronage Intentions and Negative Word-of-Mouth Intentions. Journal of Consumer Satisfaction, Dissatisfaction and Complaining Behavior, 6, 100-110.

71. Blomkvist, J., Holmlid, S., \& Segelström, F. (2010). Service design research: yesterday, today and tomorrow. In M. Stickdorn, \& J. Schneider, This is Service Design Thinking: Basics - Tools - Cases (pp. 308-315.). Amsterdam: BIS Publishers.

72. Bolton, R. N., \& Lemon, K. N. (1999). A dynamic model of customers' usage of services: Usage as an antecedent and consequence of satisfaction. Journal of Marketing Research, 171-186.

73. Bolton, R. N., \& Lemon, K. N. (1999). A dynamic model of customers' usage of services: Usage as an antecedent and consequence of satisfaction. Journal of marketing research, 171-186.

74. Bolton, R., Kannan, P., \& Bramlett, M. (2000). Implications of Loyalty Program Membership and Service Experiences for Customer Retention and Value. Journal of the Academy of Marketing Science, 95-108.

75. Boshoff, C., \& Allen, J. (2000). The influence of selected antecedents on frontline staff's perceptions of service recovery performance. International Journal of Service Industry Management, 11(1), 63-90.

76. Braun, M., \& Schweidel, D. (2011). Modeling Customer Lifetimes with Multiple Causes of Churn. Marketing Science 30(5), 881-902.

77. Brunner, M., \& Stadler, R. (1999). The impact of active networking technology on service management in a telecom environment. In Integrated Network Management, 1999. Distributed Management for the Networked Millennium. Proceedings of the Sixth IFIP/IEEE International Symposium (pp. 385-400.). 
78. Bucklin, R. E., \& Srinivasan, V. (1991). Determining interbrand substitutability through survey measurement of consumer preference structures. Journal of Marketing Research, 58-71.

79. Burnham, T. A., Frels, J. K., \& Mahajan, V. (2003). Consumer switching costs: a typology, antecedents, and consequences. Journal of the Academy of Marketing Science, 31(2), 109-126.

80. Calhoun, G. (1988). Digital cellular radio. . Norwood, MA: Artech House, Inc..

81. Cannon, J., \& Homburg, C. (2001). Buyer-supplier relationships and customer firm costs. Journal of Marketing, 65, 29-43.

82. Carman, J. M. (1980). Paradigms for marketing theory. Research in marketing, 3(1).

83. Carpenter, G. S., \& Lehmann, D. R. (1985). A model of marketing mix, brand switching, and competition. Journal of Marketing Research, 318-329.

84. Carpenter, J. R., Kenward, M. G., \& Vansteelandt, S. (2006). A comparison of multiple imputation and doubly robust estimation for analyses with missing data. Journal of the Royal Statistical Society: Series A (Statistics in Society), 169(3), 571-584.

85. Caruana, A. (2004). The impact of switching costs on customer loyalty: A study among corporate customers of mobile telephony. . Journal of Targeting, Measurement and Analysis for Marketing, 12(3), 256-268.

86. Cenfetelli, R., \& Schwarz, A. (2011). Identifying and Testing the Inhibitors of Technology Usage Intentions. Information Systems Research 22(4), 808-823.

87. Central Intelligence Agency. (2017, 06 12). The World Factbook. Retrieved from https://www.cia.gov/library/publications/the-world-factbook/geos/xx.html

88. Cermak, D. S., File, K. M., \& Prince, R. A. (1991). Complaining and praising in non-profit exchanges: When satisfaction matters less. Journal of Consumer Satisfaction, Dissatisfaction and Complaining Behavior, 4, 180-187.

89. Chebat, J. C., \& Slusarczyk, W. (2005). How emotions mediate the effects of perceived justice on loyalty in service recovery situations: an empirical study. Journal of Business Research, 58(5), 664-673.

90. Chikán, A., \& Demeter, K. (1994). Szolgáltatások -amit a termelés nyújt. Vezetéstudomány, 10., 5-11.

91. Chisholm, D., \& Norman, G. (2006). When to exit a product: Evidence from the US motion-picture exhibition market. American Economic Review, 96(2), 57-61.

92. Chuang, Y. F., \& Tsaih, Y. C. (2013). The correlations between price cuts/changes and fee sensitivity on the choice of mobile phone service provider. The Service Industries Journal, 33(12), 1178-1192.

93. Clemmer, E. (1993). An Investigation into the Relationships of Justice and Customer Satisfaction with Services. In R. Cropanzano, Justice in the Workplace: Approaching Fairness in Human Resources Management. Hillsdale, NJ: Erlbaum.

94. Clemmer, E. C., \& Schneider, B. (1996). Fair Service. In S. Brown, D. Bowen, \& T. (. Swartz, Advances in Services Marketing and Management, 5 (pp. 109-126.). Greenwich, CT: JAI Press.

95. ClintWorld GmbH. (2013, 07). ClintWorld Solutions. Retrieved 07 2013, from http://www.clintworldsolutions.com/cw/wp-content/uploads/2013/07/Clintworld_Whitepaper_ClintKPI.pdf

96. Colgate, M., \& Lang, B. (2001). Switching barriers in consumer markets: an investigation of the financial services industry. Journal of Consumer Marketing, 18(4), 332-347. 
97. Constantin, J. A., \& Lusch, R. F. (1994). Understanding resource management. Oxford, OH: The Planning Forum.

98. Cook, K. S., Cheshire, C., Rice, E. R., \& Nakagawa, S. (2003). Social exchange theory. In J. (. Delamater, Handbook of social psychology (pp. 61-88.). New York: Kluwer Academic/Plenum Publishers.

99. Craney, T. A., \& Surles, J. G. (2002). Model-dependent variance inflation factor cutoff values. Quality Engineering, 14(3), 391-403.

100. Crosby, L. A., \& Stephens, N. (1987). Effects of Relationship Marketing on Satisfaction, Retention, and Prices in the Life Insurance Industry. Journal of Marketing Research, 24, 404--11.

101. Crosby, L. A., Evans, K. R., \& Cowles, D. (1990). Relationship quality in services selling: an interpersonal influence perspective. The Journal of Marketing, 68-81.

102. Crowley, F. (2017). Product and service innovation and discontinuation in manufacturing and service firms in Europe. European Journal of Innovation Management, 20(2), 250-268.

103. Cusumano, M., Mylonadis, Y., \& Rosenbloom, R. (1992). Strategic Maneuvering and Mass-Market Dynamics: The Triumph of VHS over Beta. Business History Review, 66, 51-94.

104. Czepiel, J. A., \& Gilmore, R. (1987). Exploring the Concept of Loyalty in Services. In C. A. J. A. Czepiel, The Services Marketing Challenge: Integrating for Competitive Advantage (pp. 91-94.). Chicago, IL: AMA.

105. Dagger, T. S., Danaher, P. J., \& Gibbs, B. J. (2009). How often versus how long the interplay of contact frequency and relationship duration in customer-reported service relationship strength. . Journal of Service Research, 11(4), 371-388.

106. Damanpour, F. (1996). Organizational complexity and innovation: developing and testing multiple contingency models. Management Science, 42(5), 693-716.

107. Davidow, M. (2003). Have you heard the word? The effect of word of mouth on perceived justice, satisfaction and repurchase intentions following complaint handling. Journal of Consumer Satisfaction, Dissatisfaction and Complaining Behavior, 16, 67-80.

108. Davis, F. D. (1989). Perceived Usefulness, Perceived Ease of Use, and User Acceptance of Information Technology. MIS Quarterly, 13(3), 319-340.

109. Dawes, J. (2009). The effect of service price increases on customer retention the moderating role of customer tenure and relationship breadth. Journal of Service Research, 11(3), 232-245.

110. Day, G. S., \& Montgomery, D. B. (1999). Charting new directions for marketing. The Journal of Marketing, 3-13.

111. De Jong, J. P., \& Vermeulen, P. A. (2003). Organizing successful new service development: a literature review. Management Decision, 41(9), 844-858.

112. Demeter, K. (2009). Szolgáltatásmenedzsment Magyarországon a termelő és a szolgáltató vállalatoknál. Vezetéstudomány, 40(2), 9-22. .

113. Demeter, K. (2009). Szolgáltatások versenyképességének elemzése vállalati példák alapján. Vezetéstudomány, 0133-0179. 2009. 40(3), 29-37. .

114. Demeter, K. (2010). Szolgálatosodás, avagy az integrált termék-szolgáltatás rendszerek kialakulása és jellemzői. 124. sz. mühelytanulmány, BCE. 
115. Demeter, K., \& Gelei, A. (2002). Szolgáltatásnyújtás a tevékenységmenedzsment szemszögéből. Vezetéstudomány, 33(2), 2-14.

116. Demeter, K., \& Szász, L. (2012). Úton a megoldásalapú gondolkodás felé - szolgálatosodási jellemzők magyarországi termelővállalatoknál. Vezetéstudomány, 18(11), 34-45.

117. Demeter, K., \& Szász, L. (2012). Úton a megoldásalapú gondolkodás felé-szolgálatosodási jellemzők magyarországi termelővállalatoknál (Towards solution-based thinking: characteristics of servitization at Hungarian manufacturing companies). Vezetéstudomány/Budapest Management Review, 43(11), 34-45.

118. Dichter, E. (1966). How word-of-mouth advertising works. Harvard business review, 44(6), 147-160.

119. Dick, A. S., \& Basu, K. (1994). Customer loyalty: Toward an integrated conceptual framework. Journal of the Academy of Marketing Science, 22(2), 99-113.

120. Dinya, L. (1999). Marketing és közszolgáltatások. Marketing \& menedzsment, 33(5), 8-10.

121. Dobrai, K., \& Farkas, F. (2009). Tudásintenzív üzleti szolgáltatások. Vezetéstudomány, 40(7-8), 56-66.

122. Drótos, G. (1995). Vissza a jövőbe? : Outsourcing az információtechnológiai szolgáltatások körében. Vezetéstudomány, 26(12), 56-64.

123. Durugy, A., Kollár, P., \& Madarász, I. (2016). Eladói kompetenciák mérése próbávásárlással. Vezetéstudomány, 47(2)

124. Dwyer, F., Schurr, P., \& Sejo, O. (1987). Developing buyer- seller relationships. Journal of Marketing, 51(2), 11-27.

125. Edvardson, B., Gustafsson, A., \& Roos, I. (2005). Service Portraits in Service Research: A Critical Review. International Journal of Service Industry Management, 107-121.

126. Edvardsson, B., \& Olsson, J. (1996). Key concepts for new service development. Service Industries Journal, 16(2), 140-164.

127. Ehrenberg, A. S. (1988). Repeat Buying: Facts, Theory and Data. New York: Oxford University Press.

128. Ennew, C., \& Binks, M. (1996). Good and bad customers: the benefits of participating in banking relationship. International Journal of Bank Marketing, 14(2), 5-13.

129. Entrepreneur. (2017, 05 20). https://www.entrepreneur.com/. Retrieved from Entrepreneur Network: https://www.entrepreneur.com/article/225415

130. Ercsey, I. (2000). Garanciák hatása egy közüzemi szolgáltatás fogyasztói értékelésére. Marketing \& menedzsment, 40(4), 74-80.

131. Ercsey, I. (2004). Postai elégedettség a reklamációk tükrében. Marketing \& menedzsment, 38(6), 69-75.

132. Ercsey, I. (2014). Közös az értékteremtés a kulturális szektorban?[Is creation value co-creation value in the cultural sector?]. Marketing \& menedzsment, 48(3), 36-46.

133. Eurostat. (2017, 06 12). Eurostat- Statistics Explained. Retrieved from http://ec.europa.eu/eurostat/statisticsexplained/index.php/File:EU_gross_value_added_by_industry,_2001-2011.png\#filelinks

134. Evans, R. (1977). Add soft data to product elimination decisions. Industrial Marketing Management, 6(2), 91-94.

135. Farkas, E. (2003). Érték(?)teremtés - érték(?)esítés. Marketing \& menedzsment, 37(3), 12-18.

136. Fazekas, G., \& Tóth, G. (1998). Besorolt világ. Vezetéstudomány, 29(4), 30-40. 
137. Fehér, J., \& Bencsik, A. (2007). A frontvonali munkák minősége = emberierőforrás-menedzsment? Vezetéstudomány, 38(4), 55-61.

138. Fiáth, A., Megyes, J., \& Tóth, A. (2010). A hazai postapiaci liberalizációra való felkészülés kérdéskörei. Vezetéstudomány, 41(5).

139. Field, A. (2003). Discovering Statistics Using SPSS for Windows. New York: Sage Publications.

140. Fisk, R. P., Brown, S. W., \& Bitner, M. J. (1993). Tracking the evolution of the services marketing literature. Journal of retailing, 69(1), 61-103.

141. Fisk, R., \& Coney, K. (1982). Postchoice Evaluation: An Equity Theory Analysis of Consumer Satisfaction/Dissatisfaction with Service Choices. In K. Hunt, \& R. (. Day, Conceptual and Empirical Contributions to Consumer Satisfaction and Complaining Behavior (pp. 9-16.). Bloomington, IN: Indiana University Press.

142. Foa, E., \& Foa, U. (1980). Resource theory. Interpersonal behavior as exchange. In e. a. K. J. Gergen, Social exchange. advances in theory and research (pp. 77-94.). New York: Plenum.

143. Foa, U., \& Foa, E. (1974). Societal structures of the mind. Springfield, IL: Charles C. Thomas.

144. Fojtik, J., \& Farkas, L. (2001). Minőség és marketing : A pénzitézeti szolgáltatások példája. Vezetéstudomány, 32(10), 44-53.

145. Folger, R., \& Konovsky, M. (1989). Procedural Justice, Distributive Justice, and Reactions to Pay Raise Decisions. Academy of Management Journal, 32, 851-866.

146. Fornell, C. (1992). A National Customer Satisfaction Barometer:. Journal of Marketing, 6-21.

147. Fornell, C., \& Bookstein, F. L. (1982). Two structural equation models: LISREL and PLS applied to consumer exit-voice theory. Journal of Marketing Research, 440-452.

148. Fornell, C., \& Wernerfelt, B. (1987). Defensive Marketing Strategy by Customer Complaint Management- A Theoretical Analysis. Journal of Marketing Research, 337-346.

149. Fornell, C., Johnson, M., Anderson, E., Jaesung, C., \& Bryant, B. (1996). The American Customer Satisfaction Index: Nature, Purpose, and Findings. Journal of Marketing, 7-18.

150. Fournier, S. (2003). A consumer-brand relationship framework for strategic brand management. . UMI Dissertation Services.

151. Fournier, S., \& Yao, J. L. (1997). Reviving brand loyalty: A reconceptualization within the framework of consumer-brand relationships. International Journal of Research in Marketing, 14(5), 451-472.

152. Fullerton, G. (2003). When Does Commitment Lead to Loyalty? Journal of Service Research, 333-344.

153. Garbarino, E., \& Johnson, M. (1999). The Differential Roles of Satisfaction, Trust, and Commitment in Customer. Journal of Marketing, 70-87.

154. Garschhammer, M., Hauck, R., Hegering, H. G., Kempter, B., Radisic, I., Rolle, H., \& Nerb, M. (2001). Towards generic service management concepts a service model based approach. In Integrated Network Management Proceedings, 2001 IEEE/IFIP nternational Symposium (pp. 719-732.). IEEE.

155. Gelbrich, K., \& Roschk, H. (2011). A meta-analysis of organizational complaint handling and customer responses. Journal of Service Research, 14(1), 24-43.

156. Gelei, A., \& Gémesi, K. (2010). A Szolgáltatások Ellátási Láncának Speciális Menedzsment Jellemzői. Vezetéstudomány, 41(2), 45-58. 
157. George, W. R. (1990). Internal marketing and organizational behavior: A partnership in developing customer-conscious employees at every level. Journal of Business Research, 20(1), 63-70.

158. Gerpott, T. J., Rams, W., \& Schindler, A. (2001). Customer retention, loyalty, and satisfaction in the German mobile cellular telecommunications market. Telecommunications Policy, 25(4), 249-269.

159. Goldberger, A. (1983). Abnormal Selection Bias. In S. Karlin, T. Amemiya, \& L. Goodman, Studies in Econometrics, Time Series, and Multivariate Statistics (pp. 67-84.). New York: Academic Press.

160. Gopalakrishnan, S., \& Damanpour, F. (1997). A review of innovation research in economics, sociology and technology management. Omega, 25(1), 15-28.

161. Gounaris, S., Avlonitis, G., \& Papastathopoulou, P. (2006). Uncovering the keys to successful service elimination: Project servdrop. Journal of Services Marketing, 20(1), 24-36.

162. Goyette, I., Ricard, L., Bergeron, J., \& Marticotte, F. (2010). e-WOM Scale: word-of-mouth measurement scale for e-services context. Canadian Journal of Administrative Sciences/Revue Canadienne des Sciences de l'Administration, 27(1), 5-23.

163. Greenberg, J. (1990). Organizational Justice: Yesterday, Today, and Tomorrow. Journal of Management, 16, 399-432.

164. Greenley, G., \& Bayus, B. (1994). A comparative study of product launch and elimination decisions in UK and US companies. European Journal of Marketing 28\{2), 5-29.

165. Greenstein, S., \& Wade, J. (1998). The product life cycle in the commercial mainframe computer market, 1968-1982. RAND Journal of Economics, 29(4), 772-789.

166. Gremler, D. D., \& Brown, S. W. (1996). Service loyalty: its nature, importance, and implications. Advancing Service Quality: A global perspective, 171-180.

167. Gremyra, I., \& Witell, L. (2013). A Service Innovation Framework for Manufacturing Firms. Proceedings of the QUIS13 International Research Symposium on Service Excellence in Management, $36-44$.

168. Gronau, R. (1974). Wage comparisons: A selectivity bias. Journal of Political Economy 82, 1119-1143.

169. Grotte, J. (2010). Az információs és kommunikációs technológia hatása a turisztikai szolgáltatókra, különös tekintettel az utazásszervezőkre és -közvetítőkre. Marketing \& menedzsment, 44(3), 63-67. .

170. Grönroos, C. (1981). Internal Marketing-An Integral Part of Marketing Theory. In J. H. Donnelly, \& W. R. George, Marketing of Services (pp. 236-38.). Chicago, IL: : American Marketing Association, .

171. Grönroos, C. (1983). Strategic Management and Marketing in the Service Sector. Cambridge, MA: Marketing Science Institute.

172. Grönroos, C., \& Voima, P. (2013). Critical service logic: making sense of value creation and co-creation. Journal of the Academy of Marketing Science, 41(2), 133-150.

173. Gruber, H. (2001). Competition and innovation: The diffusion of mobile telecommunications in Central and Eastern Europe. Information Economics and policy, 13(1), 19-34.

174. Gruber, H., \& Verboven, F. (2001). The diffusion of mobile telecommunications services in the European Union. European Economic Review, 45(3), 577-588.

175. Guiltinan, J. P. (1989). A Classification of Switching Costs With Implications for Relationship Marketing. 1989 AMA Winter Educators'Conference: Marketing Theory and Practice. Eds. Terry L. Childers, Richard P. Bagozzi, and J. Paul Peter (pp. 216-220). Chicago: American Marketing Association. 
176. Gummesson, E. (1978). Toward a theory of professional service marketing. Industrial Marketing Management, 7(2), 89-95.

177. Gummesson, E. (1995). Relationship marketing: its role in the service economy. In W. J. Glynn, \& J. G. Barnes, Understanding Services Management (pp. 244-268.). New York: John Wiley \& Sons.

178. Gupta, S., Hanssens, D., Hardie, B., Kahn, W., Kumar, V., \& Lin, N. S. (2006). Modeling customer lifetime value. Journal of Service Research, 9(2), 139-155.

179. Gustafsson, A., \& Johnson, M. (2003). Competing in a Service Economy: How to Create a Competitive Advantage through Service Development and Innovation. San Francisco, CA: John Wiley \& Sons.

180. Gustafsson, A., Johnson, M., \& Roos, I. (2005). The Effects of Customer Satisfaction, Relationship Commitment Dimensions, and Triggers on Customer Retention. Journal of Marketing, 69(4), 210-218.

181. Gustafsson, A., Johnson, M., \& Roos, I. (2005). The Effects of Customer Satisfaction, Relationship Commitment Dimensions, and Triggers on Customer Retention. Journal of Marketing, 210-218.

182. Gyöngyösy, Z. (1998). A győztesek kiválóan szolgáltatnak. Marketing \& menedzsment, 32(5), 50-52.

183. Gyöngyösy, Z. (1999). A szolgáltatások fejlődésének új irányai. Marketing \& menedzsment, 33(5), 4-7.

184. Gyöngyösy, Z. (1999). Kreativitás, értékek és kommunikáció a termék- és szolgáltatástervezésben. Marketing \& menedzsment, 33(1), 14-16.

185. Ha, J., \& Jang, S. (2009). Perceived justice in service recovery and behavioral intentions: The role of relationship quality. International. Journal of Hospitality Management , 28 (3), 319-327.

186. Hámori, É. (1994). A hitelkártya mint fizetőeszköz. Vezetéstudomány, 4, 57-62. .

187. Hans-Reinhard, J., Herbert, H. M., \& Kuhár, P. (1996). A bankoknak is meg kell tanulniuk az eladás müvészetét. Marketing \& menedzsment, 30(6), 52-55.

188. Harness, D. R. (2004). Product elimination: a financial services model. International Journal of Bank Marketing, 22(3), 161-179.

189. Harness, D. R., \& Mackay, S. (1997). Product Deletion: A Financial Services Perspective. International Journal of Bank Marketing, 15 (1), 4-12.

190. Harness, D., \& Harness, T. (2012). Can product elimination support post-downsizing success aspirations? Journal of General Management, 38(2), 39-60.

191. Harness, D., \& Marr, N. (2001). Strategies for eliminating a financial services product. Journai of Product and Brand Management, 10\{7), 423-438.

192. Harness, D., \& Marr, N. (2004). A comparison of product elimination success factors in the UK banking, building society and insurance sectors. International Journal of Bank Marketing, 22(2), 126-143.

193. Harness, D., Marr, N., \& Goy, T. (1998). The identification of weak products revisited. Journal of Product and Brand Management, 7(4), 319-335.

194. Harness, T., \& Harness, D. R. (2007). The stages of fi nancial services product elimination. Journal of Financial Services Marketing 12, 197-207.

195. Harrison-Walker, L. J. (2001). The measurement of word-of-mouth communication and an investigation of service quality and customer commitment as potential antecedents. Journal of service research, 4(1), $60-75$.

196. Hart, C. W. (1988). The Power of Unconditional Service Guarantees. Harvard Business Review, 54-62. . 
197. Hart, C. W., Heskett, J. L., \& Sasser Jr, W. E. (1990). The profitable art of service recovery. Harvard business review, 68(4), 148-156.

198. Hart, S. (1988). The causes of product deletion in British manufacturing companies. Journai of Marketing Management, 3(3), 328-343.

199. Hart, S. (1989). Product deletion and the effects of strategy. European Journai of Marketing, 23(10), 6-17.

200. Heckman, J. (1979). Sample selection bias as a specification error. Econometrica 47, 153-161.

201. Heidrich, B. (2006). Ördögi körök vonzásában: A szolgáltatások menedzsmentjének sajátosságairól. Vezetéstudomány, 37(1), 50-59.

202. Heidrich, B., \& Somogyi, A. (2003). A szolgáltatás-vezetés értékalapú modellje a "köz-menedzsmentben". Marketing \& menedzsment, 37(5), 14-25.

203. Heidrich, B., \& Somogyi, A. (2005). Az elengedett kéz dilemmája, avagy A vezetők kulturális lehetőségei a szolgáltató és közigazgatási szervezetekben. Vezetéstudomány, 36(9), 2-14.

204. Hennig-Thurau, T., \& Klee, A. (1997). The Impact of Customer Satisfaction and Relationship Quality and Customer Retention: A Critical Reassessment and Model Development. Psychology \& Marketing, 14., 737-764.

205. Hetényi, I. (1992). A közösségi szektor kérdései Magyarországon. Vezetéstudomány, 6, 29-32.

206. Hetesi, E. (2002). A lojalitás mérési problémái a közüzemi szolgáltatóknál. In H. (szerk.)., 205-218.

207. Hetesi, E. (2003). A lojalitás definiálási és mérési problémái, a lojalitás hatása a jövedelmezőségre. Vezetéstudomány (34), 20-27.

208. Hetesi, E. (2003). A minőség, az elégedettség és a lojalitás mérésének problémái a szolgáltatásoknál, és azok hatása a jövedelmezőségre. Marketing \& Menedzsment, 5, , 42-50.

209. Hetesi, E. (2007). A lojalitás klaszterei a partneri és fogyasztói piacokon. Vezetéstudomány, 4-17.

210. Hetesi, E., \& Rekettye, G. (2001). A lakossági ügyfelek lojalításának mérése és elemzése egy magyar energiaszolgáltatónál. Vezetéstudomány, 32(9), 17-24.

211. Hetesi, E., \& Rekettye, G. (2005). A lojalitás dimenzióinak longitudinális mérése a hazai lakossági energiafogyasztók körében faktoranalíis alapján., Vezetéstudomány, 36, 48-57.

212. Hetesi, E., \& Révész, B. (2004). A kapcsolati marketing és a kommunikáció szerepe a közüzemi szolgáltatóknál a piaci liberalizáció folyamatában. Vezetéstudomány, 35(6), 30-37.

213. Hetesi, E., \& Veres, Z. (2005). Az elégedettség és a lojalitás empirikus vizsgálata a B2B piacon. MOKKA Konferenciakiadvány.

214. Hillier, J. (2000). Going round the back? Complex networks and informal action in local planning processes . Environment and Planning A, 32(1), 33-54.

215. Hise, R., \& McGinnis, M. (1975). Product elimination: Practices, policies and ethics. Business Horizons, $18(3), 25-32$.

216. Hise, R., Parasuraman, P., \& Viswanathan, R. (1984). Product elimination: The neglected management responsibility. Journai of Business Strategy, 4, 56-63.

217. Hitsch, G. (2006). An empirical model of optimal dynamic product launch and exit under demand uncertainty. Marketing Science, 25(1), 25-50.

218. Ho, T.-H., \& Zheng, Y.-S. (2003). Setting Customer Expectation in Service Delivery: An Integrated Marketing-Operations Perspective. Management Science. 
219. Hocutt, M. A., Bowers, M. R., \& Todd Donavan, D. (2006). The art of service recovery: fact or fiction? Journal of Services Marketing, 20(3), 199-207.

220. Hocutt, M. A., Chakraborty, G., \& Mowen, J. C. (1997). The impact of perceived justice on customer satisfaction and intention to complain in a service recovery. ACR North American Advances.

221. Hofmeister Tóth, Á., Simon, J., \& Sajtos, L. (2003). A fogyasztói elégedettség. Budapest: Alinea Kiadó.

222. Holland, S. E. (1984). An exploratory study of products used for enjoyment and enhancement purposes: Reasons for choice among brands . Journal of the Academy of Marketing Science, 12(2), 205-217.

223. Homans, G. C. (1958). Social behavior as exchange. American Journal of Sociology, 597-606.

224. Homburg, C., Fürst, A., \& Prigge, J.-K. (2010). A customer perspective on product eliminations: how the removal of products affects customers and business relationships. Academy of Marketing Science, 531549.

225. Hooker, N., Nayga, R. J., \& Siebert, J. (2002). The impact of HACCP on costs and product exit. Journal of Agricuitural and Applied Economics, 34, 165-174.

226. Hung, S. Y., Yen, D. C., \& Wang, H. Y. (2006). Applying data mining to telecom churn management. Expert Systems with Applications, 31(3), 515-524.

227. Huppertz, J., Arenson, S., \& Evans, R. (1978). An Application of Equity Theory to Buyer-Seller Exchange Situations. Journal of Marketing Research, 15, 250-260.

228. Incze, E. (2013). A hazai védekezőtől a regionális „támadóig”-az OTP nemzetköziesedésének időbeni alakulása (From the domestic defender to the regional striker-a timebased process of the OTP Bank's internationalization). Vezetéstudomány/Budapest Management Review, 44(3), 2-15.

229. International Telecommunications Union. (1995). World Telecommunication Development Report 1995. Geneva: Information Infrastructures.

230. Jackson, B. (1985). Winning and Keeping Industrial Customers. Lexington: Lexington Books.

231. Jasso, G. (2006). Emotion in justice processes. Handbook of the Sociology of Emotions, 321-346.

232. Jeanne Hill, C. (1988). Differences in the consumer decision process for professional vs. generic services. Journal of Services Marketing, 2(1), 17-23.

233. Jenei, G. (1997). Közpolitikai döntések és a modern bürokrácia szerepének változása. Vezetéstudomány, 28(7-8), 3-12.

234. Jenei, G. (2000). Stratégiai szemlélet és új közintézményi menedzsment. Vezetéstudomány, 31(9), 2-11.

235. Jenei, G., \& Kemenes, E. (1992). Elgondolások a gyakorlati szakemberek továbbképzésére. Vezetéstudomány, 6, 13-20.

236. Jenei, G., \& Kuti, É. (2011). Versenyképesség és civil szerepvállalás a közigazgatás és a közszolgáltatások fejlesztésében (Competitiveness and civil contribution to the development of public administration and public services). Vezetéstudomány/Budapest Management Review, 42(1), 15-23.

237. Jobbágy, V. (2010). A mérés-értékelés szerepe: a szakpolitika-alapú kormányozásban, közigazgatásban és a közszolgáltatások nyújtásában. Vezetéstudomány, 41(3).

238. Johne, A., \& Storey, C. (1998). New service development: a review of the literature and annotated bibliography. European journal of Marketing, 32(3/4), 184-251.

239. Johnson, M., \& Fornell, C. (1991). A Framework for Comparing Customer Satisfaction Across Individuals and Product Categories. Journal of Economic Psychology, 267-286. 
240. Jones, M. A., Mothersbaugh, D. L., \& Beatty, S. E. (2002). Why customers stay: measuring the underlying dimensions of services switching costs and managing their differential strategic outcomes. Journal of Business Research, 55(6), 441-450.

241. Jones, T. O., \& Sasser, W. E. (1995). Why satisfied customers defect. Harvard Business Review, 73., 8899.

242. Judd, R. C. (1964). The Case for Redefining Services. Journal of Marketing, 28, 58-59.

243. Kádárné Horváth, Á. (2012). A távfütés szerepe az energiapolitikai célok elérésében. Vezetéstudomány, 43

244. Kamakura, W., Mela, C., Asnari, A., Bodapati, A., Fader, P., Iyengar, R., Wilcox, R. (2005). Choice Models and Customer Relationship Management. Marketing Letters 16:3/4., 279-291.

245. Kasper, H. (1988). On problem perception, dissatisfaction and brand loyalty. Journal of Economic Psychology, 9(3), 387-397.

246. Kasper, J. D., van Helsdingen, P. J., Gabbott, M., \& Fuxiang, W. (2008). Services marketing management. A strategic perspective. Chichester: Wiley.

247. Kastalli, I. V., \& Van Looy, B. (2013). Servitization: Disentangling the impact of service business model innovation on manufacturing firm performance. Journal of Operations Management, 31(4), 169-180.

248. Katz, K., Larson, B., \& Larson, R. (1991). Prescription for the Waiting in Line Blues: Entertain, Enlighten, and Engage. Sloan Management Review, 44-53.

249. Keaveney, S. M. (1995). Customer switching behavior in service industries: An exploratory study. . The Journal of Marketing, 71-82.

250. Keiningham, T. L., Cooil, B., Aksoy, L., Andreassen, T. W., \& Weiner, J. (2007). The value of different customer satisfaction and loyalty metrics in predicting customer retention, recommendation, and share-ofwallet. Managing Service Quality: An International Journal, 17(4), 361-384.

251. Kelley, S. W., Donnelly, J. H., \& Skinner, S. J. (1990). Customer participation in service production and delivery . Journal of Retailing, 66(3), 315-335.

252. Kemenes, E., \& Váradi, L. (1992). A BKE oktatásfejlesztési programja a közpolitikával és a közszolgáltatási szektorral kapcsolatos kérdések feldolgozására. Vezetéstudomány, 6, 5-12.

253. Kempf, D. (1999). Attitude Formation from Product Trial: Distinct Roles of Cognition and Affect for Hedonic and Functional Products. Psychology \& Marketing, 35-50.

254. Kenesei, Z. (1996). A bankmarketing fejlödésének várható tendenciái az elkövetkezendő évtizedben. Vezetéstudomány, 27(2), 29-35.

255. Kenesei, Z., \& Kolos, K. (2008). A hatékony panaszkezelés lehetőségei: kompenzáció és bocsánatkérés (Efficient possibilities of the customer complaints: compensation and apology). Vezetéstudomány/Budapest Management Review, 39(5), 27-39.

256. Kenesei, Z., \& Kolos, K. (2016). Az érzelmek és az észlelt kontroll szerepe a vállalati panaszkezelés során. Vezetéstudomány/Budapest Management Review, 47(9), 15-25.

257. Kenesei, Z., \& Kolos, K. (2016). Szolgáltatásmarketing: Múlt vagy jövő. MTA Vitaülés, 2016. 12. 19.

258. Kenesei, Z., \& Szántó, S. (1998). A szolgáltatásminősítés mérése - elmélet és gyakorlat. Vezetéstudomány, 29(12), 8-18. 
259. Kenesei, Z., \& Szilvai, Z. (2016). Mennyibe kerül egy szolgáltatási hiba? A fogyasztók által elvárt kompenzáció nagyságának vizsgálata. Marketing \& Menedzsment 50(2), 19-30.

260. Kent, R., \& Argouslidis, P. (2005). Shaping Business Decisions Using Fuzzy-Set Analysis: Service Elimination Decisions. Joumal of Marketing Management, 641-658.

261. Kim, H. (2000). The churn analysis and determinants of customer loyalty in Korean mobile phone. Korean Information Society Review, 2000, 1-18.

262. Kim, M. K., Park, M. C., \& Jeong, D. H. (2004). The effects of customer satisfaction and switching barrier on customer loyalty in Korean mobile telecommunication services. Telecommunications Policy, 28(2), 145-159.

263. Kim, M., Kliger, D., \& Vale, B. (2003). Estimating switching costs: the case of banking. Journal of Financial Intermediation, 12., 25-56.

264. Kimberly, J. (1981). Managerial innovation. In P. Nystrom, \& W. (. Starbuck, Handbook of Organization Design. Oxford: Oxford University Press.

265. Kincsesné Vajda, B. (2014). Az egészségügyi ellátás minőségének SERVQUAL szempontú mérése. Marketing \& menedzsment, 48(1), 47-58.

266. Kingman-Brundage, J. (1989). Technology, Design and Service Quality. International Journal of Service Industry Management, 2 (3), 47-59. .

267. Klemperer, P. (1987). Markets with consumer switching costs. The Quarterly Journal of Economics, 102., 376-394.

268. Klemperer, P. (1995). Competition when consumers have switching costs: an overview with applications to industrial organization, macroeconomics and international trade. Review of Economic Studies, 62., 51539.

269. Knox, G., \& Oest, R. (2014). Customer Complaints and Recovery Effectiveness: A Customer Base Approach. Journal of Marketing, 78., 42-57.

270. Kolos, K., \& Berács, J. (1999). Kedvezőtlen tapasztalatok elemzése a szolgáltatásoknál : Benzinkutak és autószervizek példája. Marketing \& menedzsment, 33(5), 59-63.

271. Kolos, K., \& Városiné Demeter, K. (1995). Szolgáltatások : A fogyasztók elvárásai és választási szempontjai. Vezetéstudomány, 36(6), 12-19.

272. Koltai, T., Romhányi, G., \& Tatay, V. (2009). Optimalizálás bizonytalan paraméterekkel a termelés- és szolgáltatásmenedzsmentben. Vezetéstudomány, 40, 68-73.

273. Koósa, A. (2001). Kritikus esetek vizsgálata a légi utasszállításban. Marketing \& menedzsment, 35(1), 4451.

274. Kotler, P. (1994). Marketing management. Analysis, planning, implementation, and control (8th ed.). Englewood Cliffs: NJ: Prentice-Hall.

275. Kovács, E. (2000). A fogyasztói elégedettséget megalapozó szolgáltatásminőség. Marketing \& menedzsment, 34(5), 55-56.

276. Kovács, P. (2008). A multikollinearitás vizsgálata lineáris regressziós modellekben. Statisztikai Szemle, 86(1), 38-67.

277. Kővágó, G. (2014). Tudásintenzív üzleti szolgáltatások marketinginnovációs eszközeinek vizsgálata a mikro-és kisvállalkozási szektorban. Marketing \& menedzsment, 48(3), 71-84. 
278. Krueger, A. B., \& Card, D. (1994). Minimum Wages and Employment: A Case Study of the Fast-Food Industry in New Jersey and Pennsylvania. American Economic Review. 84 (4), 772-793.

279. Kumar, V., \& Petersen, J. A. (2012). Statistical Methods in Customer Relationship Management. John Wiley \& Sons, Ltd.

280. Kurtz, D. L., \& Clow, K. E. (1998). Services marketing. New York: John Wiley \& Sons.

281. LaBarbera, P., \& Mazursky, D. (1983). A Longitudinal Assessment of Consumer Satisfaction/Dissatisfaction: The Dynamic Aspect of the Cognitive Process. Journal of Marketing Research, 393-404.

282. Lam, S. Y., Shankar, V., Erramilli, M. K., \& Murthy, B. (2004). Customer value, satisfaction, loyalty, and switching costs: an illustration from a business-to-business service context. Journal of the Academy of Marketing Science, 32(3), 293-311.

283. Lambe, C., \& Spekman, R. (1997). Alliances, External Technology Acquisition, and Discontinuous Technological Change. Journal of Product Innovation Management, 14, 102-116.

284. Larsson, R., \& Bowen, D. E. (1989). Organization and customer: managing design and coordination of services. Academy of Management Review, 14(2), 213-233.

285. Lee, J., Lee, J., \& Feick, L. (2001). The impact of switching costs on the customer satisfaction-loyalty link: mobile phone service in France. Journal of Services Marketing, 15(1), 35-48.

286. Lee, M., \& Cunningham, L. F. (2001). A cost/benefit approach to understanding service loyalty. Journal of Services Marketing, 15(2), 113-130.

287. Lehtinen, U., \& Lehtinen, J. R. (1982). Service quality: a study of quality dimensions. Unpublished Working Paper, Helsinki: Service Management Institute.

288. Letenyei, K., \& Papp, J. (2005). A kávé, mint termék, a kávézás mint szolgáltatás jellemző jegyei, versenyterei. Marketing \& Menedzsment, 1219-0349. 2005. 39. évf. 2. szám, 49-58.

289. Lewis, H. G. (1974). Comments on selectivity biases in wage comparisons. Journal of Political Economy 82., 1145-1155.

290. Lewis, M. (2005). Research note: A dynamic programming approach to customer relationship pricing. Management Science, 51(6), 986-994.

291. Lewis, M. (2006). Customer acquisition promotions and customer asset value. Journal of Marketing Research, 43(2), 195-203.

292. Lin, H., \& Wang, Y. (2006). An examination of the determinants of customer loyalty in mobile commerce contexts. Information \& Management, 43 (3), 271-282.

293. Lind, E., \& Tyler, T. (1988). The Social Psychology of Procedural Justice. New York: Plenum.

294. Lovelock, C. (1991). Services Marketing. Englewood Cliffs, NJ: Prentice Hall.

295. Lovelock, C. H. (1983). Classifying services to gain strategic marketing insights. Journal of Marketing, 9-20.

296. Lovelock, C. H. (1983). Classifying Services to Gain Strategic Marketing Insights. Journal of Marketing, 47, 9-20. .

297. Mandják, T. (1995). Gondolatok a projekt marketing kapcsán. Marketing \& Menedzsment, 29(4), 41-44.

298. Mano, H., \& Oliver, R. (1993). Assessing the Dimensionality and Structure of the Consumption Experience: Evaluation, Feeling, and Satisfaction. Journal of Consumer Research, 451-67. 
299. Marián, B. (2001). A nagyvárosi önkormányzatok "szolgáltatásainak" megítélése. Marketing \& Menedzsment, 35(1), 62-65.

300. Martin, C. L., \& Bennett, N. (1996). The role of justice judgments in explaining the relationship between job satisfaction and organizational commitment. Group \& Organization Management, 21(1), 84-104.

301. Masterson, S. S., Lewis, K., Goldman, B. M., \& \& Taylor, M. S. (2000). Integrating justice and social exchange: The differing effects of fair procedures and treatment on work relationships. Academy of Management journal, 43(4), 738-748.

302. Matthing, J., Sandén, B., \& Edvardsson, B. (2004). New service development: learning from and with customers. International Journal of Service Industry Management, 15(5), 479-498.

303. McColl-Kennedy, J. R., \& Sparks, B. A. (2003). Application of fairness theory to service failures and service recovery. Journal of Service Research, 5(3), 251-266.

304. McCollough, M., Berry, L., \& Yadav, M. (2000). An empirical investigation of customer satisfaction after service failure and recovery. Journal of Service Research; 3(2), 121-37.

305. McFarlin, D. B., \& Sweeney, P. D. (1992). Distributive and procedural justice as predictors of satisfaction with personal and organizational outcomes. Academy of management Journal, 35(3), 626-637.

306. McSorley, C., Padilla, A. J., \& Williams, M. (April 2003). Switching costs- Economic Discussion Paper 5: Part one: Economic models and policy. Office of Fair Trading, Department of Trade and Industry.

307. Mihály, N., Mészáros, A., Kovács, I. É., Madarász, I., \& Horváth, C. (2014). Pénzügyi attitűd és a "külsőbelső kontroll" összefüggésrendszere. Vezetéstudomány, 45(10)

308. Mikulás, G. (1998). Forráskihelyezés információs és könyvtári szolgáltatásokban. Vezetéstudomány, 29(3), 36-42.

309. Mills, P. K., \& Morris, J. H. (1986). Clients as "partial" employees of service organizations: Role development in client participation, . Academy of management review, 11(4), 726-735.

310. Mitchell, M., Taylor, R., \& Tanyel, F. (1997). Product elimination decisions: A comparison of consumer and industrial products. Journal of Marketing Management, 7(1), 44-55.

311. Mitev, A., \& Sajtos, L. (2007). SPSS kutatási és adatelemzési kézikönyv. Alinea Kiadó.

312. Molm, L. D., Takahashi, N., \& Peterson, G. (2000). Risk and trust in social exchange: An experimental test of a classical proposition. American Journal of Sociology, 105(5), 1396-1427.

313. Montgomery, D., Moore, M., \& Urbany, J. (2005). Reasoning about competitive reactions: evidence from executives. Marketing Science, 24, 138-149., 138-149.

314. Moorman, C., Zaltman, G., \& Deshpandé, R. (1992). Relationships Between Providers and Users of Marketing Research: The Dynamics of Trust Within and Between. Journal of Marketing Research, 29., 314-328.

315. Moorman, R. H., Niehoff, B. P., \& Organ, D. W. (1993). Treating employees fairly and organizational citizenship behavior: Sorting the effects of job satisfaction, organizational commitment, and procedural justice. Employee responsibilities and rights journal, 6(3), 209-225.

316. Morgan, M. S., \& Dev, C. S. (1994). An empirical study of brand switching for a retail service. Journal of Retailing, 70(3), 267-282.

317. Morgan, R., \& Hunt, S. (1994). The Commitment-Trust Theory of Relationship Marketing. Journal of Marketing, 58, 20-38. 
318. Mowen, J., \& Grove, S. (1983). Search Behavior, Price Paid and the Consumption Other: An Equity Theory Analysis of Post-Purchase Satisfaction. In R. Day, \& H. (. Hunt, International Fare in Consumer Satisfaction and Complaining Behavior (pp. 57-63.). Bloomington, IN: Indiana University Press.

319. Murray, K. B. (1991). A test of services marketing theory: consumer information acquisition activities. Journal of Marketing, 10-25.

320. Nemeskéri, Z. (1999). A turisztikai termék/szolgáltatás vásárlásának jellemzői. Marketing \& Menedzsment, 33(3-4), 20-24.

321. Nemzeti Média és Hírközlési Hatóság (NMHH). (2013). Telecommunication Service Usage Among the Residential Segment, $\quad 2013 . \quad$ Retrieved $06 \quad 19, \quad 2014, \quad$ from http://nmhh.hu/dokumentum/162756/lakossagi_tavkozles_2013.pdf

322. Németh, E. (1999). Pénzügyi szolgáltatások és fogyasztói érdekvédelem. Marketing \& Menedzsment, 33(1), 36-38.

323. Németh, G. (1995). Verseny a pénzügyi szolgáltatások piacain. Vezetéstudomány, 26(10), 47-55.

324. Neslin, S., Gupta, S., Kamakura, W., Lu, J., \& Charlotte H., M. (2006). Defection Detection: Measuring and Understanding the Predictive Accuracy of Customer Churn Models. Journal of Marketing Research, 43, 204-211.

325. Nijssen, E. J., Hillebrand, B., Vermeulen, P. A., \& Kemp, R. G. (2006). Exploring product and service innovation similarities and differences. International Journal of Research in Marketing, 23(3), 241-251.

326. Nobelprize.org. (2017). Nobelprize.org. Retrieved $04 \quad 07, \quad 2017$, from http://www.nobelprize.org/nobel_prizes/economic-sciences/laureates/2000/heckman-facts.html

327. Noordweier, T., John, G., \& Nevin, J. (1990). Performance outcomes of purchasing arrangements in industrial buyer-vendor relationships. Journal of Marketing, 54, 80-93.

328. O’brien, R. M. (2007). A caution regarding rules of thumb for variance inflation factors. Quality \& Quantity, 41(5), 673-690.

329. OECD. (2000). Agricultural Policies in OECD Countries: Monitoring and Evaluation 2000: Glossary of Agricultural Policy Terms.

330. Oh, H. C. (1995). An empirical study of the relationship between restaurant image and customer loyalty . Doctoral dissertation, Virginia Tech.

331. Oliver, R. L. (1980). A Cognitive Model of the Antecedents and Consequences of Satisfaction Decisions. Journal of Marketing Research, 460-69.

332. Oliver, R. L. (1997). Satisfaction: A behavioral perspective on the consumer. New York: McGraw-Hill.

333. Oliver, R. L. (1997). Satisfaction: A behavioral perspective on the consumer. Boston: Irwin McGraw-Hill.

334. Oliver, R. L., \& DeSarbo, W. S. (1988). Response Determinants in Satisfaction Judgments. Journal of Consumer Research, 495-507.

335. Oliver, R., \& Swan, J. (1989). Consumer Perceptions of Interpersonal Equity and Satisfaction in Transactions: A Field Survey Approach. Journal of Marketing, 53, 21-35.

336. Osman, P. (1997). A pénzintézetek és a bizalom. Marketing \& menedzsment, 31(1), 9-16.

337. Ostrom, A. L., Parasuraman, A., Bowen, D. E., Patricio, L., Voss, C. A., \& Lemon, K. (2015). Service research priorities in a rapidly changing context. Journal of Service Research, 18(2), 127-159.

338. Palmer, A. (1998). Principles of services marketing. London: MCGrow-Hill. 
339. Pandurics, A., \& Pusztai, J. (2006). MPL : Új márka a logisztikai piacon. Marketing \& Menedzsment, 40(5-6), 94-105.

340. Papp, I. (1995). A szolgáltatásmarketing sajátosságai és a marketingmix. Vezetéstudomány, 26(10), 31-40.

341. Papp, K., \& Rózsa, A. (2003). Szolgáltatásminőség elméletben és gyakorlatban. Marketing \& Menedzsment, 37(5), 4-13.

342. Parasuraman, A., Berry, L. L., \& Zeithaml, V. A. (1991). Refinement and reassessment of the SERVQUAL scale. Journal of Retailing, 67(4), 420-450.

343. Parasuraman, A., Zeithaml, V., \& Berry, L. (1985). A Conceptual Model of Service Quality and its Implications for Future Research. Journal of Marketing, 49, 41-50.

344. Párkányi, P. (1996). Gondolatok a banki szolgáltatások minőségéről. Marketing \& menedzsment, 30(6), $56-64$.

345. Pásztor, M. (2008). A magyar közszolgáltatások stratégiai problémái. Vezetéstudomány, 39(7-8), 2-13. .

346. Pawar, K. S., Beltagui, A. B., \& Riedel, J. C. (2009). The PSO triangle: designing product, service and organization to create value. International Journal of Operations and Production Management, 29(5), 468- 493 .

347. Penrose, E. T. (1959). The Theory of the Growth of the Firm. USA: Oxford University Press.

348. Pfisterer, L., \& Roth, S. (2015). Customer usage processes: A conceptualization and differentiation. Marketing Theory.

349. Ping, R. A. (1993). The effects of satisfaction and structural constraints on retailer exiting, voice, loyalty, opportunism, and neglect. Journal of Retailing, 69(3), 320-352.

350. Ping, R. A. (1997). Voice in business-to-business relationships: Cost-of-exit and demographic antecedents. Journal of Retailing, 73(2), 261-281.

351. Pintér, É. (2002). Kockázatkezelés a bankbiztosításban. Vezetéstudomány, 33(7-8), 72-77.

352. Pintér, É. (2004). Értékteremtés a banki szolgáltatásban. Vezetéstudomány, 35(2), 18-23.

353. Piskóti, I. (2008). Elégedettség-és értékorientált ügyfélmenedzsment-modell keretei. Miskolc: Marketingkaleidoszkóp, Miskolc Egyetem-Gazdaságtudományi Kar Marketing Intézet.

354. Prahalad, C. K., \& Ramaswamy, V. (2004). Co-creation experiences: The next practice in value creation. Journal of interactive marketing, 18(3), 5-14.

355. Prince, J., \& Greenstein, S. (2011). Does Service Bundling Reduce Churn? Journal of Economics \& Management Strategy, 23(4), 839-875.

356. Puhani, P. (2000). The Heckman Correction for sample selection and its critique. Journal of Economic Surveys. 14 (1), 53-68.

357. Putsis, W. J., \& Bayus, B. (2001). An empirical analysis of firms' product line decisions. Journal of Marketing Research, 38, 110-118.

358. Ramírez, R., \& Richardson, D. (2005). Measuring the impact of telecommunication services on rural and remote communities. Telecommunications Policy, 29(4), 297-319.

359. Ranaweera, C., \& Prabhu, J. (2003). The influence of satisfaction, trust and switching barriers on customer retention in a continuous purchasing setting. . International Journal of Service Industry Management, 14(4), 374-395.

360. Reichheld. (2003). One Number You Need to Grow. Harvard Business Review. 
361. Reichheld, F. F., \& Sasser Jr, W. E. (1989). Zero defections: Quality comes to services. Harvard Business Review, 68(5), 105-111.

362. Reinganum, J. F. (1989). The timing of innovation: Research, development, and diffusion. In R. Schmalensee, \& R. Willig, Handbook of industrial organization, 1 (pp. 849-908.). Amsterdam: North Holland.

363. Rekettye, G., \& Pintér, É. (2006). Internetoldalak értékelése: Autómárkák, kormányzati szevezetek, kereskedelmi bankok. Marketing \& Menedzsment, 40(1), 15-21.

364. Rekettye, G., Szücs, K., \& Hetesi, E. (2002). A szolgáltatásminőség Mérése-Hallgatói Elégedettség a Pécsi Tudományegyetemen. 152-167

365. Risselada, H., Verhoef, P., \& Bijmolt, T. (2010). Staying Power of Churn Prediction Models. Journal of Interactive Marketing.

366. Rogers, E. M. (1985). Diffusion of Innovations. 3rd ed. New York: The Free Press.

367. Roland Berger. (2017, 06 28). Roland Berger. Retrieved from http://www.rolandberger.at/media/pdf/Roland_Berger_Studie_CEE_in_2020_20101201.pdf

368. Rosegger, G., \& Baird, R. (1987). Entry and exit of makes in the automobile industry, 1895-1960: An international comparison. OMEGA International Journal of Management Science, 15(2), , 93-102.

369. Rothe, J. (1970). The product elimination decision. MSU Business Topics, 18, 45-52.

370. Ruebeck, C. (2002). Inter-firm competition, intra-firm cannibalisation and product exit in the market for computer hard disk drives. Economic and Social Review 33, 119-131.

371. Rust, R. (1998). What is the domain of service research? Journal of Service Research, 1(2), 107-107.

372. Rust, R. T., Simester, D., Brodie, R. J., \& Nilikant, V. (1995). Model Selection Criteria: An Investigation of Relative Accuracy, Posterior Probabilities, and Combinations of Criteria. Management Science, 41(2), 322-333.

373. Rust, R., \& Zahorik, A. (1993). Customer Satisfaction, Customer Retention, and Market Share. Journal of Retailing, 69, 193-215.

374. Sabzevari, H., Soleymani, M., \& Noorbakhsh, E. (2007). A comparison between statistical and data mining methods for credit scoring in case of limited available data. In Proceedings of the 3rd CRC Credit Scoring Conference. Edinburgh, UK.

375. Salamon, M. (2011). A TQM alkalmazhatósága a közszférában. Vezetéstudomány, 42(5), 57-64. .

376. Saunders, J., \& Jobber, D. (1994). Product replacement: Strategies for simultaneous product deletion and launch. Journal of Product Innovation Management, 17(5), 433-450.

377. Schumpeter, J. A. (1934). The Theory of Economic Development. Harvard Economic Studies: Cambridge Mass.

378. Schwartz, K. (2006). Szolgáltató egyetem a tanuló társadalomban - termékfejlesztés felsőfokon. Vezetéstudomány, 37(5), 20-25.

379. Sharma, N., \& Patterson, P. (2000). Switching costs, alternative attractiveness and experience as moderators of relationship commitment in professional consumer services. International Journal of Service Industry Management,11(5), 470-90. 
380. Sharma, N., Patterson, P., Cicic, M., \& Dawes, P. (1997). A contingency model of relationship commitment for professional consumer services. Proceedings of the 26th EMAC Conference, Warwick, May 20-23.

381. Shostack, G. L. (1977). Breaking free from product marketing. The Journal of Marketing, 73-80.

382. Shostack, G. L. (1984). Designing Services That Deliver. Harvard Business Review, 62, 133-139.

383. Shostack, G. L. (1987). Service Positioning Through Structural Change. Journal of Marketing, 51, 34-43.

384. Simay, A. (2014). A fogyasztói elégedettség, a fogyasztói bizalom és a fogyasztói lojalitás összefüggéseinek vizsgálata a magyar mobil telekommunikációs szolgáltatások piacán. Doctoral dissertation, Budapesti Corvinus Egyetem.

385. Simay, A. E. (2012). A fogyasztói lojalitás előzményei a magyar mobiltelefonos szolgáltatási piacon-A bizalom szerepe (Antecedents of the consumer loyalty in the Hungarian telecommunication market-the role of trust). Vezetéstudomány/Budapest Management Review 43(4), 48-61.

386. Singh, J. (1988). Consumer complaint intentions and behavior: definitional and taxonomical issues. Journal of Marketing, 93-107.

387. Smith, A. K., Bolton, R. N., \& Wagner, J. (1999). A model of customer satisfaction with service encounters involving failure and recovery. Journal of Marketing Research, 356-372.

388. Smith, T. J., \& McKenna, C. M. (2013). A comparison of logistic regression pseudo R2 indices. Multiple Linear Regression Viewpoints, 39(2), 17-26.

389. Solomon, M. R., Surprenant, C., Czepiel, J. A., \& Gutman, E. G. (1985). A Role Theory Perspective on Dynamic Interactions: The Service Encounte. Journal of Marketing, 41 (1), 99-111.

390. Somogyi, A. (2006). Reformérett közügyek : Public management : Új irányok, átalakuló cél- és eszközrendszer. Vezetéstudomány, 37(1), 79-86.

391. Somogyi, I. (2013). Az online fogyasztói elégedettségmérés hatása a vállalatok versenyképességére (Effect of the online-customer satisfaction's measurement to the corporate's competitiveness). Vezetéstudomány, 44(3), 49-60.

392. Somosi, Á., \& Kolos, K. (2014). The success-factors of service elimination. CINet Conference (pp. 832844.). ISBN 978-90-77360-17-0.

393. Somosi, Á., \& Kolos, K. (2017). The role of economic and psychological costs in service elimination. Vezetéstudomány/Budapest Management Review, 48(5), 14-23.

394. Spohrer, J., Kwan, S. K., \& Fisk, R. P. (2014). Marketing: A Service Science and Arts Perspective. In e. Roland T. Rust and Ming-Hui Huang, Handbook of Service Marketing Research (pp. 489-526.). Northampton, MA: Edward Elgar Publishing.

395. Srinivasan, S. S., Anderson, R., \& Ponnavolu, K. (2002). Customer loyalty in e- commerce: An exploration of its antecedents and consequences. Journal of Retailing , 78 (1), 41-50.

396. Stavins, J. (1995). Model entry and exit in a differentiated-product industry: The personal computer market. Review of Economics and Statistics, 77(4), 571-584.

397. Strandvik, T., Holmlund, M., \& Edvardsson, B. (2012). Customer needing: a challenge for the seller offering. Journal of Business \& Industrial Marketing, 27(2), 132-141.

398. Surprenant, C. F., \& Solomon, M. R. (1987). Predictability and personalization in the service encounter. Journal of Marketing, 86-96. 
399. Szabó, Z. R., \& Vida, G. (2009). Szolgáltató központok Magyarországon. Vezetéstudomány, 40(4), 2842. .

400. Székely, Á. (2007). Teljesítménymérés és -értékelés a magyarországi vízmü-szektorban. Vezetéstudomány, 38(11), 46-59.

401. Szilágyiné Fülöp, E. (2012). A gazdasági kamarák szolgáltatásainak szerepe a vállalakozásfejlesztésben. Vezetéstudomány, 43, 90-96.

402. Szüle, B. (2006). Pénzügyi konglomerátumok és bankbiztosítás : Új modellek a pénzügyi szolgáltatási szektorokban. Vezetéstudomány, 37(2), 45-54.

403. Takács, E. (2015). A közszolgálati szervezetek értékelési módszereinek osztályozása. Vezetéstudomány, $46(3) ., 45-56$.

404. Takács, J. (1998). Piaci munka a bankban. Marketing \& menedzsment, 32(4), 56-58.

405. Tax, S. S., \& Brown, S. W. (1998). Recovering and learning from service failure. MIT Sloan Management Review, 40(1), 75-88.

406. The World Bank. (2017, 04 03). The World Bank. Retrieved from: http://data. worldbank.org/indicator/NV.SRV.TETC.ZS?end=2014\&start=2014\&view=map

407. Thibaut, J., \& Walker, L. (1975). Procedural Justice: A Psychological Analysis. Hillsdale, NJ: Erlbaum.

408. Thomas, J. S., Reinartz, W., \& Kumar, V. (2004). Getting the most out of all your customers. Harvard Business Review, 82(7-8), 116-23.

409. Thompson, V. (1965). Bureaucracy and innovation. Administrative Science Quarterly, 10, 1-20.

410. Tyler, R. (1987). Conditions Leading to Value-Expressive Effects of Procedural Justice: A Test of Four Models. Journal of Personality and Social Psychology Research, 52, 333-344.

411. Tyler, R., \& Bies, R. (1989). Beyond Formal Procedures: The Interpersonal Context of Procedural Justice. In Applied Psychology and Organizational Settings (pp. 77-98). Hillsdale, NJ: Erlbaum.

412. Utterback, J. (1994). Mastering the Dynamics of Innovation. Boston: Harvard Business School Press.

413. Vágási, M. (1999). A képzés és a karbantartás szerepe az ipari marketingben. Marketing \& Menedzsment, $33(2), 66-70$.

414. Vályogos, G. (1994). Marketing a szolgáltatásokban. Vezetéstudomány, 3, 36-39. .

415. Van Den Ende, J. (2003). Modes of governance of new service development for mobile networks: A life cycle perspective. Research policy, 32(8), 1501-1518.

416. Ványai, J. (1996). A marketingszolgáltatások helyzete. Vezetéstudomány, 27(2), 21-28.

417. Ványai, J. (1997). Pénzügyi szolgáltatások és az Európai Unióhoz való csatlakozás. Vezetéstudomány, 28(7-8), 31-39.

418. Várady, Z. (1994). Szekunder-szolgáltatások szerepe a vállalatok kínálatában. Vezetéstudomány, 7, 4252. .

419. Varga, N., \& Fojtik, J. (2004). Bankmarketing a vállalati üzletágban. Marketing \& Menedzsment, 38(3), 49-59.

420. Vargo, S. L., \& Lusch, R. F. (2004). Evolving to a new dominant logic for marketing. Journal of Marketing, 68(1), 1-17.

421. Vargo, S. L., \& Lusch, R. F. (2004). The four service marketing myths: remnants of a goods-based, manufacturing model. Journal of Service Research, 6(4), 324-335. 
422. Vargo, S. L., \& Lusch, R. F. (2008). Service-dominant logic: continuing the evolution. Journal of the Academy of Marketing Science, 36(1), 1-10.

423. Vargo, S. L., \& Lusch, R. F. (2016). Institutions and axioms: an extension and update of servicedominant logic. Journal of the Academy of Marketing Science, 44(1), 5-23.

424. Vargo, S. L., Wieland, H., \& Akaka, M. A. (2015). Innovation through institutionalization: A service ecosystems perspective. Industrial Marketing Management, 44., 63-72.

425. Venkatesan, M., \& Anderson, B. (1985). Time Budgets and Consumer Services, " Pp, 52-55 in Thomas M, Bloch, Gregory D Upah, and Valerie Zeithaml (eds,). Services Marketing in a Changing Environment. Chicago: American Marketing Association.

426. Venkatesan, R., \& Kumar, V. (2004). A customer lifetime value framework for customer selection and resource allocation strategy. Journal of Marketing, 68(4), 106-125.

427. Veres, Z. (1995). Minőségi értékítélet-kutatás a projekttípusú ipari szolgáltatásokban. Marketing \& Menedzsment, 29(4), 37-40.

428. Veres, Z. (1998). Dolgozzon a vevő! : "Aktív ügyfél"-politika a szolgáltatásmarketingben. Marketing \& Menedzsment, 32(5), 41-44.

429. Veres, Z. (1998). Találkozások a frontvonalban. Vezetéstudomány, 29(6), 12-17.

430. Veres, Z. (2008). Egy régi mánia : A gap-modell az elégedettség-kutatásban. Marketing \& Menedzsment, 42(2), 4-17.

431. Veres, Z., \& Sajtos, L. (2011). Észlelt kockázat, érték és projektkompetenciák. Vezetéstudomány, 42 (1), 41-51.

432. Verhoef, P. (2003). Understanding the Effect of Customer Relationship Management Efforts on Customer Retention and Customer Share Development. Journal of Marketing, 67., 30-45.

433. Wang, Y. S., Wu, S. C., Lin, H. H., \& Wang, Y. Y. (2011). The relationship of service failure severity, service recovery justice and perceived switching costs with customer loyalty in the context of e-tailing. International Journal of Information Management, 31(4), 350-359.

434. Wangenheim, F. V. (2004). Predicting Usage Intensity and Upgrading Behavior of Service Customers: A Model for Lifetime Value Estimation at Early Relationship Stages.

435. Webster Jr, F. E. (1992). The changing role of marketing in the corporation. Journal of Marketing, 1-17.

436. Westbrook, R. A. (1987). Product/consumption-based affective responses and postpurchase processes. Journal of Marketing Research, 258-270.

437. Westbrook, R., \& Oliver, R. (1991). The Dimensionality of Consumption Emotion Patterns and Consumer Satisfaction. Journal of Consumer Research, 84-91.

438. Wirtz, J., \& Lovelock, C. (2016). Services marketing: people, technology, strategy. USA: World Scientific Publishing Co Inc.

439. Wirtz, J., \& Mattila, A. S. (2004). Consumer responses to compensation, speed of recovery and apology after a service failure. International Journal of Service Industry Management, 15(2), 150-166.

440. Wu, S. D., Aytac, B., Berger, R. T., \& Armbruster, C. A. (2006). Managing short life-cycle technology products for Agere Systems. Interfaces, 36(3), 234-247. 
441. Yelmo, J. C., del Álamo, J. M., Sienel, J., Drewniok, M., Ordás, I., \& McCallum, K. (2007). User-driven service lifecycle management-adopting internet paradigms in telecom services. In ICSOC, 7 (pp. 342352.).

442. Yi, Y. (1990). A critical review of consumer satisfaction. In V. A. Zeithaml, Review of Marketing (pp. 68-123.). Chicago: American Marketing Association.

443. Zeithaml, V. A. (1996). Service marketing. New York: McGraw-Hill.

444. Zeithaml, V. A., Brown, S. W., Bitner, M., \& Salas, J. (2014). Profiting from services and solutions: what product-centric firms need to know. New York: Business Expert Press.

445. Zeithaml, V. A., Parasuraman, A., \& Berry, L. L. (1985). Problems and strategies in services marketing. Journal of Marketing, 33-46.

446. Zeithaml, V., Berry, L., \& Parasuraman, A. (1996). The behavioral consequences of service quality. Journal of Marketing, 31-46.

447. Zimmermann, E. W. (1951). World resources and industries. New York: Harper and Row.

448. Zsótér, B., Béres, D., \& Németh, E. (2015). A magyar fiatalok jellemzése pénzügyi attitüdjeik és magatartásuk mentén-Vizsgálat a felsőoktatásban tanulók pénzügyi attitüdjeiről és magatartásáról. Vezetéstudomány/Budapest Management Review, 46(6), 70-80. 


\section{FÜGGELÉK}

\section{F ÜGGELÉK: ESETTANULMÁNY: MÉLYINTERJÚ GUIDE}

Kérem, idézzen fel egy olyan esetet, amikor úgy döntött, hogy egy vagy több jelenlegi szolgáltatását kivezeti.

- Melyek voltak a szolgáltatáskivezetés okai?

- Mit gondol, ezeken kívül voltak külső mozgatórugók is? Hogyan tervezte meg a kivezetés folyamatát?

- Volt bármilyen korlát, amely akadályozta abban, hogy véghezvigye a projektet?

- Melyek voltak a szolgáltatáskivezetési folyamat lépései? Folyamatos interakcióban volt a vállalat az ügyfelekkel?

- Van a vállalatnak szolgáltatáskivezetéssel kapcsolatos meghatározott stratégiája?

- Melyek voltak a szolgáltatáskivezetés következményei? Sikerült a tervezett célokat elérni a projektben?

- Sikeres volt a szolgáltatáskivezetés? Az Ön számára a siker mit jelent pontosan? A vállalat rendelkezik a szolgáltatáskivezetést minősítő rendszerrel?

\section{FÜGGELÉK: 1. TANULMÁNY: KÍSÉRLETI MÓDSZERTANI KÉRDÖÍV}

Az 1. tanulmányban 4 forgatókönyvet használtunk, amelyeket ugyanaz a 15 kérdés követte, a függő változókra gyakorolt hatás mérése érdekében. A kérdőíveket magyarul kérdeztük le.

- 1. Szcenárió:

Kedves Válaszadó! A Budapesti Corvinus Egyetem kutatásának része a következö kérdőív, melynek kitöltése teljesen anonim és csupán néhány percet vesz igénybe. Arra kérünk, hogy akkor töltsd ki a kérdőívet, ha a vezetékneved A-F betüvel kezdődik. Ez a kérdőív randomizálását szolgálja, nem tudunk senki beazonosítani ezen információ alapján. Válaszaidat elöre is köszönjük!

A mobilszolgáltatód megszünteti a mobil csomagot, amire előfizettél. A váltás elött a szolgáltató felhív, hogy értesítsen erről és segítsen választani az új előfizetések közül. Jelzed a telefonos ügyintézőnek, hogy nem szeretnéd megszüntetni az előfizetésed, mert tökéletes számodra. Az ügyintéző a jelenlegi előfizetésednél kedvezőbb havidijjú csomagot ajánl, több internettel és alacsonyabb percdíjjal. A hívás után egy héttel megérkezik a levél értesítés is a váltásról. 
- 2. Szcenárió:

Kedves Válaszadó! A Budapesti Corvinus Egyetem kutatásának része a következő kérdőív, melynek kitöltése teljesen anonim és csupán néhány percet vesz igénybe. Arra kérünk, hogy akkor töltsd ki a kérdőívet, ha a vezetékneved G-L betüvel kezdődik. Ez a kérdőív randomizálását szolgálja, nem tudunk senki beazonosítani ezen információ alapján. Válaszaidat elöre is köszönjük!

A mobilszolgáltatód megszünteti a mobil csomagot, amire előfizettél. A váltás előtt a szolgáltató felhív, hogy értesítsen erről és segítsen választani az új előfizetések közül. Jelzed a telefonos ügyintézőnek, hogy nem szeretnéd megszüntetni az előfizetésed, mert tökéletes számodra. Az ügyintéző a jelenlegi előfizetésednél magasabb havidíjú csomagot ajánl, kevesebb internettel és magasabb percdíjjal. A hívás után egy héttel megérkezik a levél értesítés is a váltásról.

- 3. Szcenárió:

Kedves Válaszadó! A Budapesti Corvinus Egyetem kutatásának része a következő kérdőív, melynek kitöltése teljesen anonim és csupán néhány percet vesz igénybe. Arra kérünk, hogy akkor töltsd ki a kérdőívet, ha a vezetékneved M-R betűvel kezdődik. Ez a kérdőív randomizálását szolgálja, nem tudunk senki beazonosítani ezen információ alapján. Válaszaidat elöre is köszönjük!

A mobilszolgáltatód megszünteti a mobil csomagot, amire előfizettél. A szolgáltató levélben értesít erről, de nem emlékszel, hogy megkaptad volna a levelet, ezért váratlanul ér a hír. Amikor a telefonos ügyintéző felhív, jelzed neki, hogy nem szeretnéd megszüntetni az előfizetésed, mert tökéletes számodra. Az ügyintéző a jelenlegi előfizetésednél kedvezőbb havidíjú csomagot ajánl, több internettel és alacsonyabb percdíjjal.

- 4. Szcenárió:

Kedves Válaszadó! A Budapesti Corvinus Egyetem kutatásának része a következő kérdőív, melynek kitöltése teljesen anonim és csupán néhány percet vesz igénybe. Arra kérünk, hogy akkor töltsd ki a kérdőívet, ha a vezetékneved S-Z betüvel kezdődik. Ez a kérdőív randomizálását szolgálja, nem tudunk senki beazonosítani ezen információ alapján. Válaszaidat elöre is köszönjük!

A mobilszolgáltatód megszünteti a mobil csomagot, amire előfizettél. A szolgáltató levélben értesít erről, de nem emlékszel, hogy megkaptad volna a levelet, ezért váratlanul ér a hír. Amikor a telefonos ügyintéző felhív, jelzed neki, hogy nem szeretnéd megszüntetni az 
előfizetésed, mert tökéletes számodra. Az ügyintéző a jelenlegi előfizetésednél magasabb havidíjú csomagot ajánl, kevesebb internettel és magasabb percdíjjal.

- Az egyes forgatókönyvekhez rendelt kérdések a következőek:

\begin{tabular}{|l|l|l|l|l|l|}
\hline & 1 & 2 & 3 & 4 & 5 \\
\hline Q1 A szolgáltató reakcióját megfelelönek tartom. & & & & & \\
\hline $\begin{array}{l}\text { Q2 Elégedett vagyok a szolgáltató által nyújtott } \\
\text { ajánlattal. }\end{array}$ & & & & & \\
\hline Q3 A szolgáltató meghaladja az elvárásaimat. & & & & & \\
\hline $\begin{array}{l}\text { Q4 A szolgáltató közel áll az általam legjobbnak tartott } \\
\text { mobilszolgáltatóhoz. }\end{array}$ & & & & & \\
\hline $\begin{array}{l}\text { Q5 A szolgáltatót pozitívan fogom feltüntetni mások } \\
\text { előtt. }\end{array}$ & & & & & \\
\hline $\begin{array}{l}\text { Q6 Ajánlanám másoknak a szolgáltatót, aki a } \\
\text { tanácsomat kéri. }\end{array}$ & & & & & \\
\hline $\begin{array}{l}\text { Q7 A szolgáltatónál maradnék az elkövetkezendö } \\
\text { néhány évben. }\end{array}$ & & & & & \\
\hline Q8 Elfogadnám a szolgáltató ajánlatát. & & & & & \\
\hline Q9 Szolgáltatót váltanék a képzelt eset miatt. & & & & & \\
\hline Q10 Másoknak is elmondanám, hogy mi történt velem. & & & & & \\
\hline $\begin{array}{l}\text { Q11 Panaszt tennék a szolgáltatónál a képzelt eset } \\
\text { miatt. }\end{array}$ & & & & & \\
\hline Q12 Örülök, hogy a szolgáltató ügyfele lehetek. & & & & \\
\hline Q13 Megbízom ebben a szolgáltatóban. & & & & \\
\hline $\begin{array}{l}\text { Q14 Megéri számomra a szolgáltató által nyújtott } \\
\text { szolgáltatót a képzelt eset után. }\end{array}$ & & & & & \\
\hline
\end{tabular}

\section{F ÜGGELÉK: 1. TANULMÁNY: BELSÖ ÉS KÜLSÖ ÉRVÉNYESSÉG KÉRDÖÍVE}

Az 1. tanulmányban 4 forgatókönyvet használtunk, amelyeket ugyanaz a 7 kérdés követte, a függő változókra gyakorolt hatás mérése érdekében. A kérdőíveket magyarul kérdeztük le.

- 1. Szcenárió:

Kedves Válaszadó! A Budapesti Corvinus Egyetem kutatásának része a következő kérdőív, melynek kitöltése teljesen anonim és csupán néhány percet vesz igénybe. Arra 
kérünk, hogy akkor töltsd ki a kérdőívet, ha a vezetékneved A-F betüvel kezdődik. Ez a kérdőív randomizálását szolgálja, nem tudunk senki beazonosítani ezen információ alapján. Válaszaidat elöre is köszönjük!

A mobilszolgáltatód megszünteti a mobil csomagot, amire előfizettél. A váltás előtt a szolgáltató felhív, hogy értesítsen erről és segítsen választani az új előfizetések közül. Jelzed a telefonos ügyintézőnek, hogy nem szeretnéd megszüntetni az előfizetésed, mert tökéletes számodra. Az ügyintéző a jelenlegi előfizetésednél kedvezőbb havidíjú csomagot ajánl, több internettel és alacsonyabb percdíjjal. A hívás után egy héttel megérkezik a levél értesítés is a váltásról.

- 2. Szcenárió:

Kedves Válaszadó! A Budapesti Corvinus Egyetem kutatásának része a következő kérdőív, melynek kitöltése teljesen anonim és csupán néhány percet vesz igénybe. Arra kérünk, hogy akkor töltsd ki a kérdöívet, ha a vezetékneved G-L betüvel kezdődik. Ez a kérdőív randomizálását szolgálja, nem tudunk senki beazonosítani ezen információ alapján. Válaszaidat elöre is köszönjük!

A mobilszolgáltatód megszünteti a mobil csomagot, amire előfizettél. A váltás előtt a szolgáltató felhív, hogy értesítsen erről és segítsen választani az új előfizetések közül. Jelzed a telefonos ügyintézőnek, hogy nem szeretnéd megszüntetni az előfizetésed, mert tökéletes számodra. Az ügyintéző a jelenlegi előfizetésednél magasabb havidíjú csomagot ajánl, kevesebb internettel és magasabb percdíjjal. A hívás után egy héttel megérkezik a levél értesítés is a váltásról.

- 3. Szcenárió:

Kedves Válaszadó! A Budapesti Corvinus Egyetem kutatásának része a következő kérdőív, melynek kitöltése teljesen anonim és csupán néhány percet vesz igénybe. Arra kérünk, hogy akkor töltsd ki a kérdőívet, ha a vezetékneved M-R betüvel kezdődik. Ez a kérdőív randomizálását szolgálja, nem tudunk senki beazonosítani ezen információ alapján. Válaszaidat elöre is köszönjük!

A mobilszolgáltatód megszünteti a mobil csomagot, amire előfizettél. A szolgáltató levélben értesít erről, de nem emlékszel, hogy megkaptad volna a levelet, ezért váratlanul ér a hír. Amikor a telefonos ügyintéző felhív, jelzed neki, hogy nem szeretnéd megszüntetni az előfizetésed, mert tökéletes számodra. Az ügyintéző a jelenlegi előfizetésednél kedvezőbb havidíjú csomagot ajánl, több internettel és alacsonyabb percdíjjal.

- 4. Szcenárió: 
Kedves Válaszadó! A Budapesti Corvinus Egyetem kutatásának része a következő kérdőív, melynek kitöltése teljesen anonim és csupán néhány percet vesz igénybe. Arra kérünk, hogy akkor töltsd ki a kérdőívet, ha a vezetékneved S-Z betüvel kezdődik. Ez a kérdőív randomizálását szolgálja, nem tudunk senki beazonosítani ezen információ alapján. Válaszaidat elöre is köszönjük!

A mobilszolgáltatód megszünteti a mobil csomagot, amire előfizettél. A szolgáltató levélben értesít erről, de nem emlékszel, hogy megkaptad volna a levelet, ezért váratlanul ér a hír. Amikor a telefonos ügyintéző felhív, jelzed neki, hogy nem szeretnéd megszüntetni az előfizetésed, mert tökéletes számodra. Az ügyintéző a jelenlegi előfizetésednél magasabb havidíjú csomagot ajánl, kevesebb internettel és magasabb percdíjjal.

- Az egyes forgatókönyvekhez rendelt kérdések a következőek:

\begin{tabular}{|l|l|l|l|l|l|}
\hline & 1 & 2 & 3 & 4 & 5 \\
\hline Q1 Anyagilag jobban járok az új ajánlattal. & & & & & \\
\hline Q2 Úgy érzem, hogy anyagi szempontból veszteség ér. & & & & & \\
\hline $\begin{array}{l}\text { Q3 Az eset után kétségek merülnek fel bennem a szolgáltató } \\
\text { megbízhatóságával kapcsolatban. }\end{array}$ & & & & & \\
\hline $\begin{array}{l}\text { Q4 Az esetet követóen úgy érzem, hogy a szolgáltató inkább } \\
\text { rugalmatlan az irányomban. }\end{array}$ & & & & & \\
\hline Q5 Értékelem a szolgáltató segítőkészségét. & & & & & \\
\hline Q6 Az esetet realisztikusnak tartom. & & & & & \\
\hline Q7 Ilyen eset előfordulhat a mindennapi életben. & & & & & \\
\hline
\end{tabular}

\section{FÜGGELÉK: 2. TANULMÁNY: KÍSÉRLETI MÓDSZERTANI KÉRDÖÍV}

Az 1. tanulmányban 8 forgatókönyvet használtunk, amelyeket ugyanaz a 17 kérdés követte, a függő változókra gyakorolt hatás mérése érdekében. A kérdöíveket angolul kérdeztük le.

\section{Bevezető szöveg}

Q0 Kedves Válaszadó! A Bécsi Gazdálkodástudományi Egyetem Ph.D. kutatást végez telekommunikációs szolgáltatásokkal kapcsolatban. A kérdőív kitöltése nagyjából 10 percet vesz igénybe. Az adatokat bizalmasan kezeljük és külső felekkel nem osztjuk meg. Kérem, válaszoljon az alábbi kérdésekre, hogy mennyire ért egyet az alábbi állításokkal (1- egyáltalán nem ért egyet; 5- teljes mértékben egyetért). Ha bármilyen kérdése felmerülne, kérjük a következő email címre írjon: agnes.somosi@uni-corvinus.hu. Válaszait elöre is köszönjük!

\section{Forgatókönyvek}


- 1. Szcenárió: A mobilszolgáltatód megszünteti a mobil csomagot, amire előfizettél., ami azt jelenti, hogy a jelenlegi előfizetésed feltételei a továbbiakban már nem lesznek elérhetőek. A mobilszolgáltató levélben értesít erről, amelyben új feltételeket ajánlanak számodra. A levél nem világos számodra, ezért úgy döntesz, hogy felhívod a mobilszolgáltatót. Többszöri hívás és hosszú várakozás után végre sikerül egy hozzáértő emberrel beszélned. Az ügyintézö barátságtalan és úgy tünik, hogy nem figyel oda az igényeidre, és a jelenlegi előfizetésednél összességében 10\%-kal drágább csomagot ajánl.

- 2. Szcenárió: A mobilszolgáltatód megszünteti a mobil csomagot, amire előfizettél., ami azt jelenti, hogy a jelenlegi előfizetésed feltételei a továbbiakban már nem lesznek elérhetőek. A mobilszolgáltató levélben értesít erről, amelyben új feltételeket ajánlanak számodra. A levél nem világos számodra, ezért úgy döntesz, hogy felhívod a mobilszolgáltatót. Többszöri hívás és hosszú várakozás után végre sikerül egy hozzáértő emberrel beszélned. Az ügyintéző barátságtalan és úgy tünik, hogy nem figyel oda az igényeidre, és a jelenlegi előfizetésednél összességében 10\%-kal kedvezőbb csomagot ajánl.

- 3. Szcenárió: A mobilszolgáltatód megszünteti a mobil csomagot, amire előfizettél., ami azt jelenti, hogy a jelenlegi előfizetésed feltételei a továbbiakban már nem lesznek elérhetőek. A mobilszolgáltató levélben értesít erről, amelyben új feltételeket ajánlanak számodra. A levél nem világos számodra, ezért úgy döntesz, hogy felhívod a mobilszolgáltatót. Többszöri hívás és hosszú várakozás után végre sikerül egy hozzáértő emberrel beszélned. Az ügyintéző barátságos és úgy tünik, hogy odafigyel az igényeidre, és a jelenlegi előfizetésednél összességében 10\%-kal drágább csomagot ajánl.

- 4. Szcenárió: A mobilszolgáltatód megszünteti a mobil csomagot, amire előfizettél., ami azt jelenti, hogy a jelenlegi előfizetésed feltételei a továbbiakban már nem lesznek elérhetőek. A mobilszolgáltató levélben értesít erről, amelyben új feltételeket ajánlanak számodra. A levél nem világos számodra, ezért úgy döntesz, hogy felhívod a mobilszolgáltatót. Többszöri hívás és hosszú várakozás után végre sikerül egy hozzáértő emberrel beszélned. Az ügyintéző barátságos és úgy tünik, hogy odafigyel az igényeidre, és a jelenlegi előfizetésednél összességében 10\%-kal kedvezőbb csomagot ajánl.

- 5. Szcenárió: A mobilszolgáltatód megszünteti a mobil csomagot, amire előfizettél., ami azt jelenti, hogy a jelenlegi előfizetésed feltételei a továbbiakban már nem lesznek elérhetőek. A mobilszolgáltató levélben értesít erről, amelyben új feltételeket ajánlanak számodra. A levél nem világos számodra, de a szolgáltató szerencsére felhív, hogy tájékoztasson a változásokról. Az ügyintéző barátságtalan és úgy tünik, hogy nem figyel 
oda az igényeidre, és a jelenlegi előfizetésednél összességében 10\%-kal drágább csomagot ajánl.

- 6. Szcenárió: A mobilszolgáltatód megszünteti a mobil csomagot, amire előfizettél., ami azt jelenti, hogy a jelenlegi előfizetésed feltételei a továbbiakban már nem lesznek elérhetőek. A mobilszolgáltató levélben értesít erről, amelyben új feltételeket ajánlanak számodra. A levél nem világos számodra, de a szolgáltató szerencsére felhív, hogy tájékoztasson a változásokról. Az ügyintéző barátságtalan és úgy tünik, hogy nem figyel oda az igényeidre, és a jelenlegi előfizetésednél összességében 10\%-kal kedvezőbb csomagot ajánl.

- 7. Szcenárió: A mobilszolgáltatód megszünteti a mobil csomagot, amire előfizettél., ami azt jelenti, hogy a jelenlegi előfizetésed feltételei a továbbiakban már nem lesznek elérhetőek. A mobilszolgáltató levélben értesít erről, amelyben új feltételeket ajánlanak számodra. A levél nem világos számodra, de a szolgáltató szerencsére felhív, hogy tájékoztasson a változásokról. Az ügyintéző barátságos és úgy tünik, hogy odafigyel az igényeidre, és a jelenlegi előfizetésednél összességében 10\%-kal drágább csomagot ajánl.

- 8. Szcenárió: A mobilszolgáltatód megszünteti a mobil csomagot, amire előfizettél., ami azt jelenti, hogy a jelenlegi előfizetésed feltételei a továbbiakban már nem lesznek elérhetőek. A mobilszolgáltató levélben értesít erről, amelyben új feltételeket ajánlanak számodra. A levél nem világos számodra, de a szolgáltató szerencsére felhív, hogy tájékoztasson a változásokról. Az ügyintéző barátságos és úgy tünik, hogy odafigyel az igényeidre, és a jelenlegi előfizetésednél összességében 10\%-kal kedvezőbb csomagot ajánl.

\section{Kérdések}

Q0 Kérem, válaszoljon az alábbi kérdésekre, hogy mennyire ért egyet az alábbi állításokkal (1- egyáltalán nem ért egyet; 5- teljes mértékben egyetért).

\begin{tabular}{|l|l|l|l|l|l|}
\hline & 1 & 2 & 3 & 4 & 5 \\
\hline Q1 A szolgáltató reakcióját megfelelónek tartom. & & & & & \\
\hline Q2 Elégedett vagyok a szolgáltató által nyújtott ajánlattal. & & & & & \\
\hline Q3 A szolgáltató meghaladja az elvárásaimat. & & & & & \\
\hline $\begin{array}{l}\text { Q4 A szolgáltató közel áll az általam legjobbnak tartott } \\
\text { mobilszolgáltatóhoz. }\end{array}$ & & & & & \\
\hline Q5 A szolgáltatót pozitívan fogom feltüntetni mások előtt. & & & & & \\
\hline $\begin{array}{l}\text { Q6 Ajánlanám másoknak a szolgáltatót, aki a tanácsomat kéri. } \\
\text { Q7 Ajánlanám ismeróseimnek, barátaimnak a szolgáltatót a képzelt } \\
\text { eset után. }\end{array}$ & & & & & \\
\hline
\end{tabular}




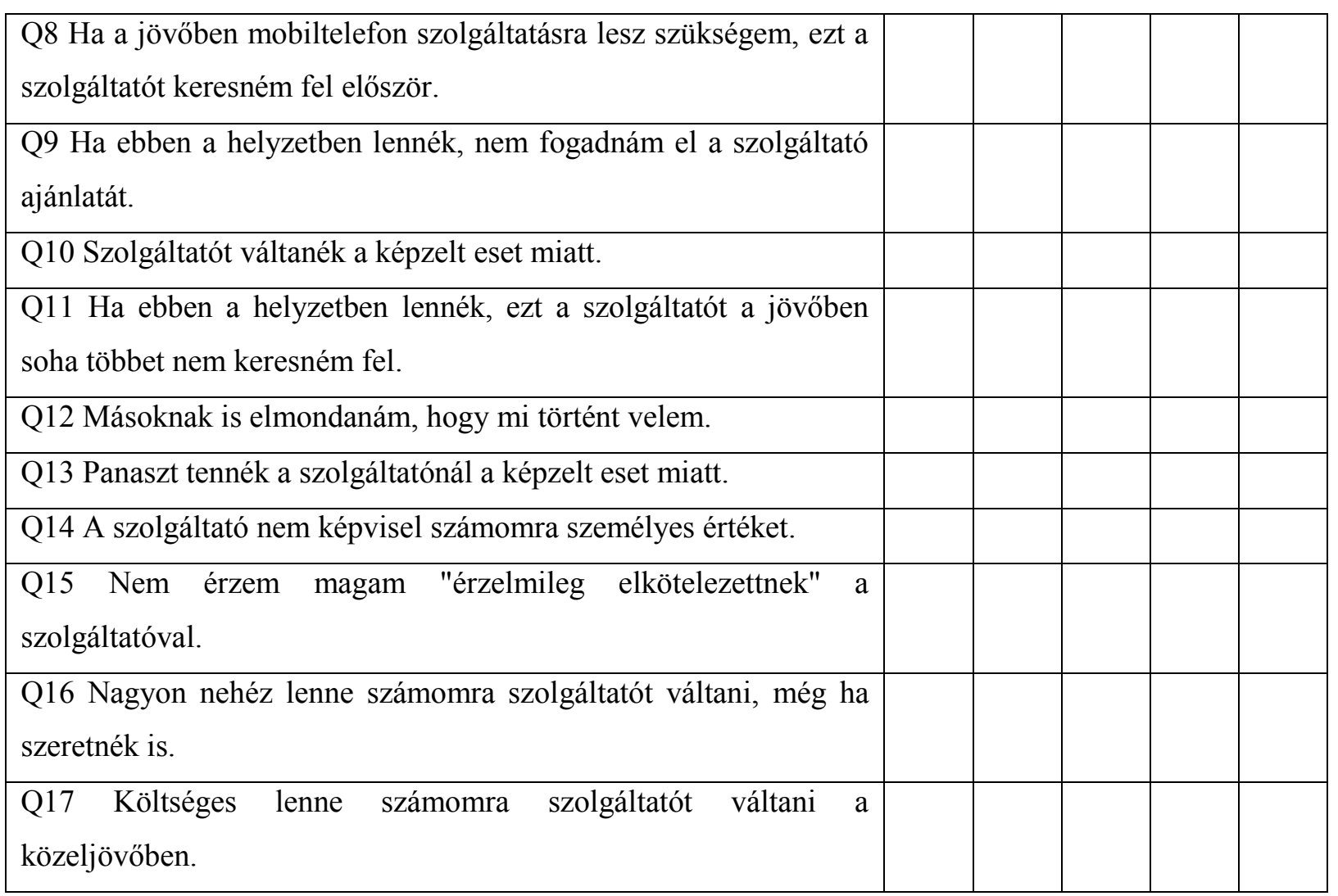

\section{Demográfia}

Q1 Mi az Ön neme?

- Férfi (1)

- Nő (2)

Q2 Hány éves?

Q3 Mi az Ön legmagasabb befejezett iskolai végzettsége?

- Középiskolánál kevesebb (1)

- Középiskola (2)

- Főiskola, diploma nélkül (3)

- 2 éves felsőfokú tanulmányok után kapható diploma (USA) (4)

- B.Sc. diploma (5)

- M.Sc. diploma (6)

- Ph.D. (7)

Q4 Milyen országból származik? 
Q5 Milyen nemzetiségü?

Q6 Milyen városban van a tartózkodási helye?

Q7 Mi a foglalkozása?

- Diák (1)

- Gyakornok (2)

- $\quad$ Kezdő szintü pozíció (3)

- $\quad$ Menedzser (4)

- $\quad$ Szenior menedzser (5)

- Igazgató (6)

- $\quad$ Elnök vagy CEO (7)

- Tulajdonos (8)

- Munkanélküli (9)

Q8 Milyen típusú szervezetnél dolgozik?

- $\quad$ For-profit (1)

- $\quad$ Non-profit (2)

- $\quad$ Kormányzat (3)

- $\quad$ Egészségügy (4)

- $\quad$ Oktatás (5)

- $\quad$ Egyéb (6)

Q9 A munkaadójának összes müködési területét beleszámítva, összesen hány alkalmazottja van a szervezetnek?

- $1(1)$

- 2-9 (2)

- $10-24(3)$

- $\quad 25-99(4)$

- $100-499(5)$

- $\quad 500-999(6)$

- $1000-4999(7)$

- $5000+(8)$

Q10 Mi az Ön családi állapota?

- Egyedülálló (1) 
- Kapcsolatban (2)

- Házas (3)

- $\quad$ Elvált (4)

Q11 Mi az Ön átlagos havi jövedelme (EUR)?

- $0-499(1)$

- $\quad 500-999(2)$

- $1000-1499(3)$

- $\quad 1500-1999(4)$

- $2000-2499$ (5)

- $\quad 2500-2999(6)$

- $\quad 3000-3499(7)$

- $\quad 3500-3999(8)$

- $\quad 4000-4499(9)$

- $4500-4999(10)$

- $\quad 5000+(11)$

\section{FÜGGELÉK: 2. TANULMÁNY: BELSŐ ÉS KÜLSÖ ÉRVÉNYESSÉG KÉRDÖÍVE}

Az 1. tanulmányban 8 forgatókönyvet használtunk, amelyeket ugyanaz a 12 kérdés követte, a függő változókra gyakorolt hatás mérése érdekében. A kérdőíveket angolul kérdeztük le.

\section{Bevezető szöveg}

Q0 Kedves Válaszadó! A Bécsi Gazdálkodástudományi Egyetem Ph.D. kutatást végez telekommunikációs szolgáltatásokkal kapcsolatban. A kérdőív kitöltése nagyjából 10 percet vesz igénybe. Az adatokat bizalmasan kezeljük és külső felekkel nem osztjuk meg. Kérem, válaszoljon az alábbi kérdésekre, hogy mennyire ért egyet az alábbi állításokkal (1- egyáltalán nem ért egyet; 5- teljes mértékben egyetért). Ha bármilyen kérdése felmerülne, kérjük a következő email címre írjon: agnes.somosi@uni-corvinus.hu. Válaszait elöre is köszönjük!

\section{Forgatókönyvek}

- 1. Szcenárió: A mobilszolgáltatód megszünteti a mobil csomagot, amire előfizettél., ami azt jelenti, hogy a jelenlegi előfizetésed feltételei a továbbiakban már nem lesznek elérhetőek. A mobilszolgáltató levélben értesít erről, amelyben új feltételeket ajánlanak számodra. A levél nem világos számodra, ezért úgy döntesz, hogy felhívod a mobilszolgáltatót. Többszöri hívás és hosszú várakozás után végre sikerül egy hozzáértő 
emberrel beszélned. Az ügyintéző barátságtalan és úgy tünik, hogy nem figyel oda az igényeidre, és a jelenlegi előfizetésednél összességében 10\%-kal drágább csomagot ajánl.

- 2. Szcenárió: A mobilszolgáltatód megszünteti a mobil csomagot, amire előfizettél., ami azt jelenti, hogy a jelenlegi előfizetésed feltételei a továbbiakban már nem lesznek elérhetőek. A mobilszolgáltató levélben értesít erről, amelyben új feltételeket ajánlanak számodra. A levél nem világos számodra, ezért úgy döntesz, hogy felhívod a mobilszolgáltatót. Többszöri hívás és hosszú várakozás után végre sikerül egy hozzáértő emberrel beszélned. Az ügyintéző barátságtalan és úgy tünik, hogy nem figyel oda az igényeidre, és a jelenlegi előfizetésednél összességében 10\%-kal kedvezőbb csomagot ajánl.

- 3. Szcenárió: A mobilszolgáltatód megszünteti a mobil csomagot, amire előfizettél., ami azt jelenti, hogy a jelenlegi előfizetésed feltételei a továbbiakban már nem lesznek elérhetőek. A mobilszolgáltató levélben értesít erről, amelyben új feltételeket ajánlanak számodra. A levél nem világos számodra, ezért úgy döntesz, hogy felhívod a mobilszolgáltatót. Többszöri hívás és hosszú várakozás után végre sikerül egy hozzáértő emberrel beszélned. Az ügyintéző barátságos és úgy tünik, hogy odafigyel az igényeidre, és a jelenlegi előfizetésednél összességében 10\%-kal drágább csomagot ajánl.

- 4. Szcenárió: A mobilszolgáltatód megszünteti a mobil csomagot, amire előfizettél., ami azt jelenti, hogy a jelenlegi előfizetésed feltételei a továbbiakban már nem lesznek elérhetőek. A mobilszolgáltató levélben értesít erről, amelyben új feltételeket ajánlanak számodra. A levél nem világos számodra, ezért úgy döntesz, hogy felhívod a mobilszolgáltatót. Többszöri hívás és hosszú várakozás után végre sikerül egy hozzáértő emberrel beszélned. Az ügyintéző barátságos és úgy tünik, hogy odafigyel az igényeidre, és a jelenlegi előfizetésednél összességében 10\%-kal kedvezőbb csomagot ajánl.

- 5. Szcenárió: A mobilszolgáltatód megszünteti a mobil csomagot, amire előfizettél., ami azt jelenti, hogy a jelenlegi elöfizetésed feltételei a továbbiakban már nem lesznek elérhetőek. A mobilszolgáltató levélben értesít erről, amelyben új feltételeket ajánlanak számodra. A levél nem világos számodra, de a szolgáltató szerencsére felhív, hogy tájékoztasson a változásokról. Az ügyintéző barátságtalan és úgy tünik, hogy nem figyel oda az igényeidre, és a jelenlegi előfizetésednél összességében 10\%-kal drágább csomagot ajánl.

- 6. Szcenárió: A mobilszolgáltatód megszünteti a mobil csomagot, amire elöfizettél., ami azt jelenti, hogy a jelenlegi előfizetésed feltételei a továbbiakban már nem lesznek elérhetőek. A mobilszolgáltató levélben értesít erről, amelyben új feltételeket ajánlanak 
számodra. A levél nem világos számodra, de a szolgáltató szerencsére felhív, hogy tájékoztasson a változásokról. Az ügyintéző barátságtalan és úgy tünik, hogy nem figyel oda az igényeidre, és a jelenlegi előfizetésednél összességében 10\%-kal kedvezőbb csomagot ajánl.

- 7. Szcenárió: A mobilszolgáltatód megszünteti a mobil csomagot, amire előfizettél., ami azt jelenti, hogy a jelenlegi előfizetésed feltételei a továbbiakban már nem lesznek elérhetőek. A mobilszolgáltató levélben értesít erröl, amelyben új feltételeket ajánlanak számodra. A levél nem világos számodra, de a szolgáltató szerencsére felhív, hogy tájékoztasson a változásokról. Az ügyintéző barátságos és úgy tünik, hogy odafigyel az igényeidre, és a jelenlegi előfizetésednél összességében 10\%-kal drágább csomagot ajánl.

- 8. Szcenárió: A mobilszolgáltatód megszünteti a mobil csomagot, amire előfizettél., ami azt jelenti, hogy a jelenlegi előfizetésed feltételei a továbbiakban már nem lesznek elérhetőek. A mobilszolgáltató levélben értesít erröl, amelyben új feltételeket ajánlanak számodra. A levél nem világos számodra, de a szolgáltató szerencsére felhív, hogy tájékoztasson a változásokról. Az ügyintéző barátságos és úgy tünik, hogy odafigyel az igényeidre, és a jelenlegi előfizetésednél összességében 10\%-kal kedvezőbb csomagot ajánl.

\section{Kérdések}

Q0 Kérem, válaszoljon az alábbi kérdésekre, hogy mennyire ért egyet az alábbi állításokkal (1- egyáltalán nem ért egyet; 5- teljes mértékben egyetért).

\begin{tabular}{|c|c|c|c|c|c|}
\hline & 1 & 2 & 3 & 4 & 5 \\
\hline Q1 Mindent figyelembe véve, a szolgáltató ajánlata & & & & & \\
\hline Q2 Nem kaptam meg, amit megérdemeltem volna. & & & & & \\
\hline $\begin{array}{l}\text { Q3 A körülményeket figyelembe véve, úgy érz } \\
\text { szolgáltató egy megfelelő ajánlatot adott számomra. }\end{array}$ & & & & & \\
\hline Q4 A szolgáltatáskivezetést időben kezelte a szolgál & & & & & \\
\hline $\begin{array}{l}\text { Q5 A szolgáltatáskivezetés helyzetének kezelése } \\
\text { meg olyan gyorsan, mint ahogyan az elvárható lett v }\end{array}$ & & & & & \\
\hline Q6 A szolgáltatáskivezetés folyamata ügyfélbarát vc & & & & & \\
\hline Q7 Udvariasan, tisztelettel bántak velem. & & & & & \\
\hline Q8 Úgy tünt, hogy az alkalmazottak odafigyelnek rá & & & & & \\
\hline Q9 Az alkalmazottaknak inkább negatív volt az attit & & & & & \\
\hline Q10 Úgy érzem, hogy gorombán bántak velem. & & & & & \\
\hline Q11 Úgy érzem, hogy ez az eset realisztikus. & & & & & \\
\hline Q12 Ez az eset megtörténhet a mindennapi életber & & & & & \\
\hline
\end{tabular}


Q1 Mi az Ön neme?

- $\quad$ Férfi (1)

- $\quad$ Nő (2)

Q2 Hány éves?

Q3 Mi az Ön legmagasabb befejezett iskolai végzettsége?

- Középiskolánál kevesebb (1)

- Középiskola (2)

- Föiskola, diploma nélkül (3)

- 2 éves felsőfokú tanulmányok után kapható diploma (USA) (4)

- $\quad$ B.Sc. diploma (5)

- M.Sc. diploma (6)

- Ph.D. (7)

Q4 Milyen országból származik?

Q5 Milyen nemzetiségü?

Q6 Milyen városban van a tartózkodási helye?

Q7 Mi a foglalkozása?

- Diák (1)

- Gyakornok (2)

- $\quad$ Kezdő szintü pozíció (3)

- Menedzser (4)

- $\quad$ Szenior menedzser (5)

- Igazgató (6)

- $\quad$ Elnök vagy CEO (7)

- Tulajdonos (8)

- Munkanélküli (9)

Q8 Milyen típusú szervezetnél dolgozik?

- For-profit (1)

- Non-profit (2)

- Kormányzat (3)

- $\quad$ Egészségügy (4)

- Oktatás (5)

- Egyéb (6) 
Q9 A munkaadójának összes müködési területét beleszámítva, összesen hány alkalmazottja van a szervezetnek?

- $1(1)$

- $\quad 2-9(2)$

- $10-24(3)$

- $\quad 25-99(4)$

- $100-499(5)$

- $500-999(6)$

- $1000-4999(7)$

- $5000+(8)$

Q10 Mi az Ön családi állapota?

- Egyedülálló (1)

- Kapcsolatban (2)

- Házas (3)

- $\quad$ Elvált (4)

Q11 Mi az Ön átlagos havi jövedelme (EUR)?

- $0-499(1)$

- $\quad 500-999(2)$

- $1000-1499(3)$

- $1500-1999$ (4)

- 2000-2499 (5)

- $2500-2999$ (6)

- $\quad 3000-3499$ (7)

- $\quad 3500-3999$ (8)

- $4000-4499$ (9)

- 4500-4999 (10)

- $\quad 5000+(11)$ 


\section{FÜGGELÉK: 3. TANULMÁNY: A HECKMAN- FÉLE KORREKCIÓS ELJARRÁS}

A Heckman- féle korrekciós eljárás a szelekciós torzítás kezelésében egyedi, amelyért James J. Heckman 2000-ben közgazdasági Nobel-emlékdíjat kapott (Nobelprize.org, 2017).

Heckman általános modelljében a bérek meghatározó tényezőit tárta fel úgy, hogy mivel a munkanélküliek esetében nem tudunk bérekre vonatkozó információt megfigyelni és a dolgozók nem véletlenszerü módon kerülnek kiválasztásra, a fellépő szelekciós torzítást kezelni kell (Heckman, 1979). A modell normális eloszlást feltételez.

Az első lépésben egy probit regressziót használ a munkába állás valószínüségének becslésére:

$\operatorname{Prob}(D=1 \mid Z)=\Phi\left(Z_{\gamma}\right)$,

ahol D egy Dummy változó, amely az alkalmazotti státuszt jelöli; a Z a magyarázó változók vektora, a $\gamma$ az ismeretlen változók vektora, a $\Phi$ pedig a normális eloszlás kumulatív eloszlás függvénye.

A második lépésben az önszelekciót azzal javítja, hogy az egyéni valószínüségekből számolva egy új, transzformatív magyarázó változóval egészíti ki a modellt:

$\omega^{*}=X \beta+u$,

ahol $\omega^{*}$ fejezi ki a bérszintet, amely csak a dolgozók esetében megfigyelt érték.

Ez alapján az elvárt munkabér szintje a dolgozók esetén:

$E[\omega \mid X, D=1]=X \beta+E[u \mid X, D=1]$.

Azzal a feltételezéssel kiegészítve, hogy a hibatagok többváltozós normális eloszlást követnek, a modell a következő:

$E[\omega \mid X, D=1]=X \beta+\rho \sigma_{u} \lambda\left(Z_{\gamma}\right)$,

ahol $\rho$ a munka $(\varepsilon)$ valószínűségét befolyásoló nem megfigyelt változók és a nem megfigyelt bér ajánlatokat $(\mathrm{u})$ befolyásoló tényezők közötti korreláció; $\sigma_{u}$ az u tapasztalati szórása és a $\lambda$ az inverz Mills-arány a $Z_{\gamma}$ pontban.

A bér egyenlet úgy is becsülhető, hogy a $\gamma$-t helyettesítjük az első lépésben becsült probit eredményekkel, amellyel a $\lambda$-t számítjuk ki, majd ezt kiegészítő változóként használjuk a második lépésben.

A módszertan hátrányai között említik a limited information maximum likelihood (LIML) becslés használatát, mivel a full information maximum likelihood (FIML) pontosabb becslést ad, viszont nehezebben alkalmazható (Puhani, 2000). Másik kritika a többváltozós normális eloszlás feltételezését kérdőjelezi meg, hiszen ha a minta ennek nem felel meg, 
akkor a becslések inkonzisztensek, amely különösen kis minták esetén okoz gondot (Goldberger, 1983).

\section{FÜGGELÉK: 3. TANULMÁNY: MULTIKOLLINEARITÁS VIZSGÁLATA- LINEÁRIS REGRESSZIÓS} MODELL

\begin{tabular}{|c|c|c|c|c|c|}
\hline Függő változó: CHURN & Koefficiens & Std. hiba & \multicolumn{2}{|l|}{$\mathbf{t}$} & $\mathbf{P}>$ \\
\hline TENURE & .0000579 & .0000105 & \multicolumn{2}{|c|}{5.50} & 0.00 \\
\hline CONTRACT & .0162866 & .0127253 & \multicolumn{2}{|c|}{1.28} & 0.2 \\
\hline CC_CALLS & .0050164 & .0016796 & \multicolumn{2}{|c|}{2.99} & 0.0 \\
\hline D_CC_CALLS & -.1039337 & .0118543 & \multicolumn{2}{|c|}{-8.77} & 0 . \\
\hline $\log$ MFDIFF & -.0104603 & .0081803 & \multicolumn{2}{|c|}{-1.28} & 0 \\
\hline BEFORE_USAGE_MINUTES & $1.17 \mathrm{e}-06$ & $2.64 \mathrm{e}-07$ & \multicolumn{2}{|c|}{4.41} & 0.0 \\
\hline NPS_CC & -.0049255 & .0055147 & \multicolumn{2}{|c|}{-0.89} & 0.3 \\
\hline D_NPS_CC & -.0654646 & .0361337 & \multicolumn{2}{|c|}{-1.81} & 0.0 \\
\hline \multirow[t]{11}{*}{ Konstans } & .862662 & .0593272 & \multicolumn{2}{|c|}{14.54} & 0 \\
\hline & Source & SS & \multicolumn{2}{|l|}{$\mathrm{df}$} & MS \\
\hline & \multirow{3}{*}{$\begin{array}{l}\text { Model } \\
\text { Residual } \\
\text { Total } \\
\end{array}$} & 73.3501915 & 14 & & \\
\hline & & 1160.73421 & 8705 & & 333 \\
\hline & & 1234.0844 & 8719 & & \\
\hline & Meg & figyelések szá & ma: & 872 & \\
\hline & $\mathrm{F}(1$ & $4,8705):$ & & 39.2 & \\
\hline & Prob & $>\mathrm{F}$ & & 0.0 & \\
\hline & $\mathrm{R}$-sq & quared: & & 0.0 & \\
\hline & Adj & R-squared: & & & \\
\hline & Roo & t MSE: & & .365 & \\
\hline
\end{tabular}

8. FÜGGELÉK: 3. TANULMÁNY: MULTIKOLLINEARITÁS VIZSGÁLATA - VIF

\begin{tabular}{lll} 
Változók & VIF & 1/VIF \\
\hline logMFDIFF & 1.04 & 0.963847 \\
TENURE & 2.69 & 0.371240 \\
CONTRACT & 2.61 & 0.383669 \\
BEFORE_USAGE_MINUTES & 1.06 & 0.939854 \\
NPS_CC & 3.93 & 0.254553 \\
D_NPS_CC & 4.33 & 0.231062 \\
CC_CALLS & 1.65 & 0.607051 \\
D_CC_CALLS & 1.65 & 0.607183 \\
\hline Átlag VIF & 2.37 \\
\hline \multicolumn{3}{c}{}
\end{tabular}




\section{F ÜGGELÉK: 3. TANULMÁNY: KORRELÁCIÓS MÁTRIX}

A 9. függelékben a következő rövidítéseket használjuk.:

1: CHURN

2: $\log$ MINDIFF

3: $\log$ MFDIFF

4: TENURE

5: CONTRACT

6: BEFORE_USAGE_MINUTES

7: CC_CALLS

8: D_CC_CALLS

9: NPS_CC

10: D_NPS_CC

\begin{tabular}{|c|c|c|c|c|c|c|c|c|c|c|}
\hline & 1 & 2 & 3 & 4 & 5 & 6 & 7 & 8 & 9 & 10 \\
\hline 1 & 1.0000 & & & & & & & & & \\
\hline 2 & 0.2871 & 1.0000 & & & & & & & & \\
\hline 3 & 0.0127 & 0.0791 & 1.0000 & & & & & & & \\
\hline 4 & -0.1165 & -0.1388 & 0.0528 & 1.0000 & & & & & & \\
\hline 5 & 0.0934 & 0.1245 & -0.1100 & -0.7739 & 1.0000 & & & & & \\
\hline 6 & 0.0166 & 0.1558 & 0.0162 & -0.1885 & 0.1791 & 1.0000 & & & & \\
\hline 7 & -0.1077 & -0.1180 & 0.0000 & 0.0201 & -0.0010 & 0.0201 & 1.0000 & & & \\
\hline 8 & 0.1524 & 0.1454 & 0.0176 & -0.1145 & 0.0583 & 0.0079 & -0.5432 & 1.0000 & & \\
\hline 9 & -0.0652 & -0.0708 & -0.0201 & 0.0448 & -0.0310 & 0.0123 & 0.1909 & -0.3643 & 1.0000 & \\
\hline 10 & 0.0854 & 0.0990 & 0.0058 & -0.0368 & 0.0201 & -0.0245 & -0.3757 & 0.4298 & -0.8476 & 1.0000 \\
\hline
\end{tabular}

10. FÜGGELÉK: 3. TANULMÁNY: $R^{2}$ BECSLÉSÉHEZ KÉSZITETT CSAK KONSTANST TARTALMAZÓ MODELL

Koefficiens $\quad$ Std. hiba $\quad$ z $\quad$ P $>$ Z

\begin{tabular}{|c|c|c|c|c|}
\hline \multicolumn{5}{|l|}{$\begin{array}{l}\text { 2. lépés: A nem lemorzsolódott ügyfelek } \\
\text { fogyasztói szokásainak elemzése } \\
\text { szolgáltatáskivezetés esetén }\end{array}$} \\
\hline logMINDIFF & & & & \\
\hline Konstans & -.7957479 & .0237301 & -33.53 & 0.000 \\
\hline \multicolumn{5}{|l|}{$\begin{array}{l}\text { 1. lépés: A lemorzsolódás becslése } \\
\text { szolgáltatáskivezetés esetén }\end{array}$} \\
\hline CHURN & .7544363 & .0361682 & 20.86 & 0.000 \\
\hline Konstans & .2562506 & .0330284 & 7.76 & 0.000 \\
\hline ath $\rho$ & .6577373 & .0310228 & 21.20 & 0.000 \\
\hline $\ln \sigma$ & .5881527 & .009946 & 59.13 & 0.000 \\
\hline
\end{tabular}




\begin{tabular}{llll}
\hline$\rho$ & .5768556 & .0206996 & \\
$\sigma$ & 1.800659 & .0179094 & \\
$\lambda$ & 1.03872 & .0444405 & \\
\hline LR-teszt független egyenletekre $(\rho=0)$ & chi2(1)= & 199.93 & \\
Megfigyelések száma (darab) & 10056 & & \\
Cenzorált megfigyelések száma (darab) & 1865 & \\
Nem cenzorált megfigyelések száma (darab) & 8191 & & \\
Wald $\chi^{2}(0)$ & - & & \\
Log-likelihood & -20529.41 & & \\
Prob $>\chi^{2}$ & - & \\
\hline
\end{tabular}

\section{Forrás: saját szerkesztés}

11. FÜGGELÉK: 3. TANULMÁNY: BACKWARD ELJÁRÁSSAL MANUÁLISAN KÉSZÍTETT MODELL UTOLSÓ VÁLTOZATA

Koefficiens Std. hiba $\quad \mathrm{z} \quad \mathrm{P}>\mathrm{Z}$

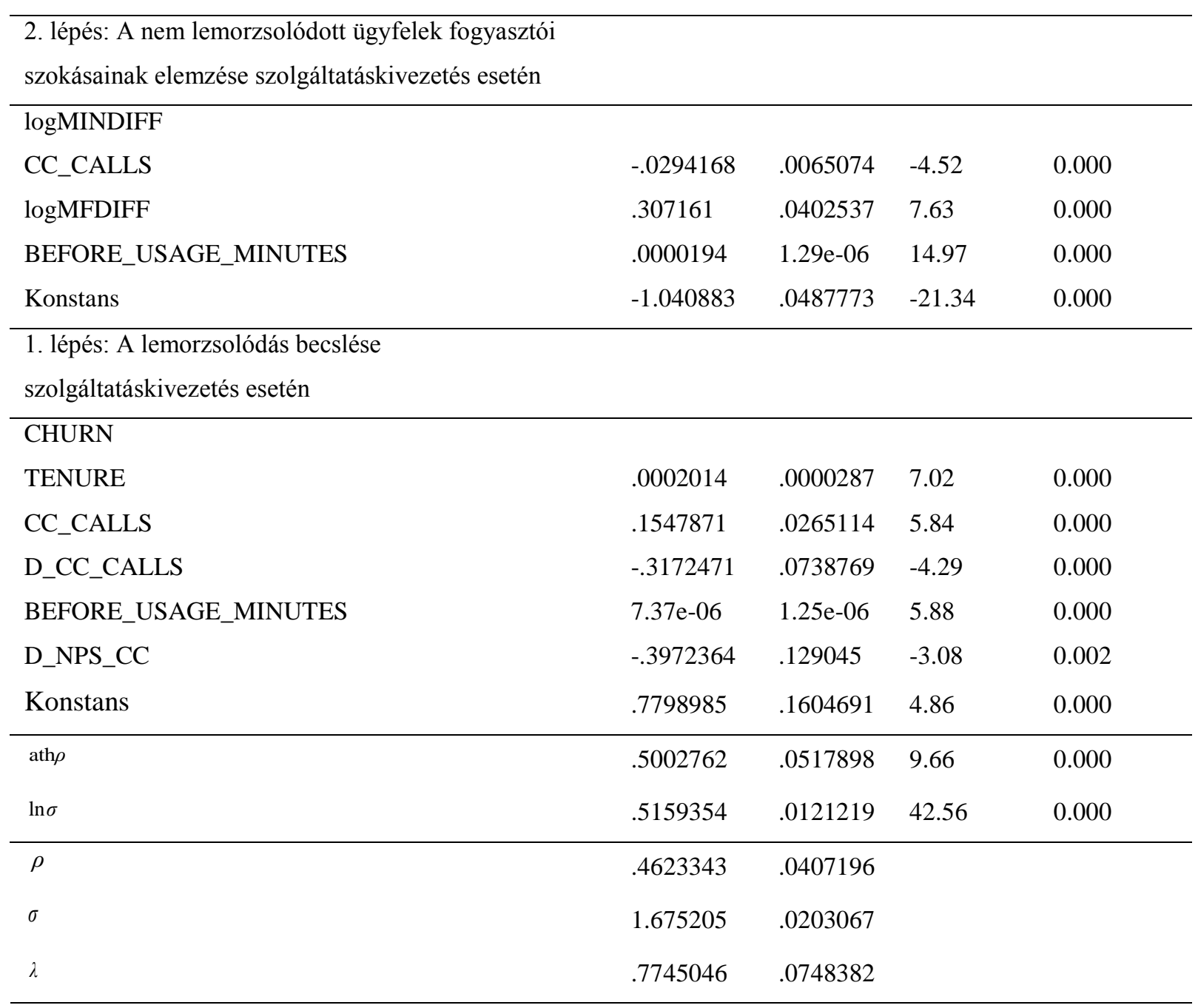

LR-teszt független egyenletekre $(\rho=0) \quad$ chi2 $(1)=$

$46.10 \quad 0.0000$

Megfigyelések száma (darab)

7755 


$\begin{array}{ll}\text { Cenzorált megfigyelések száma (darab) } & 1570 \\ \text { Nem cenzorált megfigyelések száma (darab) } & 6185 \\ \text { Wald } \chi^{2}(10) & 331.06 \\ \text { Log-likelihood } & -15318.87 \\ \text { Prob }>\chi^{2} & 0.0000\end{array}$

Forrás: saját szerkesztés 


\section{A SZERZŐ TÉMÁBAN MEGJELENT PUBLIKÁCIÓI}

\section{Folyóiratcikk:}

Angolul:

1. Somosi Á., Kolos K. (2017): The role of economic and psychological costs in service elimination. Budapest Management Review/Vezetéstudomány 48 (5), 14-23.

2. Somosi Á., Kolos K. (2016): Does Service Elimination Make Customers Less Satisfied?. Sefbis Journal 10, 49-53.

Magyarul:

3. Somosi Á. (2017): A lemorzsolódás és a fogyasztói magatartás vizsgálata szolgáltatás-kivezetés esetén Heckman-féle korrekciós eljárással. Statisztikai Szemle 95 (7), 744-764.

4. Somosi Á., Kolos K. (2017): A szolgáltatáskutatás tendenciái Magyarországon 1992-2016 között. Köz-Gazdaság 12 (5), 111-125.

5. Somosi Á. (2016): Az ügyfél használati szokásainak hatása a lemorzsolódásra szolgáltatás- kivezetés esetén. Gradus 3 (2), 208-213.

\section{Előadás és/vagy konferenciakiadványban megjelenő írás:}

Angolul:

6. Somosi Á., Kolos K. (2015): Customer Reactions to Service Elimination. In: Erzsébet Hetesi, Zsófia Vas (szerk.), New Ideas in a Changing World of Business Managament and Marketing, Szeged, Magyarország, 2015.03.19-2015.03.20. Szeged: University of Szeged, Doctoral School of Economics, 2015, ISBN:978963-306-312-5, pp. 24-34

7. Somosi Á, Kolos K (2014): The success-factors of service elimination. In: Continuous Innovation Network (szerk.), 15th International CINet Conference, Budapest, Magyarország, 2014.09.07-2014.09.09. Budapest: Continuous Innovation Network, 2014. ISBN: 978-90-77360-17-0, pp. 832-844.

Magyarul:

8. Somosi Á., Kolos K. (2016): Az ügyfél megtartás növelése szolgáltatás-kivezetés esetén. In: Fehér András, Kiss Virág Ágnes, Soós Mihály, Szakály Zoltán (szerk.), EMOK XXII. Országos konferencia 2016 Tanulmánykötet: Hitelesség és 
értékorientáció a marketingben, Debrecen, Magyarország, 2016.08.29-2016.08.31. Debrecen: Debreceni Egyetem Gazdaságtudományi Kar, 2016, ISBN:978-963-472850-4, pp. 460-468.

9. Somosi Á., Kolos K. (2015): A szolgáltatás-kivezetés a tarifacsomag és az ügyfél használati szokásainak figyelembe vételével. In: Bíró-Szigeti Szilvia, Petruska Ildikó, Szalkai Zsuzsanna, Kovács István, Magyar Mária (szerk.), Az Egyesület a Marketing Oktatásért és Kutatásért XXI. országos konferenciájának tanulmánykötete: Budapest, 2015. augusztus 27-28., Budapest, Magyarország, 2015.08.27-2015.08.28. Budapest: Budapesti Műszaki Egyetem, 2015, ISBN:978963-313-189-3, pp. 339-345.

10. Kolos K., Kenesei Zs., Somosi Á. (2014): Idősebb fogyasztók technológiai kompetenciáinak meghatározó tényezői. In: Hetesi Erzsébet, Révész B (szerk.), "Marketing megújulás": Marketing Oktatók Klubja 20. Konferenciája, Szeged, Magyarország, 2014.08.27-2014.08.29. Szeged: SZTE GTK, 2014. pp. 1-12.

\section{Könyvfejezet:}

Magyarul:

11. Somosi Á. (2007): A retroreklám története. In: Virányi Péter: Nem igaz, hogy a reklámtól lettem ilyen!. 228 p., Budapest: Gondolat Kiadó, 2007. ISBN:978-963693-079-0, pp. 170-179. 